\title{
Geology of the
}

\section{Hot Sulphur Springs}

Quadrangle, Grand

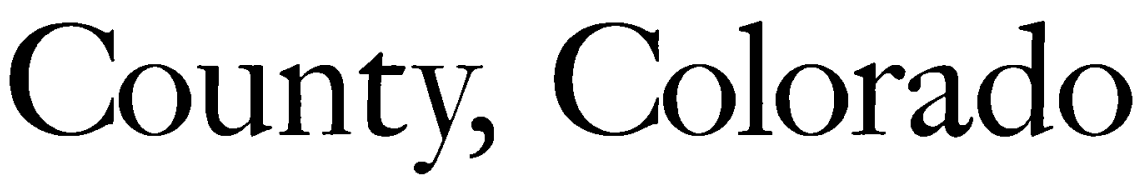

By GLEN A. IZETT

GEOLOGICAL SURVEY PROFESIONAL PAPER 586

General geology of part of Middle Park, Colo., with emphasis on the Troublesome Formation of Miocene age

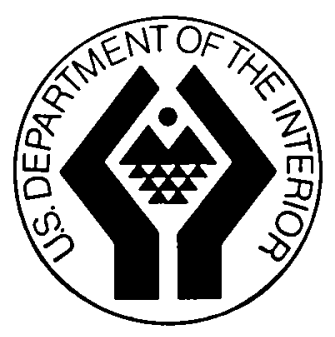

UNITED STATES GOVERNMENT PRINTING OFFICE, WASHINGTON : 1968 
UNITED STATES DEPARTMENT OF THE INTERIOR

STEWART L. UDALL, Secretary

GEOLOGICAL SURVEY

William T. Pecora, Director

Library of Congress catalog-card No. GS 68-234

For sale by the Superintendent of Documents, U.S. Government Printing Office Washington, D.C. 20402 


\section{CONTENTS}

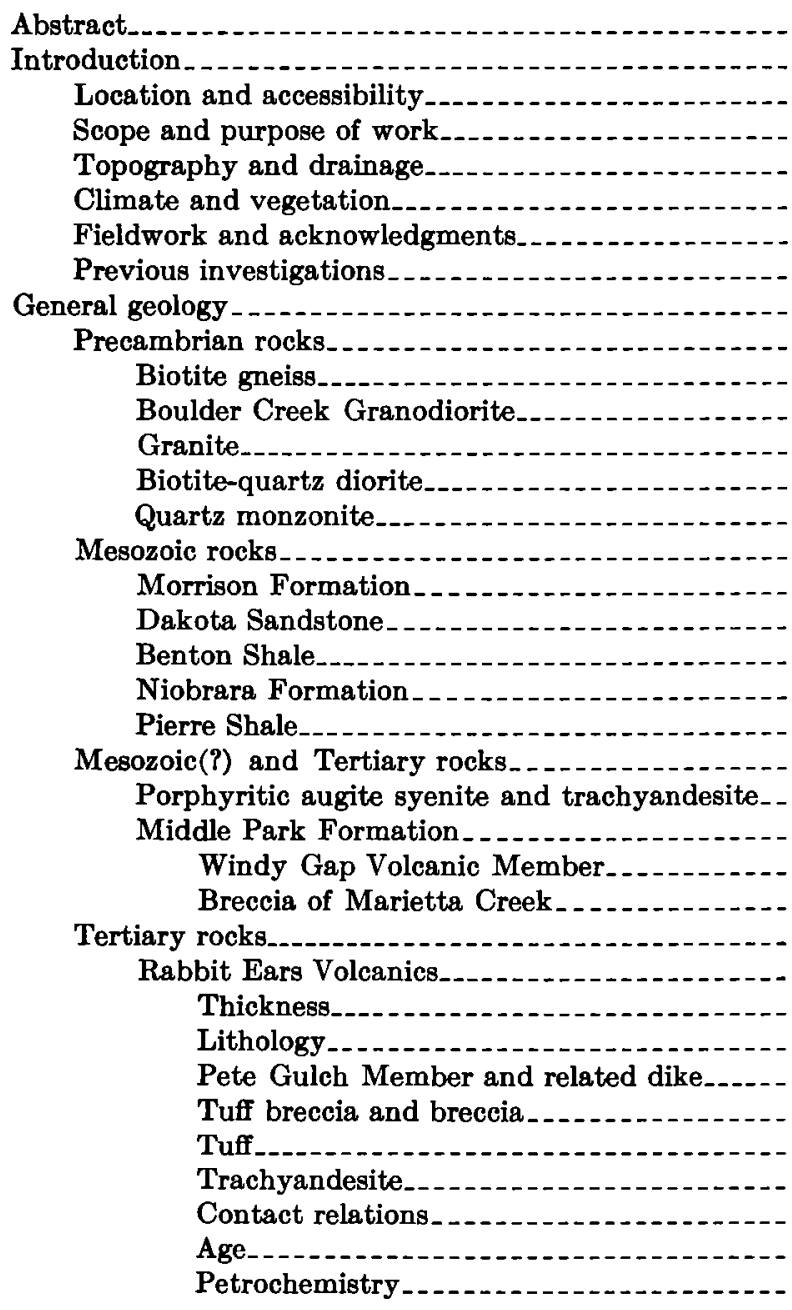




\section{CONTENTR}

\section{ILLUSTRATIONS}

Page

Plate 1. Geologic map of the Hot Sulphur Springs quadrangle, Grand County, Colo_..... In pocket

FIgURE 1. Index map showing location of Hot Sulphur Springs quadrangle.

2. Photomicrographs showing details of Precambrian rocks

3. Contour diagram of 300 lineations in biotite gneiss of Precambrian age

4-11. Photographs showing-

4. Superposed folding in hand sample of biotite gneiss.

5. Inclusions of Boulder Creek Granodiorite in quartz monzonite in Byers Canyon......

6. Dakota Sandstone and Morrison Formation at the east end of Byers Canyon

7. Breccia Spoon syncline and Elk Mountain._.

8. Large boulders of pink granitic rock of Precambrian age in Middle Park Formation

9. Middle Park Formation resting with angular unconformity on Dakota Sandstone

10. Windy Gap Volcanic Member of the Middle Park Formation at Windy Gap._...

11. Tuff breccia in the Rabbit Ears Volcanics at Corral Peaks.

12. Photomicrographs showing details of rocks in Rabbit Ears Volcanics

13. Photograph of breccia composed of quartz rhyolite welded tuff in Rabbit Ears Volcanics.

14. Silica-variation diagram of Tertiary volcanic rocks.

15. Photograph of reference section of the Troublesome Formation in lower Barger Gulch.

16. Photograph of Troublesome Formation at fossil locality 2

17. Photographs of vertebrate fossils in the Troublesome Formation

18. Correlation diagram showing an interpretation of time relations of Miocene rocks in Middle Park, Colo., and selected areas in Colorado, Nebraska, and Wyoming

19. Photograph of basalt dike cutting Rabbit Ears Volcanics at Corral Peaks.

20. Photograph of boulder conglomerate capping the south ridge of Little Gravel Mountain

21. Generalized structure map of the Hot Sulphur Springs quadrangle and surrounding areas. .........

22. View looking west at Corral Creek fault

23. View looking north at Mount Bross fault

24. Photograph of small-scale folds in the Windy Gap Member

25. Contour diagrams of joints

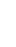

(2)

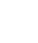

2

7

2

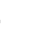

2

\section{8}

\section{TABLES}

TABLE 1. Generalized stratigraphic succession, Hot Sulphur Springs quadrangle, Grand County, Colo

2. Representative modes of rocks included in biotite gneiss

3. Representative modes of granite, quartz monzonite, and Boulder Creek Granodiorite

4. Representative modes of biotite-quartz diorite

5. Estimated percentages of minerals in some Cretaceous rocks

6. Fossils from the Pierre Shale

7. Some optical properties of Tertiary volcanic rocks

8. Chemical analyses and computed normative minerals of lavas and breccia fragments of middle and upper Tertiary volcanic rocks.

9. Fossil vertebrates from the Troublesome Formation..

10. Nonopaque heavy minerals from Mesozoic and Tertiary sedimentary rocks. 


\title{
GEOLOGY OF THE HOT SULPHUR SPRINGS QUADRANGLE, GRAND GOUNTY, COLORADO
}

\author{
By Guen A. IzetT
}

\begin{abstract}
The Hot Sulphur Springs quadrangle is an area of about 225 square miles in Grand County in north-central Colorado. The quadrangle is about 60 miles west of Denver, Colo., and lies in the central part of mountainous Middle Park athwart the Colorado River.

Rocks in the quadrangle include Precambrian crystalline rocks, Mesozoic and Tertiary sedimentary rocks, Mesozoic(?) and Tertiary intrusive igneous rocks, middle and upper Tertiary extrusive volcanic rocks, and Quaternary alluvial deposits and landslide and talus deposits. The oldest rocks in the area, which are Precambrian in age, are high-rank migmatitic biotite gneisses of metasedimentary origin and include small amounts of sillimanitic biotite gneiss, quartz-rich gneiss, and associated hornblendite. Planar and linear structures in the gneiss imply that the rocks were deformed at least twice during the Precambrian and that they include an older fold system that plunges southeast or northwest and a superposed younger fold system that plunges northeast or southwest. Siliceous plutonic rocks of Precambrian age younger than the metasedimentary gneisses include granite, quartz monzonite, Boulder Creek Granodiorite, and biotite-quartz diorite. The quartz monzonite is younger than the granodiorite and the biotite-quartz diorite, but the age of the granite relative to the other rocks and the age relationship between the Boulder Creek Granodiorite and the biotite-quartz diorite are not definitely established.
\end{abstract}

Mesozoic sedimentary rocks as much as 5,000 feet thick unconformably overlie the Precambrian rocks and are exposed in the southern part of the quadrangle along northwest-trending fault blocks and a narrow strip along the east margin of the quadrangle. These rocks include, from oldest to youngest, sandstone, mudstone, and minor limestone of the Morrison Formation of Late Jurassic age; conglomerate, sandstone, and siltstone of the Dakota Sandstone of Early Cretaceous age; shale, siltstone, limestone, and sandstone of the Benton Shale of Early and Late Cretaceous age; and shale, siltstone, and marly limestone of the Niobrara Formation and the Pierre Shale of Late Cretaceous age. The Morrison and the lower part of the Dakota form a lithogenetic unit that was deposited in a continental environment, but the upper part of the Dakota and the Benton, the Niobrara, and the Pierre were deposited in a marine or marginal marine environment. Mesozoic sedimentary and Precambrian crystalline rocks are truncated beneath a major unconformity at the base of the Middle Park Formation of Late Cretaceous and early Tertiary age.

The Middle Park Formation underlies about 160 square miles of the quadrangle and is made up of at least 6,000 feet of terrestrial arkosic basin-fill deposits that include in the lower part two distinctive andesitic volcaniclastic units - the Windy Gap Volcanic Member and the breccia of Marietta Creek. Andesitic rock fragments occur in largest amounts in the lower part of the formation, and Precambrian rock fragments are most abundant in the upper part of the formation.
Tuffaceous Miocene basin-fill sedimentary rocks of the Troublesome Formation that are about 400 feet thick mantle the older rocks and cover about 20 square miles in the southwestern part of the area. The formation is herein divided into two units: an orange-gray siltstone facies, and a varicolored conglomeratic claystone facies. These rocks locally contain diagnostic fossil mammalian bones, fresh-water clams and snails, and pollen and spores. Among the fossils in the lower part of the formation are remains of the oreodont Merycochoerus. Diagnostic fossils in the upper part of the formation are remains of the oreodont Brachycrus, the three-toed horse Merychippus, and the rodent Mesogaulus. These fossils permit correlation with well-known Miocene faunas in western Nebraska. The Troublesome Formation in the region contains beds 0-5 feet thick of nearly pure rhyolitic air-fall ash in at least 15 stratigraphic levels.

Upper Pliocene alluvial deposits that are about 100 feet thick cover a small divide in the southwest corner of the area and unconformably overlie the Troublesome Formation. Upper Tertiary boulder-bearing conglomerates provisionally assigned a Pliocene age cap ridges as high as 11,000 feet in the northeast corner of the quadrangle.

Deposits of terrace alluvium of Pleistocene and Recent age occur along the larger streams and their tributaries. Deposits of landslide and talus are scattered through the area.

A few Upper Cretaceous(?) and Tertiary intrusive igneous bodies of syenitic and basaltic composition are scattered in the area and form small plugs, dikes, and sills. Extrusive volcanic rocks of middle and late Tertiary age are divided into two formations, and they mantle uplands in the northern part of the quadrangle. The oldest formation, the Rabbit Ears Volcanics of Oligocene and Miocene(?) age, chiefly is made up of about 800 feet of breccia, tuff, and lavas of siliceous, intermediate, and mafic composition derived mainly from volcanic vents in the Rabbit Ears Range. Chemical analyses of the lavas and breccia fragments show that the rocks contain appreciable amounts of sodium and potassium oxides relative to amounts of calcium oxide and silica. The formation is thickest in the northern outcrops, but it thins to a featheredge just north of the Colorado River. A potassium-argon age of $33 \pm 3$ million years, or latest Oligocene, was determined on sanidine from a rhyolite welded tuff breccia fragment in the Rabbit Ears Volcanics. Thin lenticular olivine-bearing trachybasalt lavas at the base of the Rabbit Ears Volcanics are assigned to the Pete Gulch Member.

The youngest volcanic formation, the Grouse Mountain Basalt of Pliocene(?) age, is as much as 300 feet thick and includes several olivine-bearing basaltic lava flows and associated tuffaceous sedimentary rocks. Locally, the Grouse Mountain is separated from the underlying volcanic rocks of the Rabbit Ears by the Troublesome Formation.

The quadrangle lies in the southern part of a large northtrending open syncline, North-Middle Park basin, which is one of the larger structural blocks in north-central Colorado. In 
much of the quadrangle the structure in the rocks is fairly simple and consists of gentle northwest-trending folds in Tertiary sedimentary rocks of the Middle Park Formation. In the southern part of the quadrangle the structure is more complex, and there several west-northwest-trending faults of at least 1,500 feet displacement expose thin sequences of northeast-dipping Mesozoic sedimentary rocks in fault-block pattern beneath a thin cover of the Troublesome and Middle Park Formations and upper Cenozoic alluvial deposits. No Paleozoic rocks occur in the mapped area, and, accordingly, the timing and recognition of structures of Paleozoic age cannot be established. Upper Mesozoic and Tertiary sedimentary rocks record two stages of Laramide and one stage of post-Laramide tectonism. An early stage of Laramide tectonism of probable latest Cretaceous time occurred before deposition of the Middle Park Formation and consisted of large-scale reverse faulting and broad folding. Prominent structures associated with this tectonism are the westnorthwest-trending Corral Creek and Parshall faults. As a result of this tectonism a large part of the tectonic framework of NorthMiddle Park was established, and a fairly rugged topography locally was developed in the mapped area. A later stage of Laramide tectonism of probable late Eocene age occurred after the deposition of the Middle Park Formation and consisted of broad folding and thrust faulting. Folds and faults associated with this period of tectonism are the north- to northwesttrending Breccia Spoon syncline, Blue Ridge anticline, Granby anticline, and a branch of the Vasquez overthrust, here called the Mount Bross fault. A post-Laramide period of tectonism of probable early Pliocene age is recorded in the area by faults that cut the middle Tertiary volcanic rocks, and this is also recorded to the west in the Kremmling quadrangle by a northtrending fault system that cuts the Troublesome Formation of Miocene age. The fault system includes a large north-trending fault that separates vertical beds in the Pierre Shale from vertical beds in the Troublesome Formation.

The chief purpose of the work was to evaluate the coal-bearing potential of the Middle Park Formation in the area. Two thin impure lignitic coal beds were traced for short distances in the lower part of the formation, but they are not commercially important. In 1957, two wells for oil and gas were drilled in the area on the upthrown side of the Mount Bross fault, but neither was successful. Gravel useful for road metal or concrete aggregate is available at several places in the area. Some rocks of the Rabbit Ears Volcanics may be useful for light-weight aggregate. Placer gold is reported to occur in alluvial deposits along Willow Creek and its eastern tributaries in the northeastern part of the area.

\section{INTRODUCT ION
LOCATION AND ACCESSIBILIT Y}

The Hot Sulphur Springs 15-minute quadrangle is an area of about 225 square miles in the central part of Grand County, Colo., in Middle Park and is bounded by lat $40^{\circ} 00^{\prime}$ and $40^{\circ} 15^{\prime} \mathrm{N}$. and by long $106^{\circ} 00^{\prime}$ and $106^{\circ} 15^{\prime} \mathrm{W}$. (fig. 1 ). The quadrangle is about 60 airline miles west-northwest of Denver, Colo., and contains the town of Hot Sulphur Springs, the county seat of Grand County; the town takes its name from springs that issue from Cretaceous and Tertiary rocks on the north side of the Colorado River at the head of Byers Canyon. The springs, or "Hot Springs" as they were known to the early settlers, are a prominent landmark in Middle Park. Parshall, Colo., about 4 airline miles west of Hot Sulphur Springs, is the only other settlement in the quadrangle.

Most areas in the quadrangle are accessible by roads or jeep trails. U.S. Highway 40, which connects Hot Sulphur Springs, Parshall, Kremmling, and Granby in Middle Park, and the Denver and Rio Grande Western Railroad follow the Colorado River valley and cross the southern part of the quadrangle. State Highway 125 crosses the northeastern part of the quadrangle, traverses Willow Creek Pass, and connects Middle and North Parks. Good gravel roads leave U.S. Highway 40 at Hot Sulphur Springs (Cottonwood Pass road) and at Parshall (Williams Fork road) and give access to the area south of the Colorado River. A gravel road leaves U.S. Highway 40 at Rock Creek, and from this gravel road several unimproved roads and jeep trails give access to large areas north of the Colorado River. Elsewhere, unimproved dirt roads leave U.S. Highway 40 to the north and south and provide access to other parts of the quadrangle. In the summer of 1964 many logging roads were being built in the northern part of the quadrangle to give access to remote parts of the area.

\section{SCOPE AND PURPOSE OF WORK}

The quadrangle was mapped as part of the U.S. Geological Survey program of classifying and evaluating lands in the Public Domain. Mineral rights for coal had been retained in parts or all of Tps. 2 and 3 N., Rs. 77,78 , and $79 \mathrm{~W}$. These areas are in part underlain by sedimentary rocks of Late Cretaceous(?) and early Tertiary age (Middle Park Formation), and in North Park these rocks are called the Coalmont Formation and contain coal. The chief purpose of the work was to map and study any coal beds found and to make a detailed geologic map that can be used as part of a geological atlas of the United States.

\section{TOPOGRAPHY AND DRAINAGE}

The quadrangle lies in the central part of Middle Park, a large topographic depression that is bounded on the south and east by the Front Range, on the north by the Rabbit Ears Range, and on the west by the Park Range. Unlike the other large intermontane basins or parks in Colorado (South and North Parks) that mainly have broad rolling grass-covered gentle floors, Middle Park is mountainous and locally heavily forested. It is best recognized as a park when viewed from several thousand feet above the land surface. Maximum relief in the quadrangle is about 4,000 feet; altitudes range from 11,419 feet on Elk Mountain to about 7,400 feet along the Colorado River valley at the west edge of the quadrangle.

Much of the area is underlain by alternating coarse sandstones and mudstones of the Middle Park Forma- 


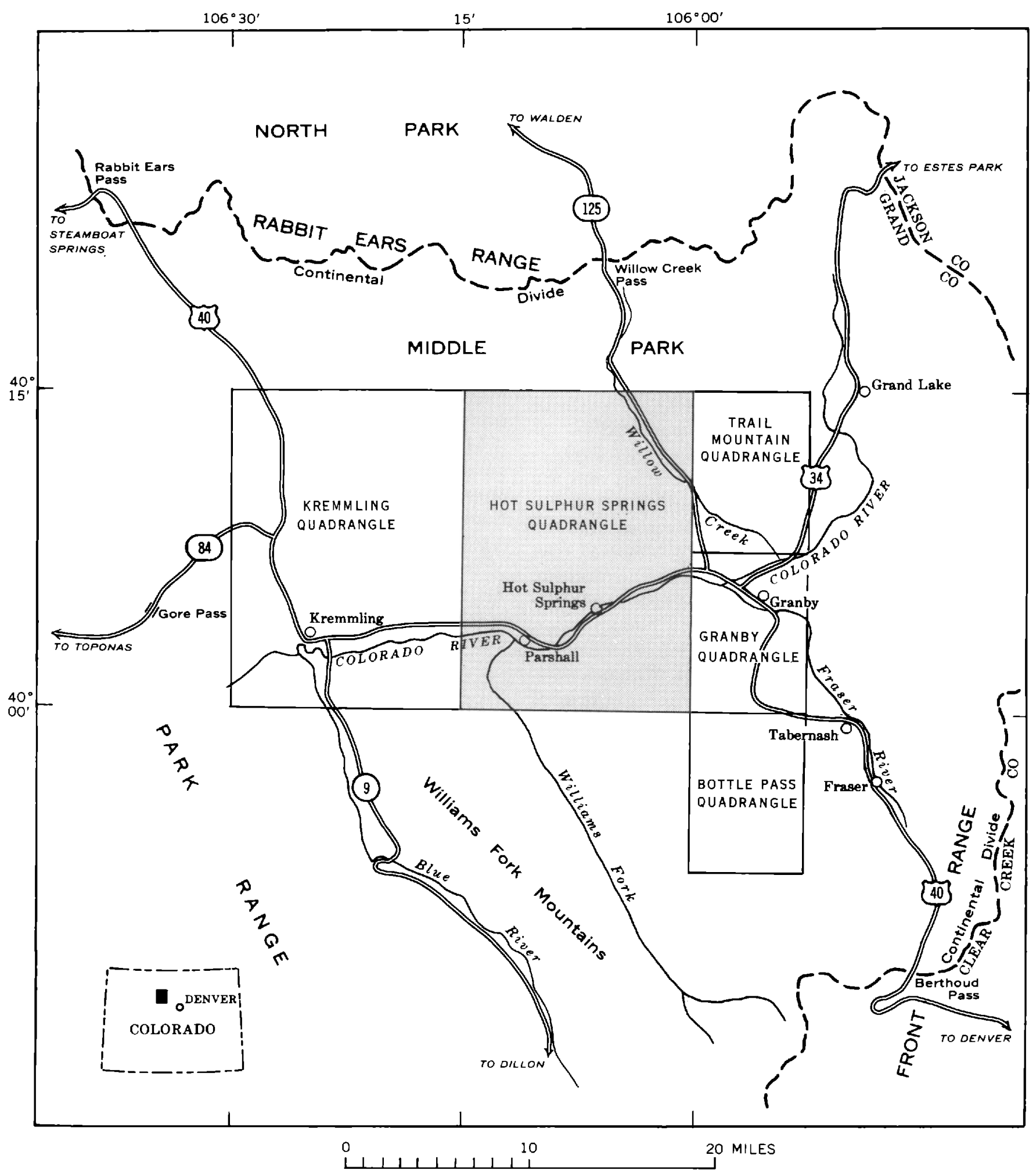

Fradre 1.-Location of Hot Sulphur Springs quadrangle. 
tion that form cliffs and ledges separated by slopes. In the uplands north of the Colorado River, effusive volcanic rocks form either broad gently dipping surfaces as at Elk and Grouse Mountains or fairly ragged steep slopes and peaks as at Corral Peaks. Rivers cut either tight $V$-shaped canyons where they flow across crystalline rocks of Precambrian age or fairly wide flat-floored valleys where they flow across sedimentary rocks of Mesozoic and Tertiary age. Hogbacks or cuestas are formed at the east edge of Byers Canyon and below the Williams Fork Reservoir where rivers cut through dipping Mesozoic sedimentary rocks.

The quadrangle is drained by small tributaries that How south or north into the west-flowing master stream in the area, the Colorado River. The Williams Fork, which is the largest tributary of the Colorado in the quadrangle, has its headwaters to the south in the Front Range and joins the Colorado River at Parshall. The northeastern part of the quadrangle is drained by Willow Creek and its tributaries, and the northwestern part, by East Fork Troublesome Creek. Willow Creek enters the Colorado River east of the quadrangle near Granby, Colo., and Troublesome Creek enters the Colorado a few miles west of the quadrangle.

The major streams in the area, the Colorado and the Williams Fork, probably inherited their present position by superposition. Good examples of superposition of streams are found in the region, as below Williams Fork Reservoir along the Williams Fork, on the lower reaches of Corral Creek, and at Byers Canyon along the Colorado River. During the late Tertiary, soft tuffaceous sedimentary rocks of the Troublesome Formation of Miocene age covered much of the area west of Byers Canyon, and the drainage pattern of the ancestral Colorado River and its tributaries the Williams Fork and Corral Creek was probably established on the eroded surface of the Troublesome Formation. Uplift in the area in Pliocene time superposed the drainage pattern on the structurally deformed older rocks that underlay the Troublesome. In the area below Williams Fork Reservoir the northward-flowing Williams Fork cut through the Troublesome and exposed a preTroublesome erosion surface in a short canyon that lies athwart the structural grain of the area. If superposition had not been operating, the Williams Fork could have cut northwest across the soft beds of the Troublesome to its confluence with the Colorado River near the west boundary of the quadrangle. Outcrops at Byers Canyon show that the Colorado River has cut through the Middle Park Formation and has cut a narrow gorge in the Precambrian rocks. The drainage pattern formed on the Middle Park Formation has been superposed onto the underlying Precambrian rocks. The west-flowing Colorado River crosses a large north- trending fold in Upper Cretaceous and lower Tertiary rocks (Middle Park Formation) in the eastern part of the area. The ancestral Colorado River was probably superposed from a surface formed on upper Tertiary rocks onto the deformed older rocks.

\section{CLIMATE AND VEGETATION}

The climate in the quadrangle is mild in the summer and cold in the winter. The nearest weather station is about 18 miles southeast of the quadrangle at Fraser, Colo. Weather data compiled by the U.S. Weather Bureau (1933) for the period 1889-1930 show that the annual precipitation averages about 21 inches, and most precipitation occurs in April and July. The average winter temperature is about $13^{\circ} \mathrm{F}$., and the average summer temperature is about $51^{\circ} \mathrm{F}$. The average minimum temperature in January is about $-4^{\circ} \mathrm{F}$., and the a verage maximum temperature in July is about $71^{\circ} \mathrm{F}$.

Much of the north half and southeastern part of the quadrangle is in the Arapaho National Forest. These areas are covered by thick stands of lodgepole pine, Engelmann spruce, alpine fir, aspen, and a few scattered Douglas-fir and limber pine. The thickest stands of evergreens grow on northward-facing slopes. In the south half and in the southwestern part of the quadrangle the surface is covered mainly by sage, range grasses, and, along water courses, willows.

\section{FIELDWORK AND ACKNOWLEDGMENTS}

Fieldwork was done in the summer months of 196164. During this time A. A. Wanek, D. L. Hoover, and C. S. V. Barclay of the U.S. Geological Survey mapped parts of the quadrangle; the geologic map, plate 1, shows the area each geologist mapped. The writer was ably assisted in the field by R. R. Cunningham and W. H. Laraway in 1963 and by A. M. Thompson in 1964.

During the fieldwork W. J. Hail, Jr., D. M. Kinney, and R. B. Taylor of the U.S. Geological Survey mapped areas near the Hot Sulphur Springs quadrangle, and field conferences were helpful in discussing mutual problems. G. E. Lewis of the U.S. Geological Survey aided in the paleontologic-stratigraphic study of the Troublesome Formation, and his wide knowledge of Miocene time-stratigraphic correlation problems in the Western Interior was invaluable. R. W. O'Donnell of the U.S. Geological Survey ably assisted G. E. Lewis and the writer in the field collecting fossil vertebrates. W. A. Cobban, N. M. Denson, G. N. Pipiringos, G. R. Scott, and R. E. Wilcox, all of the U.S. Geological Survey, visited the writer in the field and helped with stratigraphic problems. The writer appreciates the cooperation of Peter Robinson of the University of Colorado who was invited by G. E. Lewis and the 
writer to quarry, screen, and study the mammalian microfossils of the Tertiary rocks. Robinson kindly supplied faunal lists of the mammalian vertebrates that he collected in the Troublesome Formation. The writer is indebted to the residents in the area, who were cooperative and helpful in every way.

\section{PREVIOUS INVESTIGATIONS}

One of the earliest notes on the geology of Middle Park was made by F. V. Hayden (1869) after a brief trip to the park in 1869. The areal geology of the quadrangle was first described as a result of a regional study of Middle Park, Colo., by A. R. Marvine (1874), geologist in charge of the Middle Park Division of the Hayden Survey. Other early geologists who described certain aspects of the geology in the Hot Sulphur Springs area include Clark (1891), Cross (1892), Lakes (1905), and Cockerell (1908). More recent descriptions of the surface geology in or adjacent to the area were written by Lovering (1930), Lovering and Goddard (1950), Sanders (1957), Shearer (1957), and Tweto (1957). Certain aspects of the economic geology of the area have been described by Austin (1957), Malan (1957), and Vine (1957). Ground-water resources of Middle Park have been described by P. T. Voegeli (1965). Several thesis studies have been made in the area, but none of the maps or reports have been published. Preliminary geologic maps (scale $1: 24,000$ ) of parts of the quadrangle were made by Wanek (1963), Izett and Hoover (1963), Izett and Barclay (1964), and Izett (1965), and short notes on the geology of the area were made by Izett and Lewis (1963), Izett, Taylor, and Hoover (1963), and Izett (1966).

\section{GENERAL GEOLOGY}

Rocks that range in age from Precambrian to Recent are exposed in the area, and the areal distribution of these rocks is shown on plate 1 . A generalized stratigraphic succession of the rocks in the quadrangle is given in table 1. Precambrian crystalline rocks underlie approximately 10 square miles in the southern part of the quadrangle, and they form three west-northwesttrending ridges and a few small isolated knolls. The southern and middle ridges are moderately sharp topographic features, but the northern ridge is gentle; the three ridges are separated by valley- and hogbackforming Mesozoic and Cenozoic rocks and by westnorthwest-trending reverse faults. The southern ridge is composed of intricately folded moderately high rank migmatitic metasedimentary gneisses that have been retrograded. The gneisses mainly consist of quartz, plagioclase, biotite, and muscovite and have been mapped as biotite gneiss. Associated with the biotite gneiss are a few thin discontinuous layers of sillimanitic biotite gneiss, hornblendite, and quartz-rich gneiss, but owing to their small size, these units are not shown on the map. Planar and linear structures in the gneiss indicate that the southern ridge may be underlain by older southeast- or northwest-plunging closed folds and superposed younger northeast-plunging open folds. The middle ridge is mainly quartz monzonite and subordinate small plutons of biotite-quartz diorite. The quartz monzonite is medium- to coarse-grained granitic rock contaminated by layers and lenses of biotite gneiss or schist and irregular masses and inclusions of foliated granodiorite. The northern ridge is mediumgrained granite that resembles silicic parts of the Boulder Creek Granodiorite of the Front Range in Colorado. Small outcrops of Boulder Creek Granodiorite were mapped near Williams Fork Reservoir.

Sedimentary rocks of Mesozoic age as much as 5,000 feet thick underlie about 11 square miles in the southern part of the quadrangle and lie along three northwesttrending belts and in a narrow strip along the east margin of the area. The three belts are bounded on the northeast by reverse faults of large displacement that probably dip northeast. The Mesozoic rocks exposed along these fault blocks include, from oldest to youngest, sandstone, mudstone, and limestone of the Morrison Formation of Late Jurassic age; sandstone, siltstone, and conglomerate of the Dakota Sandstone of Early Cretaceous age; shale, siltstone, sandstone, and limestone of the Benton Shale of Early and Late Cretaceous age; and shale, siltstone, and marly limestone of the Niobrara Formation and the Pierre Shale of Late Cretaceous age. The Morrison Formation and the lower part of the Dakota Sandstone form a lithogenetic unit that was deposited in a continental environment. The upper part of the Dakota and the Benton, the Niobrara, and the Pierre were deposited in a marginal marine or marine environment.

Mesozoic sedimentary and Precambrian crystalline rocks are truncated beneath a pronounced unconformity at the base of the Middle Park Formation of Late Cretaceous(?) and early Tertiary age. The formation is made up of at least 6,000 feet of terrestrial basin-fill deposits that include arkosic detrital rocks interlayered in the lower part with two distinctive volcanic units, the Windy Gap Volcanic Member and the breccia of Marietta Creek. Tuffaceous middle Tertiary basin-fill deposits, about 400 feet thick, mantle the older rocks in the area and make up the Troublesome Formation. Upper Tertiary rocks cap ridges in the northeast corner of the quadrangle and cover a divide in the southeast corner. Deposits of terrace alluvium of Pleistocene and Recent age are along the larger rivers and some of their tributaries.

Extrusive volcanic rocks of middle and late Tertiary age crop out in the northern part of the quadrangle 
GEOLOGY OF THE HOT SULPHUR SPRINGS QUADRANGLE, GRAND COUNTY, COLORADO

TABLE 1.-Generalized stratigraphic succession, Hot Sulphur Springs quadrangle, Grand County, Colo.

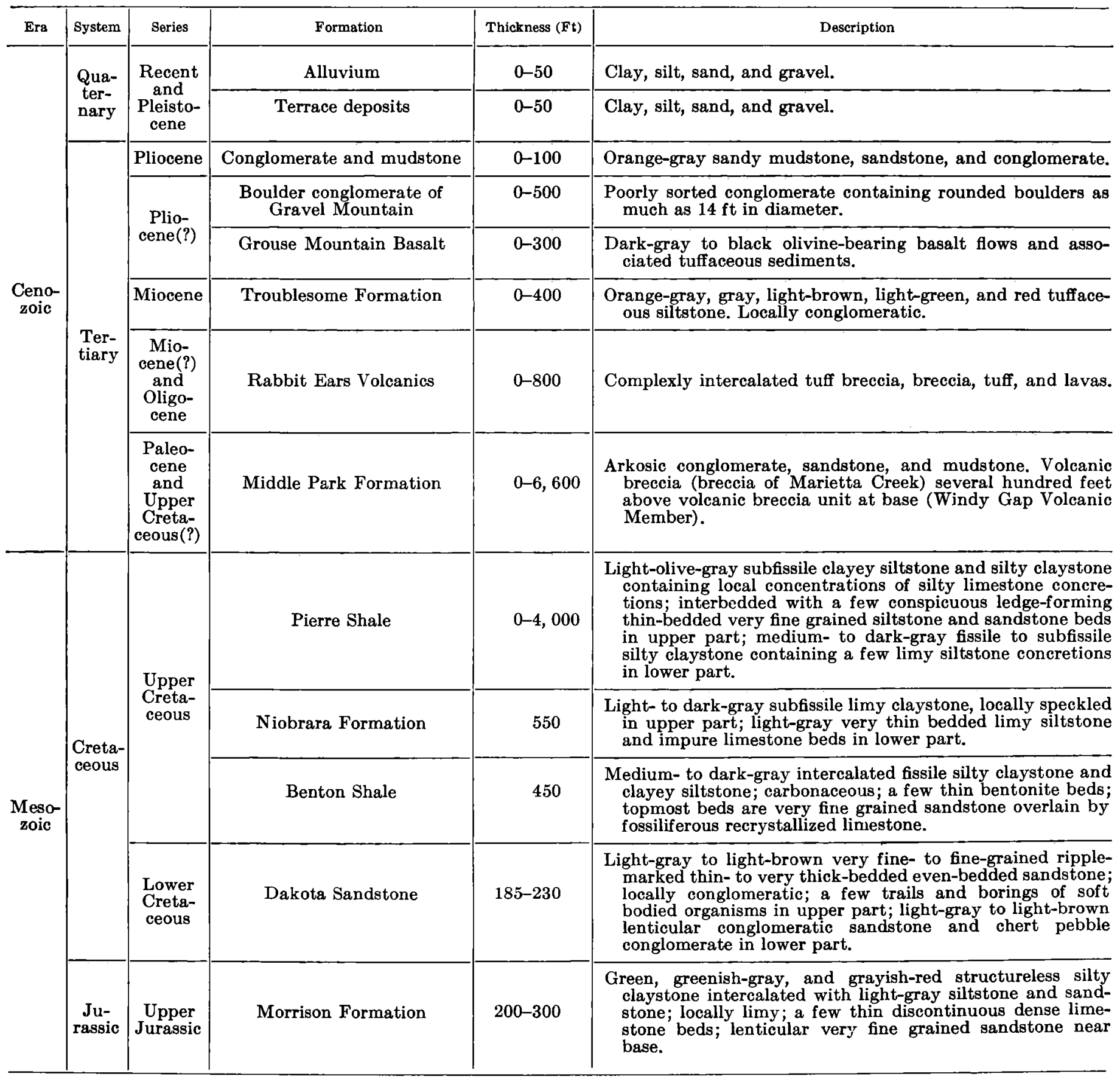

and make up the Rabbit Ears Volcanics and the Grouse Mountain Basalt. A few syenite, andesitic, trachyandesitic, and basaltic dikes and plugs are scattered through the area.

The chief structures in the area are north- and northwest-trending reverse faults of Laramide age. Locally, tight overturned synclines are adjacent to and parallel some of the larger faults. Twolarge broad open folds, the Breccia Spoon syncline and the Blue Ridge anticline, underlie large areas in the quadrangle.

\section{PRECAMBRIAN ROCKS}

\section{BIOTITE GNEISS}

Rocks mapped as biotite gneiss form a layered sequence of moderately high rank migmatitic metasedimentary gneisses that resemble rocks that have been called injection gneiss. The unit mapped as biotite gneiss in the area includes minor amounts of other rock types. A stratigraphic succession among the layers that make up the gneiss could not be determined owing to lack of marker beds and to discontinuous outcrops. 
Biotite gneiss is the oldest Precambrian rock unit exposed in the area, and it crops out along a westnorthwest-trending ridge north of Williams Fork Reservoir in the southern part of the quadrangle. A few other small outcrops of biotite gneiss were found south and east of Williams Fork Reservoir and at the northeast end of Byers Canyon. Because of their small size, the outcrops at the northeast end of Byers Canyon were not mapped. In the Williams Fork Reservoir area south of the ridge, biotite gneiss probably lies at shallow depths beneath Miocene intermontane basin-fill deposits of the Troublesome Formation and Quaternary terrace deposits. South of the area in the adjoining Ute Peak quadrangle, gneisses similar to the biotite gneiss unit were mapped and assigned to the Idaho Springs Formation by Lovering and Goddard (1950, pl. 1). Extension of the formal nomenclature for these rocks into this area at this time would be premature and should await completion of studies in progress in the Front Range.

Biotite gneiss in the quadrangle is migmatitic, and a fairly complete gradation occurs between rocks mapped as biotite gneiss and those that some geologists call migmatite. Outcrops along the south half of Cedar Ridge are slightly migmatitic, and they consist chiefly of thin alternating light-gray quartzo-feldspathic and dark-gray biotite-rich bands containing subordinate layers and lenses of granitic rock. Outcrops along the north half of Cedar Ridge are more widely migmatized than those along the south half. Hand samples of biotite gneiss in the quadrangle consist chiefly of thin alternating light-gray quartzo-feldspathic and darkgray biotite-rich bands. In most places, the quartzofeldspathic bands, which are generally less than 1 inch thick, pinch on flanks and swell on crests and troughs of small folds. The quartzo-feldspathic bands contain a few percent of biotite and muscovite flakes that are generally oriented parallel to the biotite-rich bands and to the compositional layering of the gneiss. The gneiss locally contains quartz augens as much as 1 foot thick. The texture of the biotite gneiss is generally lepidoblastic and ranges from fine to coarse grained.

Associated with the biotite gneiss are thin discontinuous layers of sillimanitic gneiss and quartz-rich gneiss. Although sillimanite is not megascopically identifiable in most samples of the biotite gneiss, trace amounts were usually seen under the microscope. Along the east side of Williams Fork Reservoir in sec. 26, T. 1 N., R. 79 W., however, a few conspicuous lenticular masses and many small rod-shaped aggregates of sillimanite occur in the biotite gneiss. Thin layers of even-grained poorly foliated quartz-rich gneiss are scattered through the area, and modes of this rock type are shown in table 2. Quartz-feldspar-mica pegma-
TABLE 2.-Representative modes (volume percent) of rocks included in biotite gneiss [Tr., trace]

\begin{tabular}{|c|c|c|c|c|c|c|c|}
\hline \multirow{2}{*}{ Mineral } & \multicolumn{7}{|c|}{ Sample } \\
\hline & G762 & G962 & G1262 & Q1362 & $\mathrm{G}_{16 \mathrm{~B}}$ & G1862 & G1562 \\
\hline $\begin{array}{l}\text { Quartz } \\
\text { Oligoclase- } \\
\text { Biotite } \\
\text { Muscovite- }\end{array}$ & $\begin{array}{r}36 \\
34 \\
20 \\
9\end{array}$ & $\begin{array}{r}33 \\
51 \\
12 \\
2\end{array}$ & $\begin{array}{l}36 \\
14 \\
17 \\
30\end{array}$ & $\begin{array}{r}31 \\
40 \\
19 \\
6\end{array}$ & $\begin{array}{l}51 \\
24 \\
12 \\
11\end{array}$ & $\begin{array}{l}55 \\
27 \\
17\end{array}$ & $\begin{array}{r}8 \\
5 \\
\mathrm{Tr} .\end{array}$ \\
\hline 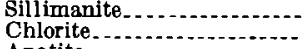 & $\operatorname{Tr}_{\mathrm{Tr}}$ & & Tr. & Tr. & & & Tr. \\
\hline $\begin{array}{l}\text { Apatite } \\
\text { Magnetite....... }\end{array}$ & Tr. & $\begin{array}{l}\text { Tr. } \\
\text { Tr. }\end{array}$ & $\begin{array}{l}\text { Tr. } \\
\text { Tr. }\end{array}$ & $\begin{array}{l}\text { Tr. } \\
\text { Tr. }\end{array}$ & $\begin{array}{l}\text { Tr. } \\
\text { Tr. }\end{array}$ & $\begin{array}{l}\text { Tr. } \\
\text { Tr. }\end{array}$ & $\mathrm{Tr}$. \\
\hline Epidote.... & Tr. & Tr. & T & Tr. & Tr. & $\mathrm{Tr}$. & \\
\hline $\begin{array}{l}\text { Hornblende. } \\
\text { Sphene..... }\end{array}$ & & & & & & & 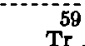 \\
\hline $\begin{array}{l}\text { Sphene- } \\
\text { Sericite } \\
\text { Clay... }\end{array}$ & & & & & & & $\begin{array}{l}\operatorname{Tr} \\
\operatorname{Tr}\end{array}$ \\
\hline Clay....... & & & & & & & $\mathrm{Tr}$. \\
\hline
\end{tabular}

SAMPLE LOCALITY

G762. Sillimanitic biotite gneiss from the NE1/4 sec. 30, T. 1 N., R. $78 \mathrm{~W}$

G962. Biotite gneiss from along road to Williams Fork Reservoir in sec. $25, T .1 \mathrm{~N}$ G1262. R. 79 W.

G136. G1362. Biotite gneiss from the NW cor sec. 25, T.1 N. R. $79 \mathrm{~W}$.

G16B. Quartz-rich gneiss from sec. 21,T.1 N., R. 79 W.

G1862. Quartz-rich gneiss from sec. 22, T. 1 N., R. 79

tites and aplite that show concordant and crosscutting relations with the biotite gneiss are fairly widespread. A few thin lenticular concordant layers of quartz monzonite and granodiorite were seen within the biotite gneiss, but owing to their small size they were not mapped. The quartz monzonite layers resemble the quartz monzonite of Byers Canyon, and the granodiorite resembles the Boulder Creek Granodiorite. A small area of pink to red cataclastic gneissic rock was mapped in the NW/4 sec. 4, T. 1 N., R. 79 W. The relation of the rock to the biotite gneiss south of the Colorado River is not as yet known, and the rock is classed with the biotite gneiss.

A few hornblendite layers and lenses that seem to be concordant with the biotite gneiss and that are less than 5 feet thick were traced along the outcrop for short distances in secs. 21 and 26, T. 1 N., R. 79 W. These layers are too thin and discontinuous to show on the map (pl. 1). The hornblendite is a dark-gray to black fine- to medium-grained rock that is locally rich in epidote. In thin section, blue-green hornblende crystals as much as $5 \mathrm{~mm}$ long form much of the rock, and quartz, plagioclase $\left(A n_{65-70}\right)$, epidote, biotite, magnetite, sphene, sericite, chlorite, and clay comprise a small part of the rock. Estimates of the volume percent of the minerals in the hornblendite are listed in table 2.

The mineral assemblage that forms the biotite gneiss consists chiefly of quartz, calcic oligoclase, biotite, and muscovite and subordinate microcline and sillimanite. Other minerals that occur in trace amounts include apatite, magnetite, zircon, monazite(?), xenotime(?), and chlorite. The amounts of the chief minerals vary considerably from sample to sample, and the variations in composition of two samples are listed in table 2. Anhedral quartz and oligoclase compose most of the quartzo-feldspathic bands. Some quartz shows 


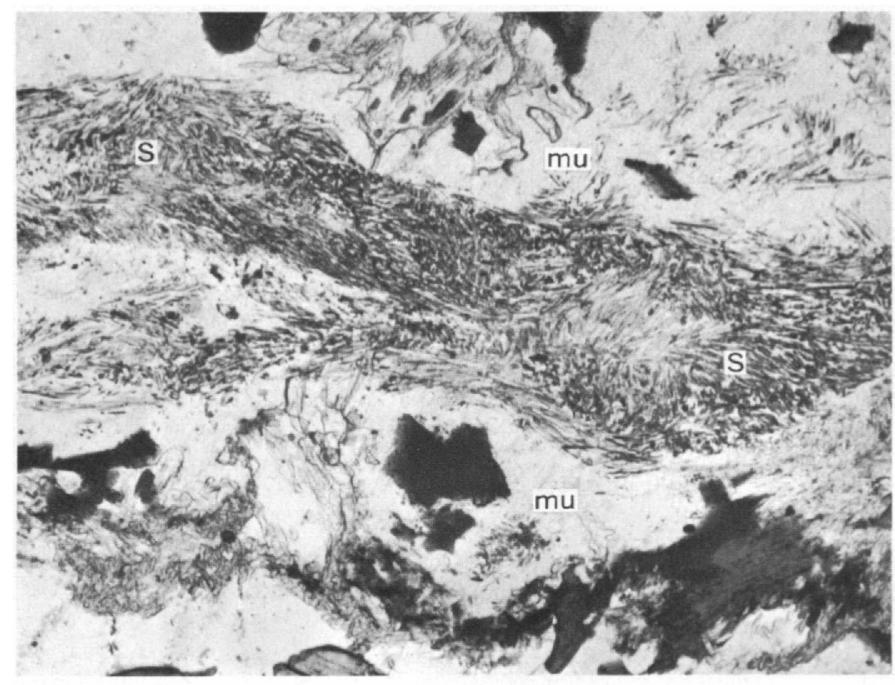

$\boldsymbol{A}$

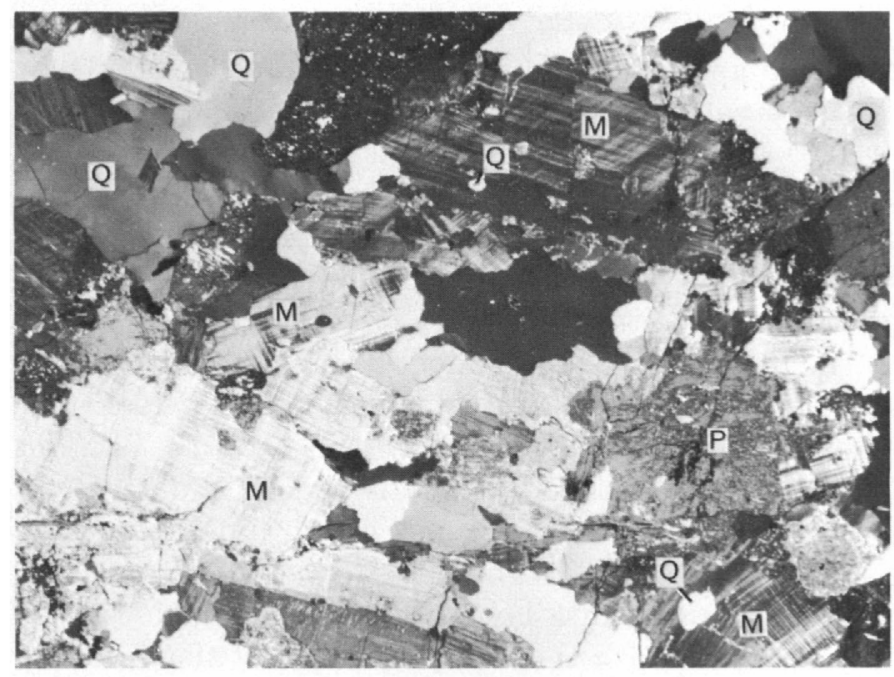

C

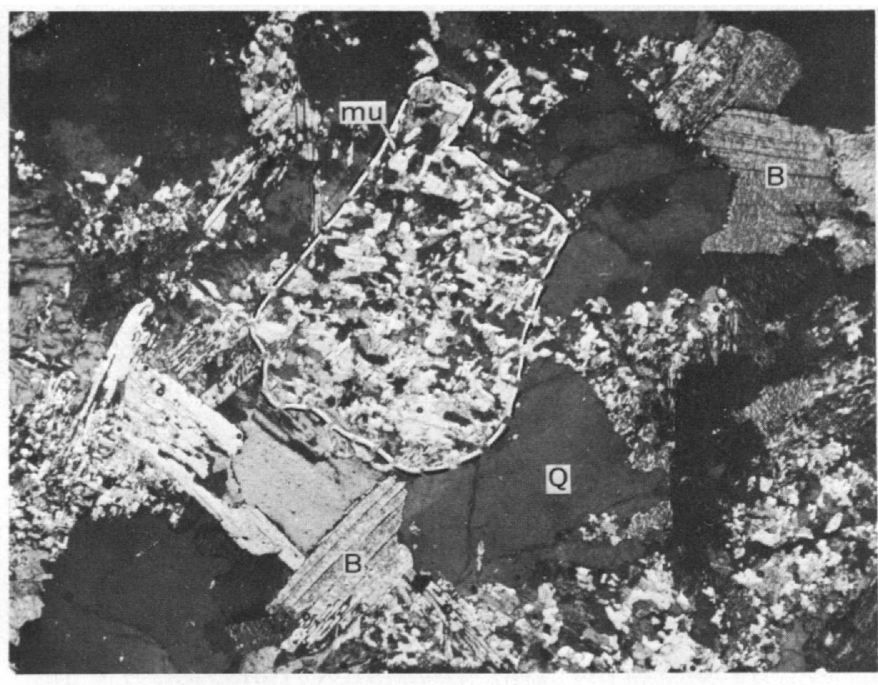

$B$

Figure 2.-Photomicrographs showing details of Precambrian rocks. $A$, Sillimanite needles in micaceous layer in biotite gneiss; $X 50$, plain light. $B$, Flakes and shreds of muscovite mixed with quartz that probably replaced a rectangular microcline grain; $\times 26$, crossed polars. $C$, Quartz blebs in microcline grain in quartz monzonite; $\times 50$, crossed polars. $B$, biotite; $M$, microcline; mu, muscovite; $P$, plagioclase; $\mathrm{Q}$, quartz; and $\mathrm{S}$, sillimanite.

slight undulatory extinction and sutured grain boundaries; other quartz shows sharp extinction and fairly straight grain boundaries. Oligoclase $\left(A n_{15-20}\right)$ that shows mottled zoning is not generally twinned, but where it is twinned, simple albite twinning is the common type. Dimensionally oriented biotite flakes are scattered through the quartzo-feldspathic bands. Biotite, which is locally altered to chlorite, makes up much of the micaceous bands that give the rock its strongly foliated character. Traces of grid-twinned anhedral microcline are sparsely scattered through the quartzo-feldspathic layers or are concentrated in migmatite-rich zones in crests of folds. Small amounts of sillimanite occur as needles in the quartzo-feldspathic layers or in sheaflike aggregates in the micaceous bands. Figure $2 A$ shows sillimanite in a large muscovite flake along a micaceous layer. White mica occurs in many samples of the biotite gneiss but seems to characterize the gneiss along the northern part of Cedar Ridge in areas heavily migmatized. The white mica in the biotite gneiss apparently formed at several times and occurs as (1) dimensionally oriented flakes that probably were biotite, (2) nonoriented larger flakes in the cores of folds, (3) small flakes mixed with quartz that probably replaced large subrectangular microcline grains (fig. $2 B$ ). and (4) thin layers of sericitic mica that probably were mixed biotite and sillimanite before the gneiss was downgraded.

No large-scale folds in the biotite gneiss could be mapped in the area, but planar and linear elements were measured to gain some information about the structure of the rocks. Foliations measured in the gneiss are mainly steep and, as shown on plate 1, generally trend between north and west. The foliation in the metasedimentary gneisses, which consists of preferred planar mineral orientation and compositional banding, is assumed to be parallel to the original bedding. The steep foliations in the gneisses may reflect the presence of steeply plunging southeast- or northwest-trending closed folds, but owing to the lack of stratigraphic marker beds, 
small outcrop area, and poor exposure, details of the trends and configurations of such folds could not be established. Interpretation of linear elements suggests that the biotite gneisses were folded at least twice during the Precambrian. Evidence from the mapped area and the adjacent Bottle Pass quadrangle to the southeast indicates that the oldest linear elements plunge southeast or northwest. Superposed later folding plunges northeast or southwest.

Linear elements in the gneiss include fold axes, mineral streaks, and small crenulations. Trends of the linear elements were plotted on the lower hemisphere of a Schmidt equal-area net and contoured. The contour diagram (fig. 3) shows that most of the folds in the area trend southeast or northeast with maximums at $65^{\circ} \mathrm{S} .45^{\circ} \mathrm{E}$. and $55^{\circ} \mathrm{N} .45^{\circ} \mathrm{E}$. Amplitudes of the small folds range from a few millimeters to as much as 10 feet, and the folds are, as defined by Moench, Harrison, and Sims (1962, p. 40), both open and closed. Many of the folds are probably drag folds that formed during differential movement of adjacent rock layers. The best example of a large drag fold occurs in the $\mathrm{NE} / 4$ sec. 26 , T. 1 N., R. $79 \mathrm{~W}$., a few feet below the maximum altitude of water level in the Williams Fork Reservoir. The fold plunges about $20^{\circ} \mathrm{S} .75^{\circ} \mathrm{E}$., has an amplitude of about 8 feet, and is markedly disharmonic. Mineral lineations in the gneiss are rare owing to the lack of elongate minerals, but streaks of biotite or clots of sillimanite along foliation planes on flanks of small folds usually parallel the axes of folds.

At a few localities in the area biotite gneiss shows evidence of superposed folds whose axes are at acute angles to each other. A photograph of a hand sample with such folding is shown in figure 4 , and the plunges and paired measurements of the trends of the superposed folds are listed below:

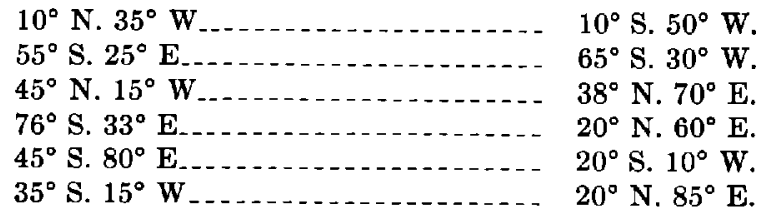

The fold directions seem to indicate northwest-southeast-plunging folds and northeast-southwest-plunging folds, but definitive proof of age relations between the two fold systems could not be found in the area. In the adjacent Bottle Pass quadrangle, however, R. B. Taylor (oral commun., 1963) found that the axes of the oldest fold system in the biotite gneiss plunge about $\mathrm{S} .35^{\circ} \mathrm{E}$. and that the axes of the youngest fold system plunge about N. $65^{\circ} \mathrm{E}$. The south-southeast fold system forms the predominant structural framework determining the outcrop pattern of the gneisses. The east-northeast system modifies the pattern and

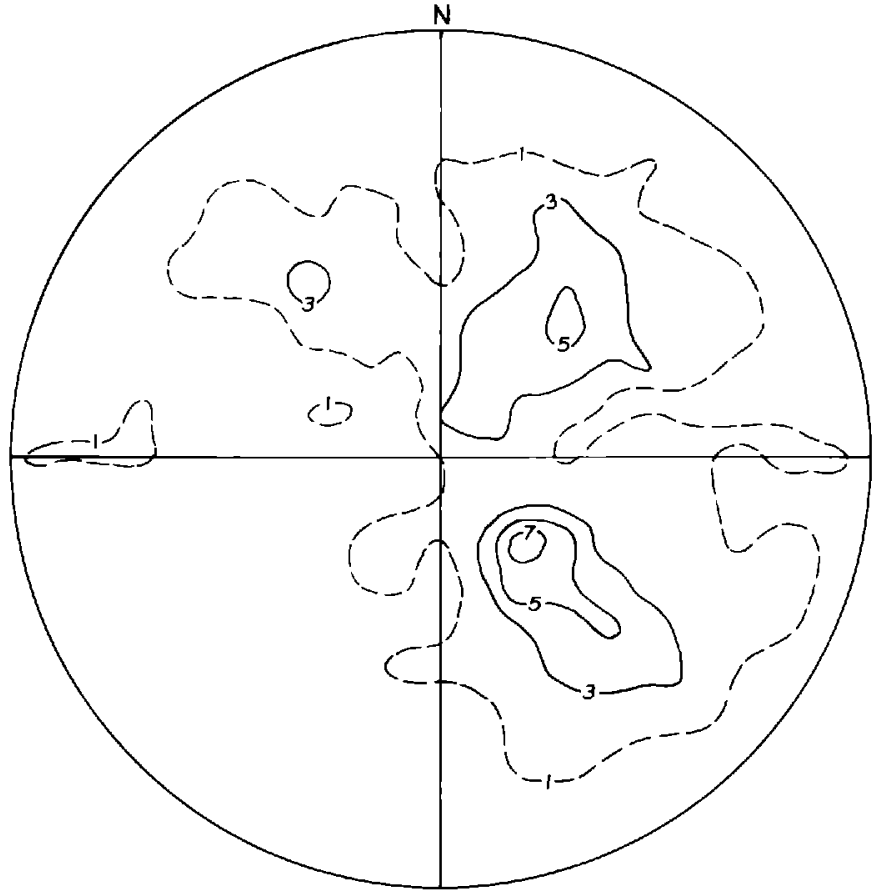

Figure 3.-Contour diagram of 300 lineations in biotite gneiss of Precambrian age plotted on the lower hemisphere of the Schmidt net. Contoured on percent poles.

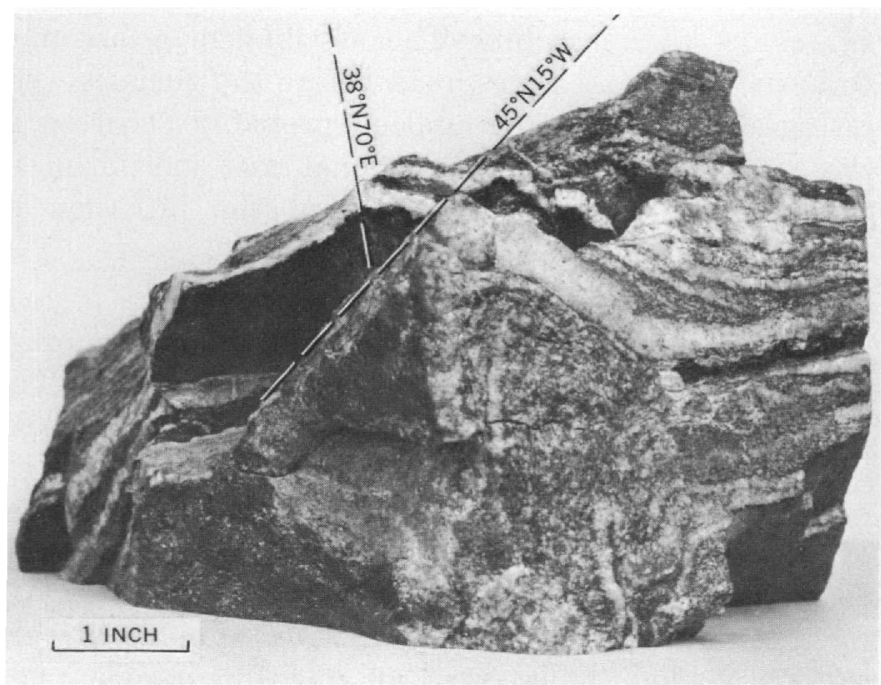

Figure 4.-Superposed folding in hand sample of biotite gneiss. Older fold(?) plunges $45^{\circ} \mathrm{N}$. $15^{\circ} \mathrm{W}$, and younger fold(?) plunges $38^{\circ} \mathrm{N}$. $70^{\circ} \mathrm{E}$.

locally dominates in belts of cataclasis. If the same tectonic pattern holds in the Hot Sulphur Springs quadrangle, the northwest-southeast-plunging fold system is the oldest.

Origin.-Compositional layering, small-scale banding, and lithic characteristics have led many geologists (including Ball, 1906, p. 375-376; Harrison and Wells, 1956, p. 38; Sims and others, 1958, p. 176-177; and Moench and others, 1962, p. 38) to conclude that the 
biotite gneisses in the Front Range are of metasedimentary origin. The biotite gneiss in the quadrangle and similar biotite gneiss in the Front Range are probably linked by a common origin and, in general, by a similar later history. Some of the details of the origin and history of the metasedimentary biotite gneisses in the Front Range are known from the work of many geologists, and some of this knowledge seems applicable to the metasedimentary gneisses in this quadrangle. The following generalizations seem justified. During the Precambrian, slightly pelitic quartzofeldspathic sedimentary rocks were regionally metamorphosed and transformed to sillimanite-bearing biotite gneiss. During regional metamorphism the rocks were migmatized, folded, and invaded by a few thin layers of Boulder Creek Granodiorite. At the peak of the regional metamorphism the rocks probably reached the sillimanite-almandine subfacies of the almandine amphibolite facies as defined by Fyfe, Turner, and Verhoogen (1958, p. 230-231). Later, the gneisses were retrograded so that sillimanite-microcline-muscovite is the prevailing assemblage. Thus, the characteristic mineral assemblage of the peak of the metamorphism (sillimanite-microcline) is rare in the biotite gneiss in the quadrangle and is indicated only by needles of sillimanite in microcline. The assemblage is assumed to have been more widespread before the gneisses were retrograded. The retrogradation probably occurred in the waning stages of the regional metamorphism in Precambrian time or accompanied the intrusion of quartz monzonite plutons.

\section{BOULDER CREEK GRANODIORITE}

A few small outcrops of granodiorite of Precambrian age were mapped near Williams Fork Reservoir. The name Boulder Creek Granodiorite is used for the rocks because of their similarity to the Boulder Creek Granodiorite of the Front Range, Colo., and to the bodies of Boulder Creek Granodiorite a few miles southeast in the Bottle Pass quadrangle mapped by R. B. Taylor (oral commun., 1964). Large areas of granodiorite are exposed a few miles west of the quadrangle. The granodiorite is younger than the biotite gneiss because the granodiorite clearly cuts the biotite gneiss in the NW $1 / 4$ sec. 35, T. 1 N., R. $79 \mathrm{~W}$. The contact is sharp, and foliations in the gneiss and the granodiorite parallel the contact. The Boulder Creek Granodiorite is older than the quartz monzonite because inclusions of granodiorite are found in the quartz monzonite in Byers Canyon. A whole-rock rubidium-strontium isotope age determination was made by C. E. Hedge of the U.S. Geological Survey on a sample of Boulder Creek Granodiorite collected by the writer from Byers Canyon. The sample was collected after blasting operations along U.S. Highway 40 in 1967. Hedge reports (written commun., 1967) that the age is $1.70 \pm .05$ billion years old and that the age clearly indicates that the rock is correlative with the Boulder Creek of the Front Range.

The granodiorite generally contains more biotite and is coarser grained than the quartz monzonite, and for these reasons the contrast between the rocks is generally sharp. The granodiorite typically weathers to crumbly rounded surfaces and contains mafic spindles and lenses as much as 4 feet long. Small concordant lenses of fine-grained equigranular granodiorite, too small to show on the map, occur in the biotite gneiss in sec. 22 , T. $1 \mathrm{~N}$., R. $79 \mathrm{~W}$. These lenses of granodiorite probably are satellite to a granodiorite body southwest of Williams Fork Reservoir in the Kremmling quadrangle.

The Boulder Creek Granodiorite is a medium-grained moderately well foliated mottled rock that locally contains a few scattered feldspar phenocrysts. Preferred orientation of biotite flakes and streaks is parallel to the slight elongation of quartz and feldspar, giving the rock a well-defined planar structure that could be either primary or metamorphic foliation because both types of foliation have been reported in granitic rocks in the region. To the west in the Kremmling quadrangle, foliation in small bodies of granodiorite parallels foliation in biotite gneiss. Most of the foliation in the granodiorite is probably metamorphic and formed during late stages of the regional metamorphism.

Study of the rock under the microscope shows it to be composed chiefly of plagioclase (33-57 percent) and quartz (24-45 percent) and of subordinate biotite, microcline, and white mica. Estimates of the volume percent of the minerals made by the point-count method are listed in table 3 . Although most of the rock is granodioritic in composition, locally the rock is classifiable as quartz diorite since it contains only small amounts of microcline. Many features of the granodiorite seen under the microscope are similar to those of the younger quartz monzonite, but the plagioclase $\left(\mathrm{An}_{36}\right)$ of the granodiorite is slightly more calcic than the plagioclase (An ${ }_{25-30}$ ) of the quartz monzonite.

\section{GRANITE}

The northernmost of the three ridges of Precambrian rock that occur in the quadrangle is chiefly a granite (greater than two-thirds of the total feldspar is microcline) in composition, but locally it ranges to quartz monzonite in composition. The granite is generally massive and weathers to rounded ridges and knobs. No linear or planar features were seen in hand samples of the rock although a few thin sections of the rock show elongation of quartz and feldspars.

The age of the granite is uncertain, but it is certainly pre-Laramide because the granite is cut by Laramide 
TABLE 3.- Representative modes (volume percent) of granite, quartz monzonite, and Boulder Creek Granodiorite

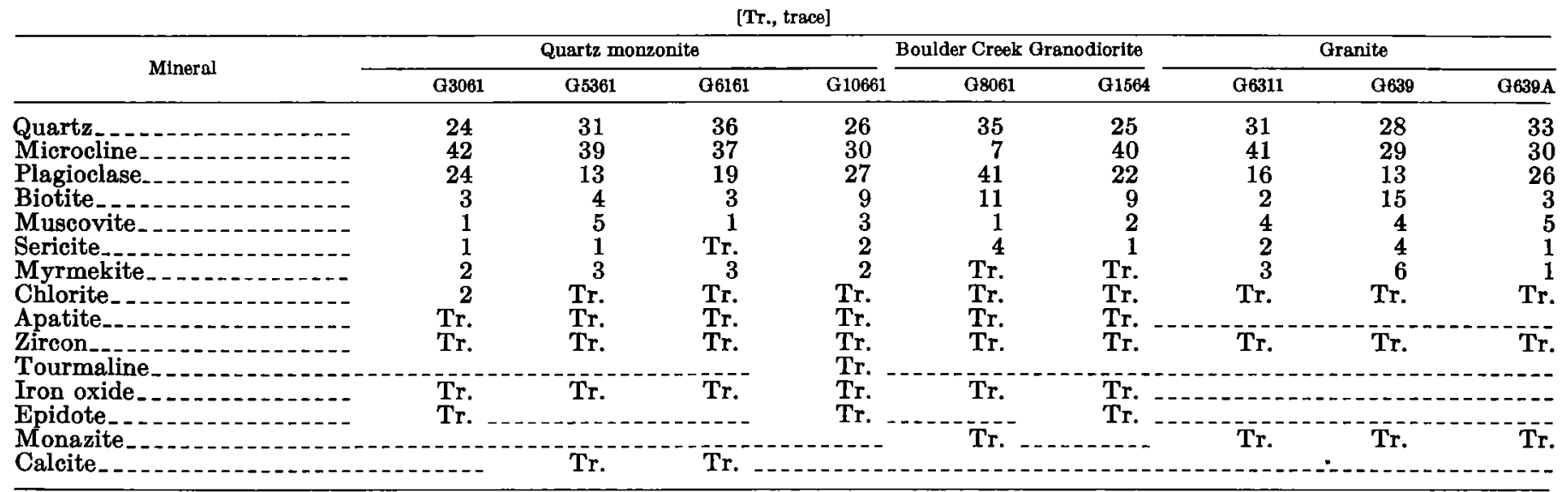

G3061. East end Byers Canyon along railroad.

G5361. West end Byers Canyon along U.S. Highway 40.

G6161. West end Byers Canyon along U.S. Highway 40.

G10661. NE1/4 sec. 17, T. 1 N., R. $78 \mathrm{~W}$.

G8061. Quartz diorite inclusion in quartz monzonite from Byers Canyon.

faults in and along Corral Creek. The granite is assumed to be of Precambrian age because of its lithic similarity to other granitic rocks of Precambrian age in the region. The granite occurs only in the upthrown block of the Corral Creek thrust fault, and field relations that would establish its age relative to other rocks of Precambrian age are lacking. The granite resembles silicic parts of the Boulder Creek Granodiorite of the Front Range in Colorado, and it may be about the same age.

The granite is a mottled medium-grained seriate porphyritic rock containing a few conspicuous feldspar grains as much as $2 \mathrm{~cm}$ long. The rock is the coarsest plutonic rock in the area. Because of the coarse grains the rock weathers rapidly, and many samples from the outcrop crumble easily in the hand. Study of the rock under the microscope shows that it is composed of quartz, microcline, and plagioclase and small amounts of biotite and muscovite. Estimates of the volume percent of the minerals are listed in table 3 . The quartz is anhedral and shows slightly sutured boundaries and undulatory extinction. The microcline is grid twinned and perthitic and contains rounded blebs of quartz, shreds of mica, and inclusions of plagioclase. The microcline is slightly altered to clay and commonly twinned on the carlsbed law. The plagioclase $\left(\mathbf{A n}_{26-30}\right)$ is subhedral and shows albite and albite-pericline twinning and mottled zoning. The plagioclase is markedly altered and is partly replaced by sericite. Other minerals in the rock are subhedral biotite and muscovite flakes and minor accessory minerals. Myrmekite occurs along some plagioclase and microcline contacts.

\section{BIOTITE-QUARTZ DIORITE}

Small plutons of biotite-quartz diorite of Precambrian age crop out in Byers Canyon and on south-facing

\section{G1564. NW1/4 sec. $35, T .1 N_{.,}$R. 79 W. G639. NE1/4 sec. 2, T. 1 N., R. 79 W.
G639A. NE1/4 sec. 2, T. 1 N., R. 79 W. G6311. NE3/4 sec. 1, T. 1 N., R. 79 W.}

slopes in secs. 15 and 16 , T. 1 N., R. 78 W., in the southern part of the quadrangle. The largest of the plutons is a northeast-trending elongate mass that is exposed in roadcuts along U.S. Highway 40 and along walls in Byers Canyon. Next to contacts with other Precambrian rock units the biotite-quartz diorite is well foliated, but the interior parts of the plutons appear massive. Foliations are generally steep and parallel the contacts.

The biotite-quartz diorite is a medium- to dark-gray equigranular mottled rock whose dark color contrasts sharply with the lighter color of adjacent rocks of Precambrian age in Byers Canyon. It is fine to medium grained and contains conspicuous books of biotite. Quartz (35-47 percent), plagioclase (18-24 percent), biotite (16-31 percent), and hornblende (0-9 percent) are the main constituents; allanite, apatite, chlorite, epidote, sericite, sphene, and iron oxides occur in trace amounts in the rock. Percentages of these minerals from several samples of the rock are listed in table 4 .

Under the microscope the rock appears holocrystalline and has a granitic texture. The quartz is anhedral,

$\mathrm{T}_{\mathrm{ABLE}}$ 4.-Representative modes (volume percent) of biotite-quartz diorite

[All samples from Byers Canyon. Tr., trace]

\begin{tabular}{|c|c|c|c|c|c|}
\hline \multirow{2}{*}{ Mineral } & \multicolumn{5}{|c|}{ Sample } \\
\hline & G75-61 & G55-61 & $G 27-61$ & G28-61 & G74-61. \\
\hline Quartz_. & 35 & 42 & $\overline{44}$ & 37 & 47 \\
\hline Plagioclase_- & 21 & 24 & 18 & 19 & 21 \\
\hline Biotite._. & 31 & 22 & 23 & 25 & 16 \\
\hline Hornblende. & 7 & & 9 & & 9 \\
\hline Sericite & 3 & 7 & 2 & 15 & 5 \\
\hline Epidote & 2 & $\dot{2}$ & 1 & Tr. & $\mathrm{Tr}_{\mathbf{r}}$ \\
\hline Allanite & & & Tr. & Tr. & Tr. \\
\hline Apatite.-. & Tr. & Tr. & Tr. & Tr. & Tr. \\
\hline Sphene_- & Tr. & Tr. & Tr. & Tr. & Tr. \\
\hline Chlorite & Tr. & Tr. & 2 & Tr. & Tr. \\
\hline Pyrite and magnetite & Tr. & Tr. & Tr. & 3 & Tr. \\
\hline Prehnite... & Tr. & Tr. & Tr. & Tr. & Tr. \\
\hline
\end{tabular}


shows wavy extinction, and has sutured grain boundaries. The plagioclase shows mottled zoning and albite, pericline, and carlsbad twinning. Extinction angles $(X \wedge(010)$ max.) measured with the universal stage indicate that the composition of the plagioclase ranges from $A n_{45}$ to $A n_{65}$ and averages about $A n_{50}$. Subhedral biotite flakes as much as $3 \mathrm{~mm}$ long contain thin lenses of prehnite(?) interlaminated along the (001) cleavage. Prehnite occurs in biotite in some Precambrian rocks in the Boulder quadrangle, where it was identified by Wrucke (1965). The hornblende $\left(2 \mathrm{~V}_{\mathrm{x}}=71 ; \mathrm{n}_{\mathrm{y}}=1.666\right)$ is subhedral, fresh, and rarely twinned. Diagnostic features of the rock are its lack of alkali feldspar and the presence of prehnite along the biotite cleavages.

The age of the biotite-quartz diorite relative to adjacent rocks of Precambrian age was determined from contact relations in Byers Canyon. At many places the biotite-quartz diorite is cut by, or occurs as inclusions in, the quartz monzonite and is, therefore, older than the quartz monzonite. Where U.S. Highway 40 crosses the line between secs. 9 and $10, T$. 1 N., R. $78 \mathrm{~W}$., biotite-quartz diorite seemingly cuts Boulder Creek Granodiorite inclusions in quartz monzonite, and foliation in the biotite-quartz diorite at this locality is parallel to the contact between the rocks and is normal to the foliation in the granodiorite. Although not definitive, these relations suggest that the biotitequartz diorite is younger than the Bouler Creek Granodiorite. The biotite-quartz diorite is assumed to be younger than the biotite gneiss because in the adjacent Bottle Pass quadrangle rocks similar to the biotite-quartz diorite cut biotite gneiss (R. B. Taylor, oral commun., 1963).

\section{QUARTZ MONZONITE}

Plutonic rocks of Precambrian age that consist chiefly of quartz monzonite and associated aplite, alaskite, and pegmatite form much of the middle ridge of Precambrian rock in the southern part of the quadrangle. Good exposures of the quartz monzonite occur in the steep walls of Byers Canyon and along the lower reaches of Corral Creek. On the north side of Byers Canyon the quartz monzonite is sliced by many closely spaced nearly vertical joint sets, and it weathers to characteristic castellated cliffs. The quartz monzonite is contaminated along the eastern part of its outcrop belt mainly by inclusions and irregular masses of granodiorite and along the western part of its outcrop belt mainly by lenses and layers of contorted migmatitic biotite gneiss and schist. All these rocks are readily separable in hand sample or in isolated outcrops, but owing to complex intermixing of the rocks and poor exposure, the details of their spatial relations are not precisely known. However, the areas underlain by quartz monzonite that are mainly contaminated by gneiss and schist are roughly differentiated on the map (pl. 1).

The quartz monzonite is younger than the Boulder Creek Granodiorite as determined from contact relations in Byers Canyon. A whole-rock rubidium-strontium isotope age of a sample of the quartz monzonite was determined by C. E. Hedge of the U.S. Geological Survey. The sample was collected in 1967 from freshly blasted outcrops along U.S. Highway 40 in Byers Canyon. Hedge reported (written commun., 1967) that the quartz monzonite is $1.65 \pm .04$ billion years old. Although the quartz monzonite somewhat resembles the Silver Plume Granite of the Front Range, the rock is significantly older than the Silver Plume.

The quartz monzonite was seemingly intruded after the regional metamorphism because it lacks the foliation that characterizes the syntectonic Boulder Creek Granodiorite.

The quartz monzonite is a pink or grayish-pink fineto medium-grained rock that locally has a weak trachytoid texture. In some areas the quartz monzonite grades into coarse-grained granite, alaskite, or aplite and is cut by east-trending quartz-feldspar-mica pegmatite. The rock locally shows platy flow structure or foliation that is formed by preferred orientation of micaceous minerals, platy inclusions, and wispy biotite schlieren. At the south end of Byers Canyon, platy inclusions of metasedimentary rocks and altered biotite-quartz diorite parallel preferred orientation of micaceous minerals and give the rock a well-foliated appearance. Quartz (24-36 percent), plagioclase (13-27 percent), and microcline (30-42 percent) compose most of the rock; small amounts of biotite and muscovite are also present. Representative modes of a few samples of the quartz monzonite are listed in table 3 . Under the microscope quartz is seen to be fresh and to have slightly sutured boundaries. Some quartz occurs as rounded inclusions in microcline. These inclusions are typical of the rock and are shown in figure 2. Subhedral plagioclase $\left(A n_{25-30}\right)$ that shows albite twins and mottled zoning is invariably turbid, whereas anhedral microcline that shows grid twinning is generally clear. Subhedral biotite and muscovite occur as randomly oriented flakes or as streaks that parallel the crude elongation of quartz and feldspar. Some of the biotite is altered to muscovite that contains iron-oxide concentrations along cleavage directions. Minor accessory minerals that form a small part of the rock are listed in table 3.

In Byers Canyon, well-exposed outcrops of the quartz monzonite show large inclusions and irregular masses of Boulder Creek Granodiorite. Figure 5 shows granodiorite inclusions in quartz monzonite. Some of the inclusions of granodioritic rock have been rotated, as shown by various attitudes of foliation in adjacent 


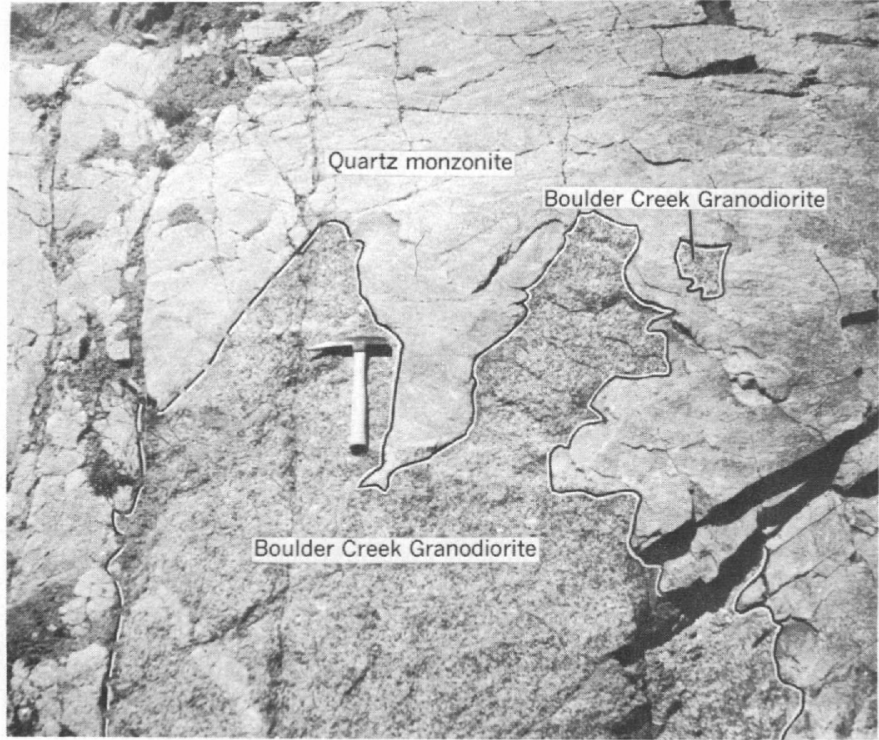

Figure 5.- Inclusions of Boulder Creek Granodiorite in quartz monzonite in Byers Canyon.

inclusions. After rain squalls, when outcrops are wet, the granodiorite inclusions contrast sharply with the quartz monzonite country rock. Field relations seem to indicate that the area of granodiorite-contaminated quartz monzonite represents an intrusion breccia along a contact zone between the quartz monzonite and the granodiorite. Owing to poor exposure away from Byers Canyon, the trace of the contact zone is uncertain.

In the western part of the ridge of quartz monzonite, biotite gneiss layers that are locally sillimanitic form discontinuous lenses several tens of feet thick in a dominantly granitic terrane. The foliation in the biotite gneiss is variable but generally trends northwest. Samples of the biotite gneiss are generally similar in composition to parts of the biotite gneiss along Cedar Ridge. Small-scale folds in the biotite gneiss layers are rare, and not enough measurements could be made to establish tectonic relations between the gneiss and the quartz monzonite.

\section{MESOZOIC ROCKS} MORRISON FORMATION

Varicolored mudstone, sandstone, siltstone, and thin limestone beds above Precambrian crystalline rocks and below chert-pebble conglomerates of the Dakota Sandstone are assigned to the Morrison Formation of Late Jurassic age in the mapped area. These beds are similar to, and correlate with, the Morrison Formation at its type locality about 60 miles to the southeast. The Morrison forms poorly exposed grass- and rubblecovered slopes below sandstone ridges of the Dakota in the southern part of the quadrangle, but moderately well exposed sections were measured at Byers Canyon and near Williams Fork Reservoir. The lower part of the section at Byers Canyon is faulted, but a section (p. 16) was measured to show the general character of the formation.

The Morrison is the oldest sedimentary rock unit in the quadrangle, but elsewhere in Middle Park older sedimentary rocks are found. Several miles east of the quadrangle, at Tabernash Campground, a thin sequence of beds equivalent to part of the Sundance Formation (Late Jurassic) and the Chugwater(?) Formation (Triassic and Permian) lies between the Morrison and the Precambrian crystalline rocks. West of the quadrangle, a few miles north of Kremmling, Colo., rocks that are equivalent to the Sundance, the Chinle, and the Chugwater locally occur below the Morrison.

The thickness of the Morrison Formation in the quadrangle is not precisely known owing to faults, poor exposures, and the poorly defined nature of the Morrison-Dakota contact. The contact between the Morrison and the Dakota was chosen arbitrarily at the base of the lowest lenticular conglomeratic sandstone or, where conglomerates are absent, at the base of the lowest massive lenticular sandstone. These lenticular sandstones are not laterally persistent, and, accordingly, thicknesses of the Morrison and the Dakota show marked variations. The Morrison is about 300 feet thick half a mile downstream from Williams Fork Reservoir; at the east end of Byers Canyon, where the lower part of the formation is faulted, the Morrison is probably about 200 feet thick. Elsewhere in southern Middle Park, the Morrison seems to range in thickness between 100 and 300 feet. In the Fraser area, R. B. Taylor (oral commun., 1962) reported that the Morrison is $150-250$ feet thick where it has not been squeezed by folding. At Green Mountain along the Blue River valley, Tweto (1957) stated that the Morrison is about 200 feet thick. In northwestern North Park, Colo., Hail (1965, p. 25) reported that the Morrison ranges in thickness from about 310 to 431 feet.

The Morrison in the quadrangle consists of complexly interbedded siltstone, montmorillonitic mudstone, sandstone, and limestone. The sandstone beds are light gray, thin to very thick bedded, and moderately well sorted. The lowest sandstone bed in the Morrison is poorly sorted, conglomeratic, and arkosic in the lower 2-3 feet. The siltstones and sandstones are locally limy in the lower part of the Morrison, where they are interbedded with thin beds of light-gray dense fresh-water limestones. The mudstones are varicolored, mostly in shades of light green, pale red, and dusky yellow. Some mudstones are limy and contain flecks of pyrite and marcasite. Heavy minerals from the Morrison are listed in table 10.

A thick sandstone (unit 3, p. 17) near the base of the Morrison exposed at Bvers Canyon has a somewhat 
similar appearance to marine sandstone beds of Late Jurassic age exposed 15 miles to the north and west (Sundance and Entrada equivalents). The presence of a similar sandstone above marine Upper Jurassic beds measured by G. N. Pipiringos (oral commun., 1963) 15 miles west in the Kremmling area, however, suggests that unit 3 of the Byers Canyon section belongs in the Morrison Formation.

The Jurassic age of the Morrison Formation in the mapped area is established by its stratigraphic position and by a few fossils. Ostracodes collected by the writer from about 100 feet above the base of the Morrison along U.S. Highway 40 in Byers Canyon were identified by I. G. Sohn (written commun., 1964) as "Metacypris", Darwinula spp., Camplocythere? sp., and an indeterminate genus with a smooth carapace. Sohn stated: "The faunal make-up does not contradict a Morrison age; in fact, I recognize elements *** from the Morrison Formation in the Black Hills." During the Hayden survey, a partial vertebra of Antrodemus was found in beds of possible Morrison age somewhere in Middle Park and "was probably derived from a formation of Cretaceous age" (Leidy, 1873, p. 267-268). In 1873 the Morrison was considered to be of Cretaceous age. G. N. Pipiringos found an imprint of a coniferous cone, identified as Araucarites by R. A. Scott (written commun., 1963) of the U.S. Geological Survey, preserved on a piece of sandstone float at the foot of a slope on the Morrison Formation in the SE1/4 NW $1 / 4$ sec. 10 , T. 1 N., R. $76 \mathrm{~W}$., in the Granby quadrangle. According to Scott, Araucarian conifers were a significant component of the Morrison flora, although they are not diagnostic of Morrison age.

Measured sections that give details of the lithic character of the Morrison follow the discussion of the Dakota Sandstone.

\section{DAKOTA SANDSTONE}

The Dakota Sandstone is the lowest formation of the Lower Cretaceous Series in the mapped area and consists of interbedded conglomeratic sandstone, sandstone, and clayey siltstone. It crops out in three subparallel northwest-trending belts in the southern part of the area. Generally, it is poorly exposed and forms sage- and tree-covered slopes. The only complete exposures of the Dakota are along the Colorado River at the east end of Byers Canyon and along the Williams Fork about half a mile north-northeast of Williams Fork Reservoir. Figure 6 shows the Dakota and the Morrison at the east end of Byers Canyon.

Although the Dakota is poorly exposed, in some places it can be divided roughly into a lower, conglomeratic sandstone part and an upper, even-bedded sandstone and siltstone part. The lower part is similar to the Lytle Formation, and the upper part resembles the South Platte Formation of the Dakota Group

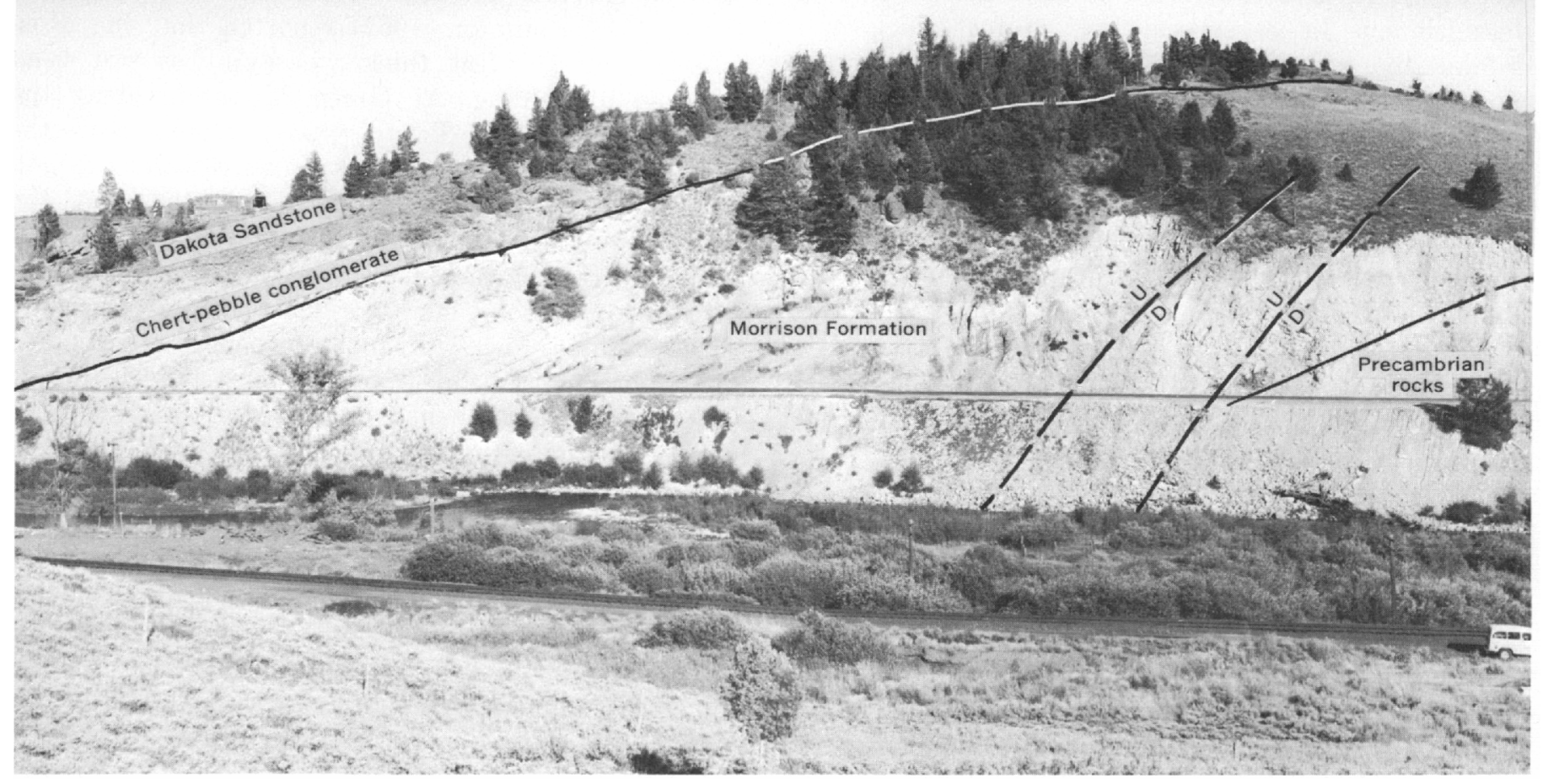

Figure 6.-Dakota Sandstone and Morrison Formation at the east end of Byers Canyon, along U.S. Highway 40. Two small faults cut the lower part of the Morrison Formation. 
along the northern Front Range foothills as described by Waagé (1955). The lower and upper parts were not mapped separately in the area because of the poor exposures and the lack of a persistent mappable lithic break between the parts.

The Dakota Sandstone is about 185 feet thick at the east end of Byers Canyon and about 230 feet thick near Williams Fork Reservoir. Thicknesses of Dakota elsewhere in Middle Park reported by others (Lovering and Goddard, 1950; Tweto, 1957; Jenkens, 1957) are fairly similar to those in Hot Sulphur Springs quadrangle. In northwestern North Park, Hail (1965, p. 30) stated that the Dakota ranges in thickness from about 170 to 235 feet.

The lower part of the Dakota generally consists of light-gray to brown lenticular conglomeratic fine- to medium-grained poorly sorted sandstone beds as much as 25 feet thick. White, gray, and black well-rounded smooth chert pebbles as much as 2 inches in diameter form at least 95 percent of the pebbles. Some of the chert pebbles contain crinoid stems and unidentifiable fossil debris. Other pebbles are white quartz or red quartzite. The sand-sized fraction of the Dakota is mainly quartz and contains moderate amounts of chert grains and a few percent feldspar grains. Results of heavy-mineral separations are shown in table 10 and are discussed in another section. The lower part is chiefly thick bedded and massive and shows high-angle medium-scale planar cross-stratification.

The upper part of the Dakota locally seems to grade into the lower part in some areas, but in the $\mathrm{SE}_{74}^{1 /}$ sec. 3, T. 1 N., R. 79 W., conglomeratic sandstone of the upper part fills a scoured surface cut in the lower part. The upper part consists mainly of well-sorted finegrained light-gray sandstone that weathers light brown. The lower and upper parts mostly form slopes and ledges and consist of light- to dark-gray carbonaceous clayey subfissile siltstones intercalated with thinbedded very fine grained sandstone beds. Locally, the upper part is quartzitic and forms a prominent sandstone ridge. The sandstones and siltstones consist chiefly of quartz, some chert, and a few percent feldspar. The sandstone beds are locally conglomeratic, and the pebbles consist of chert, quartz, quartzite, and clay galls.

The sandstone beds are generally thick to thin bedded; the siltstones are thin bedded to laminated. Cross-stratification is mainly low angle, simple, and lenticular and includes some high-angle, planar, and tabular crossbeds (McKee and Weir, 1953). Surfaces of sandstone and siltstone beds in the upper part show 3- to 4-inch oscillation and current ripple marks and trails and borings of soft-bodied organisms. The upper part overlies the continental sediments of the lower part and underlies and grades into the marine Benton
Shale; the upper part undoubtedly represents the transition from a continental to a marine environment.

The contact between the Dakota and the Morrison was picked arbitrarily at the base of the lowest chertpebble conglomerate or massive sandstone bed that rests on a scoured surface of the Morrison Formation. The conglomeratic beds are lenticular channel-fill deposits, and the scoured surfaces at their base that are used to separate the Morrison and the Dakota may have only local significance.

The Dakota Sandstone probably was deposited over flood plains, on tidal flats and marshes, in estuaries, or in swamps. The lower part of the Dakota seems to have been deposited in a continental environment mainly on flood plains. Conglomeratic channel-fill deposits that have high-angle tabular cross-stratification characterize the lower part, which seems allied lithogenetically to the underlying Morrison Formation The upper part of the Dakota grades upward into the marine Benton Shale and is characterized by lowangle simple lenticular cross-stratification. Ripple marks, trails, and borings of soft-bodied organisms, large amounts of carbonaceous debris, and even-bedded sandstones and siltstones in the upper part suggest that'it was deposited in a marginal marine environment.

No fossils other than poorly preserved plant debris and trails and borings of soft-bodied organisms were seen in the Dakota. The Early Cretaceous age of the Dakota Group along the Front Range is well established by marine fossils (Waagé, 1955). The Dakota Sandstone in the mapped area overlies the Morrison Formation and underlies beds in the lower part of the Benton Shale dated as Early Cretaceous.

The following measured sections give details of the lithic character of the Dakota.

Section of the Dakota Sandstone and Morrison Formation below Williams Fork Dam in the SW1/4 sec. 13, T. 1 N., R. $79 W$.

[Measured by G. A. Izett, A. L. Wanek, and C. S. V. Barclay] Benton Shale (part):

Thickness

11. Siltstone, medium-gray, slightly carbonaceous, clayey; intercalated with light-gray very fine grained thin-bedded to laminated sandstone; forms slope....... Partial thickness of Benton Shale...... 10

Dakota Sandstone:

10. Sandstone, light-gray, very fine-grained, thinbedded, well-bedded; has low-angle small- to medium-scale cross-stratification; contains carbonaceous debris; intercalated with lightgray siltstone that forms most of upper part of unit; shows trails and tubes of soft-bodied organisms; joint surfaces stained with iron oxide; forms ledges.......................

9. Siltstone, medium-gray, laminated; has lowangle cross-stratification; contains carbonaceous debris; shows ripple marks; forms slope 
Section of the Dakota Sandstone and Morrison Formation below Williams Fork Dam in the SW1/4 sec. 19, T. 1 N., R. 79 W.-Con.

Dakota Sandstone-Continued

8. Sandstone, light-gray, fine-grained; thin bedded in lower and upper parts, thick bedded in middle of unit; has low-angle medium-scale sweeping cross-stratification; locally quartzitic, massive; shows ripple marks and trails of soft-bodied organisms; contains a few 1-in.thick light-gray siltstone interbeds; forms massive cliff - . - . - .

7. Mostly covered; probably consists of light-gray siltstone and very fine grained sandstone; forms slope.

6. Sandstone, light-gray, fine- to medium-grained, well-sorted, thin- to thick-bedded, massive; lower surface is local scour surface; contains white chert specks; has medium-scale low-angle cross-stratification; forms prominent ledge...-

Thickness of Dakota Sandstone (rounded) -Thickness
$(f t)$

\section{Morrison Formation:}

5. Claystone, light-greenish-gray, silty, locally limy, structureless; interbedded with light-gray poorly bedded siltstone; contains a few thin discontinuous dense limestone beds; forms slope

4. Sandstone, light-gray, fine-grained, thin-bedded. contains limy quartz and chert granules; forms ledges

3. Claystone, light-greenish-gray, silty, locally limy, structureless; interealated with thin dense limestone beds and a few thin limy sandstone beds; forms slope

2. Mostly covered; some variegated reddish-brown and greenish-gray silty and sandy claystone intercalated with thin limestone and limy sandstone beds; base of unit not exposed.....

Thickness of Morrison Formation

Precambrian:

1. Biotite gneiss.

Section of the Benton Shale, Dakota Sandstone, and Morrison Formation at Byers Canyon in the SE1/4 sec. S, T. 1 N., R. $78 \mathrm{~W}$. [Measured by G. A. Izett and D. L. Hoover]

Benton Shale (part):

20. Siltstone, medium-gray, laminated, partly covered; contains flecks of carbonaceous debris and a few thin bentonite beds; exposed along south bank of Colorado River

19. Siltstone, medium-light-gray, thinly laminated; contains flecks of carbonaceous debris; joint surfaces stained with iron oxide; contains a few thin 2-in.-thick bentonite beds.

18. Siltstone, light-gray, clayey, very thin bedded. contains 1-ft-thick bed of medium-gray siltstone in middle of unit; contains flecks of carbonaceous debris

17. Siltstone, medium-light-gray, slightly clayey, thinly laminated to thin-bedded; contains a few thin light-gray siltstone beds in lower part, flecks of carbonaceous debris, and a few thin bentonite beds

16. Siltstone, medium-gray, laminated to thinbedded; has trails of soft-bodied organisms
Section of the Benton Shale, Dakota Sandstone, and Morrison Formation at Byers Canyon in the SE1/4 sec. B, T. 1 N., R. $78 \mathrm{~W}$.-Continued

Benton Shale-Continued

16.-Continued

along bedding planes; contains flecks of carbonaceous debris; intercalated with some very fine grained sandstone; exposed in cut along Colorado River; has gradational contact with underlying Dakota Sandstone......

Partial thickness of Benton Shale (rounded).

Thickness

Dakota Sandstone:

15. Sandstone, light-gray, very fine grained, laminated to thin-bedded; intercalated with medium- to dark-gray carbonaceous siltstone; has markings of soft-bodied organisms; ex-

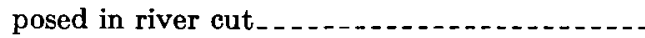

14. Covered.....

13. Sandstone, light-gray, very fine grained, quartzose, thin- to thick-bedded; shows asymmetric ripple marks with 3 -in. wavelength; has trails and markings of soft-bodied organisms; forms cliff along southeast side of Colorado River

12. Sandstone, light-gray (weathers light brown), fine-grained, quartzose, thin- to thick-bedded; shows symmetric and asymmetric ripple marks with 3-in. wavelength; contains a few thin light-gray siltstone splits less than 2 in. thick; forms ridge.

11. Sandstone, light-gray, very fine grained, thinbedded; contains siltstone partings; forms ridge

10. Sandstone, light-gray, very fine grained to fine-grained, very thick bedded, massive; has wedge-shaped medium-scale cross-stratification; contains rounded smooth chert pebbles 2 in. in diameter near base of unit; base of unit appears to rest on scoured surface; contains scattered chert and siltstone granules throughout, and siltstone split $6.5 \mathrm{ft}$ below top; forms ridge

9. Siltstone, very light gray, sandy, thinly laminated to thin-bedded; forms slope

8. Conglomerate, light-gray, fine-grained, very thick bedded, massive; sandstone matrix contains gray, black, and white round chert pebbles as much as 2 in. in diameter and a few percent quartz and quartzite pebbles; some chert pebbles contain crinoid stems and other fossil debris; base of unit rests on scoured surface; forms ridge...........

Thickness of Dakota Sandstone._._._.

Morrison Formation:

7. Sandstone, very light gray, very fine grained; intercalated with varicolored mudstone like that of underlying unit; locally limy; contains iron-oxide concretions near base; has complexly interbedded lenticular units, and has several thin discontinuous dense light-gray clayey limestone beds in lower part; exposed in roadcut

6. Mudstone, variegated pale-olive (10Y 6/2), palered (10R 6/2), and dark-gray $(N 3)$, structureless, sandy; contains a few thin discontinuous limy siltstone beds. 
Section of the Benton Shale, Dakota Sandstone, and Morrison Formation at Byers Canyon in the $S E V_{4} / \mathrm{sec} .9, T .1 \mathrm{~N} ., R 78 \mathrm{~W}$.Continued

Morrison Formation-Continued

5. Siltstone, grayish-orange $(10 Y R$ 6/2), limy, structureless, hard, lenticular; weathers to rounded forms . . . . . . .

4. Mudstone, variegated dusky-yellow-green ( $5 G Y$ $5 / 2$ ) and grayish-red (10R 4/2), limy; includes a few thin discontinuous limy siltstone beds containing some marcasite flecks; exposed in roadcut.......................................

Fault zone.

3. Sandstone, very light gray, very fine grained, thin- to thick-bedded, quartzose; contains a few white specks (chert?); contains a few small faults with a 4-ft displacement

2. Sandstone, very light gray, slightly micaceous, thin-bedded; has very fine grained matrix containing quartz and microcline pebbles as much as $8 \mathrm{~mm}$ in diameter. Thickness of Morrison Formation (rounded) .. Precambrian:

1. Crystalline rocks.

\section{BENTON GHALE}

The Benton Shale of Early and Late Cretaceous age, the oldest unit that is clearly part of the marine Cretaceous sequence, forms grass- and sage-covered gentle slopes above the hogback-forming Dakota Sandstone in the mapped area. The lower part of the Benton can be seen along the south bank of the Colorado River near the west edge of Hot Sulphur Springs, at the west end of the footbridge along the Colorado River on the Sunset Ranch in the SW $1 / 4 \mathrm{SW} 1 / 4$ sec. 11, T. 1 N., R. 79 W., and along the Williams Fork. The upper part of the Benton can be seen in sec. 11, T. 1 N., R. 78 W., but elsewhere in the quadrangle the Benton is covered by soil, grass, and sage. A partial measured section of the Benton is included in the description of the Morrison and the Dakota at Byers Canyon.

Although poor exposures preclude accurate measurement, the Benton is estimated to be about 450 feet thick in the mapped area. Bombolakis (1958) estimated the Benton to be 500 feet thick in the quadrangle. Elsewhere in Middle Park, Holt (1961) reported 340 feet of Benton near Dillon, Colo., and Jenkens (1957) measured 418 feet of Benton along Red Dirt Creek near Kremmling, Colo. Thicknesses of the Benton estimated from electric logs of wells drilled for oil and gas in the quadrangle in 1957-Murphy-Bill Hewit Corral Peak 1 and Lion Linke State 1-average about 450 feet.

The lower 20 feet of the Benton is mainly light- to dark-gray hard subfissile clayey siltstone that is very thin bedded to laminated and carbonaceous. Rocks in this interval resemble parts of the Mowry Shale of
Early Cretaceous age. Light-gray very fine grained sandstone and a few bentonite seams as much as 2 inches thick are interbedded with the siltstone. Worm trails and fossil fish scales occur on bedding surfaces of the siltstone and sandstone beds. The middle part of the Benton was nowhere seen in detail, but scraps of float suggest that it consists of dark-gray silty shale. The topmost ledge-forming beds of the Benton form good stratigraphic markers because they include a distinctive thin-bedded fine-grained sandstone about 5-10 feet thick overlain by a recrystallized fossiliferous brown-weathering limestone bed about 5 feet thick. In sec. 11, T. 1 N., R. $78 \mathrm{~W}$., the sandstone contains stringers of black and gray chert pebbles as much as 1 inch in diameter. The sand grains are mainly quartz (75 percent), chert (24 percent), and feldspar (1 percent). Some of the quartz grains show secondary overgrowth. Heavy minerals separated from samples of the sandstone are listed in table 10. The limestone is recrystallized and contains fossil debris consisting of calcite and some collophane.

The contact between the Benton and the Dakota is gradational through several tens of feet. The contact was chosen where medium- to dark-gray carbonaceous siltstone and shale (Benton) is more prevalent than light-gray very fine grained sandstone and mediumgray siltstone (Dakota). Waagé (1955) described the contact of the Dakota and the Benton as transitional through 20 feet in some places and as sharp in other places along the eastern Front Range, Colo. According to Lovering and Goddard (1950, p. 39), the contact is locally disconformable east of Dillon, Colo., where a thin conglomerate marks the base of the Benton. In the Kremmling area, C. S. V. Barclay (oral commun., 1965) reported a thin conglomerate at the base of the Benton.

Marine fossils, including Prionocyclus cf. $P$. wyomingensis, Inoceramus dimidius, Scaphites sp., Ostrea sp. (fossil localities 31 and 32 , pl. 1), and sharks' teeth, were found in the SW $1 / 4 \mathrm{NE} / 4$ sec. $11, \mathrm{~T} .1 \mathrm{~N} .$, R. 78 $W$., in a brown-weathering limestone near the top of the Benton. According to W. A. Cobban (written commun., 1961), who identified the fossils, their presence indicates a Late Cretaceous age and suggests that the sandstone and limestone beds at the top of the Benton correlate with the uppermost beds in the Carlile Shale of the Front Range, the Codell Sandstone Member of the Carlile of eastern Colorado and western Kansas, and the Juana Lopez Member of the Carlile of New Mexico. D. H. Dunkle (written commun., 1964) identified fossil scales of teleostean fishes that include Holcolepis, Leucichthyops, and Ichthyodectes collected from the lower 30 feet of the Benton along the Colorado River in the $\mathrm{SE}_{1}^{1} \mathrm{SEE} / 4 \mathrm{SE} / 4$ sec. $3, \mathrm{~T}$. 
$1 \mathrm{~N}$, R. $78 \mathrm{~W}$. According to Dunkle, this generic association is known only from the Mowry Shale in Wyoming and Montana. Thus, most of the Benton probably is Late Cretaceous in age, but the lower part is Early Cretaceous.

\section{NIOBRARA FORMATION}

The Niobrara Formation of Late Cretaceous age underlies small areas in the southern part of the quadrangle, but lithic details are generally obscured by soil, grass, and sage. Best exposures of the Niobrara occur along the north side of the Colorado River in sec. 11, T. 1 N., R. 79 W.

The total thickness of the Niobrara Formation in the quadrangle is not definitely known, but map relations and a measured section indicate that the Niobrara is about 550 feet thick. Elsewhere in Middle Park, Holt (1961) measured about 455 feet near Dillon, Colo.; Richards (1941) reported about 500 feet and Miles (1961) measured about 525 feet of Niobrara in the Kremmling area; Jenkens (1957) measured 410 feet of Niobrara in the Red Dirt Creek area north of Kremmling, Colo.; and Tweto (1957) estimated the Niobrara to be about 400 feet thick near Fraser, Colo. In North Park, Kinney and Hail (1959, p. 107) reported that the Niobrara ranges in thickness from 625 to 725 feet. Logs of wells drilled for oil and gas in the mapped area suggest the Niobrara to be about 500 feet thick, but this thickness is not entirely reliable owing to difficulty in picking the top of the Niobrara.

In general, the contact between the Benton Shale and the Niobrara Formation appears sharp, and in some areas in Colorado, according to W. A. Cobban (oral commun., 1963), it may be unconformable. Southeast of Hot Sulphur Springs along Heimbaugh Creek, brown-weathering fossiliferous limestone of the Benton (Juana Lopez equivalent) is sharply overlain by light-gray-weathering limestones and limy shale assigned to the Niobrara.

The lower 15-20 feet of the Niobrara is a distinctive unit where it was seen in the area, but poor exposure precluded mapping it separately. At Sunset Ranch, in the $S W 1 / 4$ sec. 11 , T. 1 N., R. 79 W., the lower unit consists of thin-bedded light-gray clayey limestone and marlstone whose fracture is subconchoidal, and laminated limy shale partings are interbedded in the limestone and marlstone. The lower unit is similar to the Fort Hays Limestone Member of the Niobrara Formation along the east side of the Front Range in Colorado. The upper part of the Niobrara, which probably correlates with the Smoky Hill Member of the Niobrara of the Front Range, consists of mediumto dark-gray subfissile limy shale and chalky limestone. X-ray diffractograms of Niobrara shale samples made by L. G. Schultz of the U.S. Geological Survey indicate that the shale consists mostly of calcite but contains mixed-layer clays that include some kaolin, illite, and chlorite and a few percent quartz (table 5). Near the top of the unit the shale contains many white specks that are probably coccoliths (Goodman, 1951).

The Late Cretaceous age of the Niobrara Formation is established by its stratigraphic position and its included fossils. Marine invertebrate fossils were found in the Niobrara along the road east of Heimbaugh Creek in SW $1 / 4$ sec. 12 , T. 1 N., R. 78 W., along the Sunset Ranch road in the $\mathrm{SE}_{1 / 4}^{1 / 3 e c}$ s. 10, T. 1 N., R. 79 $\mathrm{W}$., and in a roadcut along U.S. Highway 40 in the SW $1 / 4 \mathrm{NW}_{1}^{1} / 4$ sec. 10, T. 1 N., R. 79 W. W. A. Cobban identified the fossils as Ostrea congesta Conrad and Inoceramus sp. (fossil locs. 33-35, pl. 1). Fish scales and an arthropod fragment were also found in the Niobrara, but they are not diagnostic of age. In the Kremmling quadrangle in the $\mathrm{N} / 2 \mathrm{SE} 1 / 4$ sec. 32 , T. 1 N., R. $80 \mathrm{~W}$., Inoceramus aff. I. perplexus Whitfield and Ostrea sp. were found in limestone at the base of the Niobrara, which is probably equivalent to the Fort Hays Limestone Member, and Inoceramus erectus Meek and Ostrea sp. were found in limy shale about 85 feet above the base of the Niobrara. According to W. A. Cobban, the Inoceramus aff. I. perplexus Whitfield seems to be the same species that marks the lowest zone in the Fort Hays of the Front Range, and Inoceramus erectus Meek is characteristic of the second zone up in the Fort Hays of the Front Range.

The following measured section of the Niobrara is given to show a few details of the lithology.

Section of the Niobrara Formation in sec. 11, T. 1 N., R. $78 \mathrm{~W} . ;$ measured by G. A. Izett and A. M. Thompson, 1964; bedding N. $40^{\circ} \mathrm{W} ., 30^{\circ} \mathrm{NE}$.

Pierre Shale:

Thicknes s

12. Shale, olive-gray to black, locally limy; contact with underlying beds covered and gradational.

Niobrara Formation:

11. Shale, dark-brownish-gray to black, limy, speckled; interbedded with medium-gray thinly laminated chalky limestones; contains scattered fish scales; forms broad hogback..--

10. Partly covered, probably thinly laminated limy shale...

9. Covered, probably shale and limestone........

8. Partly covered; most float is light-gray limestone.

7. Partly covered; float is medium-gray flaggy limestone that weathers chalky white; contains traces of fossil debris; forms dip slope....... $\quad 10$

Thickness of Niobrara Formation._..... 545

Benton Formation (part):

6. Limestone, medium-brown, fairly coarse grained, thin-bedded, slabby, fetid; rich in fossil debris; contains Inoceramus, Scaphites, Prionocyclus; forms dip slope........ 
Section of the Niobrara Formation in sec. 11, T. 1 N., R. $78 \mathrm{~W}$.; measured by G. A. Izett and A. M. Thompson, 1964; bedding N. $40^{\circ} \mathrm{W}, 30^{\circ} \mathrm{NE}$-Continued

Benton Formation (part) - Continued

5. Partly covered, probably limy thin-bedded sandstone

4. Sandstone, light-gray (weathers orange brown), fine-grained; forms ledge

3. Sandstone, partly covered, orange-brown, finegrained, clayey, soft, thin-bedded, laminated;

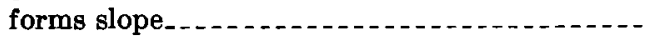

2. Sandstone, light-gray (weathers orange brown), fine- to medium-grained, thin-bedded, slabby, well-indurated; locally contains chert pebbles as much as $0.5 \mathrm{in}$. in diameter; forms hogback.

1. Covered, probably underlain by slope-forming shale that forms gumbo soil................

Partial thickness of Benton Formation.-.- -

Thickness ( ft)

15

3

The Pierre Shale of Late Cretaceous age underlies fairly extensive areas in the southern and eastern parts of the quadrangle. There it generally forms moderately steep grass-, sage-, and rubble-covered slopes beneath the bold cliffs of the Windy Gap Member of the Middle Park Formation. The main outcrops are along a narrow northwest-trending belt on the upthrown block of the Mount Bross fault; these outcrops extend for about 10 miles from the southeast corner of the quadrangle to the foot of Elk Mountain. Other outcrops of the Pierre are north of the Colorado River along the east edge of the quadrangle. An area along Heimbaugh Creek is inferred to be underlain by the Pierre.

The Pierre Shale is either truncated beneath an unconformity at the base of the Middle Park Formation or faulted against the Middle Park in most of the mapped area, and, accordingly, the thickness of the Pierre varies. No sections of the Pierre were measured because of poor exposure, but map relations and drillhole information indicate that the Pierre ranges in thickness from 0 to perhaps as much as 4,000 feet. Fossils from the upper 25 feet of the Pierre along Ute Bill Creek (fossil loc. 29, pl. 1) are probably from the Baculites cuneatus or $B$. reesidei zone, according to W. A. Cobban, and map relations indicate that these fossils occur at least 2,400 feet above the base of the Pierre. Undetected northwest-trending faults related to the Mount Bross fault may cause the Pierre to thin along Ute Bill Creek because, north of Boulder, Colo., along the east side of the Front Range, fossils from these zones are from 3,500 to 3,800 feet above the base of the Pierre (Scott and Cobban, 1965). Faunal evidence and thickness relations in the Kremmling quadrangle seem to indicate that preserved thicknesses of Pierre in Middle Park are similar to thicknesses of equivalent beds along the east side of the Front Range. Outside the mapped area in the Kremmling quadrangle, the Pierre has been reported to be 2,600 feet thick by Miles (1961) and almost 5,000 feet thick by Richards (1941). The writer measured the Pierre in the Kremmling quadrangle and determined the formation to be about 4,600 feet thick below the unconformity at the base of the Middle Park Formation.

In the mapped area the marine shales that form the upper part of the Niobrara Formation and the Pierre Shale are nowhere sufficiently well exposed to provide reliable stratigraphic information concerning the contact relations between the Pierre and the Niobrara. However, brief study of the contact relations near Kremmling, Colo., suggests that the Niobrara grades upward from gray limy speckled shale into dark-gray concretion-bearing Pierre Shale through many tens of feet. From the information gained in the Kremmling area, an inferred contact was drawn between the Niobrara and the Pierre along Heimbaugh Creek and, in sec. 10, T. 1 N., R. 79 W., in the Hot Sulphur Springs quadrangle, at the top of limy speckled shale in the Niobrara.

The lower part of the Pierre consists mostly of interbedded medium- to dark-gray shale and brownish-gray clayey siltstone and subordinate thin limestone beds. The shale is locally limy and contains a few scattered limy iron-stained siltstone concretions and septarian limestone concretions, some of which contain marine invertebrate fossils. X-ray diffractograms made of one sample of a concretion by L. G. Schultz indicate that it consists of clay (30 percent), quartz (12 percent), calcite (55 percent), and feldspar (2 percent) (table 5.)

TABLE 5.-Estimated percentages of minerals in some Cretaceous rocks

[M, montmorillonite; ML, mixed layer; I, illite; $\mathrm{CH}$, chlorite; K, kaolinite; P, plagioclase, A, alkali feldspar. Analyst, L. G. Schultz, U.S. Geol. Survey]

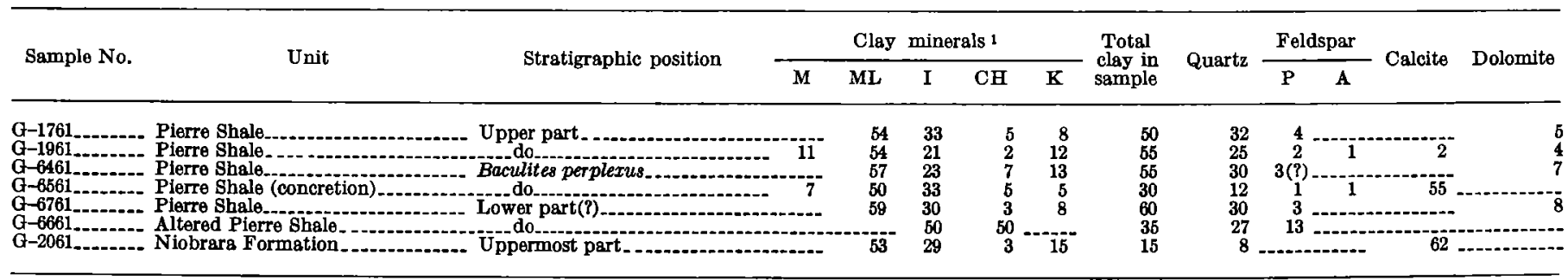

1 Percent of total clay. 
The upper part of the Pierre in the area consists chiefly of brownish-gray-weathering subfissile silty claystone and subordinate clayey siltstone, dark-gray shale, and thin impure limestone beds. Samples from the lower part of the Pierre were collected by the writer and studied by powder $\mathrm{X}$-ray methods by Schultz. The samples of the Pierre consist of clay (50-60 percent), quartz (25-32 percent), feldspar (2-4 percent), and mixed calcite and dolomite (5-8 percent) (table 5). Microscopic examination shows that the detrital grains are mainly elongate subangular quartz and plagioclase and some white mica, biotite, chlorite, and chert. The clay minerals are not well oriented. A few Foraminifera tests were seen in some thin sections of the rock.

A prominent silty sandstone bed in the Pierre forms a small hogback along the lower reaches of Ute Bill Creek. The bed, about 10 feet thick, is mappable for about 1 mile, but it seemingly grades laterally from ridge-forming thin-bedded sandstone to slope-forming siltstone and shale. The sandstone is very fine grained, has ripple marks and worm trails along bedding planes, and weathers brownish gray. This bed seems to mark the base of a sandy sequence of beds in the upper part of the Pierre. Several geologists have erroneously correlated this sandstone sequence and a similar sandstone one in the Pierre at Windy Gap just east of the quadrangle with the Fox Hills Sandstone. Fossils collected from below and above the sandstone along Ute Bill Creek by the writer and identified by W. A. Cobban indicate that the sequence occupies a lower stratigraphic position in the Baculites perplexus zone (fossil loc. 27, pl. 1). Fossils collected by W. A. Cobban G. R. Scott, and the writer from the sandstone sequence in the Pierre at Windy Gap indicate that they are from the B. scotti zone (W. A. Cobban, written commun., 1961). $B$. scotti occurs in the Hygiene Sandstone Member of the Pierre Shale along the northern Front Range foothills (Scott and Cobban, 1965).

From the earliest geological surveys to the present, many people including Marvine (1874, p. 167), Cross (1892, p. 205), Tollefson (1955), and Bombolakis (1958) have collected marine invertebrate fossils from the Pierre Shale outcrops that extend northwest from Cottonwood Pass to the foot of Elk Mountain. W. A. Cobban, W. T. Lee, T. S. Lovering, and G. R. Scott collected fossils from the Pierre in this area, and the unpublished information from their collections was kindly given to the writer. Table 6 lists the fossils found by them as well as those collected by the writer. The placement of the collections in the standard faunal zones of the Pierre Shale along the Front Range is based mainly on the genus Baculites. The fossil localities and a few inferred faunal-zone lines are shown on
TABLE 6.-Fossils from the Pierre Shale

[Cephalopod and pelecypod identification and zone assignment by W. A. Cobban, U.S. Geol. Survey; gastropod identification by N. F. Sohl, U.S. Geol. Survey]

\begin{tabular}{ccccc}
\hline $\begin{array}{c}\text { USGS } \\
\text { Mesozoic } \\
\text { locality }\end{array}$ & $\begin{array}{c}\text { Locality } \\
\text { on pl. 1 }\end{array}$ & Collector & Fossils & Zone
\end{tabular}

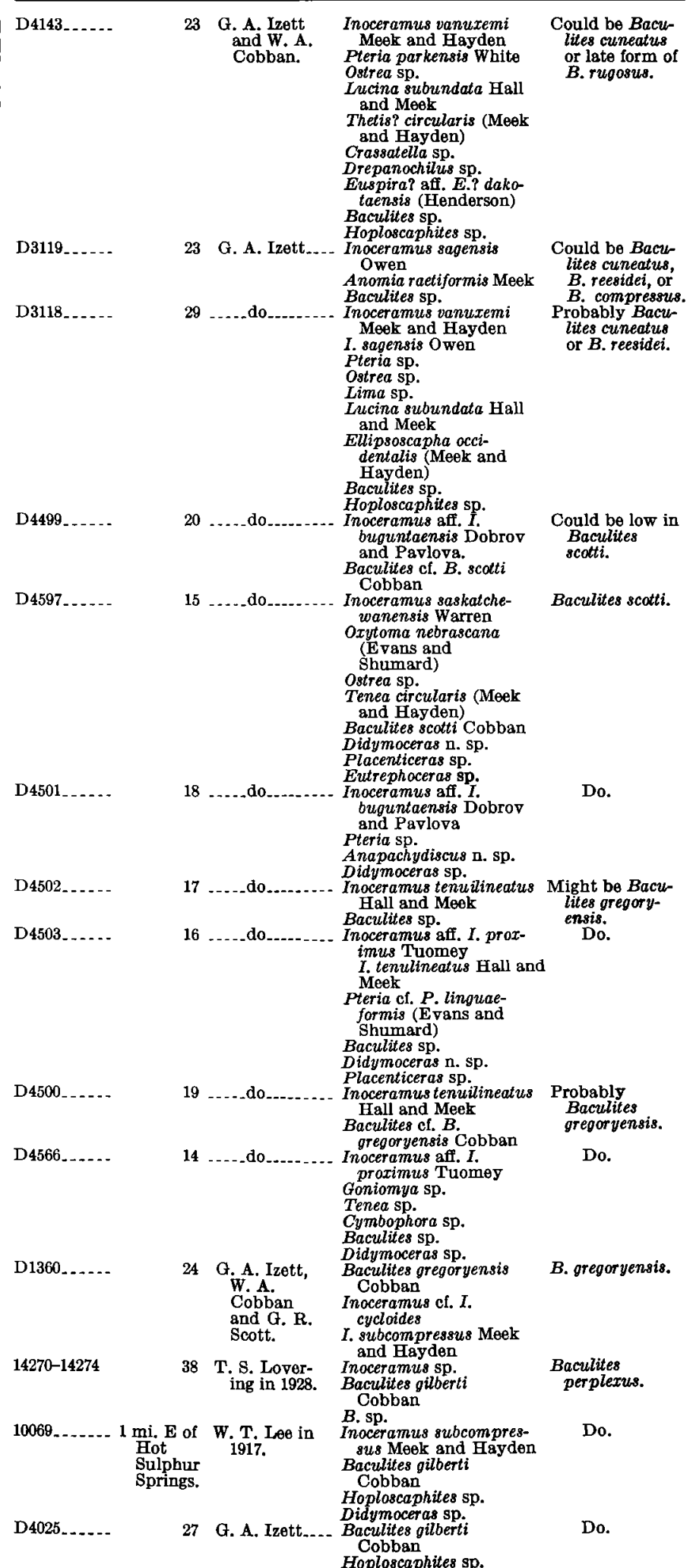


Table 6.-Fossils from the Pierre Shale-Continued [Cephalopod and pelecypod identification and zone assignment by W. A. Cobban U.S. Geol. Survey; gastropod identification by N. F. Sohl, U.S. Geol. Surveyl

\begin{tabular}{|c|c|c|c|c|}
\hline $\begin{array}{l}\text { USGS } \\
\text { Mesozolc } \\
\text { locality }\end{array}$ & $\begin{array}{l}\text { Locality } \\
\text { on pl. } 1\end{array}$ & Collector & Fossils & Zone \\
\hline D990_...... & 37 & $\begin{array}{l}\text { W. A. Cobban } \\
\text { and G. R. } \\
\text { Scott. }\end{array}$ & $\begin{array}{l}\text { Pteria sp. } \\
\text { Inoceramus subcom- } \\
\text { pressus Meek and } \\
\text { Heyden } \\
\text { Bacultites perplexus } \\
\text { Cobban }\end{array}$ & $\begin{array}{l}\text { Baculites } \\
\text { perplexus. }\end{array}$ \\
\hline D3122_...... & 28 & G. A. Izett...- & $\begin{array}{l}\text { Limatula sp. } \\
\text { Cuspidaria sp. } \\
\text { Baculites n. sp. }\end{array}$ & Do. \\
\hline D4498....... & 21 & ......do....... & $\begin{array}{l}\text { Inoceramus sp } \\
\text { Baculites perplexus } \\
\text { Cobban } \\
\text { Hoploscanhites so }\end{array}$ & Do. \\
\hline $\begin{array}{l}\text { D3120...... } \\
\text { D4024..... }\end{array}$ & 22 & 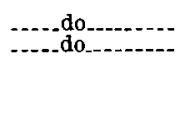 & $\begin{array}{l}\text { Inoceramus } \mathrm{n} \text {. sp. } \\
\text { Inoceramus sp. } \\
\text { Anomia sp. } \\
\text { Baculites asperiformis } \\
\text { Meak? }\end{array}$ & $\begin{array}{l}\text { Do. } \\
\text { Baculites asperi- } \\
\text { formis. }\end{array}$ \\
\hline D1359_...... & 25 & $\begin{array}{l}\text { W.A. Cobban } \\
\text { and G. R. }\end{array}$ & $\begin{array}{l}\text { Baculites mclearni } \\
\text { Landes }\end{array}$ & $\begin{array}{c}\text { Baculites } \\
\text { mclearni. }\end{array}$ \\
\hline D4144_..... & 36 & G. A. Izett.... & $\begin{array}{l}\text { Inoceramus sp. } \\
\text { Pteria sp. }\end{array}$ & Unknown. \\
\hline
\end{tabular}

the geologic map (pl. 1). The faunal-zone lines should ideally be drawn to limit the top and bottom of a zone, but because the number of collections is small the lines are drawn through the fossil localities. The oldest fossils found in the Pierre are probably from the $B$. mclearni zone, and they were found by W. A. Cobban and G. R. Scott just north of the Colorado River east of the Mount Bross fault. Successively younger baculite zones were found northeast of the $B$. melearni locality seemingly in normal stratigraphic order, but undetected faults in the Pierre may complicate the seemingly simple stratigraphic succession of faunal zones. The youngest marine fossils found in the quadrangle are from either the B. reesidei zone or the B. cuneatus zone, which are in about the middle of the Pierre along the east side of the Front Range near Littleton, Colo. (Scott, 1962, p. 16).

\section{MESOZOIC(P) AND TERTIARY ROCKS}

PORPHYRITIC AUGITE GYENITE AND TRACHYANDESITE

Plugs and dikes of porphyritic syenite intrude the Pierre Shale in the southeast corner of the quadrangle. The largest mass of syenite seems to have intruded an en echelon fracture zone that trends about $\mathrm{N} .45^{\circ} \mathrm{W}$. Plugs of syenite, roughly elliptical in plan, and a north-trending dike are satellitic to the en echelon dikes. The contact between the intrusives and the Pierre Shale seems to be very steep and sharp. Floworiented mafic minerals in the syenite near the contact plunge steeply. The Pierre is baked for several tens of feet adjoining the intrusives, and samples of baked shale were studied by X-ray methods by L. G. Schultz. The baked Pierre is generally harder than the unaltered Pierre Shale and shows a significant increase in plagioclase and chlorite and decrease in mixed-layer and kaolin clays (table 5, sample G6761).
The syenite is mottled medium greenish gray, is fine grained, and contains phenocrysts of pyroxene and feldspar. Thin sections show that the texture of the rock is hypidiomorphic granular and mainly fine grained. Most phenocrysts are nearly colorless fresh diopsidic augite $\left(\mathrm{n}_{\mathrm{y}}=1.700 ; 2 \mathrm{~V}_{\mathrm{z}}=54 \pm 2\right)$ as much as $5 \mathrm{~mm}$ long and contain inclusions of apatite, iron oxides, and nontronite(?) pseudomorphs after an unknown mafic mineral. The crystals are weakly zoned and rarely twinned. A few phenocrysts are resorbed zoned twinned plagioclase $\left(\mathbf{A} n_{35-50}\right)$ about 2 $\mathrm{mm}$ long, and some of these are jacketed by plagioclase. Inclusions of clinopyroxene, glass(?), and dust give the plagioclase a texture defined by Kuno (1950, p. 968) as honeycomb structure. The groundmass is euhedral to subhedral cloudy sanidine microperthite $\left(2 \mathrm{~V}_{\mathrm{x}}=46 \pm 2\right.$; optic plane $\left.\perp(010)\right)$. X-ray diffractograms imply that the sanidine is unmixed. After the sanidine was heated for 4 hours at $900^{\circ} \mathrm{C}, \mathrm{X}$-ray analysis suggested that the sanidine contained about 50 percent orthoclase molecule. A few sanidine phenocrysts have carlsbad twins and have small extinction angles on (010). Other groundmass minerals are lightorange-brown biotite, augite, and iron oxides. Alteration minerals include nontronite(?), analcite, stilbite, and clay. Accessory apatite is common. A modal analysis of the porphyritic syenite follows:

$\begin{array}{lr}\text { Alkali feldspar (sanidine) } & \begin{array}{c}\text { Volume } \\ \text { percent } \\ 45\end{array} \\ \text { Plagioclase_. } & 15 \\ \text { Pyroxene (diopsidic augite) } & 12 \\ \text { Biotite. } & 1 \\ \text { Nontronite(?) } & 4 \\ \text { Zeolites (analcite and stilbite) } & \\ \text { Iron oxides_. }\end{array}$

Small plugs and dikes of porphyritic trachyandesite cut the Pierre Shale along Ute Bill Creek. The plugs and dikes are more resistant to erosion than the Pierre and form small knobs projecting above the soft shale slopes. One small plug of trachyandesite in the $\mathrm{W} / 2$ sec. 34 , T. 2 N., R. 78 W., is brecciated near its contact with baked Pierre Shale.

The trachyandesite is dark gray to dark brownish gray and has scattered phenocrysts of clinopyroxene and oxyhornblende. Locally, amygdules as much as 1 inch in diameter are filled with natrolite or calcite. Under the microscope, thin sections of the rock show felty to flow-oriented texture. Phenocrysts are plagioclase $\left(\mathrm{An}_{40-56}\right)$, augite $\left(2 \mathrm{~V}_{\mathrm{z}}=55-58 ; \mathrm{n}_{\mathrm{y}}=1.700 \pm .002\right)$, biotite, and oxyhornblende along with iron-oxide ghosts of mafic minerals. The groundmass is mainly normally zoned plagioclase $\left(\mathrm{An}_{35-50}\right)$ laths and some augite, alkali feldspar, and iron oxides. Accessory baked apatite phenocrysts that show pseudopleochroism and acicular apatite are common. Alteration minerals 
include analcime, calcite, natrolite, quartz, and nontronite(?).

The syenite and trachyandesite are possibly of Cretaceous age. The syenite and trachyandesite plugs and dikes are clearly younger than the Pierre Shale which they cut. The plugs and dikes are interpreted to be about the same age as the Cretaceous(?) Windy Gap Volcanic Member of the Middle Park Formation because breccia fragments in the Windy Gap are similar petrographically to samples of some of the plugs and dikes. The dikes of syenite may have intruded undetected northwest-trending tensional faults in the Pierre Shale in the upthrown block of the Mount Bross fault (N. $30^{\circ}-50^{\circ} \mathrm{W}$.) in Late Cretaceous time and may have been the source for some of the volcanicrock fragments in the Windy Gap Member.

\section{MIDDLE PARK FORMATION}

The Middle Park Formation is made up of coarse intermontane basin-fill deposits that collected during Late Cretaceous(?) and early Tertiary time in the southern part of a large north-trending structural depression known as North-Middle Park basin. The Middle Park Formation is at least 6,000 feet thick in Middle Park, and it reflects the rise and erosion of the Front and Park Ranges which lie to the east and west. In some areas of Middle Park the formation seemingly rests with little structural discordance on the eroded top of the marine Pierre Shale, but in other areas the formation truncates all the Mesozoic rocks and rests unconformably on the Precambrian rocks. Relief on this unconformity, which is locally large, divides Middle Park basin into smaller basins and makes correlation between the lithologically varied rocks in these smaller basins difficult.

In the northern part of North-Middle Park basin, rocks that are in part correlative with the Middle Park
Formation were named the Coalmont Formation by Beekly (1915). These rocks are being studied by D. M. Kinney and W. J. Hail, Jr., of the U.S. Geological Survey. Rocks that Kinney (oral commun., 1964) includes in the Coalmont Formation seemingly extend for a short distance into the northern part of the quadrangle east of Willow Creek. The writer did not separate the Coalmont equivalent from the Middle Park Formation in the mapped area because the area is heavily timbered, the rocks are not well exposed, and stratigraphic relations are uncertain.

The rocks here included in the Middle Park Formation were first mapped by Marvine (1874) of the Hayden Survey; he applied the informal name "lignitic formation" and supposed that they were equivalent to unnamed lignitic beds (Laramie Formation) of "as yet disputed age" east of the Front Range. Later, Cross (1892) recognized that the rocks included in Marvine's "lignitic formation" were not equivalent to the Laramie Formation but that they correlated in general with the Denver Formation. Emmons (1890, p. 281), Clark (1891, p. 137), Cross (1892), and Eldridge (1901) used the name Middle Park for Marvine's "lignitic formation" in Middle Park, but they gave no type section or area for the unit. Since that time, most geologists who have worked in the area have accepted Cross' correlation of the Middle Park Formation with the Denver Formation.

The Middle Park Formation is the bedrock over large areas in the quadrangle, and it forms moderately steep slopes separated by some fairly continuous ledgeand cliff-forming units. In much of the area underlain by the Middle Park Formation, large-scale structural features are outlined by these resistant ledge- and cliffforming units. The form of one of the large-scale structural features, the Breccia Spoon syncline (fig. 7),

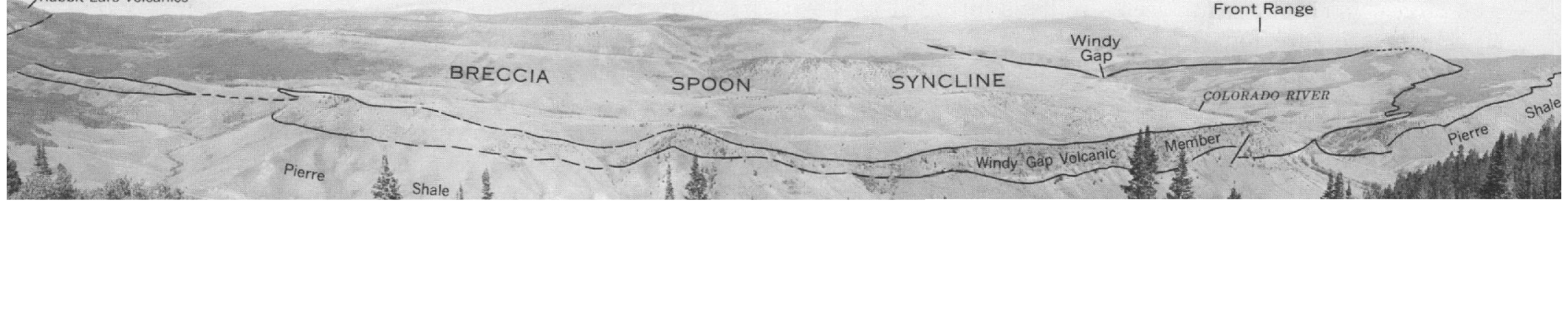

Figure 7.-Breccia Spoon syncline and Elk Mountain in panoramic view looking northeast from Mount Bross. Windy Gap Volcanic Member of the Middle Park Formation outlines shape of the syncline. At Elk Mountain the Rabbit Ears Volcanics rests unconformably on the upturned edges of the Middle Park Formation. 
is remarkably well outlined by ridge-forming units. At lower altitudes along the Colorado River, the Middle Park Formation supports only sage and grasses and a few scattered evergreens, but in the uplands it supports dense growths of lodgepole pine and some Engelmann spruce, alpine fir, Douglas-fir, and limber pine.

The Middle Park Formation locally contains a distinctive mappable unit of fragmental andesitic and trachyandesitic volcanic rock, the Windy Gap Volcanic Member, and a stratigraphically higher unit of fragmental andesitic rock, the breccia of Marietta Creek. These rock units are described after the general discussion of the formation. Other informal members of the Middle Park Formation are shown on plate 1. Informal units of the Middle Park Formation above the Windy Gap Volcanic Member locally form prominent ledges and cliffs that can be traced in a general way in the Breccia Spoon syncline, and they are shown on the map to better outline the structure of the rocks; they are not strictly mappable stratigraphic units, nor do they hold close stratigraphic position in the Middle Park Formation.

Lenticular beds of conglomeratic sandstone and grit make up the greater part of the Middle Park Formation. They are commonly slabby, thick bedded to massive, and poorly sorted, and they weather to somber tones of gray and brown. The sandstone varies widely in grain size from very fine to very coarse grained and contains stringers and randomly scattered granules, pebbles, and cobbles. In the Breccia Spoon syncline and along Blue Ridge the sandstone locally contains boulders of pink granite as much as 3 feet in diameter. A few miles northeast of the quadrangle along the north side of Willow Creek near the Vagabond Ranch, Middle Park sandstones are well exposed and contain rounded boulders of pink granite as large as 6 feet in diameter (fig. 8). In the lower part of the Middle Park Formation along State Highway 125 and in railroad cuts in sec. 28, T. 2 N., R. 77 W., sandstone flow rolls similar to those described by Pepper, de Witt, and Demarest (1954, p. 88) formed where thick massive andesitic sands slumped, sank, and then flowed into water-saturated andesitic muds. These sandstones show ellipsoidal shapes, deformed bedding, and faults. Most of the finer grained sandstones show small-scale low-angle cross-laminations that are useful in determining tops of bedding along the Mount Bross fault. The crosslaminations are slightly concave and are marked by thin concentrations of dark minerals including magnetite, clinopyroxenes, and hornblende that contrast sharply with the light grays and browns of the sandstone matrix. A few mudcracks and leaf impressions

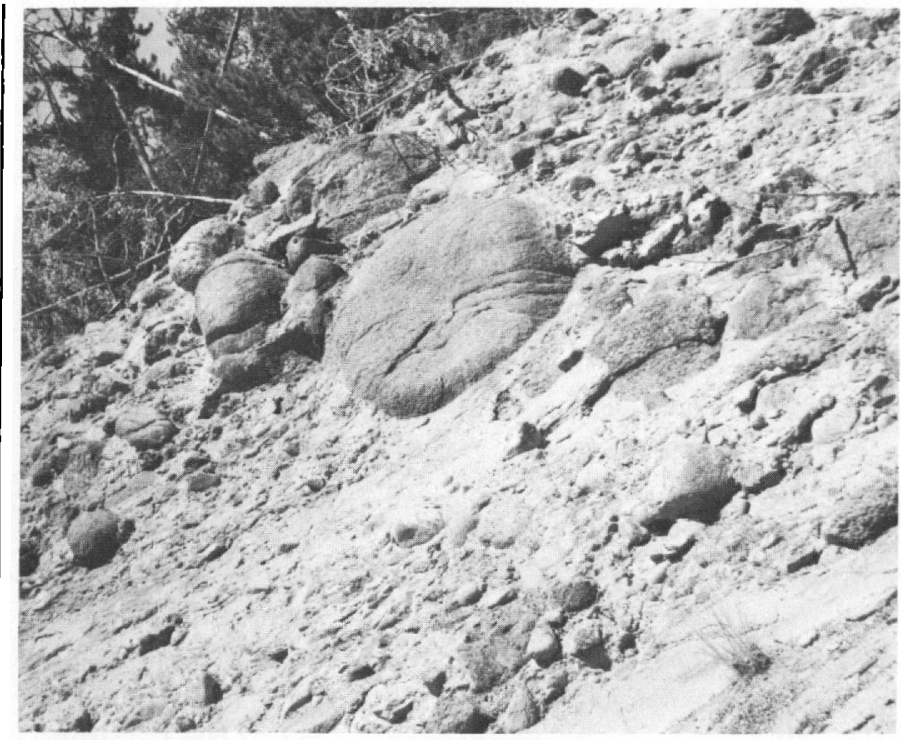

Frgdre 8.-Large boulders of pink granitic rock of Precambrian age in Middle Park Formation near Vagabond Ranch along Willow Creek. Large boulder in center is about 6 feet in diameter. Photograph by A. A. Wanek.

were seen along bedding planes of the fine-grained sandstones.

The sandstone and grit in the Middle Park Formation are composed of rounded rock fragments, broken crystals and rounded mineral grains, and matrix. They are everywhere arkosic in the sense that they contain large proportions ( $>30$ percent) of either oscillatoryzoned twinned plagioclase derived from the erosion of Laramide hypabyssal intrusives or alkali feldspar and weakly zoned plagioclase derived from the erosion of Precambrian crystalline rocks. The rock fragments in the sandstone and grit range in size from granules to large boulders, and they are well rounded to subangular. Most of the rock fragments consist of (1) dark-purplishgray, purplish-red, dark-greenish-gray, and gray porphyritic andesitic rocks of probable Late Cretaceous to early Tertiary age; (2) light-gray porphyritic felsic igneous rocks of probable Late Cretaceous to early Tertiary age; and (3) granitic and gneissic rocks of Precambrian age. The proportions of these rock fragments in the Middle Park Formation show marked vertical and lateral changes over short distances. Pebble counts show that mainly the andesitic rock fragments occur in largest amounts in the lower part of the Middle Park in the Breccia Spoon syncline and east of Beaver Creek along Blue Ridge. The felsic porphyritic rock fragments are most common in the upper part of the formation in the Breccia Spoon syncline and at Mount Bross. In general, above the Windy Gap Member the number of rounded clasts of Precambrian crystalline rocks increases upward. Where 
the Middle Park Formation truncates Mesozoic sedimentary rocks, the basal sandstones of the formation contain chert pebbles and sandstone blocks of the Dakota as much as 1 foot on a side.

Sandstone and grit, especially in the lower part of the Middle Park Formation above the Windy Gap Member in the Breccia Spoon syncline, probably had a matrix of altered andesitic mud. Diagenetic alteration of the andesitic mud produced clay, zeolites, and silica. These constituents make some of the sandstone and grit well indurated. West of Byers Canyon many beds of sandstone and grit in the lower part of the formation have an entirely different aspect: the beds contain little andesitic material and some beds are not well indurated; the sandstone is arkosic and gritty and weathers to rounded ledges. These friable gritty arkosic sandstones of the Middle Park Formation are lithically similar to some rocks included in the Coalmont Formation of North Park.

Mineral grains in samples of the sandstone and grit, listed in approximate order of decreasing abundance, are feldspars (microcline and strongly zoned plagioclase), quartz, muscovite, hornblende, pyroxene, biotite, and magnetite. Heavy minerals separated from the sandstones and grits are listed in table 10 and discussed on page 58 .

The mudstone in the Middle Park Formation is varicolored in somber hues of olive green and gray and, rarely, reddish brown. 'The mudstone is micaceous (muscovite), poorly bedded, and structureless and commonly forms grass- and sage-covered slopes. Carbonized logs and seams of carbonaceous trash are interbedded with mudstone and other fine-grained rocks in the Middle Park Formation in roadcuts east of Parshall. Carbonaceous shale occurs in the lower part of the Middle Park Formation in the southwest quarter of the mapped area.

Patterns of sedimentation in the lower part of the Middle Park Formation were influenced in part by ridges of crystalline rocks of Precambrian age that projected above the floor of the southern part of the Middle Park basin during early Middle Park time. One such ridge of Precambrian rock that extends from Rock Creek to east of Byers Canyon has as much as 1,000 feet of relief in less than 2 miles and acted as a barrier that separated a northeastern from a southwestern basin of sedimentation during deposition of the Middle Park Formation. The northeastern basin, which includes the Breccia Spoon syncline, was fed with material rich in andesitic debris shed from volcanic centers that were active in Laramide time. The lower part of the formation in the Breccia Spoon syncline and along Blue Ridge was deposited in this northeastern basin and is characterized by large amounts of andesitic breccia and conglomerate (Windy Gap Member and breccia of Marietta Creek) that grade upward into well-indurated andesitic conglomerate, sandstone, grit, and mudstone. In the southwestern basin of deposition the lower part of the Middle Park consists of micaceous arkosic conglomerate mixed with small amounts of andesitic debris that contrast sharply with the andesite-rich rocks east of the ridge. Along a line that extends from Hot Sulphur Springs to the head of Heimbaugh Creek, the lower part of the Middle Park that is rich in andesitic rock fragments laps onto the Precambrian ridge that extends from Rock Creek to east of Byers Canyon and grades laterally into rocks composed principally of granitic debris.

The Middle Park Formation covered much of Middle Park in early Tertiary time, but the preserved thickness of the formation varies markedly because the formation covers an erosion surface with considerable relief and because the upper part of the formation has been removed by erosion. The preserved thickness of the Middle Park Formation is greatest in the Breccia Spoon syncline north of the Colorado River in an area that originally was underlain by the thickest part of the formation. The writer and A. A. Wanek measured about 6,600 feet of Middle Park along State Highway 125 , and a description of the measured section is given at the end of the discussion of the Middle Park. Tollefson (1955) measured about 5,000 feet of Middle Park across the Breccia Spoon syncline where Marvine $(1874$, p. 156) had estimated the formation to be about 5,500 feet thick.

The lower contact of the Middle Park Formation is well exposed at several places in the quadrangle. Because the formation was deposited on deformed older rocks, it rests on rocks of widely different ages. In the Breccia Spoon syncline the formation rests unconformably, but with only slight angular discordance, on the Pierre Shale. Near Cottonwood Pass in sec. 16, T. 1 N., R. 77 W., the Middle Park rests on the Baculites gregoryensis zone of the Pierre Shale, but north along the contact the Middle Park rests on successively younger parts of the Pierre. The contact in this area is sharp and is marked by a few feet of reworked Pierre Shale overlain by poorly sorted fragmental volcanic breccias of the Windy Gap Member. Locally at the base of the breccias, conglomerates rich in Precambrian granitic rock mark the contact. The conglomerates that contain rounded Precambrian rocks at the base of the Windy Gap show that the sedimentary cover had been stripped from parts of the area before deposition of the Middle Park Formation began. Westward from the Mount Bross fault the Middle Park truncates successively older Mesozoic sedimentary rocks and 
laps onto the Precambrian granitic rocks in Byers Canyon. The truncation of the Mesozoic rocks by the Middle Park Formation is well exposed at outcrops at the head of Byers Canyon along the tracks of the Denver and Rio Grande Western Railroad (fig. 9), where the Middle Park rests with marked angular unconformity on the truncated edge of the Dakota Sandstone. The Middle Park overlies the lower part of the Pierre Shale in the western part of the quadrangle in the northern part of sec. $10, T .1 \mathrm{~N} ., \mathrm{R} .79 \mathrm{~W}$. and the contact is well exposed at the head of several small gullies. The contact is sharp and is marked by brownish-gray silty shale of the Pierre overlain by coarse arkosic conglomerates of the Middle Park Formation, which contain boulders of Precambrian granitic rocks as much as 3 feet on a side. There appears to be little angular discordance at this place, for the Middle Park has the same general attitude as the Pierre Shale.

The Late Cretaceous(?) and Paleocene age of the Middle Park Formation is based on its stratigraphic position (post-Pierre); its included fossil leaves, pollen, and spores; and its lithologic correlation with the Denver Formation of Late Cretaceous and Paleocene age on the east side of the Front Range. The formation was assigned a Cretaceous or Eocene age by Marvine (1874), a post-Laramie age and correlated with the Denver Formation by Cross (1892, p. 212-213), an Eocene age by Knowlton (1930, p. 5-11), a Paleocene age by Brown (1949), and a Late Cretaceous and Paleocene age by Lovering and Goddard (1950, p. 40) and Izett, Taylor, and Hoover (1963). The doubt about the age of the formation as indicated by the foregoing age assignments apparently stems from (1) conflicting interpretations of the age of the fossil leaves, pollen, and

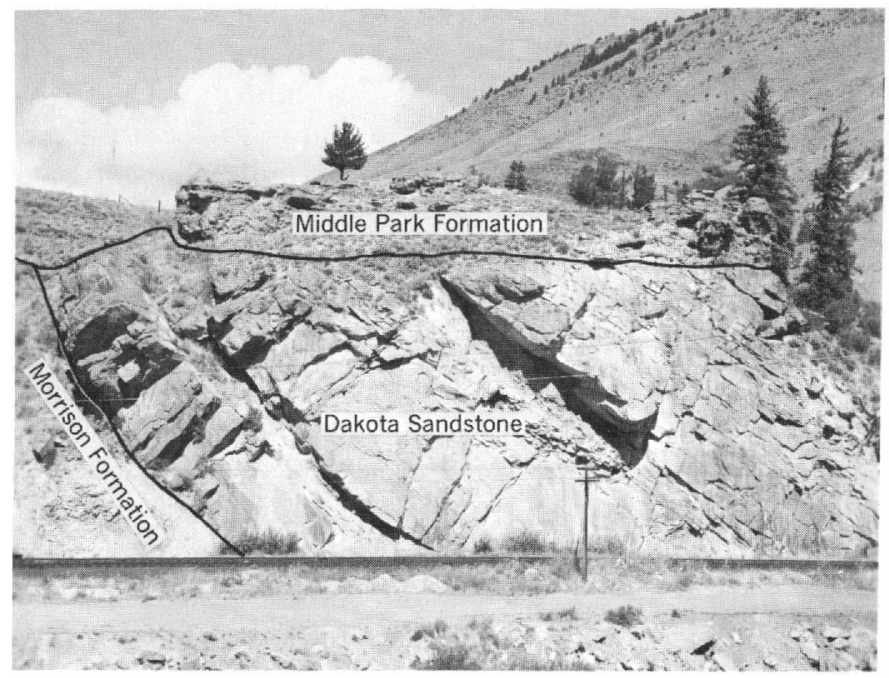

Figure 9.-Middle Park Formation resting with angular unconformity on Dakota Sandstone at the east end of Byers Canyon. spores; (2) the uncertainty about the amount of time represented by the unconformity that separates the Middle Park Formation from the older rocks; and (3) the probability that the age of the formation at its base may not be the same everywhere owing to the considerable relief upon which the formation was deposited.

Fossil leaves have been collected in the mapped area by several geologists in the past and according to Knowlton (1930) they indicate a Paleocene age. The writer collected fossil leaves from the Middle Park, and the locations of the few small collections are shown on the map (pl. 1). The leaves, which were identified by J. A. Wolfe of the U.S. Geological Survey, include Platanus raynoldsi (fossil loc. $13, \mathrm{pl} .1$ ), Platanus ef. $P$. raynoldsi and Viburnum magnum (fossil loc. 9, pl. 1), and Amperopsis acerfolia (fossil loc. 11, pl. 1). According to Wolfe, the leaves indicate a Paleocene age.

Samples of carbonaceous claystones and impure coal beds were collected from the Middle Park Formation for pollen and spore analysis by Louise Weiler and the writer, and the locations of the samples are shown on plate 1. The following list gives some of the more significant forms found by R. H. Tschudy of the U.S. Geological Survey:

Fossil locality 7

Momipites sp.

Triatriopollenites sp.

According to Tschudy (written commun., 1963), these forms indicate a Paleocene age.

Fossil locality 8

Momipites sp.

Carayapollenites sp.

Triatriopollenites sp.

According to Tschudy (written commun., 1963), these forms indicate a Paleocene age.

Fossil locality 10

Proteacidites sp. (54 percent of the sample)

According to Tschudy (written commun., 1962), "The high percentage of Proteacidites (54 percent) and the absence of species characterizing Paleocene sediments is our basis for this determination. The assemblage compares favorably with those from the upper Lance and Adaville Formations of Late Cretaceous age."

Fossil locality 20

Triatriopollenites sp.

Carayapollenites sp.

According to Tschudy (written commun., 1962), the assemblage "compares favorably with the pollen assemblage from the Paleocene part of the Evanston Formation of Late Cretaceous and Paleocene age from near Kemmerer, Wyo."

One sample collected about 100 feet above the Windy Gap Member (fossil loc. 10, pl. 1) contains pollen and spores that, according to Tschudy, indicate a Late 
Cretaceous age. On the basis of this sample, Izett, Taylor, and Hoover (1963) assigned a Late Cretaceous age to the Windy Gap Member. Other samples that contained pollen and spores (fossil loc. 8, pl. 1) taken from about the same stratigraphic position in the Middle Park Formation as the Late Cretaceous locality contain pollen that, according to Tschudy, indicates a Paleocene age. In view of the somewhat conflicting paleobotanical age determinations and until diagnostic vertebrate fossils can be found, a Late Cretaceous(?) and Paleocene age is assigned to the Middle Park Formation. In North Park, beds included in the Coalmont Formation that may be partly equivalent to beds in the upper part of the Middle Park Formation contain pollen and spore assemblages that indicate an Eocene age (Hail and Leopold, 1960), perhaps early Eocene. The possibility exists that the upper part of the Middle Park Formation in Middle Park may also be of Eocene age, but no samples have as yet yielded Eocene pollen and spores.

\section{WINDY GAP VOLCANIC MEMBER}

The Windy Gap Volcanic Member of the Middle Park Formation (Izett and others, 1963) is a distinctive sequence of andesite and trachyandesite volcanic breccia and conglomerate at the base of the Middle Park Formation that probably formed from the destruction of andesitic volcanic domes that were active in and along the east margin of the North-Middle Park basin in Late Cretaceous and early Tertiary time. The member accumulated along the deeper, eastern part of the North-Middle Park basin from near Fraser to at least the head of Willow Creek. In the quadrangle the member forms bold cliffs and ridges that outline a large open north- to northwest-plunging syncline that Marvine (1874) named the "Breccia Spoon" in reference to the spoon-shaped physiographic form of the plunging syncline (fig. 7). The member generally forms the basal unit of the Middle Park east of a line that extends northwest from the head of Heimbaugh Creek through the west edge of Hot Sulphur Springs to the head of Ute Bill Creek. Along the line the member grades laterally into the arkosic conglomerates; this gradation is particularly well shown in sec. 13, T. 1 N., R. 78 W. West of this line the base of the Middle Park consists of coarse arkosic conglomerates containing only small amounts of fragmental andesitic debris that cannot consistently be separated from the upper part of the Middle Park. The Windy Gap pinches out into andesitic mudstones and conglomerates within the Breccia Spoon syncline in sec. 27, T. 2 N., R. 78 W. (pl. 1). Elsewhere in the region the member was mapped in the Bottle Pass quadrangle by R. B. Taylor, and it was traced by the writer to the north as far as Willow Creek in the
Bowen Mountain quadrangle. It may extend as far north as the Illinois River in the southeast corner of the Jack Creek Ranch quadrangle in North Park. Along the Illinois River, andesitic conglomerates and breccia that form a sharp ridge may be equivalent to the Windy Gap Member.

The Windy Gap ranges in thickness from 0 to 1,100 feet in the area, but it averages about 600 feet in much of the area. The member is about 625 feet thick $1 \frac{1}{2}$ miles northeast of Hot Sulphur Springs, but it thins markedly to the northwest. Near Cottonwood Pass the member is about 600 feet thick, and where Willow Creek cuts through the member it is about 650 feet thick. At Windy Gap the member is about 1,100 feet thick; however, it includes in the upper part several hundred feet of volcanic sandstone and conglomerate that could very well be included with the rest of the Middle Park Formation. Owing to the great amount of volcanic-derived material in the sandstone and conglomerate, these were arbitrarily included in the Windy Gap.

The Windy Gap consists chiefly of complexly intercalated well-indurated massive volcanic breccia and conglomerate and subordinate amounts of volcanic sandstone and mudstone. Volcanic breccia forms a large part of the member, and it is well exposed in the roadcut at Windy Gap (fig. 10). The breccia is composed of variable amounts of angular to subrounded fragments of andesite and trachyandesite, which range in size from coarse ash to blocks as much as 5 feet in diameter, set in a fine-grained matrix that contains broken crystals of feldspar, pyroxene, hornblende, and biotite. Rock fragments other than volcanics are rare, but locally boulders of Precambrian granitic rocks as much as 2 feet in diameter and some granules and sandsized grains of microcline and quartz occur near the base of the member at Windy Gap and in areas where the member is thin. Volcanic conglomerate locally forms massive beds in the Windy Gap, and it consists of subangular to well-rounded pebbles, cobbles, and boulders of andesite and trachyandesite set in a matrix of andesitic mudstone. Sorting and stratification within the member are extremely variable. In some areas the upper third of the member is fine grained and well sorted and ranges from thin to thick bedded; the lower two-thirds is very poorly bedded and sorted. Along the strike the upper part may grade to massive poorly bedded chaotic breccias and conglomerates, and the lower part may show incipient sorting and stratification. According to R. B. Taylor (oral commun., 1961), lava flows occur in the Windy Gap in the adjacent Bottle Pass quadrangle, but none were recognized in the Hot Sulphur Springs quadrangle. 


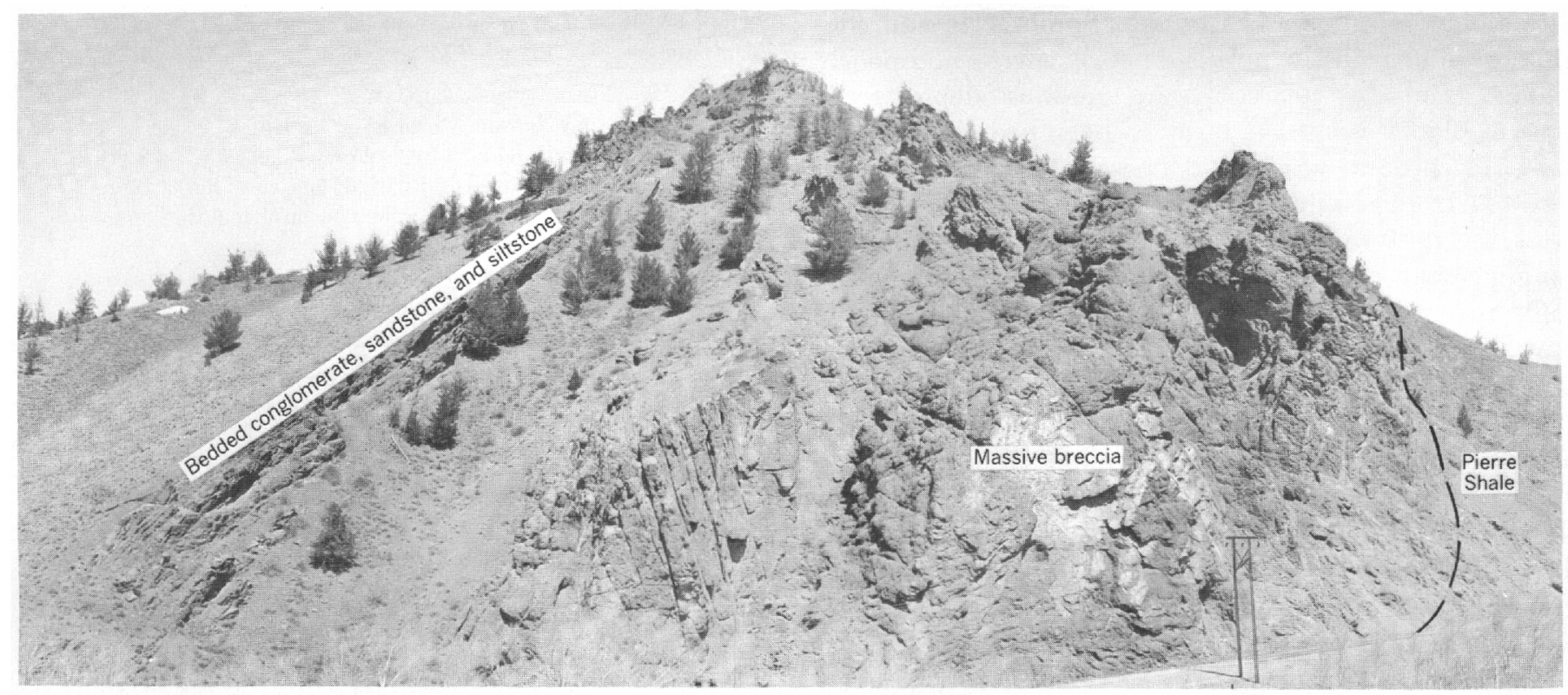

Figure 10.-Windy Gap Volcanic Member of the Middle Park Formation at Windy Gap, showing lower, massive breccia and upper, bedded conglomerate, sandstone, and siltstone beds. Zeolites coat joint surfaces in breccia beds. Photograph by $\mathbf{R}$. B Taylor.

The volcanic rock fragments in the Windy Gap are composed of several types of andesite and trachyandesite, and the porphyritic varieties are distinguished by differences in abundance and mineralogy of phenocrysts. A few fragments were tentatively identified as porphyritic trachyte. The typical groundmass of many fragments consists chiefly of zoned plagioclase $\left(\mathrm{An}_{\mathbf{4 0 - 5 0}}\right)$, diopsidic augite, and magnetite and includes small amounts of hornblende and biotite. A few fragments contain some microcrystalline or cryptocrystalline alkali feldspar. The groundmass may be felty or trachytic, and it ranges from microcrystalline to fine grained. Phenocrysts as much as $5 \mathrm{~mm}$ in diameter may form as much as a third of the porphyritic varieties. The phenocrysts, a few of which are albitized or show honeycomb structure, are mainly subhedral to euhedral zoned plagioclase $\left(\mathrm{An}_{40-65}\right)$ and euhedral diopsidic augite $\left(2 \mathrm{~V}_{z}=53-55\right)$; other phenocrysts seen in a few samples are oxyhornblende, common hornblende, quartz, alkali feldspar, and biotite. Iron-oxide ghosts after hornblende are common. Alteration minerals in the rock fragments include zeolites (analcime, heulandite, stilbite, and phillipsite(?)), nontronite(?), celadonite, chlorite, calcite, limonite, and quartz.

The upper contact of the Windy Gap is gradational and is chosen arbitrarily. The volcanic rocks and sedimentary rocks containing volcanic fragments grade upward into grits that contain a fairly high percentage of large Precambrian granitic pebbles plus microcline, quartz, and muscovite granules. The contact was gener- ally set at the lowest occurrence of large amounts of Precambrian granitic rock and microcline fragments. Olive-gray and yellowish-brown siltstone and claystone as well as thin discontinuous limestone and poorquality lignitic coal beds overlie the member at Windy Gap. Silicified logs, casts of Equisetum, and a fragment of fern pinnules were found near the top of the Windy Gap southwest of Sheriff Creek in sec. 36, T. 1 N., R. 78 W., and in sec. 10, T. 1 N., R. 77 W. According to R. A. Scott (written commun., 1961), who identified the fossils, these fossils are not diagnostic of age.

\section{BRECGIA OF MARIETTA CREEK}

A lens of andesitic volcanic breccia and conglomerate 0 to about 200 feet thick is enclosed in the lower part of the Middle Park Formation above the Windy Gap Member north of Marietta Creek in the Breccia Spoon syncline. The distribution of the unit is shown in plate 1 . The breccia and conglomerate unit lies about $300-400$ feet stratigraphically above the Windy Gap Member along Marietta Creek. The unit, which generally forms a ridge, can be traced north from Marietta Creek to a point about 2 miles north of the Colorado River along Smith Creek, and there it grades laterally into volcanic mudstones and sandstones in the lower part of the Middle Park.

The general aspect of the unit is similar to that of the breccia and conglomerate in the Windy Gap Member except that locally the breccia fragments in the unit contain more green celadonite and red heulan- 
dite along fractures and in vugs. The breccia and conglomerate beds in the unit are poorly sorted and poorly bedded, and they probably are mudflow deposits. At several places along the outcrop belt, beds in the unit show discordant attitudes. These attitudes probably resulted from slumps that formed during and shortly after the unit was deposited. The beds of breccia and conglomerate are locally interbedded with varicolored tuffs and volcanic sandstones, and in these areas the unit can be separated only arbitrarily from the other sandstones of the Middle Park.

The petrographic character of the fragments in the breccia and conglomerate is similar to that of the volcanic fragments in the Windy Gap Member, and they must have had similar sources. The fragments are dark-greenish-gray, purplish-red, grayish-purple, and gray porphyritic biotite-hornblende-pyroxene andesite and trachyandesite.

Section of Windy Gap Volcanic Member of the Middle Park Formation in the NE1/4SW1/4 sec. $35, T .2 N ., R .78 \mathrm{~W}$.

[Measured by G. A. Izett and R. R. Cunningham]

Middle Park Formation:

Thickness

7. Mudstone, dark-yellowish-brown, volcanic; intercalated with conglomerates consisting of rounded pebbles and cobbles of granitic rocks of Precambrian age; forms slopes....

Windy Gap Volcanic Member:

6. Breccia and conglomerate, volcanic, poorly sorted and bedded, massive; clasts are subangular to rounded porphyritic augite andesite and are as much as $3 \mathrm{ft}$ in diameter; calcite, heulandite, and stilbite coat fractures; breccia decreases in upper part of unit; sorting and bedding better in upper part; matrix grayish olive; lower contact an erosion surface with as much as $15 \mathrm{ft}$ of local relief ; forms massive cliff

5. Sandstone and siltstone, light-olive-gray (weathers pale olive gray), volcanic, spheroidal-weathering, massive, moderately well bedded; forms conspicuous local marker bed; joints trend roughly north; forms ledges and slopes.........................

4. Breccia, poorly sorted and bedded, volcanic; matrix light olive gray; clasts mostly subangular to subrounded, multilithologic and multicolored, and as large as $2 \mathrm{ft}$ in diameter; most fragments porphyritic augite andesite; calcite coats fractures; intercalated with volcanic siltstones and sandstones in lower part; forms ledges and slopes.

3. Siltstone, light-olive-gray, volcanic, fairly well bedded, massive, spheroidal-weathering, well-indurated; contains a few scattered andesite fragments as much as 2 in. in diameter; calcite and zeolites fill fractures; forms ledges.
Section of Windy Gap Volcanic Member of the Middle Park Formation in the NE1/4WW1/4 sec. $35, T .2 N$., R. 78 W.-Con.

Middle Park Formation-Continued

Windy Gap Volcanic Member-Continued

2. Breccia, generally poorly bedded, poorly sorted, well-indurated; matrix light olive gray; contains volcanic multicolored porphyritic andesite fragments as large as 18 in. in diameter; fragments subrounded to subangular; contains some even-bedded volcanic siltstone and sandstone units; forms

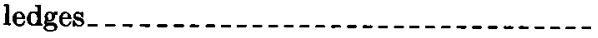

Thickness of Windy Gap Volcanic Member-..........

Pierre Shale:

1. Siltstone, partly covered, olive-gray, clayey, subfissile; contact with Middle Park Formation is covered but can be picked within $10 \mathrm{ft}$; forms slope.

Section of the Middle Park Formation along Colorado State Highway 125 northwest from Gold Run

[Measured by G. A. Izett and A. A. Wanek, 1962]

Middle Park Formation (upper part) :

11. Sandstone, partly covered, light-olive-gray to yellowish-brown, very fine grained to coarse-grained, micaceous, arkosic, lenticular; contains a few loadcasts; locally granulitic and conglomeratic and contains pebbles of Precambrian granitic rocks and felsite porphyry as much as 6 in. in diameter; interbedded with medium-olive-gray clayey micaceous siltstone; forms slopes and ledges.............................

10. Sandstone, partly covered, pale-reddishbrown, very fine grained to coarsegrained, micaceous, arkosic, lenticular, massive-weathering, thin- to thick-bedded; matrix pale olive green; locally conglomeratic and contains pebbles of felsite porphyry and Precambrian granitic rocks; forms ledges.........................

9. Sandstone, partly covered, light-olive-gray to yellowish-brown, very fine grained to coarse-grained, locally granulitic, crossstratified, thin-bedded, micaceous, arkosic; interbedded with medium-greenish-gray micaceous and locally carbonaceous clayey siltstone; not as hard as underlying unit; forms slopes and ledges.

8. Sandstone, light-olive- to greenish-olivegray and pale-yellowish-brown, very fine grained to coarse-grained, micaceous, arkosic, thin- to thick-bedded, well-indurated, cross-stratified; some carbonaceous debris scattered through unit; locally conglomeratic and contains Precambrian and volcanic rock fragments as much as $1 \mathrm{ft}$ in diameter; amphiboles, pyroxene, and magnetite mark cross-stratification planes; cross-strata are low angle, lenticular, and small to medium scale; intercalated with light-olive- to dark-olive-gray mudstones; forms slopes and ledges........ 
Section of the Middle Park Formation along Colorado State Highway 125 northwest from Gold Run-Continued

Middle Park Formation (upper part)-Continued

7. Sandstone, partly covered, light-olive-gray, fine- to coarse-grained, micaceous, arkosic; amphiboles, pyroxene, and magnetite outline bedding planes; interbedded with conglomerate composed mainly of Precambrian crystalline rock; probably interbedded with soft olive-gray micaceous mudstones; forms slopes............

6. Sandstone, light-olive-gray, fine- to coarsegrained, thin- to thick-bedded, crossstratified, arkosic, micaceous, lenticularbedded; contains a few thin carbonaceous claystones as much as 6 in. thick; locally conglomeratic; forms massive ridges

5. Sandstone, partly covered, moderate-yellowish-brown, fine-grained to very coarse grained, arkosic, micaceous, thin-bedded, poorly bedded, cross-stratified, spheroidalweathering; bedding planes marked by hornblende, pyroxene, and magnetite; interbedded with dark-gray structureless micaceous siltstone; loadcasts near base of sandstone lenses; locally conglomeratic in upper part; contains lenticular beds of coarsegrained sandstone and a few thin (3-4 in.) impure coal beds or carbonaceous claystones; covered in upper part; forms slopes and ridges.

4. Sandstone, partly covered, light-olive-gray, fine- to coarse-grained, arkosic, crosslaminated, micaceous; laminations are marked by concentrations of amphibole, pyroxene, and magnetite; conglomeratic and contains pebbles as much as 2 in. in diameter; pebbles half Precambrian granitic and half andesitic volcanic; middle of unit poorly exposed but probably consists of soft micaceous siltstone and sandstones; intercalated with micaceous olive-drab clayey siltstones; forms ridges and slopes_.

3. Partly covered; mostly light-olive-gray and dusky-yellow structureless thin-bedded clayey siltstone; contains white mica; interbedded with micaceous very fine grained and fine-grained sandstone; volcanic conglomerate bed in middle of unit about $15 \mathrm{ft}$ thick; cobbles as much as $6 \mathrm{in}$. in diameter; some multicolored mudstones (including mustard, reddish brown, and greenish gray) near top of unit; forms slope

Thickness of Middle Park Formation (upper part) (rounded) 5,900
Section of the Middle Park Formation along Colorado State Highway 125 northwest from Gold Run-Continued

Middle Park Formation (upper part)-Continued Thickness Windy Gap Volcanic Member:

2. Breccia, volcanic, mostly greenish-gray, thick-bedded, massive; multilithologic breccia fragments are as much as $2 \mathrm{ft}$ in diameter and mainly porphyritic andesite; breccia mostly in upper part of unit; intercalated with volcanic siltstone, sandstone, and conglomerate; fractures coated with zeolites (analcime, stilbite, and heulandite); forms prominent ridge...............

Thickness of Middle Park Formation (rounded) _... 6, 600

Pierre Shale (part) :

1. Partly covered; mostly light-olive-gray clayey siltstone; forms slope beneath Windy Gap Member.

\section{TERTIARY ROCKS}

RABBIT EARS VOLCANICS

The Rabbit Ears Volcanics of Oligocene and Miocene(?) age (Izett, 1966) extends south from the crest of the Rabbit Ears Range into Middle Park and there covers uplands north of the Colorado River in the Hot Sulphur Springs quadrangle. The formation is well exposed on the east face of Elk Mountain, at Corral Peaks, around Slide Mountain, and near the west edge of the quadrangle north of East Fork Troublesome Creek. Some outcrops of the formation can easily be identified from a distance by their light color and rough surfaces. One of the more distinctive chalky-appearing outcrops occurs high on the northeast face of Elk Mountain, and it must have been a landmark for early settlers and travelers in Middle Park, for they named the mountain White Face (Marvine, 1874, p. 171). Regrettably, this descriptive name never appeared on later maps of the area. Because the formation contains large amounts of soft tuffaceous rock, landslides form in areas underlain by the formation, and the rocks are well exposed in some headwall scarps of these landslides. One of the larger landslides in the area is on the west side of Slide Mountain, and the formation is well exposed in the headwall scarp.

In the past the volcanic rocks were studied only in reconnaissance or mapped as part of thesis problems, and complete descriptions of the rocks have never been reported. Marvine (1874, p. 174) briefly mentioned these rocks, and Zirkel (1876) studied petrographic features of a few of the rocks. Later, Grout, Worcester, and Henderson (1913, p. 51) mapped in reconnaissance along the Rabbit Ears Range and described intrusive and extrusive rocks that included a breccia unit com- 
posed of "an immense deposit of fragments, with some flows"; they believed that the rocks were of late Eocene or younger age. Richards (1941) recognized the same sequence of volcanic rocks northeast of Kremmling, Colo., and assigned an Eocene age to the rocks. These rocks can be traced into the mass of breccia mapped by Grout, Worcester, and Henderson. Tollefson (1955), Tweto (1957), Shearer (1957), and Bombolakis (1958) briefly mentioned or mapped some of the volcanic rocks in Middle Park.

\section{THICKNESS}

The thickness of the formation changes markedly from south to north in the quadrangle. In southern outcrop areas the formation is generally thin $(0-100 \mathrm{ft})$ except where it fills topographic lows on the depositional surface. In the northern outcrop area at Elk Mountain and Corral Peaks, the formation may be as much as 800 feet thick, but abrupt changes in thickness over short horizontal distances are common. In secs. 3 and 4 , T. 2 N., R. 78 W., the formation is at least 800 feet thick, but less than 2 miles away in sec. $8, \mathrm{~T} .2 \mathrm{~N}$, R. $78 \mathrm{~W}$., it is less than 100 feet thick or is absent.

Along with thickness changes, marked differences in the lithic character of the formation occur from south to north. Most fragments along the southern outcrop margin are less than 2 feet in diameter, but to the north in the Elk Mountain-Corral Peaks area, blocks as much as 5 feet in diameter are fairly common. Large blocks also occur in the formation along East Fork Troublesome Creek. The increase in size of the fragments and the general thickening of the formation to the north indicate a northern source area for much of the volcanic detritus.

\section{LITHOLOGY}

In the quadrangle the formation consists chiefly of a complexly interlayered sequence of fragmental volcanic rocks and a few thin discontinuous trachyandesite and trachybasalt lava flows. Fragmental rocks compose the bulk of the formation and include breccia, tuff breccia, and tuff. The tuff is generally rhyolitic and comprises slightly welded and nonwelded varieties. Fragments in the tuff breccia and breccia vary widely in color and texture and range in composition from silicic to intermediate. Most fragments are porphyritic and contain phenocrysts of feldspar, biotite, hornblende, and pyroxene. The trachyandesite lava flows are interlayered with fragmental rocks in the upper part, and the trachybasalt lavas have been found only at the base of the Rabbit Ears. The trachybasalt lavas are a distinctive unit in the Rabbit Ears, and this unit was named the Pete Gulch Member by Izett (1966). Because of abrupt lithologic changes, subdivision of the formation is difficult, but some of the more con- tinuous and distinctive units were mapped and are described on the following pages.

\section{PETE GJLCH MEMBER AND RELATED DIZE}

Distinctive trachybasalt lava flows at the base of the Rabbit Ears Volcanics form the Pete Gulch Member (Izett, 1966). The member was named for good exposures north of Pete Gulch in secs. 4 and 9, T. 2 N., R. $79 \mathrm{~W}$, at the west edge of the quadrangle. The lavas are discontinuous and range in thickness from 0 to about 200 feet. Other outcrops of the Pete Gulch are at Corral Peaks, along the ridge that connects Corral Peaks with Elk Mountain, and north of East Fork Troublesome Creek at the west edge of the area.

North of Pete Gulch, at Slide Mountain, the member can be roughly divided into two parts. The lower part consists of about 70 feet of columnar jointed lava and is overlain by the upper part consisting of about 100 feet of massive blocky lava that weathers to ragged slopes littered with blocks about 1 foot on a side. This twofold division of the member suggests that the lower part chilled quickly and that cooling joints formed, whereas the upper part cooled more slowly and cooling joints did not form. Elsewhere in the quadrangle the member is made up of one flow unit that is massive and lacks well-formed cooling joints.

The Pete Gulch Member is the lowest part of the Rabbit Ears and rests unconformably on the Middle Park Formation. The lower contact of the member is usually covered by talus, but it is exposed in sec. 33, T. 3 N., R. $78 \mathrm{~W}$, along the ridge that connects Elk Mountain with Corral Peaks. At that locality the contact is sharp, and red scoriaceous vesicular trachybasalt of the Pete Gulch overlies sandstone of the Middle Park. The contact of the Pete Gulch and overlying part of the Rabbit Ears Volcanics is locally marked by a concentration of pebbles of Precambrian granitic rock in the tuff breccia above the trachybasalt lavas. Precambrian bedrock is nowhere exposed in areas near the flows, and the pebbles in the tuff were probably derived from the reworking of conglomerates rich in pebbles of Precambrian granitic rocks in the Middle Park Formation.

The Pete Gulch is dated as Oligocene inasmuch as it overlies the Middle Park Formation and seems to be spatially related to the lower part of the Rabbit Ears, which is dated as Oligocene by potassium-argon methods.

Hand samples of the fresh trachybasalt are dark gray to black and fairly dense and contain a few large conspicuous phenocrysts of pyroxene as much as $1 \mathrm{~cm}$ on a side set in the aphanitic groundmass. In addition to the pyroxene phenocrysts, scattered flakes of biotite about 
$0.5 \mathrm{~mm}$ long and smaller flow-oriented feldspar laths occur in samples of the lava in the Elk MountainCorral Peaks area. Samples in the Slide Mountain area contain iron-oxide pseudomorphs after hornblende as much as $1 \mathrm{~cm}$ long. The large pyroxene phenocrysts, biotite flakes, and iron-oxide pseudomorphs after hornblende make the lavas a distinctive rock unit in the area and help to distinguish it from younger basaltic lava flows of the Grouse Mountain.

Thin sections of the rock show that the large pyroxene phenocrysts are a clinopyroxene with noticeable pleochroism in thick grains from pale gray green to dusty brown and strong inclined dispersion. Optical properties of the clinopyroxene, listed in table 7 , indicate that the mineral is ferroaugite. Smaller phenocrysts of mafic minerals are ferroaugite, olivine, and biotite which has thick opaque borders of iron oxide. Pseudomorphs after hornblende seen in hand samples consist of small grains of magnetite, clinopyroxene, and interstitial chlorophaeite and quartz(?). Some samples of the lava contain phenocrysts of zoned twinned plagioclase $\left(A n_{7_{5-15}}\right)$ as much as $8 \mathrm{~mm}$ long that have reaction rims. The groundmass is mainly flow-oriented plagioclase laths about $0.2 \mathrm{~mm}$ long, rods and granules of augite, needles of apatite, and iron oxides. Patches of material with low birefringence scattered through the groundmass are probably analcime and alkali feldspar. Alteration products are saponite pseudomorphs after olivine, chlorophaeite, and calcite. Chemical analyses of the lava are listed in table 8 , columns 1 and 2 . The lava is characterized by its appreciable content of $\mathrm{K}_{2} \mathrm{O}$ for a basaltic rock; it could be called a basaltic andesite, an andesitic basalt, or an alkalic basalt, but the more general name trachybasalt for the rock seems best.

A trachybasalt dike that is petrographically similur to the lavas of the Pete Gulch Member cuts the Middle Park Formation in sec. 5, T. 2 N., R. $78 \mathrm{~W}$., on the northern slopes of Elk Mountain. The dike, which is about 50 feet wide and about 1,400 feet long, was probably one of the feeders for the lava flows of the Pete Gulch. Hand samples of the dike rock are dark gray to black and contain conspicuous phenocrysts of pyroxene. Under the microscope thin sections of the rock are similar to sections of lavas of the Pete Gulch. The pyroxene phenocrysts are a clinopyroxene (ferroaugite), some of whose optical properties are listed in table 7. Other small mafic-mineral phenocrysts are olivine and augite. The groundmass consists of flow-oriented plagioclase $\left(\mathrm{An}^{35-45}\right)$ laths, augite, and iron oxides. Alteration products include calcite, saponite, and analcite(?). TUFF BRECCIA AND BRECCIA

At most places in the area the Rabbit Ears consists of tuff breccia that locally grades into discontinuous lenticular masses of multilithologic breccia. The tuff breccia is well exposed at Elk Mountain, Corral Peaks, and Slide Mountain. Figure 11 shows a typical exposure of the tuff breccia at Corral Peaks. The tuff breccia commonly has a light- to medium-gray matrix composed of broken crystals of feldspar; mafic minerals including biotite, hornblende, and pyroxene; and small volcanicrock fragments. The breccia fragments range in size from microscopic to blocks as much as 5 feet in diameter. The breccia fragments are dominantly shades of gray, red, and brown, but some are black glassy fragments. The breccia fragments are generally porphyritic, range in composition from silic to intermediate, and include rhyolite, quartz latite, rhyodacite, and trachyandesite. Many of the fragments contain large phenocrysts of feldspar and smaller phenocrysts of biotite, hornblende, and pyroxene. Chemical analyses of a few of the more common breccia fragment types are listed in table 8.

A tongue-shaped mass of monolithologic porphyritic rhyolite breccia and minor associated conglomerate makes up the entire Rabbit Ears Volcanics between Jensen and Corral Creeks in the NW/4 sec. 6, T. $1 \mathrm{~N}$., R. $78 \mathrm{~W}$. Although the breccia is not widespread, it is a distinctive rock type and is shown on the map (pl. 1). The breccia extends west from under basalt flows (Grouse Mountain Basalt) to Corral Creek and rests on a moderately rugged terrain cut on granite of Precambrian age. Above Corral Creek at the tip of the tongue of rhyolite breccia, the rock unit is well indurated and is as much as 50 feet thick. The breccia is poorly sorted and shows no evidence of stratification. The fragments in the breccia are as large as 1 foot in diameter, and they weather to rough light-brown sur-

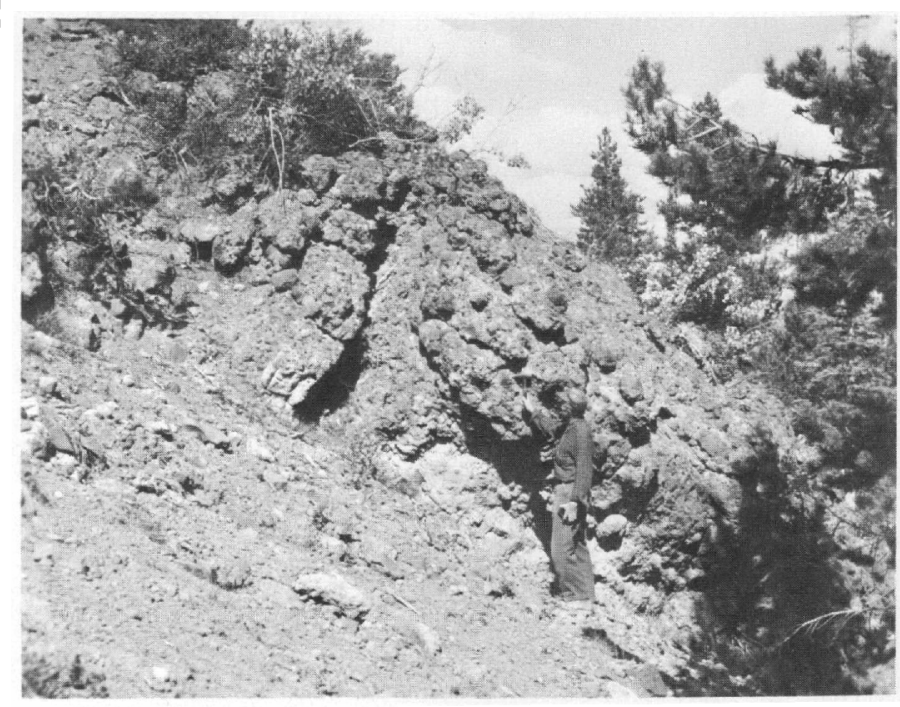

Figure 11.-Tuff breccia in the Rabbit Ears Volcanics at Corral Peaks. 


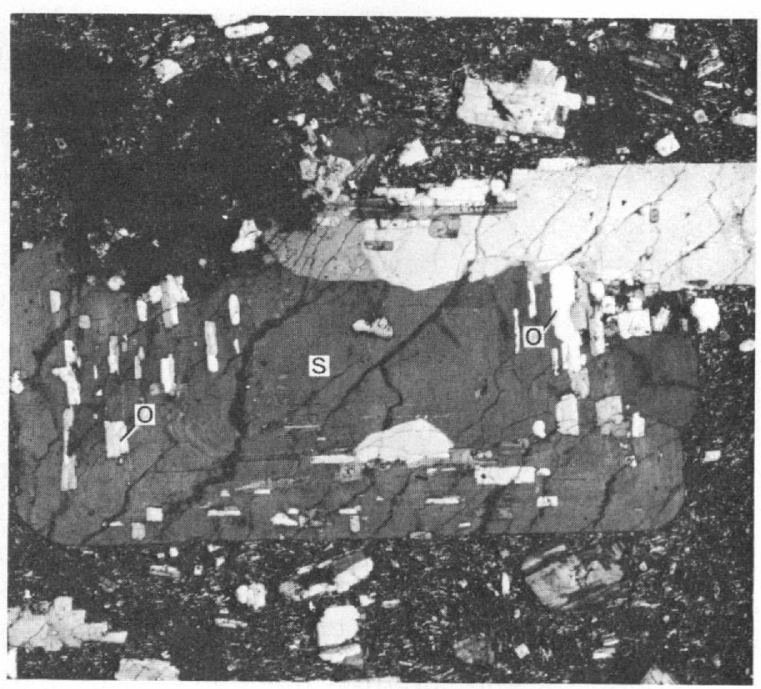

A

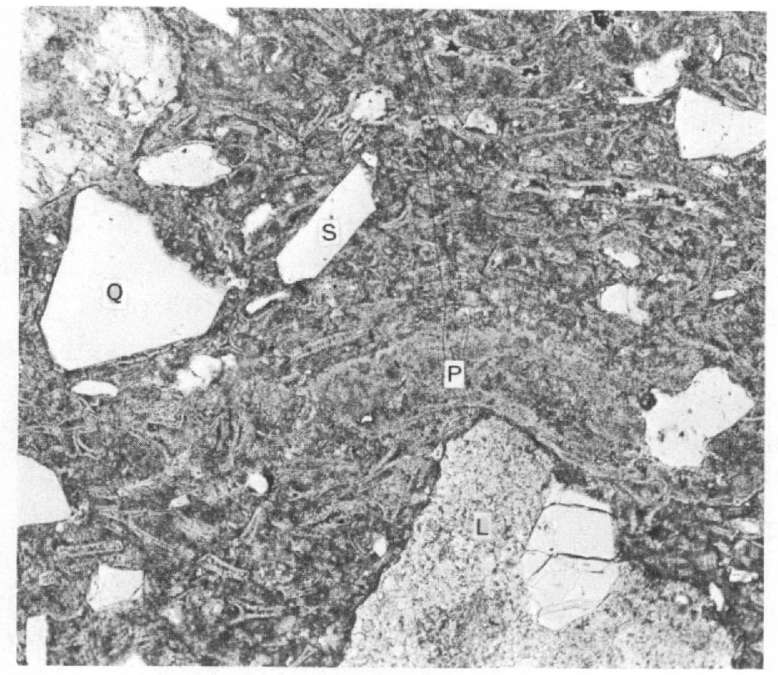

C

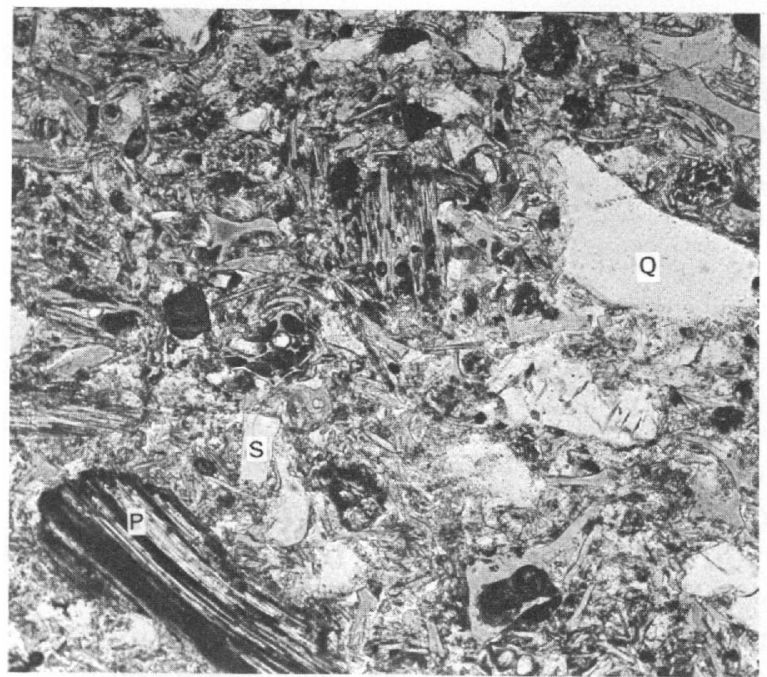

$B$

FIGURE 12.-Details of rocks in Rabbit Ears Volcanics. $A$, Oriented oligoclase inclusions in sanidine in porphyritic rhyolite; $\times 12$, crossed polars. $B$, Nonwelded quartz rhyolite ash flow tuff; shards are glassy and show no compaction; $\times 36$, plain light. C, Quartz rhyolite welded tuff showing slight welding by draped pumice fragment over a lithic fragment; $\times 36$, plain light. $L$, lithic fragment; $O$, oligoclase; $Q$, quartz; $S$, sanidine; $P$, plagioclase.

faces. The breccia could have formed by debris flow, but healed fractures, shattered fragments that retain their general shape, and open fractures filled with breccia matrix indicate that it was emplaced while hot and semiplastic and formed as a viscous flow breccia.

Breccia of this type is restricted to the southern part of the Rabbit Ears outcrop belt. The source of the rhyolite breccia is uncertain, but rhyolite porphyry intrusives at Porphyry Peaks in T. 4 N., R. 76 W., are petrographically similar and may have been the source of the breccia.

Megascopically, the rhyolite breccia fragments are light-gray to pink porphyritic rock containing conspicuous elongate feldspar crystals as much as $6 \mathrm{~mm}$ long set in an aphanitic groundmass. On close inspection, the feldspar crystals are seen to contain small zonally arranged lath-shaped inclusions.

Study under the microscope shows that the phenocrysts are chiefly euhedral zoned sanidine and plagio- clase and rare altered biotite and iron-oxide pseudomorphs after biotite and hornblende(?). Some optical properties of the feldspars are given in table 7 . The sanidine crystals characteristically contain inclusions of oscillatory-zoned oligoclase $\left(\mathrm{An}_{28-28}\right)$, some of which are oriented along growth zones in the sanidine. Figure $12 A$ is a photomicrograph of a sanidine crystal whose oligoclase inclusions are oriented so that the composition planes of albite and pericline twin lamellae in the oligoclase parallel the growth surfaces of the sanidine. Zoned twinned plagioclase phenocrysts are generally smaller than the sanidine phenocrysts and occur as single phenocrysts with resorbed borders or in clots intergrown with sanidine. The groundmass consists of felted microcrystalline aggregates of alkali feldspar and beta-cristobalite, alkali feldspar laths, and a little iron oxide. Estimates of the volume percent of the phenocrysts and groundmass are as follows: 
Plagioclase

Biotite ghosts

Hornblende ghosts

Groundmass:

Alkali feldspar
Cristobalite
Iron oxide.

77

A chemical analysis of the rhyolite is in table 8 , column 7 .

Irregular lens-shaped masses of monolithologic porphyritic quartz latite breccia are intercalated with tuff breccia, especially along Corral Creek in the $\mathrm{SW} / 4$ sec. 24 , T. 2 N., R. 79 W. Isolated fragments of porphyritic quartz latite identical with that which forms the breccia occur in mixed breccias and tuff breccia of the Rabbit Ears throughout the area, and they probably had a common source. The masses of breccia are generally too small and discontinuous to be mapped, but they are distinctive units that provide information on the source areas of the Rabbit Ears. The breccia weathers to gray craggy surfaces. Individual fragments of the breccia are as much as 1 foot in diameter and are well indurated. The quartz latite breccia shows features similar to the other silicic breccias in the area that seemingly were emplaced while hot and in a semiplastic state.
Hand samples of the rock are mottled medium gray and white. They have large feldspar phenocrysts as much as $15 \mathrm{~mm}$ long and small crystals of hornblende and pyroxene about $1 \mathrm{~mm}$ long set in an aphanitic groundmass.

Study under the microscope shows that the feldspar phenocrysts are chiefly plagioclase and subordinate euhedral zoned sanidine whose optical properties are shown in table 7. A few of the sanidine phenocrysts contain oriented twinned oligoclase $\left(\mathrm{An}_{25-29}\right)$ inclusions. Optical and X-ray properties of the sanidine imply that it has about 45 percent orthoclase molecule. The zoned twinned plagioclase phenocrysts are about $3 \mathrm{~mm}$ long and some show resorbed borders, alkali feldspar jackets, and dust and glass inclusions that form an incipient honeycomb structure. Mafic phenocrysts are euhedral zoned clinopyroxene whose optical properties (table 7) indicate that it is salitic augite. Iron-oxide pseudomorphs after biotite and biotite with opaque rims are common. Traces of euhedral sphene, apatite, zircon, and iron oxides are scattered through a felty to flow-oriented groundmass of plagioclase laths, alkali feldspar, and clinopyroxene rods. A distinctive petrographic feature of the rock is oriented oligoclase inclusions in sanidine, which help to separate the quartz latite breccia from other breccias in the Rabbit Ears.

TABLE 7.-Some optical properties of Tertiary volcanic rocks

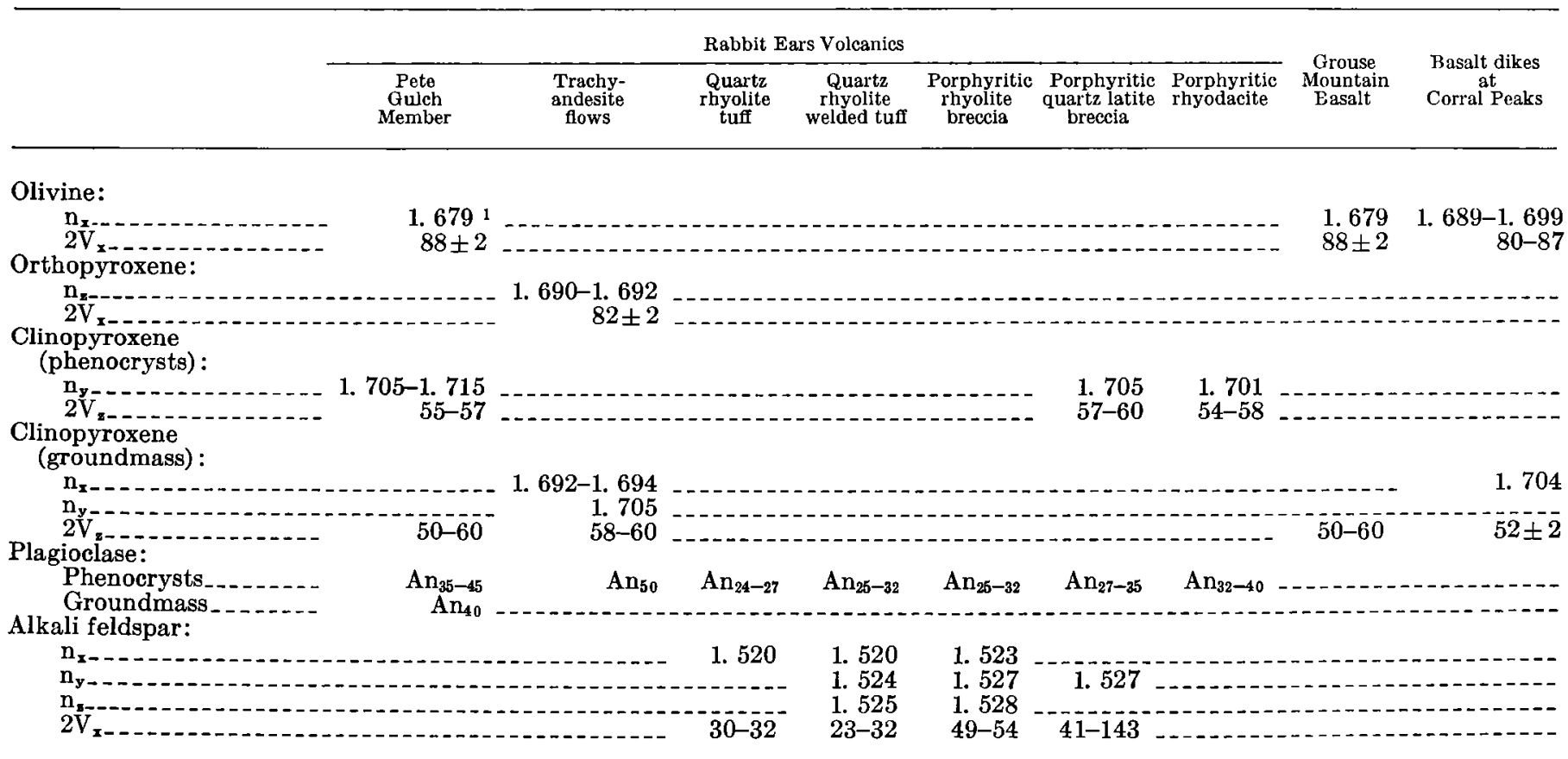

1 Index and optic angle determinations made on spindle stage and universal stage. Index determinations \pm 0.001. 
Results of a chemical analysis and computed normative minerals of the porphyritic quartz latite are listed in table 8, column 8. A mode of the rock is as follows:

\begin{tabular}{|c|c|}
\hline [Tr., trace] & Percent \\
\hline Matrix & 68 \\
\hline Sanidine_. & 4 \\
\hline Plagioclase_....... & 22 \\
\hline Augite (salitic) _. & 2 \\
\hline Mafic ghosts (hornblende and biotite) & 2 \\
\hline Hornblende & $<1$ \\
\hline Sphene & Tr. \\
\hline Apatite $_{1}$ & Tr. \\
\hline Zircon & Tr. \\
\hline - - - - & Tr. \\
\hline
\end{tabular}

The fragments that make up the breccia are petrographically similar to samples of porphyritic quartz monzonite silicic dikes at Willow Creek Pass and identical with samples of a small stock at Haystack Mountain in the Rabbit Ears Range. The breccia fragments probably had their source in these or similar intrusive rocks along the Rabbit Ears Range.

TUFF

Nonwelded quartz rhyolite ash flow tuff forms a distinctive mappable unit of the Rabbit Ears Volcanics and underlies a small area above Musgrave Ditch at the west edge of the quadrangle. The tuff rests with angular unconformity on an uneven southwest-dipping erosion surface cut on the Middle Park Formation. The tuff makes up the whole of the Rabbit Ears in the Musgrave Ditch area, and its stratigraphic position relative to thicker sections of the formation to the northwest is not accurately known, but tuffs similar to the quartz rhyolite tuff occur along East Fork Troublesome Creek in the upper part of the Rabbit Ears. The tuff in the mapped area is rarely well exposed, but it was seen in a few bulldozer cuts and is well exposed in the NW cor. sec. 27 , T. 2 N., R. 79 W. There, the tuff is as much as 90 feet thick and is a tumultuous poorly sorted frothy mass of glassy lumps of pumice as much as 1 foot in diameter set in a glassy low-density pumiceous matrix. The tuff contains dark-gray lithic fragments, is poorly stratified, and weathers to tepeeshaped forms. These characteristics imply that the tuff was deposited as part of an ash flow, whose source was probably to the north or northeast.

In hand sample the tuff is a light-gray punky rock containing scattered crystals of quartz, feldspar, and biotite, in decreasing order of abundance. Lithic fragments of volcanic rocks as much as 1 inch in diameter are scattered in the rock. Study under the microscope indicates that the rock is not welded, for it lacks compaction features. The tuff is mainly light-brown glass shards, the edges of which are only slightly devitrified, and lumps of glassy pumice. Fresh broken edges of the shards have a mean index of refraction of about 1.498 , which implies that the glass is rhyolitic. Phenocrysts in the tuff are poorly formed quartz dipyramids, sanidine, oligoclase, and biotite. Some optical properties of the feldspars are given in table 7 , and a photomicrograph of the tuff that shows its pyroclastic character is shown in figure $12 B$.

Thin discontinuous lenses of quartz rhyolite welded tuff and of monolithologic breccia whose fragments are quartz rhyolite welded tuff form conspicuous units in the Rabbit Ears. Although the quartz rhyolite is lithically unique in the area and may prove to be a regional time-stratigraphic marker in North and Middle Parks, the rhyolite was not mapped owing to poor exposure and lenticularity.

The quartz rhyolite is easy to recognize and is fairly widespread in the quadrangle. In southern outcrop areas, from the microwave relay station in sec. 5, T. 1 N., R. 78 W., to Smith Creek, the white-weathering quartz rhyolite forms scattered outcrops below the dark-gray- to black-weathering Grouse Mountain Basalt. The quartz rhyolite lenses are probably less than 20 feet thick in most areas and are intimately interlayered with other lenses of breccia. In the south, where the Rabbit Ears is thin, the rhyolite seems to be near the top of the sequence. But to the north at Elk Mountain where the formation is thicker $(800 \mathrm{ft})$, the rhyolite is about 400 feet above the base.

The quartz rhyolite occurs in at least two forms. On the southeastern slopes of Elk Mountain and at East Fork Troublesome Creek it seems to be a thin lenticular slightly welded ash flow tuff. Slight welding of the quartz rhyolite is indicated by incipient planar structure formed in part by slightly compacted pumice lumps. The degree of welding seems to vary from outcrop to outcrop.

At the microwave relay station near Jensen Creek and in sec. 30 , T. 2 N., R. 78 W., the quartz rhyolite forms lenses of monolithologic breccia units that were possibly emplaced as avalanche deposits formed from hot welded ash flow tuffs. Close inspection of the rock reveals a clastic texture; differential weathering of the clastic fragments that have various degrees of welding and induration produces a rough surface. Sawed polished slabs of the breccia show that the fragments form a mosaic texture made clear by random orientation of incipient planar structures in individual fragments (fig. 13). A few of the shattered fragments that form the mosaic texture can be reoriented visually to form larger coherent fragments that must have existed at one time. A few fragments show partly healed fractures that are wider near the margins of the 


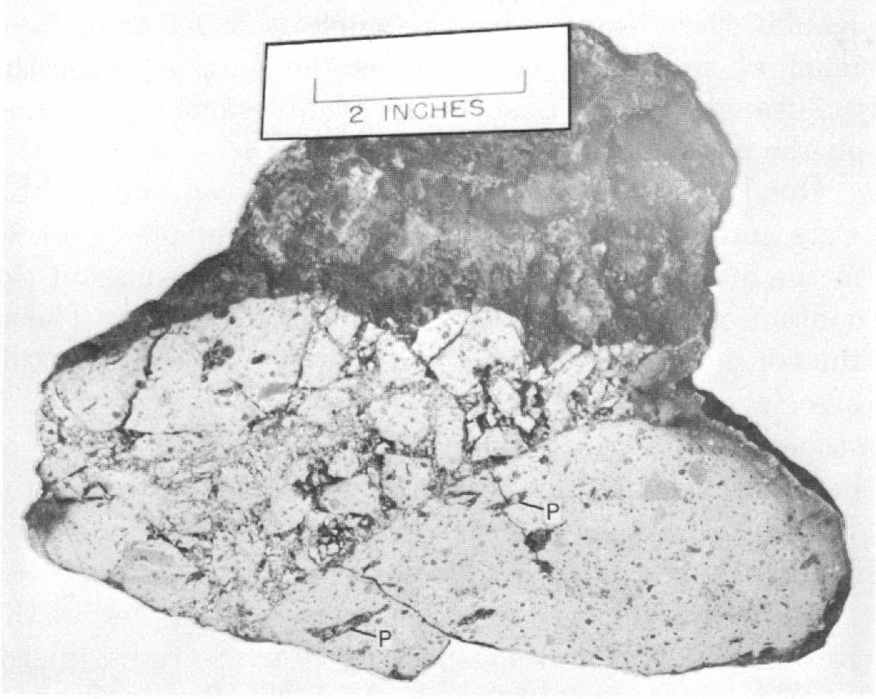

Figure 13.-Breccia composed of quartz rhyolite welded tuff in Rabbit Ears Volcanics. Slightly compacted pumice fragments are clearly shown in rhyolite. $\mathrm{P}$, pumice.

fragments, which probably indicates that the centers of the fragments were semiplastic at the time of emplacement but that the rims failed and fractured. The breccia resembles a tectonic breccia, but field relations contradict a tectonic origin.

In hand sample the quartz rhyolite is light gray to pink. The rock is porphyritic and has a well-indurated aphanitic groundmass. The phenocrysts are vitreous feldspar, well-formed quartz dipyramids, and rare flakes of biotite. Accidental fragments of granitic and gneissic rocks of Precambrian age and lithic fragments of older volcanic rocks as much as 1 inch long are widely scattered through the rock. Flattened lumps of pumice $10-20 \mathrm{~mm}$ long are encrusted with vapor-phase minerals. The pumice and faint shard outlines in the groundmass indicate the pyroclastic origin of the rock.

Under the microscope the feldspar phenocrysts are seen to be sanidine and plagioclase; some optical properties of the feldspars are given in table 7 . The sanidine occurs as fairly equant subhedral embayed crystals about $3 \mathrm{~mm}$ long that rarely contain randomly oriented oligoclase inclusions. Some of the sanidine crystals are twinned on the carlsbad law; a few are twinned on the manebach law. X-ray powder diffractograms imply that the sanidine is homogeneous and monoclinic and contains about $80-90$ percent orthoclase molecule. Plagioclase feldspar individuals are as much as $9 \mathrm{~mm}$ long, and they are zoned, subhedral, and twinned on the albite, albite-pericline, and albitecarlsbad laws, Quartz phenocrysts are about $2 \mathrm{~mm}$

long, show dipyramidal terminations, and are usually embayed. Flakes of altered biotite are rare and from their appearance may be xenocrysts. Devitrified pumice fragments as long as $20 \mathrm{~mm}$ consist of alpha-cristobalite, tridymite(?), and alkali feldspar. The groundmass is slightly compacted welded shards that show axiolitic structure under crossed polars. A photomicrograph of the quartz rhyolite (fig. 12C) shows the welding of the shards and a few incipient compaction features. The groundmass is alpha-cristobalite and alkali feldspar. Accidental fragments of microcline picked up by the hot ash flow are not sanidinized, which implies that the temperature of the ash flow was below minimum temperature of sanidinization. Estimates of the volume percent phenocrysts of the quartz rhyolite are shown as follows, and a chemical analysis of the tuff is given in table 8 , column 6 .

Modal analysis of quartz rhyolite welded tuff

Quartz

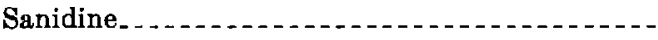

Plagioclase...............

Biotite . . . . .

Rock fragments.

Pumice fragments...........................

Groundmass (Alpha-cristobalite and alkali feldspar)

Quartz rhyolite tuffs that seem to be similar in gross aspect and age to the quartz rhyolite in the Hot Sulphur Springs quadrangle are apparently widely scattered in North and Middle Parks, but only a few descriptions of the rhyolites have been reported. Grout, Worcester, and Henderson (1913, p. 51) described a quartz rhyolite "south of Buffalo Mountain" that might be a welded tuff from North Park. The rock is "a pink porphyry in which quartz and vitreous oligoclase and orthoclase form phenocrysts in the pink groundmass. Under the microscope the groundmass proves to be glass." D. M. Kinney and W. J. Hail, Jr. (oral commun., 1964) reported quartz rhyolites from North Park that are similar to the quartz rhyolites in the Hot Sulphur Springs quadrangle. A sample of quartz rhyolite tuff that seems to underlie the intermontane basin-fill deposits of probable Miocene age near Hideaway Park in Middle Park, Colo., was collected by the writer from the $\mathrm{SE}_{1 / 4}$ sec. 28 , T. $1 \mathrm{~S}$., R. $75 \mathrm{~W}$. The potassium-argon age of sanidine separated from a quartz rhyolite tuff at Hideaway Park is $29 \pm 3$ m.y. (million years), which is about the same age as the potassium-argon date for quartz rhyolite from the Hot Sulphur Springs quadrangle (p. 36). The analytical data for the quartz rhyolite at Hideaway Park are as follows: 


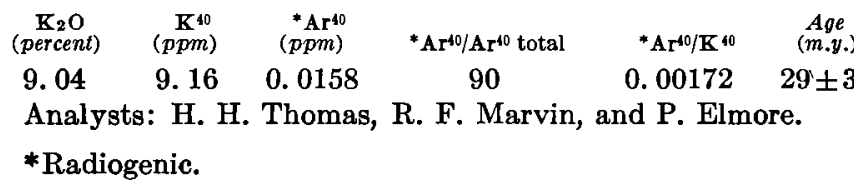

The source or sources for these rhyolites has yet to be found. The quartz rhyolites are petrographically related to rhyolitic welded tuffs such as at Specimen Mountain in Rocky Mountain National Park.

\section{TRACHYANDESITE}

Discontinuous trachyandesite lava flows are interlayered with fragmental rocks of the Rabbit Ears at Corral Peaks and at the west edge of the quadrangle north of East Fork Troublesome Creek. The flows are nowhere thicker than about 100 feet and can be traced only for short distances along the outcrop.

Hand samples of the lavas are light gray or brownish gray and some varieties contain small phenocrysts of feldspar, biotite, hornblende, and pyroxene. Study under the microscope shows that the feldspar phenocrysts are oscillatory-zoned andesine about $3 \mathrm{~mm}$ long, some of which are probably xenocrysts because they show reaction rims and a honeycomb structure. Maficmineral phenocrysts are about $0.5 \mathrm{~mm}$ long, and they include yellowish-brown biotite, reddish-brown hornblende, pargasite, salitic augite, and rare hypersthene. Pargasite (optically positive hornblende) crystals occur in druses and in the groundmass of the lava, and inasmuch as pargasite usually occurs in metamorphosed limestones, its occurrence is noteworthy. The optical properties of the pargasite are: $n_{x}=1.633-1.637$, pale brownish yellow; $\mathrm{n}_{\mathrm{y}}=1.644-1.648$, medium brown; $\mathrm{n}_{\mathrm{z}}=1.650-1.655$, olive drab $; 2 \mathrm{~V}_{\mathrm{z}}=68-72 ; Z \wedge C=19-21$; $r>v=$ moderate; distinct parting nearly parallel to (001). The optical properties of other minerals are listed in table 7 . The augite phenocrysts are relatively fresh, but the hydrous mafic minerals biotite and hornblende, which are commonly unstable in oxidizing conditions in many lava flows, show effects of roasting and have thick opaque iron-oxide rims. In some samples all that is left of the biotite and hornblende are iron-oxide pseudomorphs. The hypersthene phenocrysts must also have been unstable, for they show thick borders of bastite(?). The groundmass of the lava consists of felted plagioclase feldspar, oxidized microlites of a mafic mineral (amphibole?), and a few scattered crystals of roasted apatite that show faint pseudopleochroism. Chemical analyses of the lavas are given in table 8 , columns $3-5$.

CONTACT RELATIONS

In most areas in the quadrangle the formation rests unconformably on a rugged erosion surface probably cut during late Eocene and early Oligocene time on the Middle Park Formation. This erosion surface in the quadrangle had considerable relief at the beginning of Rabbit Ears time; it has as much as 500 feet of local relief at several places such as the west edge of the quadrangle above East Fork Troublesome Creek and on the east slopes of Corral Peaks.

Good exposures of the contact between the Rabbit Ears and the Middle Park can be seen at many places in the quadrangle, and especially good exposures of the contact occur on the east face of Elk Mountain. There, the contact is sharp and conspicuous and separates tuff breccia of the Rabbit Ears from conglomeratic sandstones of the Middle Park. In a few areas, such as between Corral and Jensen Creeks, a tongue of the Rabbit Ears laps onto Mesozoic sedimentary rocks and covers the trace of the Corral Creek thrust fault.

Along the southern margins of the outcrop belt of the Rabbit Ears Volcanics, especially near the radio microwave relay station in sec. 5, T. 1 N., R. 78 W., tuff breccia and breccia intergrade and are interlayered with claystones and conglomerates composed mainly of rounded fragments of granitic rocks of Precambrian age and a few fragments of Middle Park Formation and silicified wood. Slightly polished well-rounded pebbles of graphic granite are a characteristic type of pebble in the conglomerate. These claystones and conglomerates are similar to parts of the Troublesome Formation and may indicate that locally the Rabbit Ears Volcanics and the Troublesome interfinger. The rock fragments in the breccia are mostly subangular porphyritic light-gray rhyolite, medium-gray and red latite, and rhyodacite set in tuff matrices composed of broken feldspar and mafic minerals. Small lenses of monolithologic breccia that are well indurated and more resistant than the surrounding rocks form small knobs that resemble breccia plugs. That the lenses of breccia are not plugs is shown by the fact that the lenses can be traced laterally along the outcrop belt into other masses of breccia that are stratigraphic units in the Rabbit Ears. The fragments in the monolithologic breccia that form the knobs are less than 1 foot in diameter and consist of brownish-gray-weathering aphanitic vesicular rock that is probably rhyolitic.

\section{AGE}

The formation is roughly dated as Oligocene and Miocene(?) by its stratigraphic position above the Middle Park Formation of Late Cretaceous(?) and Paleocene age and below the Troublesome Formation of Miocene age. Corroborating the stratigraphic evidence of a Tertiary age for the Rabbit Ears is a potassiumargon age of $33 \pm 3 \mathrm{~m} . y$., or Oligocene, determined for sanidine from a rhyolite welded tuff breccia fragment collected by the writer from the formation in the center of sec. 23, T. 2 N., R. 79 W., in the Hot Sulphur Springs 
quadrangle. G. C. Curtin of the U.S. Geological Survey separated the sanidine from the tuff, and the sample was analyzed for potassium and argon by H.H. Thomas, R. F. Marvin, and Paul Elmore of the U.S. Geological Survey. The analytical data from the sanidine separate of the sample of welded tuff are given as follows:

\begin{tabular}{|c|c|c|c|c|c|c|}
\hline $\begin{array}{c}\text { Sample } \\
\text { No. }\end{array}$ & $\begin{array}{l}\mathrm{K}_{2} \mathrm{O} \\
\text { (per- } \\
\text { cent) }\end{array}$ & $\underset{(p p m)}{\mathbf{K}^{40}}$ & $\begin{array}{l}{ }^{*} \mathbf{A} \mathbf{R}^{10} \\
(p p m n)\end{array}$ & ${ }^{*} \mathrm{~A} \mathrm{R}^{40 / \mathrm{AR}^{40} \text { total }}$ & ${ }^{*} \mathrm{Ar} \mathrm{r}^{40} / \mathrm{K}^{40}$ & $\underset{(m, y .)}{A p e}$ \\
\hline GO6762 & 8.97 & 9.09 & 0.0176 & 91 & 0.00194 & $33 \pm 3$ \\
\hline
\end{tabular}

Decay constants: $\mathrm{K}^{40} \lambda \epsilon=0.585 \times 10^{-10} \mathrm{yr}^{-1}$. $\lambda \beta=4.72 \times 10^{-10} \mathrm{yr}^{-1}$.

Abundance: $\mathrm{K}^{40}=1.22 \times 10^{-1} \mathrm{~g} / \mathrm{g} \mathrm{K}$.

* Radiogenic.

The isotope age is probably a maximum age for the formation for two reasons: (1) the sample was a breccia fragment, and an unknown amount of time elapsed between the extrusion of the ash flow and the time it wrs fragmented and incorporated in the breccia; (2) the rhyolite contains rare xenocrysts of microcline that probably were derived from a rock of Precambrian age; the microcline might have contaminated the sanidine separated from the tuff and would tend to increase the age of the welded ash flow tuff if the microcline were not degassed during emplacement of the ash flow tuff. Locally, the Rabbit Ears is overlain by the Troublesome Formation of Miocene age in seemingly gradational contact, and an early Miocene age for part of the Rabbit Ears cannot be discounted. Accordingly, the formation is tentatively dated as late Oligocene and early Miocene(?).

\section{PETROCHEMISTRY}

Chemical and spectrographic analyses of the lavas and of a few of the more common breccia fragments in the Rabbit Ears Volcanics along with computed normative minerals (C.I.P.W.) are listed in table 8, columns 1-12. Chemical relations among the rocks are shown graphically by use of a silica-variation diagram shown in figure 14. Not all the oxides in table 8 were used in the silica-variation diagram, for some $\left(\mathrm{P}_{2} \mathrm{O}_{5}, \mathrm{MnO}_{2}\right.$, and $\mathrm{TiO}_{2}$ ) show little change with changing silica content. Some samples in table 8 were not used in the silicavariation diagram because they are markedly porphyritic or are, like sample 6 , an altered welded tuff that has an abnormally high content of silica. From the bulk analyses the major oxides of the rocks were recast volatile free, and these values were used for the diagram (fig. 14). Total iron is shown on the diagram as $\mathrm{FeO}$. The diagram shows that the curves for lime, magnesium, and iron descend with increasing silica content. The curve for aluminum rises gradually to a maximum near 61 percent silica and then descends. The general shapes and trends of these curves are, in general, similar to those of other published curves for igneous rock series.
Most of the samples analyzed, and especially sample G7662, column 1, table 8, contain appreciable amounts of potassium and sodium oxide relative to calcium oxide and silica. A frequently used index to show this relation among the alkalies, lime, and silica of an igneous rock series is the alkali-lime index of Peacock (1931), which is defined to be the silica value at which the sum of the alkalies equals the lime $\left(\mathrm{K}_{2} \mathrm{O}+\mathrm{Na}_{2} \mathrm{O}=\right.$ $\mathrm{CaO}$ ). The rocks in the Rabbit Ears have an alkalilime index of near 53 (fig. 14) and lie in Peacock's alkali-calcic clan near the alkali-calcic and calc-alkalic

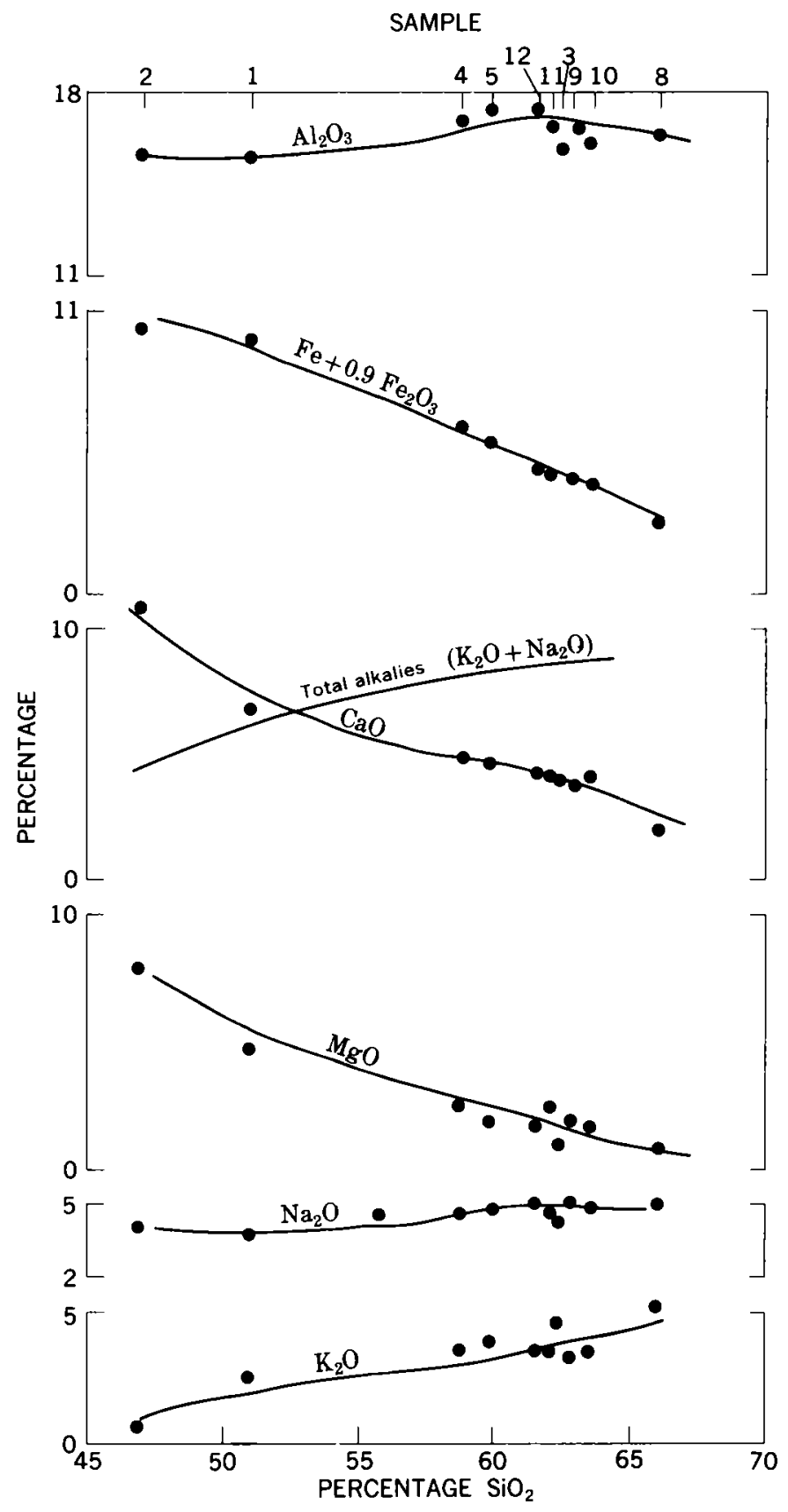

Figdre 14.- Silica-variation diagram of selected samples of Tertiary volcanic rocks. 
TABLE 8. - Chemical analyses and computed normative minerals of lavas and breccia fragments of middle and upper Tertiary volcanic rocks

[Chemical analyses, in percent, by rapid rock method (Shapiro and Brannock, 1962); analysts, P. Elmore, S. Botts, G. Chloe, L. Artis, and H. Smith. Semiquantitative spectrographic analyses, in percent, given to the nearest number in the series $1,0.7,0.5,0.3,0.2,0.15,0.1$, etc., which represents approximate midpoints of interval data on a peometric scall; the assigned interval for semiquantitative results will include the quantita-

\begin{tabular}{|c|c|c|c|c|c|c|c|c|c|c|c|c|c|c|c|c|c|c|c|}
\hline 1 & 2 & 3 & 4 & 5 & 6 & 7 & 8 & 9 & 10 & 11 & 12 & 13 & 14 & 15 & 16 & 17 & 18 & 19 & 20 \\
\hline
\end{tabular}

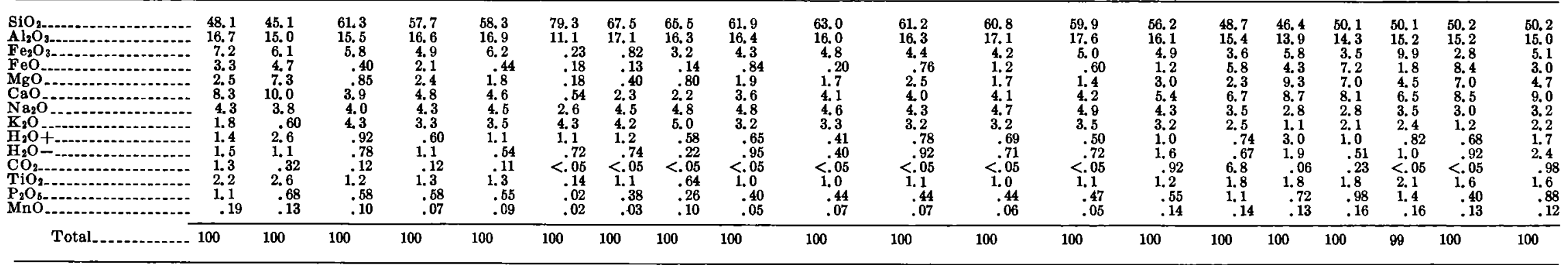

Powder density .......... 2.84

$2.51 \quad 2.55 \quad 2.62$

$\begin{array}{lllllll}2.79 & 2.86 & 2.94 & 2.89 & \ldots \ldots\end{array}$

Minor elements, in weight percent

\begin{tabular}{|c|c|c|c|c|c|c|c|c|c|c|c|c|}
\hline 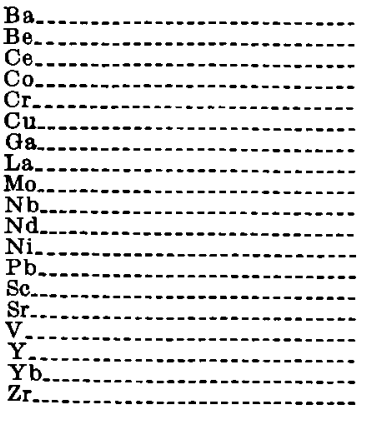 & $\begin{array}{l}0.2 \\
.0001 \\
.05 \\
.005 \\
.02 \\
.015 \\
.002 \\
.01 \\
.0003 \\
.002 \\
.02 \\
.01 \\
.0003 \\
.003 \\
.2 \\
.03 \\
.005 \\
.0005 \\
.02\end{array}$ & $\begin{array}{l}0.2 \\
.0001 \\
.02 \\
.002 \\
.002 \\
.003 \\
0.0015 \\
.015 \\
.007 \\
.003 \\
0.003 \\
<.003 \\
.002 \\
.001 \\
.15 \\
.01 \\
.003 \\
.0003 \\
.03\end{array}$ & $\begin{array}{l}0.2 \\
.0001 \\
.02 \\
.003 \\
.007 \\
.003 \\
0.015 \\
.0007 \\
.003 \\
0.015 \\
.002 \\
.001 \\
.01 \\
.015 \\
.003 \\
.0003 \\
.03\end{array}$ & $\begin{array}{l}0.2 \\
.0001 \\
.02 \\
.002 \\
.007 \\
.003 \\
.015 \\
.007 \\
.003 \\
0^{.01} \\
.002 \\
.001 \\
.001 \\
.01 \\
.003 \\
.0003 \\
.03\end{array}$ & $\begin{array}{l}0 \\
0\end{array}$ & $\begin{array}{l}0.15 \\
.00015 \\
.03 \\
.0015 \\
.005 \\
.002 \\
.0015 \\
.01 \\
.0003 \\
.002 \\
0.003 \\
.001 \\
.0007 \\
.15 \\
.007 \\
.002 \\
.00015 \\
.02\end{array}$ & $\begin{array}{l}0.2 \\
.00015 \\
.02 \\
.002 \\
.005 \\
.002 \\
.002 \\
.01 \\
.0003 \\
.002 \\
.01 \\
.003 \\
.001 \\
.001 \\
.2 \\
.007 \\
.002 \\
.0002 \\
.02\end{array}$ & $\begin{array}{l}0.15 \\
.00015 \\
.03 \\
.002 \\
.005 \\
.002 \\
.002 \\
.01 \\
.0003 \\
.002 \\
.01 \\
.003 \\
.001 \\
.0007 \\
.2 \\
.007 \\
.002 \\
.00015 \\
.02\end{array}$ & $\begin{array}{l}0.2 \\
.00015 \\
.02 \\
.0015 \\
.005 \\
.002 \\
.002 \\
.01 \\
.0003 \\
.002 \\
.01 \\
.003 \\
.0015 \\
.001 \\
.2 \\
.01 \\
.002 \\
.0002 \\
.02\end{array}$ & $\begin{array}{l}0.2 \\
.00015 \\
.05 \\
.0015 \\
.005 \\
.003 \\
.002 \\
.015 \\
.0003 \\
.003 \\
.015 \\
.003 \\
.0015 \\
.0007 \\
.2 \\
.007 \\
.002 \\
.0002 \\
.02\end{array}$ & $\begin{array}{l}0.2 \\
.0001 \\
.02 \\
.002 \\
.005\end{array}$ & $\begin{array}{l}0.05 \\
.0001 \\
0.005 \\
.03 \\
.005 \\
.002 \\
0.0003 \\
.001 \\
.015 \\
.0003 \\
.002 \\
.07 \\
.015 \\
.003 \\
.0003 \\
.015\end{array}$ \\
\hline
\end{tabular}


Normative minerals (C.I.P.W.)

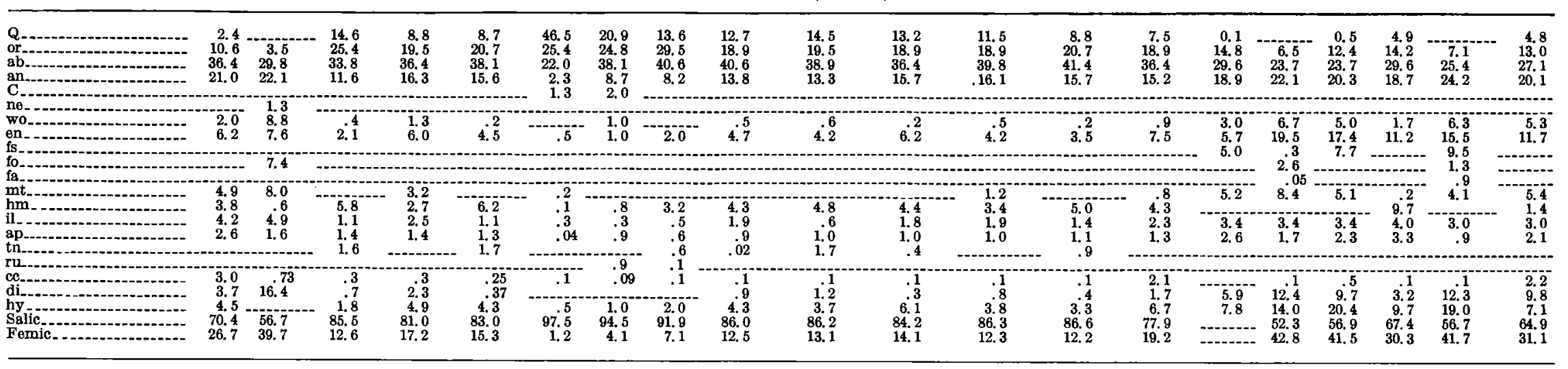

\section{SAMPLE LOCALITIES}

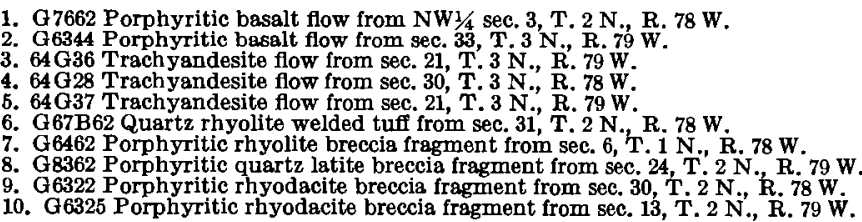

11. G6319 Porphyritic rhyodacite breccia fragment from sec. 30, T. 2 N., R. $78 \mathrm{~W}$.

12. G6327 Porphyritic rhyodacite breccia fragment from sec. 23, T. 2 N., R. 79 W.
14. G6342 Porphyritic trachyandesite breccia fragment from sec. 20 , T. 3 N., R. 78 W.
14. 64 G31 Trachyandesite plug from sec. 28 , T. 3 N., R. 78 W.

15. G4862 Basalt flow from sec. $36, T$, T. 2 N., R. $79 \mathrm{~W}$.

17. G5462 Basalt flow from sec. 22, T. 2 N., R. $79 \mathrm{~W}$

19. G6332 Basalt dike from sec. $20, T$, 3 N., R.78 W. 
boundary. The rocks lack the soda-rich amphiboles and pyroxenes that, according to Peacock, typify his alkali-calcic clan, and they locally contain traces of orthorhombic pyroxene that, according to Peacock, typify his calc-alkali series. A short list of alkali-lime index values including a value for those in the Rabbit Ears Range and certain other volcanic areas in western North America is given as follows.

\begin{tabular}{|c|c|c|}
\hline Aтеа & $\begin{array}{l}\text { Alkali-lime } \\
\text { index }\end{array}$ & Source \\
\hline Rabbit Ears Range, & Near 53.. & This report. \\
\hline $\begin{array}{l}\text { San Juan Mountains, } \\
\text { Colo. }\end{array}$ & Near 57 & $\begin{array}{l}\text { Larsen and Cross (1956, } \\
\text { p. } 80,87,167 \text {, and }\end{array}$ \\
\hline Colfax County, N. Mex & Near 53 & $\begin{array}{l}\text { Mertie }(1922, \text { p. 11); } \\
\text { Stobbe (1949, p. 1053, } \\
\text { 1067); C. L. Pillmore } \\
\text { (oral commun. 1965). }\end{array}$ \\
\hline Spanish Peaks, Colo_-_ & & Knopf $(1936$, p. 1780 \\
\hline $\begin{array}{l}\text { aricutin Volcano, } \\
\text { Mexico. }\end{array}$ & Near 62 & Wilcox (1954, p. 315). \\
\hline $\begin{array}{l}\text { Mount Lassen region, } \\
\text { Calif. }\end{array}$ & Near 64 & Williams (1942, p. 153). \\
\hline
\end{tabular}

Volcanic rocks in the Rabbit Ears are seemingly more alkalic than the middle and upper Tertiary volcanic rocks of the San Juan Mountains, Colo., and are considerably more alkalic than the volcanic rocks of Mount Lassen, Calif., and the volcanic rocks related to Paricutin volcano, Mexico. The Rabbit Ears Volcanics apparently has about the same alkali-lime index as the volcanic rocks of Colfax County, N. Mex., and is more calcic than the alkalic rocks at Spanish Peaks, Colo. Rocks of about the same age from five volcanic centers at the Nevada Test Site and vicinity, Nye County, Nev., have a wide range in alkali-lime index values ranging from about 50 to 68 (Noble and others, 1965; D.C. Noble, oral commun., 1965). These marked differences in alkali-lime index values from one area cast doubt as to the usefulness of alkali-lime index values to characterize certain petrographic provinces.

TRAChyandesite PLUG

A trachyandesite plug too small to be mapped cuts the lower part of the Rabbit Ears Volcanics along the ridge that connects Corral Peaks and Elk Mountain in the northern part of the area. Much of the trachyandesite is brecciated and shows sharp boundaries with the country rock. The country rock is well indurated next to the contact with the trachyandesite and forms a small ridge that outlines the plug. The trachyandesite plug is probably about the same age as the upper part of the Rabbit Ears Volcanics and was probably a source for breccia fragments in the Rabbit Ears.

Hand samples of the rock are mottled brownish gray and white. The rock contains small phenocrysts of feldspar, amphibole, and mica. Under the microscope the feldspar phenocrysts are seen to be twinned zoned andesine $\left(\mathrm{An}_{35-40}\right)$. The amphibole is reddishbrown hornblende that shows thick opaque borders and contains inclusions of pyroxene. Other phenocrysts of mafic minerals are salitic augite $\left(\mathrm{n}_{\mathrm{y}}=1.705 ; 2 \mathrm{~V}_{\mathrm{z}}=\right.$ 56-58) and biotite that shows thick opaque borders of iron oxides and reaction rinds. The groundmass consists of felty plagioclase, altered microlites of biotite and amphibole, and pyroxene microlites. Alteration products include calcite and zeolites (heulandite?). Small crystals of apatite are widely scattered.

A chemical analysis of the rock is listed in table 8, column 14. The analysis shows that the rock is saturated with respect to silica and contains a little less potassium oxide and a little more silica than the average of 42 latites (trachyandesite) compiled by Nockolds (1954, p. 1017, col. 2) and 10 latites compiled by Daly (1933, p. 13).

Tuffaceous sedimentary rocks of late early and late Miocene age that range in thickness from about 0 to 400 feet in the mapped area compose the Troublesome Formation, which underlies about 20 square miles of low grass- and sage-covered lands in the southwestern part of the quadrangle. The formation mantles the older rocks in the area and effectively conceals many of the premiddle Tertiary geologic relations. The formation in this area is typically poorly exposed, but a few good exposures occur in roadcuts, in gullies, and in the headwall scarps of landslides. Complete exposed sections of the formation that could be used as reference sections for the mapped area are lacking, and stratigraphic relations must be inferred from isolated outcrops. A fairly complete well-exposed section, here designated a reference section of the Troublesome, occurs west of the mapped area in the $\mathrm{SW} / 4$ sec. 24, T. 1 N., R. 80 W., in Barger Gulch, Kremmling quadrangle (fig. 15). The section in Barger Gulch does not contain all lithic phases of the Troublesome, but it characterizes the bulk of the formation. A reference section of the Troublesome and another partial section of the formation are given at the end of the discussion of the Troublesome.

Upper Tertiary rocks in the Kremmling area were called "lake beds" by Marvine (1874, p. 157) and North Park Formation by Burbank, Lovering, Goddard, and Eckel (1935), who assigned a Miocene(?) age to the formation. Later, Lovering and Goddard (1950, p. 41) used the name Troublesome Formation, a name that had been applied by Richards (1941) to the poorly understood basin-fill sedimentary rocks near Kremmling, Colo.; they suggested that most of the rocks might be of Oligocene age and "locally [the formation] was reworked in Miocene and early Pliocene time." Lovering 


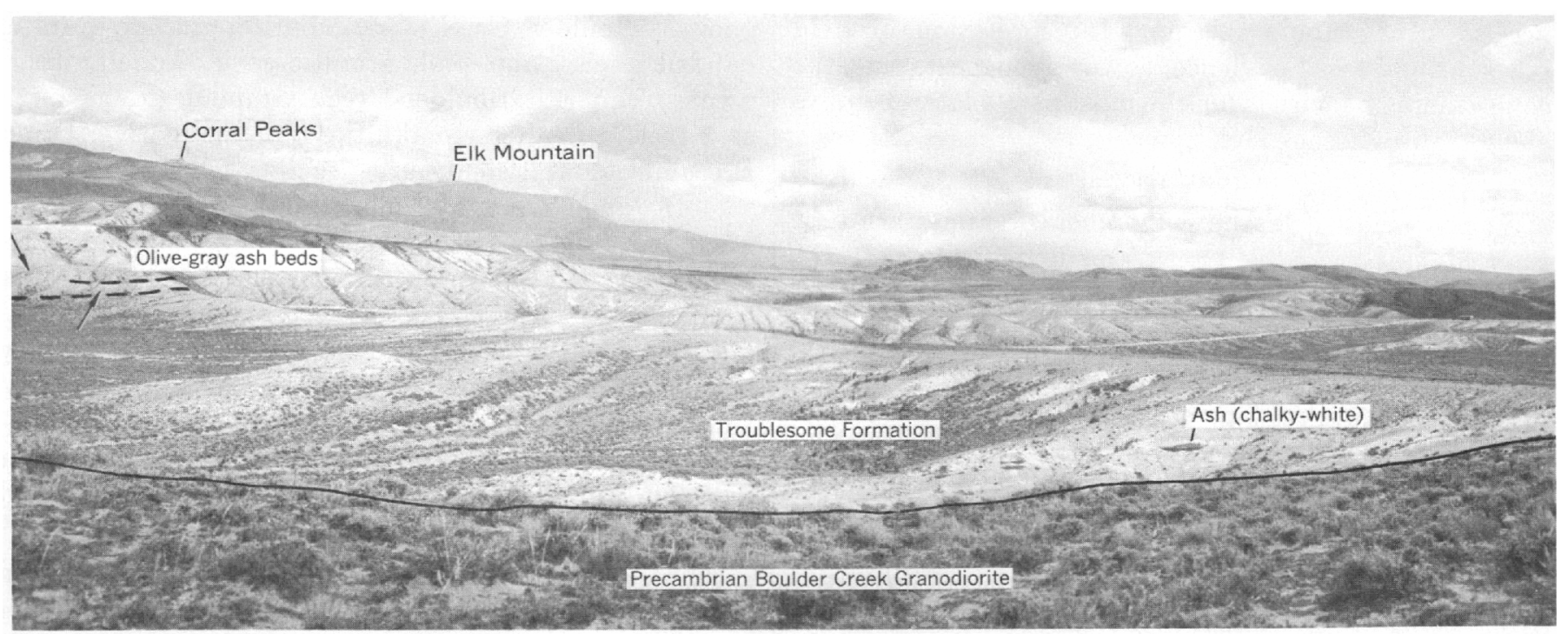

Figure 15.- Reference section of the Troublesome Formation in lower Barger Gulch, showing location of prominent ash beds in the SW/4 sec. 24, T. 1 N., R. 80 W., Kremmling quadrangle. Locations of fossil remains of Brachycrus and Merychippus are shown by arrows. Beds in foreground dip about $25^{\circ}-30^{\circ} \mathrm{NE}$.

(1930, p. 74) found mammalian fossils, dated by Cook as of Arikaree age, in the Troublesome Formation of the Granby anticline area. Present knowledge of the age of the Troublesome dates from 1962, when the writer found well-preserved diagnostic fossil mammals identified by Lewis as comparable to the fauna of the Hemingford Group of Lugn (1939). The name Troublesome Formation is used for the Miocene rocks in Middle Park, rather than other available names including North Park, Browns Park, Pawnee Creek (Matthew, 1901), or Arikaree used for Miocene rocks in surrounding areas, owing to faunal and lithic correlation problems that await regional solution and the possibility that the Miocene deposits of Middle Park were deposited in an intermontane basin, perhaps separated from other areas of Miocene rocks. Sedimentary petrographic studies of the Arikaree, Ogallala, and other Tertiary formations of the High Plains and Rocky Mountains, such as the one made by Sato and Denson (1967) should aid in the solution of correlation problems on a regional scale.

Estimates of the thickness of the Troublesome in the area are subject to considerable error because of the large amount of relief on the surface upon which the formation was deposited, but the following estimates give some idea of the range of the thicknesses. The formation is probably about $200-300$ feet thick north of the Colorado River and about 400 feet thick south of the Colorado River in sec. 14, T. 1 N., R. 79 W. The formation is probably no thicker than 400 feet in much of the area of the Williams Fork Reservoir. To the west in the Kremmling quadrangle the formation is at least 970 feet thick. Much of the formation in the area has been removed by erosion, and the original thickness is unknown; however, field relations indicate that it might have been as much as 1,500 feet thick.

The Troublesome constitutes a mappable lithogenetic unit composed of beds that locally show abrupt lithic changes that reflect local changes in source rocks. The rocks were deposited during Miocene time in a small basin formed in the older rocks that floor Middle Park. Based on the dominance of siltstone and conglomerate, the Troublesome can be divided into two parts whose areal distribution is shown on plate 1 . Only a scratch boundary is shown separating the two parts of the formation on plate 1 because locally their precise stratigraphic relation is not clear and their lithic separation is arbitrary.

One part of the formation, here called the siltstone facies, is characterized by orange-gray chert-bearing clayey siltstone that contains many thin beds of ash, including distinctive zones of white ash beds that occur near the base and the middle of the formation and zones of olive-gray ash that occur in the upper part of the formation. The siltstone facies forms the bulk of the formation and is exposed mainly sauth and east of Cedar Ridge.

The second part of the Troublesome, here called the conglomeratic facies, is characterized by varicolored conglomeratic swelling claystones that commonly contain silicified splintery fossil wood. It is exposed mainly north of the Colorado River. In all areas studied in the quadrangle, the Troublesome consists entirely of rocks included in either the conglomeratic facies or the siltstone facies-nowhere are the facies superposed in a vertical section that would definitely establish their 
SILTSTONE FACIES

The siltstone facies of the Troublesome Formation crops out east of Williams Fork Reservoir as far east as Little Muddy Creek and extends west from the reservoir into the Kremmling quadrangle. The unit is best exposed west of the quadrangle in Barger Gulch in the Kremmling quadrangle. The unit consists of orange-gray, gray, and greenish-gray earthy siltstone; orange gray is the most common color and seems to characterize the unit. The siltstone lacks fissility and is generally limy. Mechanical analyses of samples of rocks in the siltstone facies made by R. F. Gantnier of the U.S. Geological Survey showed that the rocks are silt ( 80 percent), very fine grained sand ( 15 percent), and clay ( 5 percent). At several places in the area the siltstone is interlayered with beds $2-3$ feet thick of rough-weathering earthy limestone locally rich in clay galls. The siltstone contains a few thin layers of white chert less than 2 feet thick that probably are altered ash beds. In areas where the siltstone facies is covered with soil the siltstone facies can be mapped by tracing float from these chert beds. Chert nodules as much as 3 inches in diameter that show rinds marked by dessication cracks are scattered on some outcrops of the unit. At some places in the area the siltstone contains small blobs of white to pink montmorillonite that probably are devitrified lumps of ash. Conglomerate that is made up of granules of dark-brown siltstone or granitic rocks forms a subordinate part of the siltstone facies. Heavy minerals separated from samples of the siltstone facies collected from the mapped area and from the Kremmling quadrangle are listed in table 10 and discussed in another section of the report.

\section{CONTACT RELATIONS}

The Troublesome rests with marked unconformity on older rocks of widely different ages. The unconformity at the base of the formation is well exposed in a roadcut along U.S. Highway 40 near the west edge of sec. 10 , T. 1 N., R. 79 W. There, the formation is conglomeratic and limy at its base and overlies the Niobrara Formation, which dips gently to the north. Traced north, the unconformity truncates another unconformity which separates the Pierre Shale and the Middle Park Formation. The amount of relief on the surface of unconformity in this area is perhaps 500 feet in half a mile. Just south of the quadrangle in sec. 3 , T. 1 S., R. $78 \mathrm{~W}$., the Troublesome rests with angular unconformity on the Middle Park Formation. In some areas such as in the central part of sec. 35, T. 2 N., R. 79 W., the unconformity at the base of the formation is marked by large amounts of conglomerate; yet in other areas such as in roadcuts in sec. 34 , T. 1 N., R. 79 W., silty orange claystones of the Troublesome rest sharply on Boulder Creek Granodiorite of Precambrian age. The
Troublesome is unconformably overlain by the Grouse Mountain Basalt in sec. 36, T. 2 N., R. 79 W., and by conglomerate and mudstone of Pliocene age in sec. 33 , T. 1 N., R. $79 \mathrm{~W}$.

IMODE OE DEPOSITION

In the past many of the middle and upper Tertiary sedimentary formations of the Western Interior, including the beds here assigned to the Troublesome Formation, were called lake beds in reference to their even and horizontal bedding. Matthew (1901) presented convincing stratigraphic and paleontological evidence that shows that many of these formations could not have been deposited in large fresh-water lakes. Among the evidence cited by Matthew are the following facts: The formations contain an exclusively terrestrial fauna (fig. 17) and lack fossil fish, and lamination in the rocks that is characteristic of lake deposits is lacking. Other evidence that might indicate that the Troublesome was not deposited in a lake includes the presence of structures interpreted to be channel-fill deposits, and the presence of root casts in growth positions. The Troublesome was probably deposited in a small intermontane basin by streams that were overloaded chiefly with pyroclastic material washed from the adjoining Rabbit Ears Range highlands after an episode of middle Tertiary volcanism. Recurrent volcanism, probably from distant sources, occurred during deposition of the Troublesome as indicated by many beds of air-fall ash. A few small ephemeral ponds must have been present locally on the floor of the basin, for the Troublesome contains a few beds of fresh-water limestones and fossil snails in the Kremmling quadrangle.

The Troublesome Formation was deposited along the margins and in the arms of a small intermontane basin, here named the Troublesome basin. This basin is one of several small basins that formed in Miocene time in Middle Park and were filled chiefly with tuffaceous sediments stripped from the adjoining highlands after a regional episode of middle Tertiary volcanism. Locally derived material including granitic and volcanic rock fragments were shed from the highlands and locally form major units in the Troublesome. The Troublesome basin is about 25 miles long, trends north, and lies mainly west of Troublesome Creek in the Kremmling quadrangle and extends south from near Gunsight Pass to south of the 40th parallel. Arms of the basin extend east from the Kremmling quadrangle into the Hot Sulphur Springs quadrangle. Generally the conglomeratic facies was deposited only along the east and west margins of the Troublesome basin, and the siltstone facies was deposited elsewhere in the basin.

\section{AGE AND CORRELATION}

A few well-preserved skeletal parts, jaws, and skulls of mammals useful for dating purposes were found in 


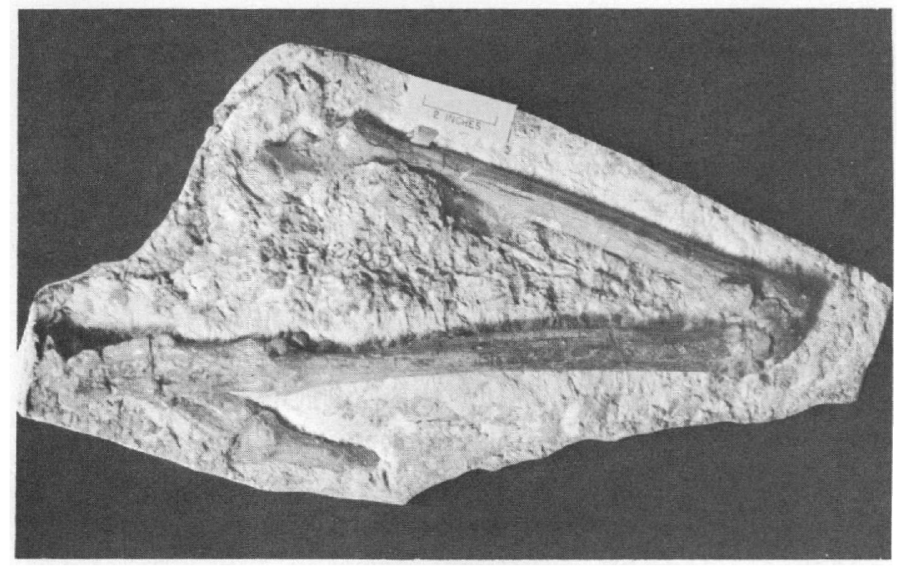

Figure 17.-Vertebrate fossils in the Troublesome Formation. Left, Articulated camel leg bones found by the writer in the Troublesome Formation in the NW1/4 sec. 30, T. 2 N., R. 79 W. Collected by G. E. Lewis, G. A. Izett, and R. W. O'Donnell of the U.S. Geological Survey. Below, Skull of the oreodont Merycochoerus found at roadeut in Troublesome Formation at west edge of quadrangle (fossil loc. 2, fig. 2).

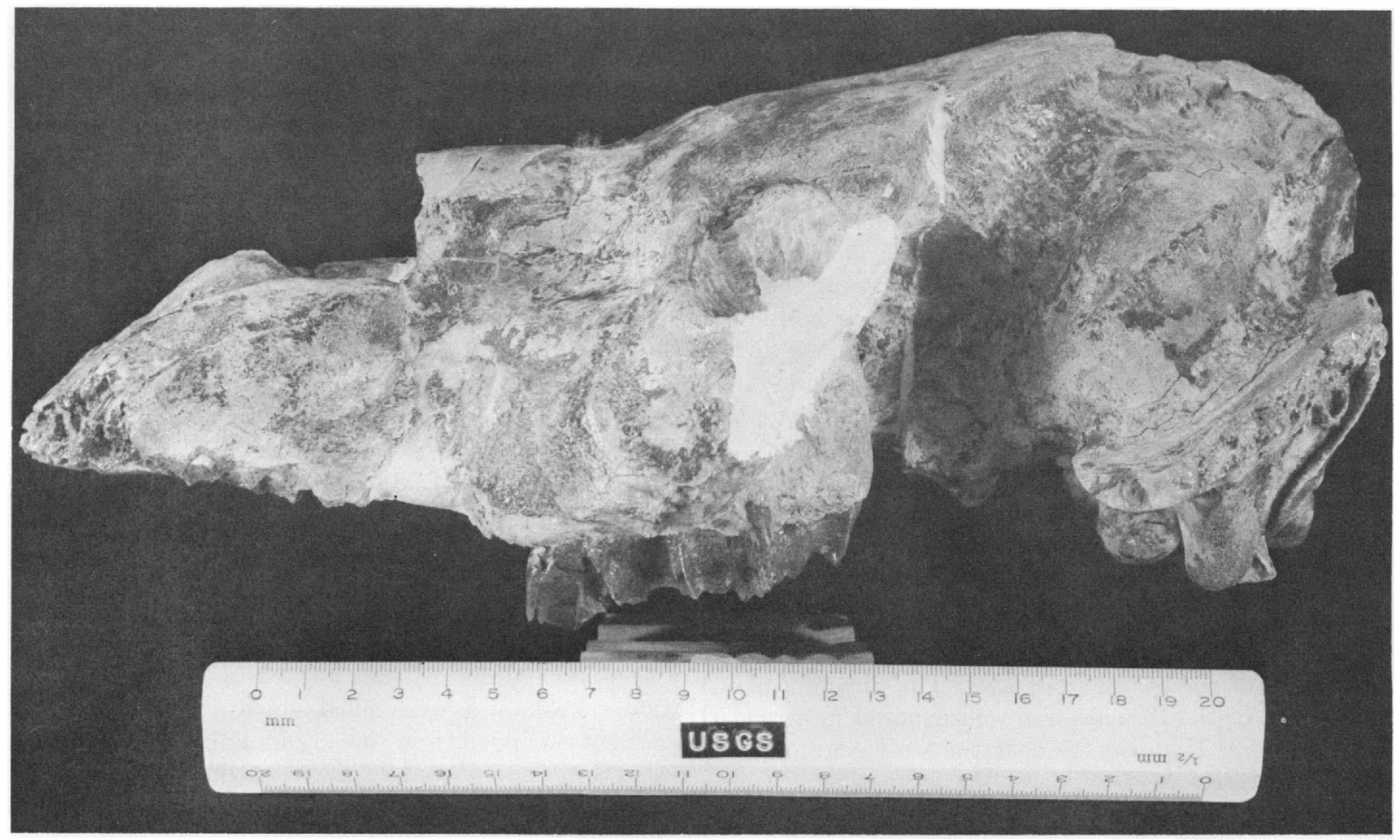

the mapped area on some of the bare slopes of the Troublesome; the fossil localities are shown on plate 1 . Fossils found in the Troublesome are listed in table 9. No fossils other than nondiagnostic bone scraps were found in the upper part of the formation in the mapped area, but many fossils, which are being studied by G. E. Lewis of the U.S. Geological Survey and Peter Robinson of the University of Colorado, were found in the upper part of the formation in the siltstone facies in the Kremmling quadrangle, and a preliminary list is given in table 9. Many of the fossil mammals found in the region occur in the thin volcanic ash beds, and these ash beds are good prospecting sites. Among the possibilities that could explain the relation between ash beds and fossil mammal remains are: Animal remains were quickly covered by ash and preserved; animals were killed directly by air-fall ash; and animals were starved because their food supply was covered.

Pollen and spores collected by the writer and Louise Weiler occur in siltstones and conglomerates in the Troublesome west of the mapped area, and they have been described by E. B. Leopold (in Weber, 1965, p. 
455-456). Fossil fresh-water clams and snails were collected by the writer in the upper part of the formation in the SW $1 / 4 \mathrm{SW} / 1 / 4$ sec. 6, T. 1 N., R. 79 W. D. W. Taylor of the U.S. Geological Survey (written commun., 1966) identified the fossils as the fresh-water clam Sphaerium and the fresh-water snails Lymnae (Stagnicola?) sp., Bulimnea? sp., and a small planispiral species.

TABLE 9.-Fossil vertebrates from the Troublesome Formation (Miocene)

[Identification by G. E. Lewis, U.S. Geol. Survey, except where noted. Locality numbers not arranged in stratigraphic order]

\begin{tabular}{|c|c|c|}
\hline $\begin{array}{l}\text { Locality } \\
\text { on } \\
\text { fig. } 2\end{array}$ & Lithology & Fossils \\
\hline & & Upper part \\
\hline \multirow[t]{2}{*}{ (I) } & $\begin{array}{l}\text { Orange-gray clayey silt- } \\
\text { stone. }\end{array}$ & $\begin{array}{l}\text { Merychippus aff. M. sejunctus. } \\
\text { Merychippus sp. } \\
\text { ?Anchitherium sp. } \\
\text { Aphelops profectus? } \\
\text { Protolabis angustidens } \\
\text { Aepycamelus sp. } \\
\text { Oxydactylus- or Protolabis-like camel. } \\
\text { Brachycrus sp. } \\
\text { Merycodont. } \\
\text { Mesogaulus laevis. } \\
\text { Monosaulax sp. }\end{array}$ \\
\hline & & Lower part \\
\hline 1 & Greenish-gray sandy & \multirow{9}{*}{ 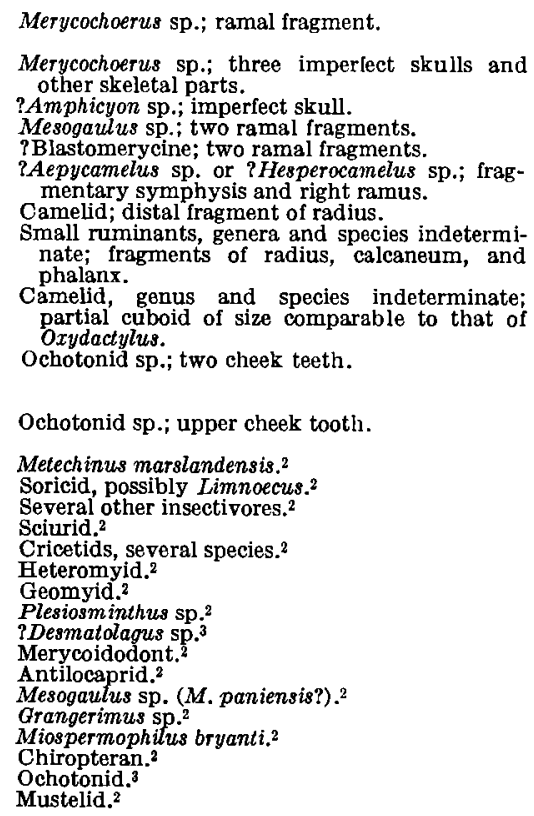 } \\
\hline 2 & $\begin{array}{l}\text { Reddish-brown siltstone } \\
\text { containing conglom- } \\
\text { eratic stringers. }\end{array}$ & \\
\hline 3 & - trave do do & \\
\hline 4 & $\begin{array}{l}\text { Gray sandy granulitic } \\
\text { claystone. }\end{array}$ & \\
\hline $4 a$ & $\begin{array}{l}\text { Gray sandstone and } \\
\text { claystone. }\end{array}$ & \\
\hline 5 & $\begin{array}{l}\text { Gray sandy tuffaceous } \\
\text { claystone containing } \\
\text { conglomerate lenses. }\end{array}$ & \\
\hline 6 & $\begin{array}{l}\text { Gray tuffaceous silt- } \\
\text { stone and claystone. }\end{array}$ & \\
\hline 7 & $\begin{array}{l}\text { Gray to yellowish-gray } \\
\text { sandy granulitic } \\
\text { claystone. }\end{array}$ & \\
\hline (4) & $\begin{array}{l}\text { Orange-gray tuffaceous } \\
\text { siltstone and dirty } \\
\text { white ash bed. }\end{array}$ & \\
\hline
\end{tabular}

1 From upper part of Troublesome, primarily in Barger Gulch.

2 Identified by Peter Robinson.

4 From lower part of Troublesome in Barger Gulch.

The Miocene age of the Troublesome Formation is based on its content of mammalian vertebrates and its stratigraphic position. The formation overlies rocks dated radiometrically as latest Oligocene (p. 36) and unconformably underlies conglomerate and mudstone (p. 56) dated faunally as late Pliocene.
The lower part of the Troublesome in the region contains specimens of the oreodont Merycochoerus at locality 1 and 2 (pl. 1) and a characteristic species of the rodent Mesogaulus. The upper third of the formation in the Kremmling quadrangle contains a large fauna that includes remains of the three-toed horse Merychippus aff. $M$. sejunctus; the rhinoceros Aphelops; several types of camels, including Protolabis angustidens Aepycamelus and Oxydactylus- or Protolabis-like camels; and the mylagaulid Mesogaulus laevis. According to G. E. Lewis, who identified the fossils, the genus Merycochoerus, which occurs in the lower part of the Troublesome, is a diagnostic fossil of the Marsland Formation of the lower part of the Hemingford Group of Nebraska of Lugn (1939). Brachycrus, which occurs in the upper third of the Troublesome in the Kremmling area, is a diagnostic fossil oreodont of the Sheep Creek Formation of the upper part of the Hemingford Group of Nebraska of Lugn (1939).

During the summer of 1964 a large collection of fossil mammalian vertebrates was taken from a large landslide block in the lower part of the conglomeratic facies of the Troublesome Formation in sec. 14, T. 1 N., R. $79 \mathrm{~W}$., by a field party from the University of Colorado headed by Peter Robinson. A preliminary list of the fossils identified by Robinson was kindly given to the writer and is as follows:

"Fence locality," NW1/4 NE $1 / 4$ sec. 14, T. 1 N., R. 79 W. Metechinus marslandensis several other insectivores soricid, possibly Limnoecus sciurid cricetids, several species heteromyid geomyid Plesiosminthus sp.

?Desmatolagus sp. (identified by M. R. Dawson) mery coidodont antilocaprid

Fossils collected and identified by Robinson (written commun., 1965) from the upper part of the siltstone facies of the Troublesome Formation in the Kremmling quadrangle include:

“Beaver locality," sec. 34, T. 2 N., R. 80 W. talpid Monosaulax sp. heteromyidae, genus and species indeterminate Merychippus sp.

"Barger Gulch locality," secs. 24 and 30, T. 1 N., R. 80 W. Mesogaulus sp. Merychippus sp. ef. M. sejunctus

"Doig Ranch locality," SW1/4 sec. 22 and sec. 27, T. 2 N., R. $80 \mathrm{~W}$.

?Anchitherium sp.

large camelid

Merychippus of. $M$. sejunctus

felid, machaerodontine 
In the late 1950's, fossil mammalian vertebrates were collected from the landslide block in sec. 14, T. 1 N., R. 79 W., by Clyde Edmondson and Henry Yust of Kremmling, Colo. The small collection is now at the University of Colorado. According to Peter Robinson (written commun., 1965), the collection includes "several medium-(Eporeodon-size) sized merycoidodonts which are probaly not preserved well enough to give adequate determinations."

Cockerell (1908) was the first to report Tertiary mammals from Middle Park. He described a jaw fragment of a horse identified as Parahippus, which indicates a Miocene age. The fossil was found in a well being dug on the Stein ranch east of Barger Gulch in the $\mathrm{NE}_{1 / 4}$ sec. 24 , T. $1 \mathrm{~N}$., R. $80 \mathrm{~W}$., in the Kremmling quadrangle, in beds now assigned to the siltstone facies in the upper part of the Troublesome Formation. Richards (1941) found fossil bones identified by Case (in Richards, 1941) as titanothere only 100 yards from camel bones identified as Procamelus in beds of the Troublesome near Gunsight Pass in the Kremmling quadrangle. Richards believed, and correctly so, that the fossils were collected from one stratigraphic unit, the Troublesome Formation. The titanothere bones would indicate an early Oligocene age and the camel bones a late Miocene or Pliocene age, but the fragmentary character of the collections must have led to erroneous identifications and age assignments, because the Troublesome has yielded fossils that clearly indicate only a Miocene age in Richards' collecting area.

The assignment of the Troublesome to a specific part of Miocene time awaits solution of a complex regional problem involving confusion of nomenclature, faunal correlation, and time-stratigraphic subdivisions of Miocene rocks in classic areas of the Great Plains. This problem most recently has been summarized by McKenna (1965). Izett and Lewis (1963) assigned a middle Miocene age to the Troublesome in view of its faunal affinities to the Hemingford Group of Lugn (1939), designated by him as upper Miocene. But the rocks included in the Hemingford Group have been variously considered late Miocene by Schultz (1938, p. 444) and Lugn (1939, p. 1253-1254), middle Miocene by Wood and others (1941), late Miocene by Elias (1942, pl. 17), and middle to late Miocene by Schultz and Stout (1961). The conflicting age assignments result not so much from diverse opinion on faunal correlation as from (1) confusion of time and stratigraphic units, (2) whether a twofold or a threefold time division of Miocene is followed, and (3) lack of definitive faunal breaks associated with stratigraphic breaks in Miocene rocks. Izett and Lewis (1963), with reference to the classification of Wood and others (1941), designated the Troublesome as middle Miocene in age. But the writer and Lewis (written commun., 1966) prefer that the formation be assigned a late early and late Miocene age with reference to a twofold time division that is more consistent with the two physical rock units recognized by Darton (1903) and more recently by Sato and Denson (1967).

If a twofold stratigraphic division of the Miocene is chosen and the top of the lower division is placed at the top of the Marsland Formation of Lugn (1939), the Troublesome Formation would be lower and upper Miocene. In a threefold division of the Miocene, chosen in accordance with the usage of Wood and others (1941), the boundary between the lower and middle Miocene is placed at the base of the Marsland Formation of Lugn (1939), and the boundary between the middle and upper Miocene is placed at the base of the "lower Snake Creek" of Matthew (1924) and Schultz and Stout (1961). According to this arrangement, the Troublesome would be middle and upper Miocene. The writer believes that a twofold time division of the Miocene best suits the stratigraphic and faunal relations, although no stratigraphic break occurs in the Troublesome to mark the position of the early Miocenelate Miocene time boundary.

The Troublesome Formation probably correlates with other Miocene basin-fill deposits mapped in part by Lovering (1930) that are scattered through the lowlands of Middle Park. South of Granby, other rocks that were mapped and provisionally assigned to the White River Group of Oligocene age by Lovering (1930, p. 73) contain vertebrate fossils of Miocene age. A brief search by the writer in 1962 at a distinctive white outcrop south of Granby, Colo., revealed bone scrap at several places, but no fossils useful for dating purposes were found. In 1964 a joint collecting venture at these outcrops by Peter Robinson and the writer led to the discovery of a large collection of mylagaulid remains and other rodent bones, teeth, jaws, and skulls of Miocene age. A fragment of an oreodont jaw from the SE $1 / 4$ sec. 1 , T. 1 N., R. 77 W., has yet to be identified. The fossils await detailed study. At another locality a few miles south of Granby in the SW $1 / 4 \mathrm{SE}_{1} / 4$ sec. 24 , T. 1 N., R. 77 W., the writer found rodent teeth, and one of these fossils was identified by G. E. Lewis as Promylagaulus sp. According to Lewis it is indicative of late early Miocene age. These rocks near Granby are, in general, similar lithically to part of the conglomerate facies of the Troublesome in sec. 14, T. 1 N., R. 
$79 \mathrm{~W}$., in the Hot Sulphur Springs quadrangle. Elsewhere in Middle Park, rocks that extend from near Fraser, Colo., to Tabernash, Colo., in the Fraser basin that have been referred to as lake beds probably correlate with the Troublesome Formation. The rocks in the Fraser basin can be traced north from Tabernash to the top of the divide that separates the Granby and Fraser basins, and these rocks were probably once continuous from the Granby basin to the Fraser basin. No fossils diagnostic of age have been found by the writer in the "lake beds" of Fraser basin, but Peter Robinson (written commun., 1964) found a toothless jaw fragment at Tabernash that "is probably a Merycoidodont, and if so, is too large for the Oligocene species of the family Merycoidodontidae and is probably postOligocene in age."

The Troublesome Formation is lithically similar to and probably correlates with a tuffaceous sequence of fluvial Miocene deposits in North Park, Colo., that is referred to as North Park Formation. The occurrence of white biotitic ash beds severul hundred feet above the base of the Troublesome in the Kremmling area and a similar ash bed 2-3 feet thick about 500 feet above the base of the North Park Formation in the

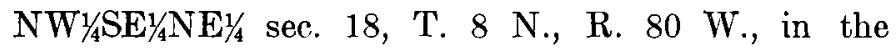
North Park syncline is the basis of correlation. Fossils from the North Park indicate a rather wide age span from middle Miocene to late Miocene (McGrew, 1951; 1953, p. 63-64; Montagne, 1955; Montagne and Barnes, 1957; and Hail and Lewis, 1960). A Pliocene age for the upper part of the North Park was suggested by Montagne and Barnes (1957, p. 59). The Troublesome probably correlates in part with the Browns Park Formation of Miocene(?) age in Colorado and Wyoming, but details of correlation await regional stratigraphic and paleontologic studies of the Browns Park. The Troublesome probably correlates with Miocene rocks (Pawnee Creek Formation of Galbreath (1953)) below the Ogallala Formation caprock of northeastern Colorado, but details of faunal correlation await completion of study of the vertebrates of the Troublesome by G. E. Lewis and Peter Robinson.

\section{ASII BEDS}

The Troublesome Formation is generally tuffaceous, and west of the mapped area, in the Kremmling quadrangle, the formation contains beds of nearly pure volcanic ash in at least 15 stratigraphic levels. The ash beds range in thickness from 0 to 5 feet and can be traced for only short distances along the outcrop. Some of the ash beds are fluffy and fresh appearing, whereas others are contaminated and well indurated because of alteration. One ash bed designated the "CW" ash (chalky white) occurs in a zone of white ash beds in the lower part of the Troublesome Formation. Olive-gray ash beds occur in zones in the upper part of the formation. These ash beds in the Troublesome Formation in the Kremmling quadrangle are currently (1966) being studied by the writer. The ash beds may be significant regional marker beds, but before correlations based on these beds are certain, petrographic and chemical features and detailed stratigraphy of all upper Tertiary ash beds in the Western Interior must be studied. The possibility that petrographic and chemical properties are duplicated in a zone of ash beds within a particular rock sequence demands extreme caution when correlating ash beds on a regional scale (Wilcox, 1965).

Figure 18 shows the writer's interpretation of correlation of Miocene rocks in Colorado, Nebraska, and Wyoming based on fossil vertebrates, lithic similarity, and certain zones of ash. The correlations are extremely tentative and await completion of study of samples of ash beds collected by the writer in Colorado, Nebraska, and Wyoming. A twofold division of Miocene time based on the range of the horse Merychippus is shown in figure 18. The diagrams taken from McKenna (1965) and Cady and Scherer (1946) are not strictly time diagrams, but they are shown to present the views of these authors on stratigraphic succession of Miocene rocks in western Nebraska.

Several white biotitic ash beds in the lower part of the Troublesome in the Kremmling quadrangle contain glass-mantled phenocrysts of euhedral allanite $\left(\mathbf{n}_{\mathbf{x}}=\right.$ $1.780)$ as well as magnetite, ilmenite, biotite, apatite $\left(\mathrm{n}_{\mathrm{e}}=1.640\right)$, oligoclase, quartz, sanidine $\left(2 \mathrm{~V}_{\mathrm{x}}=15-22\right)$, hornblende, sphene, and zircon. The minerals were identified using the spindle stage of Wilcox (1959). The hydrated glass shards have an index of refraction that varies little from 1.496-1.498 and are charged with abundant second-order gas-filled vesicles. The refractive index of the glass was measured using the focal masking technique described by Cherkasov (1957) and Wilcox (1962). Major petrographic features of the white biotitic ash beds are the biotite (pale yellow), the euhedral allanite showing abnormal dispersion and absorption, the small optic angle of the sanidine, and the refractive index of the glass. Small amounts of rounded detrital minerals derived from older formations include hornblende, oxyhornblende, epidote, and augite. Chemical analyses of the ultrasonically scrubbed glass of the $\mathrm{CW}$ ash from the Troublesome and a similar ash in the North Park Formation are given below: 


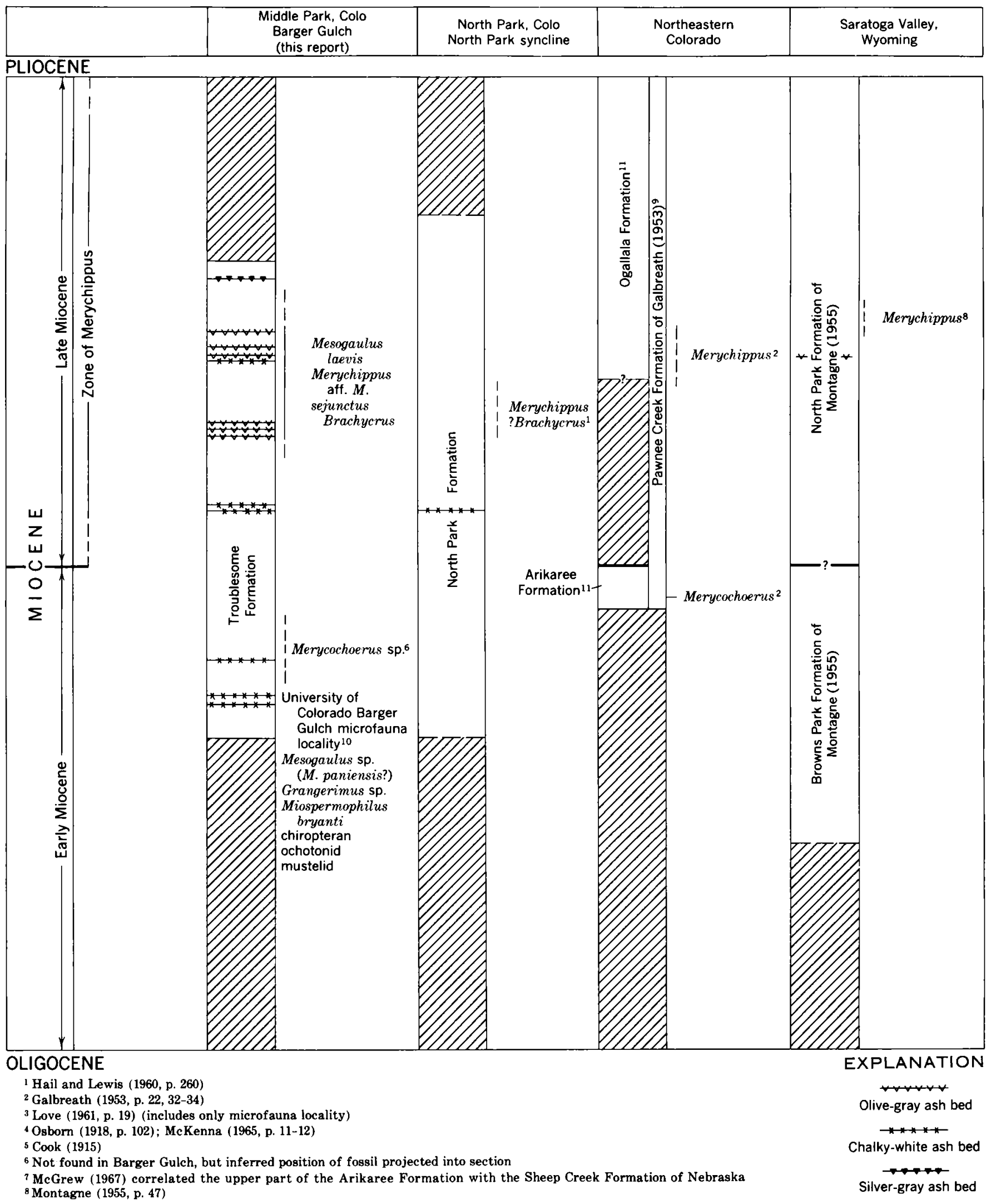

Frgure 18.-Correlation diagram showing an interpretation of time relations of 


\begin{tabular}{|c|c|c|c|c|c|}
\hline $\begin{array}{l}\text { Split Rock area, } \\
\text { Wyoming }\end{array}$ & $\begin{array}{l}\text { Casebier Hill } \\
\text { quadrangle, } \\
\text { Wyoming }\end{array}$ & $\begin{array}{c}\text { Merychippus Draw, } \\
\text { Sioux County, } \\
\text { Nebr }\end{array}$ & $\begin{array}{l}\text { Agate Spring fossil } \\
\text { quarry and vicinity. } \\
\text { Sioux County, Nebr }\end{array}$ & $\begin{array}{c}\text { Northwestern } \\
\text { Nebraska } \\
\text { (modified after } \\
\text { McKenna, 1965) }\end{array}$ & $\begin{array}{l}\text { Box Butte County, } \\
\text { Nebraska } \\
\text { (after Cady and } \\
\text { Scherer, 1946) }\end{array}$ \\
\hline
\end{tabular}

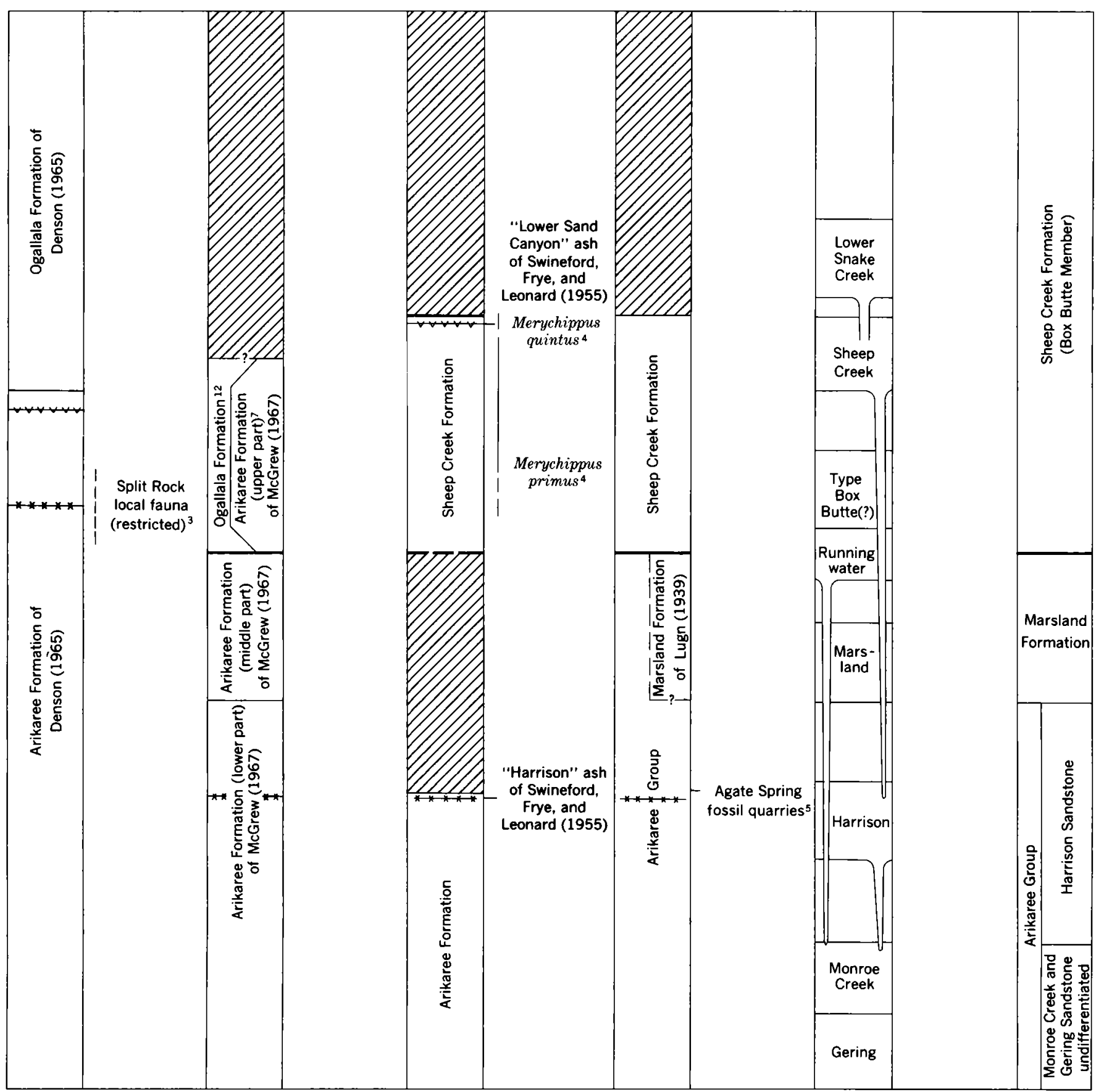

9 "In northeastern Colorado, rocks assigned to the Pawnee Creek Formation by Galbreath (1953) are Ogallala, except at Martin Canyon where he included the so-called 'Martin Canyon beds' in the 'Pawnee Creek' " (N. M. Denson, written commun., 1966)

${ }^{10}$ See reference section of Troublesome Formation, unit 9 , in text

"Sato and Denson (1967)

12 Ogallala Formation of Matthew and Cook (1909, p. 363, lines 8-9) and Matthew (1924, p. 61)

Miocene rocks in Middle Park, Colo., and selected areas in Colorado, Nebraska, and Wyoming. 
Chemical analyses of the "CW" ultrasonically scrubbed glass and glass from a white ash in the North Park Formation

[Analyses made by atomic absorption techniques by Claude Huffman, Jr., and J. D. Mensick, Jr., except where noted]

\begin{tabular}{cc}
\hline Troublesome Formation & North Park Formation \\
unit 13, reference section, & North Park syncline, Peter- \\
lower Barger Gulch; SW1/4 & son Ridge; NW1/4SE1/4NE1/4 \\
sec. 24, T 1 N., R. 80 W.; & sec. 18, T.8 N., R. 80 W.; \\
Sample No.65G35 & sample No. 65G55
\end{tabular}

\begin{tabular}{|c|c|c|}
\hline 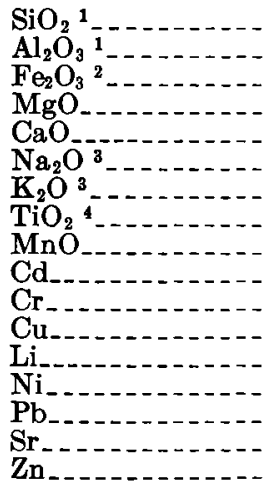 & $\begin{array}{l}73.8 \\
11.9 \\
.58 \\
.065 \\
.62 \\
\text { 2. } 41 \\
5.46 \\
.08 \\
.048 \\
<.0004 \\
<.001 \\
<.001 \\
.0004 \\
<.0015 \\
.005 \\
.008 \\
.0029\end{array}$ & $\begin{aligned} 74.0 \\
11.2 \\
.53 \\
.11 \\
.57 \\
\text { 1. } 52 \\
6.91 \\
.10 \\
.063 \\
<.0004 \\
<.001 \\
<.001 \\
.0009 \\
<.0015 \\
.005 \\
.007 \\
.0029\end{aligned}$ \\
\hline $\begin{array}{l}\text { Sum } \\
\text { (rounded) - }\end{array}$ & 95 & 95 \\
\hline
\end{tabular}

1 Colorimetric technique; analyst, G. T. Burrow.

2 Total iron as $\mathrm{Fe}_{2} \mathrm{O}_{3}$.

Fountioy.

1 Titron method; analyst, G. T. Burrow.

The ultrasonically scrubbed glass separated from the minerals by bromoform is rhyolitic as shown by its high silica and alkali contents and its low iron and magnesia contents. The glass contains about 4.4 percent water (determined as part of chemical analysis of the glass made by P. Elmore, G. Chloe, H. Smith, D. Taylor, L. Artis, S. Botts, and J. Glenn, all of the U.S. Geological Survey).

Inspection of the major-oxide content shows a similarity between the two hydrated glasses, and the minor differences between some oxides of the two glasses probably resulted from changes accompanying hydration. Sodium has probably been leached from and potassium added to the glass during hydration as shown by the low $\mathrm{Na}_{2} \mathrm{O}-\mathrm{K}_{2} \mathrm{O}$ ratios. The amount of certain refractory constituents in the two glasses such as iron, titanium, and zinc shows good agreement, but the amount is appreciably different from that in olive-gray ash in the Troublesome (p. 51). The chemical and mineralogic similarity of the two white ash samples is striking, but stratigraphic and faunal relations suggest that the samples are not part of the same ash fall.
The CW ash bed in the lower part of the Troublesome Formation is similar to a chalky white biotitic ash bed 30 feet below the Agate Spring fossil quarries in the $\mathrm{SE}^{1 / 4} \mathrm{NW}^{1 / 4}$ sec. 10 , T. 28 N., R. 55 W., Sioux County, Nebr. The ash is about 170 feet above the base of the Arikaree Formation of Miocene age a few miles east of Agate, Nebr., according to N. M. Denson (written commun., 1966), and has been dated as about 21.3 m.y. old by Evernden, Savage, Curtis, and James (1964, p. 178). The CW ash is similar to the Harrison ash of Swineford, Frye, and Leonard (1955) in the Arikaree Group at Pliohippus Draw in the NE1/4 sec. 31, T. 26 N., R. 55 W., Sioux County, Nebr.; to a chalky white biotitic ash in the Arikaree Formation of Miocene age below the "middle zone" of the "Split Rock local fauna" in the Split Rock area of Wyoming described by Love (1961, p. 19, unit 2); and to a chalky white biotitic ash 190 feet above the base of the Arikaree Formation in sec. 34, T. 27 N., R. 64 W., Casebier Hill quadrangle, Wyoming. The samples of the ashes have a similar refractive index of the hydrated glass $(n=$ 1.496-1.497), a common assemblage of glass-mantled phenocrysts, and common shard characteristics. Although these ash beds are similar mineralogically and chemically and occur in a fairly narrow stratigraphic range in Miocene rocks, they probably are not all the same ash fall but represent successive ash falls from recurrent explosive volcanism in the source area.

An olive-gray volcanic ash bed occurs at a roadcut near Williams Fork Reservoir in the N1/2 sec. 34, T. 1 N., R. 79 W., as a lens of fluffy ash about 2 feet thick in the upper part of the siltstone facies. This ash is similar to a zone of ash beds in the reference section of the formation (units 28 and 30, p. 52). Under the microscope the ash is mostly flaky glass shards formed from large bubble walls. The shards are as much as $0.1 \mathrm{~mm}$ in diameter. Many of the shards appear fresh but a few show faint thin birefringent borders even after ultrasonic scrubbing. Most of the shards are colorless, but a few are various shades of brown; the mixture of clear and brown shards gives the ash a salt-and-pepper appearance under the microscope. The brown shards are more magnetic than the clear shards, apparently due to finely disseminated iron oxides. The hydrated glass has a mean refractive index of about 1.505 and a range from about 1.502 to 1.528 . A partial chemical analysis of ultrasonically scrubbed glass separated from quartz, feldspar, and heavy minerals of the ash follows: 
Partial chemical analysis of ultrasonically scrubbed glass separated from quartz, feldspar, and heavy minerals of an olive-gray ash near Williams Fork Reservoir

Analyses by G. T. Burrow, Claude Huffman, Jr., J. D. Mensick, Jr., and Wayne Mountioy of the U.S. Geol Survey, by atomic absorption and flame photometer techniques except where noted]

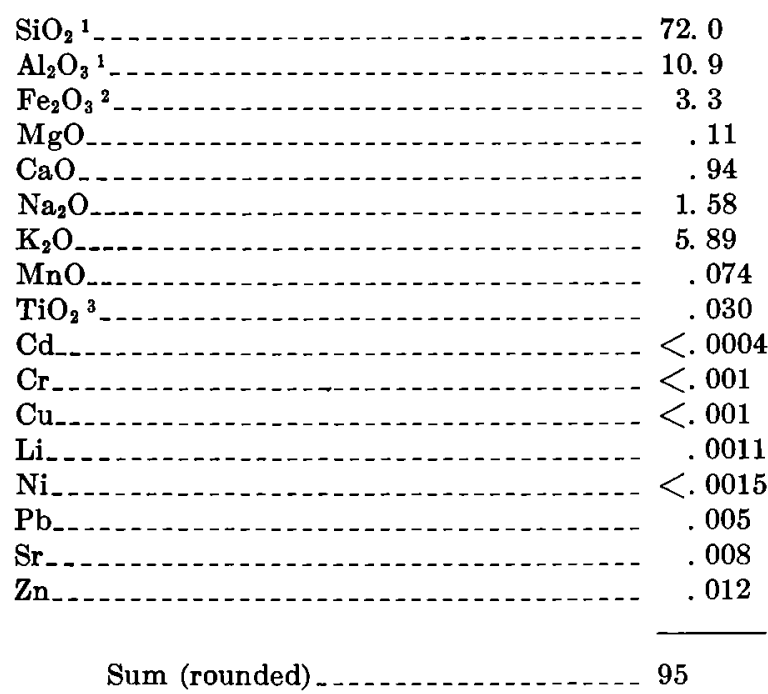

$1 \mathrm{By}$ colorimetric technique.

2 Total iron as $\mathrm{Fe}_{2} \mathrm{O}_{3}$.

3 By titron method.

The glass is rhyolitic to quartz latitic as shown by its high silica and alkali contents, and it contains significant amounts of iron. Although the water content of the ash was not directly determined, the glass is certainly hydrated, as shown by the difference between the sum of the oxides and 100 percent (about 5 percent). The water content of the glass as determined on some samples of olive-gray ash as part of chemical analyses is about 5.1 percent. The rather high $\mathrm{K}_{2} \mathrm{O}$ content and the low $\mathrm{Na}_{2} \mathrm{O}$ content of the glass suggest that some $\mathrm{Na}_{2} \mathrm{O}$ may have been leached and some $\mathrm{K}_{2} \mathrm{O}$ added. Lipman (1965) and Aramaki and Lipman (1965) presented evidence that $\mathrm{Na}_{2} \mathrm{O}$ is leached and $\mathrm{K}_{2} \mathrm{O}$ commonly is added during hydration of natural glasses.

Phenocrysts, separated from the olive-gray ash by bromoform, that are mantled with glass of the same refractive index as the glass of the bulk ash and that were almost certainly deposited with the air-fall ash include magnetite, ilmenite, apatite, zircon, sanidine $\left(2 \mathrm{~V}_{\mathrm{x}}=45 ; \mathrm{n}_{\mathrm{y}}=1.529\right)$, and oligoclase $\left(\mathrm{n}_{\mathrm{y}}=1.544 ; 2 \mathrm{~V}\right.$ large). Chevkinite was found in several olive-gray ash beds a few miles west in the Kremmling quadrangle. The listed minerals are euhedral with the exception of sanidine and oligoclase, which are cleavage fragments. Minerals that may be phenocrysts but that could not definitely be related to the ash by the criterion of being glass mantled are olivine $\left(\mathrm{F}_{0_{50-60}}\right)$ and hypersthene $\left(\operatorname{En}_{63}\right)$. Detrital minerals occur in small amounts.
These minerals include a few rounded grains of epidote and garnet and cleavage fragments of green hornblende.

Some olive-gray ash beds in the upper part of the Troublesome are similar to the prominent olive-gray ash in the Sheep Creek Formation of Nebraska at the head of Merychippus Draw in the NE/4 $\mathrm{SE}_{4} / 4$ sec. 30, T. 26 N., R. 55 W., Sioux County, Nebr., (McKenna, 1965 , p. 11-12) and are similar to an olive-gray ash in the North Park Formation in the $\mathrm{SW}_{4} / \mathrm{NE}_{4} / 4$ sec. 17, 'T. 15 N., R. 83 W., Carbon County, Wyo. According to N. M. Denson (oral commun., 1966), the ash in Wyoming is about 800 feet above the base of the North Park Formation. The refractive index of the shards ranges from 1.502 to 1.528 and averages about $n=1.505$. Other characteristics common to the ash beds in these localities are their locally coarse grain size, their saltand-pepper appearance due to the presence of clear and dark-brown shards, and their general chemical composition. The ash in Merychippus Draw was dated 14.7 m.y. by Evernden, Savage, Curtis, and James (1964, p. 184).

Speculation concerning the source of the silicic ash beds in the Troublesome Formation and similar ash beds in Miocene rocks elsewhere in Colorado, Nebraska, and Wyoming leads to consideration of nearby volcanic centers in Colorado. The vents that fed the Rabbit Ears Volcanics in the Rabbit Ears Range were active in late Oligocene time (Izett, 1966) and probably did not contribute air-fall ash to the Miocene sediments. Elsewhere in Colorado, several Tertiary volcanic vents including the Creede Caldera (Steven and Ratté, 1960) in the San Juan Mountains might be considered a source area owing to the large amount of silicic to intermediate tuffs that were extruded. However, according to Steven, Mehnert, and Obradovich (1967, p. D53), potassiumargon dates show that the bulk of the intermediate to silicic tuffs in the San Juan Mountains were probably extruded by the end of Oligocene time (25 m.y.). Small volumes of silicic tuffs were erupted from local vents during early Miocene time, but the probability that the San Juan Mountains volcanic centers contributed significant amounts of ash to the Miocene rocks is small. Specimen Mountain in Rocky Mountain National Park is a middle Tertiary volcanic center, but silicic tuffs in the Mount Richthofen-Iron Mountain area that may be the same age as those at Specimen Mountain were dated as late Oligocene (27-28 m.y.) by Corbett (1965).

The Yellowstone Park area is a possible source area for the Miocene ash beds, but not enough is known concerning the timespan of extrusion of the silicic tuffs that abound in the area. Volcanic centers such as Timber Mountain Caldera (Hinrichs and Orkild, 1961; Byers and others, 1964) in southern Nevada and other such volcanic centers in southern and central Nevada are 
known to have extruded extremely large amounts of silicic to intermediate tuffs in Miocene time and are likely source areas for the Miocene ash beds in northern Colorado, western Nebraska, and Wyoming.

Reference section of Troublesome Formation in lower Barger Gulch in the $S 3 / 2$ sec. 24, T. 1 N., R. $80 \mathrm{~W}$., and the $S W 144$ sec. 19 , T. 1 N., R. $79 \mathrm{~W}$.

[Measured by planetable and hand level $\ln 1965$ by G. A. Izett and R. Trengove]

Top of hill, east side of Barger Gulch.

Thickness

43. Siltstone, orange-gray, clayey, silty, locally limy and case hardened; forms slopes and ledge

42. Ash, silver-gray, locally case hardened; forms ledge.

41. Siltstone, orange-gray, clayey, sandy, locally limy and case hardened; forms slope and ledges.......

Offiset 1,000 ft southeast.

40. Ash, gray, lenticular, impure; forms slope

39. Siltatone, orange-gray, clayey, sandy, locally limy; forms slope

38. Ash, gray, impure, lenticular; contains horse mandible; forms slope. . . . . . . . . . . . . . . . .

37. Siltstone, orange-gray, clayey, sandy, locally limy; contains dirty ash lens in lower part of unit; forms

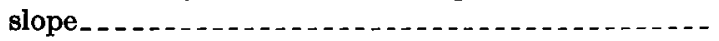

36. Ash, olive-gray, lenticular, locally case hardened; grades upward into siltstone

35. Siltstone, orange-gray, clayey, sandy, locally limy; contains fossil camel remains near base of unit... -

34. Ash, white, biotitic, fluffy, lenticular; contains fossil horse remains................................

33. Siltstone, orange-gray, clayey, sandy, locally limy; contains several dirty ash lenses in lower part of unit; contains many fossil vertebrate remains including remains of Brachycrus..............

32. Ash, olive-gray, locally case hardened; contains many fossil mammal vertebrate remains. ............

Offset to Barger Gulch in the SE1/4 sec. 24, T. 1 N., R.

$80 \mathrm{~W}$. , and the SWY $/ 4$ sec. 19 , T. 1 N., R. 79 W.

31. Siltstone, orange-gray, clayey, limy; thickness uncertain owing to covered area...............

Offiset to east, using olive-gray ash beds as marker beds, across Barger Gulch road.

30. Ash, olive-gray, case-hardened; forms ledge

29. Siltstone, partly covered, orange-gray; contains scattered clay limestone ledges; contains a few silica concretions about 8 in. in diameter; caps small hill; contains many vertebrate remains including Merychippus, Brachycrus, and camels; forms slope on small hill.

28. Ash, olive-gray, locally case-hardened and indurated; fresh ash is fluffy and very fine grained; forms weak ledge.

27. Siltstone, orange-gray, clayey, limy; contains lenticular impure brownish-gray limestone beds about $2 \mathrm{ft}$ thick

26. Limestone, impure, silty, clayey, flaggy to massive; contains clay galls; is locally chertified; forms minor ledge.

25. Siltstone, partly covered, orange-gray to orangebrown; contains a few thin chert beds that weather and litter slopes; weathers to gentle "soft" slopes as contrasted with underlying units which weather to "hard" clean slopes.

25. 0
Reference section of Troublesome Formation in lower Barger Gulch in the $S 1 / 2$ sec. 24, T. 1 N., R. $80 \mathrm{~W}$, and the $S W 1 / 4$ sec. $19, T .1$ N., R. $79 \mathrm{~W}$. -Continued

24. Ash, chalky-white, impure; limy at base; altered to pink montmorillonite; forms ledges............

23. Siltstone, orange-gray, clayey; forms slope

22. Ash, light-grayish-brown to white, impure (silty and clayey); contains clay galls; weathers to white rough

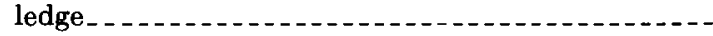

21. Siltstone, orange-brown, clayey, structureless; weathers to clean "hard" slopes. . . . . . . . . . . . . . .

70. 0 20. Ash, greenish-brown, impure, indurated; forms minor ledge.

1. 0

9. 0

26. 0

19. Siltstone, orange-brown, clayey; covered in lower part; weathers to clean "hard" slopes............

18. Siltstone, tuffaceous; like unit 14 ; forms slope

17. Siltstone, orange-brown; like unit 15 ; weathers to bare slope.

48. 0 16. Siltstone, light-greenish-gray, tuffaceous, clayey, punky; has fairly sharp contact with underlying

unit; forms ledges; contains glass shards....... 0 15. Siltstone, orange-gray to brown, clayey, structureless,
15. hard; contains a few iron-rich concretions; weathers to bare "hard" slope.

14. Partly covered; lower $20 \mathrm{ft}$ is orange-brown structureless siltstone that weathers to "hard" clean slopes; several paleosols have been inferred from color relation of siltstone; dirty white ash bed about $1 \mathrm{ft}$ thick at top of unit.

13. $\mathrm{CW}$ ash, light-gray, locally indurated, lenticular, biotitic; base of unit paleosol; forms ledge

12. Siltstone, orange-brown, clayey, structureless; reddish brown and well indurated at top of unit (paleosol); ashy in upper part; weathers to clean "hard" slopes_......................................

3. 0 11. Ash, light-gray, dirty, punky, lenticular; weathers to rounded slope.

10. Siltstone, orange-brown, clayey, hard, structureless; top of unit probably a paleosol; locally yellowish brown to reddish brown near top of paleosols; forms smooth clean "hard" slopes.

9. Ash, white, altered, dirty, lenticular; grades upward into siltstone; University of Colorado Museum Barger Gulch micromammalian fossil locality in this unit; fossils, identified by Peter Robinson include Mesogaulus sp. (M. paniensis?), Grangerimus sp., Miospermophilus bryanti, chiropteran, ochotonid, and mustelid.

8. Siltsone, orange-brown; like unit 10

7. Ash, white, impure, lenticular; contains a few rodent

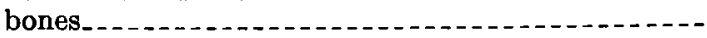

6. Limestone, grayish-brown, lenticular, impure, silty,

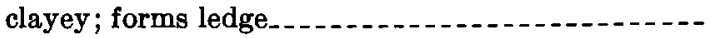

5. Siltstone, orange-brown; like unit 10

4. Limestone, light-brownish-gray, impure, silty, lenticular; forms ledge.

3. Siltstone, orange-brown, clayey, slightly limy, structureless; forms slope..........................

2. Ash, white, altered; weathers to white fluffy surface.-

1. Covered, base of Troublesome not exposed. Total measured Troublesome Formation. 
Partial section of the Troublesome Formation in upper Barger Gulch in the NW14 sec. $30, T .1 N$., R. $79 W$., Kremmling quadrangle

[Measured by G. A. Izett and W. H. Laraway, 1963]

Thickness $(f t)$

Top of section, elevation $7,800 \mathrm{ft}$.

Troublesome Formation (part) :

14. Siltstone, light-orange and light-greenish-gray, tuffaceous, clayey, structureless; contains intercalated earthy limestones as much as $2 \mathrm{ft}$ thick, and intercalated thin chert beds less than $0.3 \mathrm{ft}$ thick; top of unit is top of hill; rodent jaw fragment found $55 \mathrm{ft}$ above base of unit; camel jaw fragment and assorted bones found $45 \mathrm{ft}$ above base of unit

13. Ash, light-gray, impure, mixed with orange-gray siltstone, limy, locally case hardened; forms slopes and ledges..........................

12. Siltstone, light-orange-gray, tuffaceous, clayey, soft; contains a few intercalated limestones; forms slopes and ledges.

11. Chert, white to gray, hard, lenticular; forms ledges......................................

10. Siltstone, like unit 8.

9. Chert, white to gray, hard, lenticular; forms

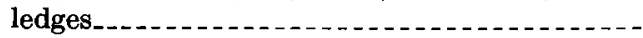

8. Siltstone, light- to medium-orange-gray, structureless, clayey, tuffaceous; contains a few scattered pipy concretions; contains irregularbedded rough-weathering earthy limestones; weathers to pebbly hard surface; forms slopes. -

7. Ash, light-gray, lenticular, impure; forms slopes.-

6. Siltstone, light-orange-gray, nonlimy, structureless, clayey, tuffaceous; contains irregular lenses of earthy limestone with stringers of mud pebble conglomerate; forms slopes and ledges..

5. Limestone, light-orange-gray, dense, earthy, rough-weathering, clayey, silty; forms ledge. -

4. Siltstone, light-orange-gray, tuffaceous, structureless, clayey, fairly hard; locally contains earthy limestone lenses; contains a few fossil mammalian vertebrate scraps; forms slopes and ledges.

3. Ash, light-gray, soft but locally case-hardened; contaminated with some siltstone; lenticular flaky shards common; forms slope. .........

2. Siltstone, light-orange-gray, tuffaceous, nonlimy, clayey, fairly soft, structureless; locally contains thin stringers of mud pebble conglomerate; forms slope.

1. Limestone, light-gray, hard and dense; contains few glass shards; forms ledge . . . . . . . ......

Base of Troublesome Formation not exposed. Section begins at bottom of gulch.

Total measured Troublesome Formation (rounded) _ 218

GROUSE MOUN'TAIN BASALT AND RELATED DIKES

Olivine-bearing basalt flows and interlayered tuffaceous sediments cover about 7 square miles of uplands north of the Colorado River and west of Elk Mountain. The lavas and associated tuffaceous sediments are as much as 300 feet thick and were named the Grouse Mountain Basalt by Izett (1966) for good exposures at Grouse Mountain in sec. 18, T. 2 N., R. 78 W. The unit is the youngest volcanic rock in the area and is probably Pliocene in age. The basalt flows generally dip west to southwest and were extruded from vents to the north and northeast onto a dissected surface of considerable relief. In the quadrangle the Grouse Mountain generally rests on the Rabbit Ears Volcanics, but locally it rests on the Troublesome Formation or older rocks.

The lava flows that make up a large part of the Grouse Mountain show features common to other described basalt flows. Individual flows range from black to brown and in some places show scoriaceous oxidized upper and lower surfaces. Pillowlike lavas formed in sec. 16, T. 2 N., R. 79 W., where thin flows were probably extruded over soft wet sediments of the Troublesome Formation. Red, brown, and yellow jasper fragments are scattered over some of the basalt outcrops. The basalt contains many amygdules of quartz and calcite. The tuffaceous sediments associated with the basalts are generally soft and clay rich and crop out mainly along Corral Creek in sec. 36, T. 2 N., R. 79 W.

The Grouse Mountain is no older than very latest Miocene, for it locally overlies the Troublesome Formation of early to late Miocene age; but an upper age limit for the Grouse Mountain cannot be stratigraphically determined because no other rocks overlie the formation. Until the age of the Grouse Mountain can be established, it is provisionally dated as Pliocene.

Hand samples of the lava are generally dark brownish gray to black. The rock contains widely separated small olivine phenocrysts as much as $3 \mathrm{~mm}$ long set in an aphanitic groundmass. The lava generally is altered to shades of brown or gray; some weathered surfaces show a characteristic spotted pattern. Olivine insets are commonly altered to sof tmicaceous masses of saponite(?).

Under the microscope the texture of the lava is seen to be mainly intersertal and to consist of flow-oriented zoned plagioclase laths $\left(\mathrm{An}_{35-55}\right)$ as much as $0.5 \mathrm{~mm}$ long, granular augite $\left(\mathrm{n}_{\mathrm{y}}=1.705 ; 2 \mathrm{~V}_{\mathrm{u}}=54-57\right)$, acicular apatite, and iron oxides. Some saponite(?) pseudomorphs after olivine are scattered through the matrix. Low birefringent minerals in the matrix probably are alkali feldspar, analcime, and a purplish isotropic mineral $(n \approx 1.460)$ that is probably chlorophaeite. A biaxial negative mineral that apparently has a small optic angle could either be alkali oligoclase (MacDonald, 1942) or twinned plagioclase. Alteration products are calcite, quartz, and zeolites. Olivine phenocrysts are euhedral, and many are altered to a waxy micaceous mineral with a low negative optic angle that might be saponite, whereas fresh olivine is nearly colorless and as much as $1.5 \mathrm{~mm}$ in diameter. Optical properties of some minerals in the basalt are listed in 
table 7. Xenocrysts of resorbed plagioclase are widely scattered through the matrix. Clots of clinopyroxene that show a crude radial configuration probably formed as reaction products from the assimilation of quartz xenocrysts.

Results of chemical analysis and calculated normative minerals of the lava are shown in table 8 . The analyses show that the lavas are characterized by significant amounts of $\mathrm{K}_{2} \mathrm{O}$. Chemical analyses of the Grouse Mountain Basalt are roughly similar to analyses of mugearite listed by Tröger (1935, p. 128), to the average of analyses of volcanic equivalents of Hurumtype mangerites tabulated by Nockolds (1954, p. 1018), and to the average alkali basalts tabulated by Engel, Engel, and Havens (1965, p. 721).

Intrusive masses of basalt that are petrographically similar to the Grouse Mountain Basalt flows are exposed at two places in the quadrangle. At Corral Peaks the basalt forms a composite mass composed of two dikes and a connecting sill-like body that cuts the Rabbit Ears Volcanics. The dikes form the northeastern and southwestern outcrops of the composite body. The northeastern dike averages about 100 feet in thickness and trends northwest; the southwestern dike is much thicker. The contact between the basalt and the Rabbit Ears is generally covered, but the walls of the dike are steep, and the contact is probably nearly vertical. Cooling joints in the basalt along the northeastern dike are roughly horizontal and formed normal to the largest cooling surface, which must have been the Rabbit Ears wallrock. Figure 19 shows the dike and the cooling joints. The basalt is brittle and splintery and in some places breaks into wedge-shaped pieces. Traced southwestward, the dike passes in to a sill-like body more than 100 feet thick that clearly intrudes the Rabbit Ears Volcanics. The contact is well exposed below the southwest of the two peaks that form Corral Peaks, and cooling joints there are roughly normal to the floor of the sill-like body. The age of the basalt is not exactly known, but because the basalt cuts the Rabbit Ears and is probably related to the Grouse Mountain lavas, it is tentatively dated as Pliocene.

Fresh hand samples of the intrusive basalt are dark gray to black, but weathered surfaces are brown. With the aid of a hand lens, a few scattered olivine phenocrysts can be seen; they are set in an aphanitic groundmass.

Study under the microscope shows that the rock is composed of moderately iron-rich olivine phenocrysts partly altered to saponite(?) about $2 \mathrm{~mm}$ long set in a holocrystalline groundmass of unoriented calcic andesine laths, granular augite, iron oxide, and ilmenite. Optical properties of some of these minerals are listed in table 7 . The groundmass contains acicular apatite.

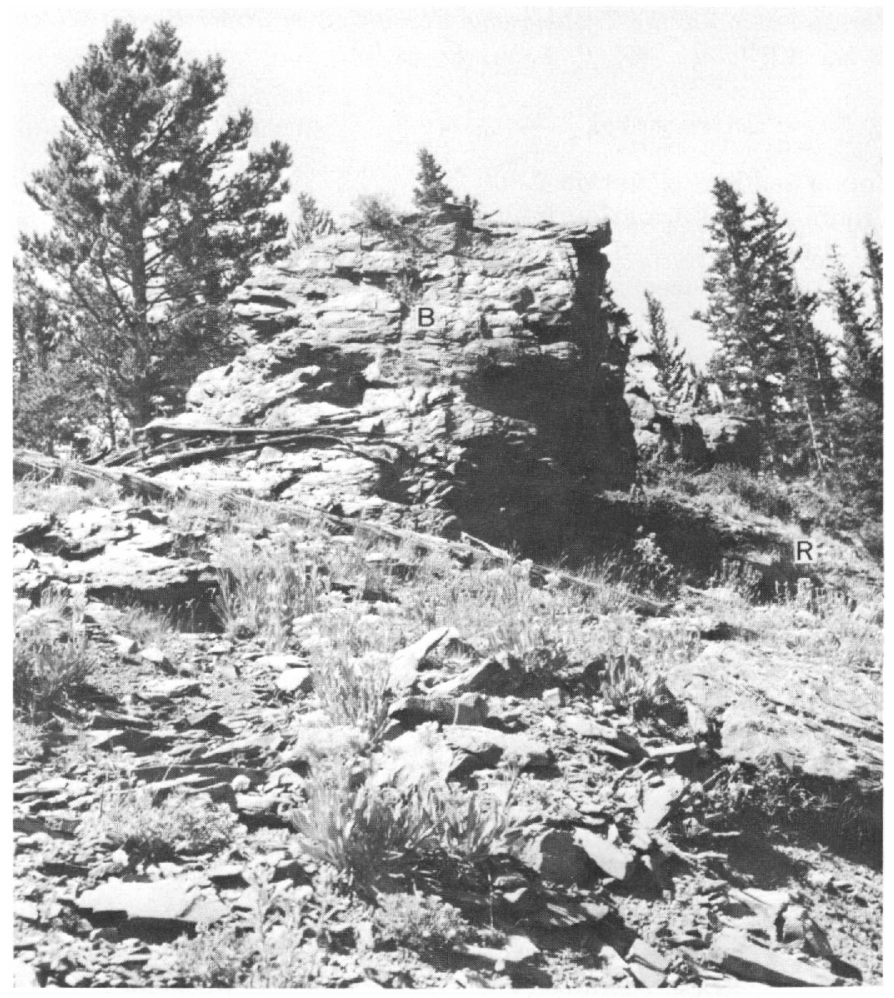

Frgure 19.--Basalt dike cutting Rabbit Ears Volcanics at Corral Peaks. Cooling joints normal to walls of dike. B, basalt; $R$, Rabbit Ears Volcanics.

The basalt differs from the other basalts in the area in that it contains olivine slightly richer in iron and has a much coarser groundmass. A chemical analysis of the lava and its computed normative minerals are listed in table 8 , column 19 . The analysis shows that the rock is an undersaturated basaltic rock that chemically is similar to the "all basalt" average of Daly $(1933$, p. 17) and lies between the average andesite of Nockolds (1954, p. 1019, col. 2) and the average plateau basalt of Daly (1933, p. 17).

Dikes of olivine-bearing basalt intrude the Middle Park Formation along Little Muddy Creek in sec. 21, T. 1 N., R. $78 \mathrm{~W}$. The Middle Park is altered and bleached for short distances away from the walls of the plugs, and conglomeratic sandstone fragments of the Middle Park, as much as 2 feet in diameter, are included in the basalt. The basalt near the steeply dipping contact is chilled, contains amygdules of calcite, and shows onionskin exfoliation.

Field relations at one place suggest that basalt flows related to the basalt dikes along Little Muddy Creek rest on an erosion surface cut on the Middle Park Formation and underlie the Troublesome Formation. Accordingly, the age of the basalt would be post-Middle Park Formation and pre-Troublesome Formation, but 
the pertinent outcrops are near a large landslide block, and the age relations are equivocal.

Hand samples of the freshest basalt from along Little Muddy Creek are dark bluish black to brownish black and contain small scattered olivine and pyroxene phenocrysts set in an aphanitic groundmass. Under the microscope the olivine phenocrysts are nearly colorless, euhedral, and altered and are about $0.7 \mathrm{~mm}$ long. Other phenocrysts are colorless stubby prisms of fresh augite that are about $0.5 \mathrm{~mm}$ long. The matrix consists of flow-oriented zoned plagioclase laths, augite, iron oxide, analcite ( \pm 10 percent), and small amounts of alkali feldspar. Optical properties of some of these minerals are listed in table 7 . Corroded quartz xenocrysts show reaction rims of augite, calcite, and saponite(?). Where assimilation of xenocrysts is complete, large masses of oriented augite are surrounded by halos rich in carlsbad-twinned monoclinic alkali feldspar laths. Sandstone xenoliths are altered and contain blebs of partly hydrated glass. Acicular apatite and alteration products including saponite, calcite, zeolites, and chlorophaeite are common in the groundmass. Chemical analyses and the computed normative minerals of the rock (table 8, col. 20) show that the rock is basaltic and is similar to the basalt intrusive at Corral Peaks except that it contains a little more silica and potassium.

BOULDER CONGLOMERATE OF GRAVEL MOUNTAIN

Deposits of conglomerate that lie on truncated moderate to steeply upturned beds in the Middle Park Formation and that contain conspicuous large boulders were mapped in the northeast corner of the quadrangle. The deposits are probably of late Tertiary age. They are also exposed about 2 miles northeast of the mapped area in the Bowen Mountain quadrangle. The deposits cap the tops of mountains more than 11,000 feet high, such as Gravel Mountain, and can be followed down ridges that extend into Middle Park to altitudes of about 9,600 feet.

In the Hot Sulphur Springs quadrangle the character of the deposits is obscured by a thick soil mantle and dense stands of timber. The gravel, however, can be traced in a general way through the woods by concentrations of large boulders that project through the soil mantle, although patches of boulders that either were let down from a higher surface or are residual boulders from weathered Middle Park Formation locally could have been mapped with the gravel. Good exposures of as much as 500 feet of gravel were studied in the adjoining Radial Mountain quadrangle at Little Gravel Mountain and Gravel Mountain. The gravel consists of granules, pebbles, cobbles, and boulders set in a sandy matrix. Most of the boulders, some of which are as much as 14 feet in diameter, are pink medium-grained granitic rock of Precambrian age, and a few are metamorphic rocks of Precambrian age. The roundness of the large boulders of granitic rock that are exposed on the surface of the deposits has been accentuated by spheroidal weathering. The gross aspect of the deposits is dominated by these large boulders that weather out of the deposits and litter the upland surfaces. Most of the deposit, however, is composed of smaller wellrounded fragments of granitic rocks of Precambrian age, porphyritic andesite pebbles of Laramide age, and a few fragments of sandstones probably derived from the Dakota Sandstone and the Chugwater Formation. Most of the fragments of porphyry and granitic rock dug from the fresh exposures crumble easily in the hand, which suggests that the deposits have been thoroughly weathered. The deposits are poorly sorted and essentially unconsolidated, and they lack bedding. A photograph (fig. 20) of the deposits near Little Gravel Mountain shows the general character of the gravel.

Gravel deposits similar to those at Gravel Mountain occur at several places in the region. On a hill east of the quadrangle, in sec. 14, T. 1 N., R. 77 W., in the Granby quadrangle, gravel similar to that at Little Gravel Mountain contains, in addition to the granite and gneiss boulders, a few rounded boulders of basalt that may be related to Grouse Mountain Basalt of probable Pliocene age. Other deposits of gravel were seen by D. M. Kinney (oral commun., 1964) north of Porphyry Peaks along Blue Ridge in the Bowen Mountain quadrangle at ${ }^{*}$ altitudes near 11,500 feet. The gravel deposits are tentatively dated as Pliocene because they contain boulders of basalt that are of

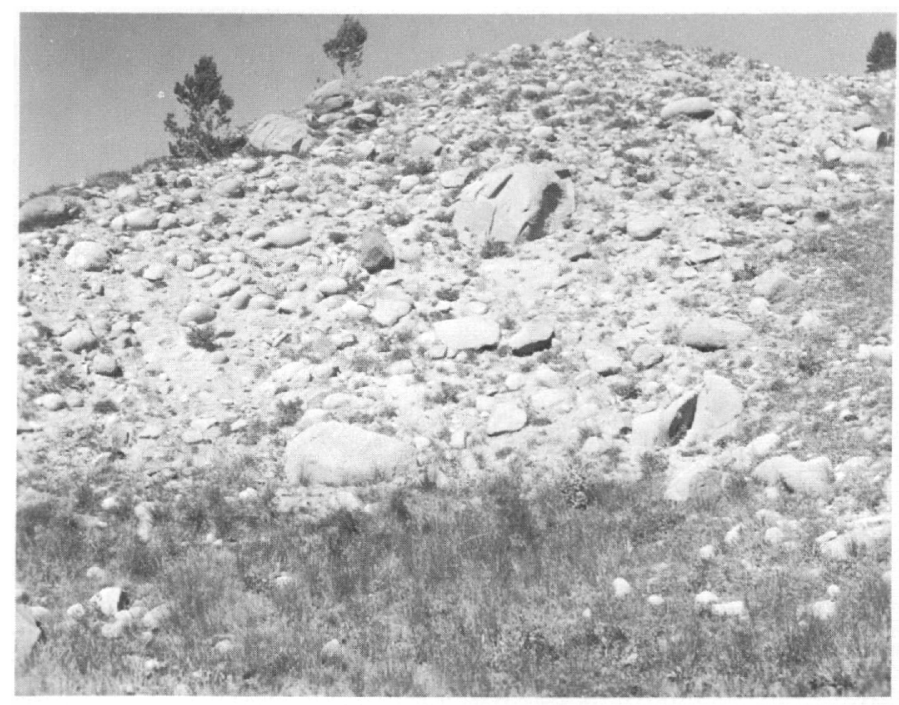

Figdre 20.-Boulder conglomerate capping the south ridge of Little Gravel Mountain. Large boulder near center is about 5 feet in diameter. 
probable Pliocene age and because they are probably older than Pleistocene age.

The deposits of Gravel Mountain may be genetically related to other boulder-bearing gravels scattered along the high country on the east side of the Front Range that Wahlstrom (1947) interpreted as till. The origin of these deposits is part of a large problem related to the late Cenozoic history of north-central Colorado, and the details of this problem await study. The deposits of Gravel Mountain may have been a part of a once more extensive mass of gravel deposited on a high-level pediment surface that was cut in late Tertiary time and that sloped away from the highest parts of the Front Range. This surface may correlate with the Rocky Mountain surface (Lee, 1917, p. 28), and the gravels that cover the surface may be related to late phases of the Ogallala Formation of late Tertiary age.

Van Tuyl and Lovering (1935, p. 1301) briefly mentioned that a remnant of a peneplain that they correlate with the Flat Top erosion surface occurs at Mount Bennay (now named Gravel Mountain and Little Gravel Mountain) just north of the mapped area. They stated, "These surfaces [Flat Top] truncate steeply tilted conglomerates of the Middle Park Formation, whose age is basal Eocene." Detailed study shows that the so-called Flat Top surface at Gravel Mountain actually truncates gravel deposits tentatively dated in this report as late Tertiary, and not Middle Park Formation. Thus, it seems certain that the surfaces, if any, at Gravel Mountain are much younger than the Flat Top erosion surface of Van Tuyl and Lovering.

\section{CONGLOMERATE AND MUDSTONE}

Surficial deposits of probable late Pliocene age extend from the Kremmling and Mount Powell quadrangles into the southwest corner of the Hot Sulphur Springs quadrangle, where the deposits cover two small flat-topped hills. The deposits are poorly exposed in the mapped area but are well exposed in sec. 32 , T. 1 N., R. $79 \mathrm{~W}$., in the Kremmling quadrangle. There, they are about 100 feet thick and consist of interbedded conglomerate, dark-reddish-brown and orangegray sandy mudstone, and coarse-grained sandstone that rest unconformably on the Troublesome Formation. A measured section in the center of sec. 32 is included below to show the general character of the unit. The conglomerate beds consist of well-rounded pebbles and cobbles of Precambrian granitic and metamorphic rocks in a sandy granulitic matrix. The conglomerates are poorly consolidated and appear similar in fabric and lithology to the Quaternary terrace deposits along the Colorado River.
The discovery of Pliocene deposits in the area was made by Peter Robinson (oral commun., 1965), who found fragmentary remains of a fossil beaver, identified by him as Dipoides (Univ. Colorado Mus. cat. No. 26761), in sec. 32, T. 1 N., R. 79 W. The fossil indicates a late Pliocene age, and a late Pliocene age supports the geomorphic relations in the area.

The deposits provide a significant clue to the antiquity of the Colorado River in the area, for they were probably deposited by streams tributary to the ancestral Colorado River in late Pliocene time. No evidence was found, however, to establish that the ancestral Colorado River was present in the area in Miocene time. Although these deposits are not widespread in Middle Park, they show by their unconformable relations with the Troublesome Formation and by their late Pliocene age that major uplift and erosion occurred in post-Miocene pre-middle Pliocene time.

Section of Pliocene deposits measured above Pheney lateral in center sec. $32, T .1$ N., R. 79 W., Kremmling quadrangle

Pliocene deposits:

Thickness

6. Sandstone, orange-brown, dirty, silty, clayey, poorly consolidated; contains interbedded conglomerate lenses a few feet thick; Dipoides, talpid, and Hypolagus found by Peter Robinson

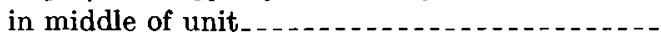

5. Gravel, poorly sorted and indurated; contains wellrounded smooth pebbles and cobbles as much as 9 in. long; matrix sandy -....................

4. Sandstone, brownish-gray, conglomeratic, dirty, poorly sorted and consolidated, even-bedded; pebbles are as much as $0.5 \mathrm{in}$. in diameter.....

3. Gravel, gray-brown; matrix silty and sandy; conglomeratic well-rounded pebbles as much as 2 in. in diameter are composed of Precambrian rocks; contains fossil bone scraps......--

2. Mudstone, orange-brown, poorly indurated; has sharp contact with unit 3

Total thickness of Pliocene deposits (rounded) .

Troublesome Formation (part):

1. Siltstone, orange-gray, clayey, sandy, granulitic, poorly exposed....

Partial thickness of Troublesome Formation. $\quad 20$

\section{QUATERNARY DEPOSITS}

TRAVERTINE

A travertine deposit about 100 feet in diameter and about 25 feet thick occurs along the ridge that connects Elk Mountain with Corral Peaks. The travertine is a brownish-gray banded rock that weathers to a gray rough surface. X-ray diffractograms of the rock show that it consists of at least 95 percent calcium carbonate. The deposit rests on the Middle Park Formation and is 
assigned a Quaternary age. The travertine accumulated around a spring that might be along an undetected fault in the Middle Park Formation.

\section{TERRACE DAPOSITS}

Remnants of terrace deposits of Quaternary age occur along most of the valleys of the larger streams and rivers in the area, but they are most extensive and complete along the Colorado River and the Williams Fork. These deposits are shown on the map (pl. 1), but they are not differentiated as to age or position owing to the difficulty in correlating the deposits. The terrace deposits are as much as 50 feet thick and consist mainly of coarse gravel that contains many wellrounded smooth boulders of Precambrian crystalline rocks about 2 feet in diameter and subordinate layers of sand, silt, and clay. At the west edge of the quadrangle, in sec. 9, T. 1 N., R. $79 \mathrm{~W}$., the terrace deposits contain large rounded biotite gneiss boulders about 6 feet in diameter enclosed in gravel matrix. Large boulders of biotite gneiss that probably were let down from older high-terrace deposits lie scattered along bedrock surfaces north of Cedar Ridge along the Colorado River valley. The boulders of biotite gneiss probably were derived from the large areas of biotite gneiss in the Williams Fork drainage.

The deposits occur in steplike levels along the valley sides and are as low as 15 feet and as high as 725 feet above the modern river flood plains. In general, deposits that are from 15 to 30 feet above the modern flood plains are probably of Recent age, and deposits that are from 50 to 725 feet above the modern flood plains are of Pleistocene age. Surfaces of some of the terrace deposits as seen on aerial photographs show speckled vegetation patterns similar to the "patterned ground" described by Malde (1961).

Terrace deposits along the Colorado River west of Byers Canyon occur at several levels above the river, but they are most extensive at about 80 feet above the river. These deposits are widespread and form broad sage-covered flats, which are locally cultivated. The Denver and Rio Grande Western Railroad and U.S. Highway 40 were built on the smooth gentle surface of these deposits for several miles along the Colorado River valley. The oldest terrace deposits mapped are along the Colorado and cap a hill in sec. 14, T. 1 N., R. $79 \mathrm{~W}$. The deposits are about 725 feet above the river. The youngest terrace deposits occur locally at the junction of the Colorado River and the Williams Fork and are about 15-20 feet above the modern flood plains. The terrace deposits along the Colorado River east of Byers Canyon are not as extensive as those west of the canyon. The deposits occur mainly at about $15,30,50$, 70 , and 250 feet above the river. Correlation among the terrace deposits east and west of Byers Canyon is uncertain because of the upsetting of gradients by the resistant crystalline Precambrian rocks in Byers Canyon.

A sequence of terrace deposits occurs east of Williams Fork Reservoir; the deposits, from youngest to oldest, are about 50, 190, 300, and 540 feet above the modern flood plain of the Williams Fork Reservoir. They consist of gravel and minor amounts of silt and sand. Deposits west of Williams Fork Reservoir that are mainly gravelly clay, silt, and sand might be remnants of an alluviated pediment surface; they were mapped and included with the terrace deposits. Correlation of terrace deposits of the Colorado River and the Williams Fork is uncertain.

Fossil soils that are locally preserved on the terrace deposits give some information about the relative ages of the deposits. Soils of Pleistocene age that by their degree of development probably indicate a preWisconsin age, using criteria of Scott (1963, p. 8), were seen at three localities. These soils are formed on coarse gravels about 190,300 , and 540 feet above the modern flood plain of the Williams Fork east of Williams Fork Reservoir. At each locality the soils have a fairly well developed dark-reddish-brown clay and iron-oxide enriched interval (B zone) about 1 foot thick and a calcium carbonate enriched interval $\left(\mathrm{C}_{c a}\right.$ zone) about 18 inches thick. The clay in the $\mathrm{B}$ zones forms good columns, is sticky, and makes a good ball when moistened in the hand. Younger soils characterized by thin poorly developed $\mathrm{B}$ zones but strong thick $\mathrm{C}_{\mathrm{ca}}$ zones were seen on terrace deposits that are from 50 to 80 feet above the flood plain of the Colorado River. The character of the soils and their height above the flood plain suggest that the soils are of Wisconsin age. Fossil soil profiles could not be found on the terrace deposits at 15-30 feet above the modern flood plains, but their nearness to the modern flood plain suggests that the deposits are of Recent age.

\section{LANDSIIDE AND TALUS DEPOSITS}

Landslide deposits were mapped at many places in the quadrangle (pl. 1). They vary from small isolated deposits several tens of feet in diameter to large composite deposits as much as several miles long that conceal underlying rocks. Most landslides formed in areas underlain by the Middle Park and Troublesome Formations and the Rabbit Ears Volcanics. These formations contain beds of soft tuffaceous rocks rich in clays that when saturated with percolating ground water are plastic and creep, flow, or slide to form earthflows or landslides. At a few places talus deposits were mapped, and they locally are mixed with or grade into landslide deposits.

Young landslide deposits are easily recognized in the field, identified on aerial photographs, and plotted 
on topographic maps by their typical physiographic form. Old landslides are harder to recognize, as their boundaries are not sharp, their surfaces are dissected, and their headwall scarps are obliterated. A good example of a large old landslide that formed primarily by earthflow of the Troublesome Formation can be seen along U.S. Highway 40 south of the Colorado River, mainly in sec. 20 , T. 1 N., R. $78 \mathrm{~W}$. During the Pleistocene, a terrace was cut on the landslide and alluviated by the Colorado River. South of Sunset Ranch, in secs. 11 and 14 , T. 1 N., R. 79 W., a young landslide deposit in the Troublesome Formation that shows sharp boundaries, a hummocky surface, and a steep headwall scarp can be seen from U.S. Highway 40. Another good example of a young landslide deposit is on the west side of Slide Mountain and involves the Middle Park Formation and the Rabbit Ears Volcanics. Small ponds are scattered on the surface of the deposit, and these ponds are typical of this and other young landslide deposits in the area.

\section{ALLUVIUM}

Alluvial deposits of Recent age are along most of the streams and rivers in the area, but only the thickest most continuous deposits are shown on the map (pl. 1). The deposits probably are nowhere more than 50 feet thick, and they consist of layers of poorly sorted clay, silt, sand, and gravel.

\section{HEAVY MINERALS}

The heavy-mineral assemblage of certain sandstone beds in the Mesozoic and Tertiary rocks was studied to gain information as to the source and the depositional history of the beds. Heavy minerals were separated from samples of the Morrison, Dakota, Benton, Middle Park, and Troublesome Formations with bromoform ( $\mathrm{sp}$ gr $>2.87$ ) from the very fine grained fraction $(<0.125>0.062 \mathrm{~mm})$ of screened samples. R. F. Gantnier and J. A. Thomas of the U.S. Geological Survey made the mineral separations and mounted the minerals in Aroclor $(n=1.66)$. Rough estimates of the amount of each species of nonopaque heavy minerals were made, and the results are shown in table 10.

The rocks of Mesozoic age (Morrison, Dakota, and Benton Formations) were deposited on the shelf adjacent to the Mesozoic miogeosyncline that lay to the west, and they rest above the beveled surface of the Front Range Highland (Lovering and Goddard, 1950, p. 57). The nonopaque heavy minerals from these rocks make up a small assemblage of chiefly well-rounded fairly stable minerals that are doubtless several cycles removed from their parent rocks. The source areas for the minerals are uncertain. Whereas the Mesozoic rocks are platform deposits that hardly reflect particular source areas, the Cenozoic rocks (Middle Park and
Troublesome Formations) are intermontane basin-fill deposits that strongly reflect the lithologic character of the source rocks in and peripheral to the Middle Park basin in Cenozoic time. The nonopaque heavy minerals from these rocks make up a fairly large assemblage of minerals, many of which are probably only short distances away from their parent rocks.

Samples from rocks of Mesozoic age contain a small assemblage of minerals that includes zircon, tourmaline, garnet, and rutile, listed in order of decreasing abundance. Other minerals that occur in trace amounts are epidote, hornblende, monazite, sphene, staurolite, and xenotime. White mica separated out with the heavy minerals from most samples but was not listed in table 10. Zircons are mostly colorless to pink rounded euhedral grains, some of which show overgrowths similar to those described by Young and Sims (1961, p. 283). Tourmaline grains are mainly well rounded and show a wide range of colors including greenish brown, brown, blue, bluish gray, and brownish pink. Garnets are equant and rounded and show chipped surfaces; some are crowded with inclusions. Samples from the Morrison Formation seem to contain a slightly different assemblage of minerals that occur in trace amounts than other samples of Mesozoic age. These minerals (hornblende, monazite, sphene, and xenotime) are known to occur in the metasedimentary gneisses of Precambrian age, and the minerals reflect the nearness of the Morrison to the underlying Precambrian rocks.

Table 10 shows samples of Middle Park Formation of Late Cretaceous(?) and Paleocene age arranged in approximate stratigraphic position, samples of youngest age being at the top of the table. The samples contain at least three genetic groups of nonopaque heavy minerals that seem to characterize three separate source-rock types. The first group includes small amounts of well-rounded zircon and tourmaline grains that probably came from reworking of Mesozoic sedimentary rocks in and adjacent to North-Middle Park basin in Middle Park time. The second group includes fairly large amounts of crystals, broken crystals, and cleavage fragments of allanite, epidote, garnet, and monazite, and a few grains of sillimanite and xenotime. Probably most of the minerals in this group were derived from the high-rank gneisses and granitic rocks of Precambrian age in and bounding the basin. Xenotime and monazite show rare-earth element absorption spectra in microscopic study that uses the techniques of Adams (1965). Allanite occurs in small amounts in nearly all samples of Middle Park Formation. X-ray analysis of the allanite was made by Fred Hildebrand (written commun., 1963) of the U.S. Geological Survey, and he reported that unheated grains show "good crystallinity and therefore [are] nonmetamict ***." 
TABLE 10.-Nonopaque heavy minerals from Mesozoic and Tertiary sedimentary rocks

[X, 70 percent of sample; C, 10-70 percent of sample; $R,<10$ percent of sample; VR, $<0.01$ percent of sample; U, occurrence uncertain]

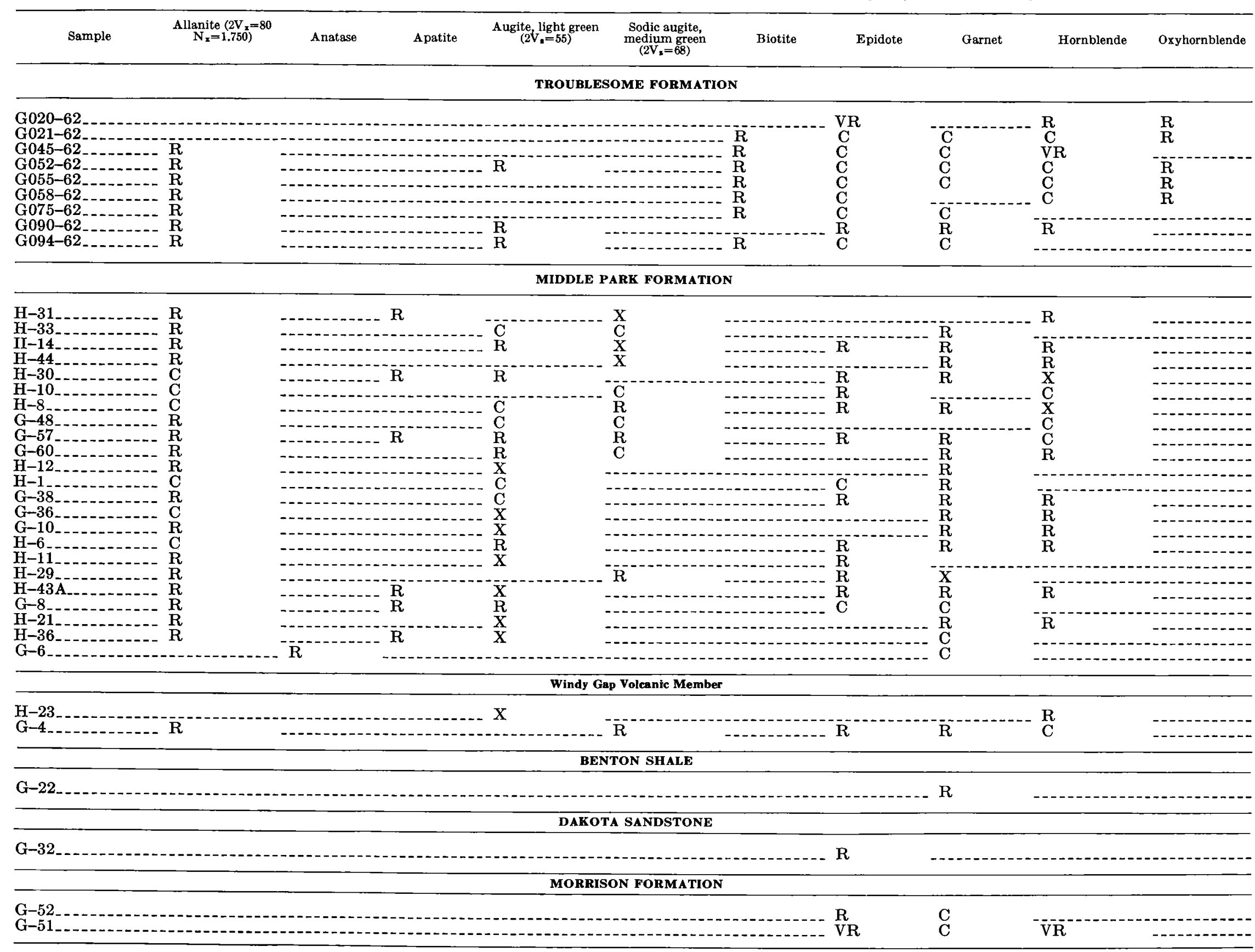


TABLE 10.-Nonopaque heavy minerals from Mesozoic and Tertiary sedimentary rocks-Continued

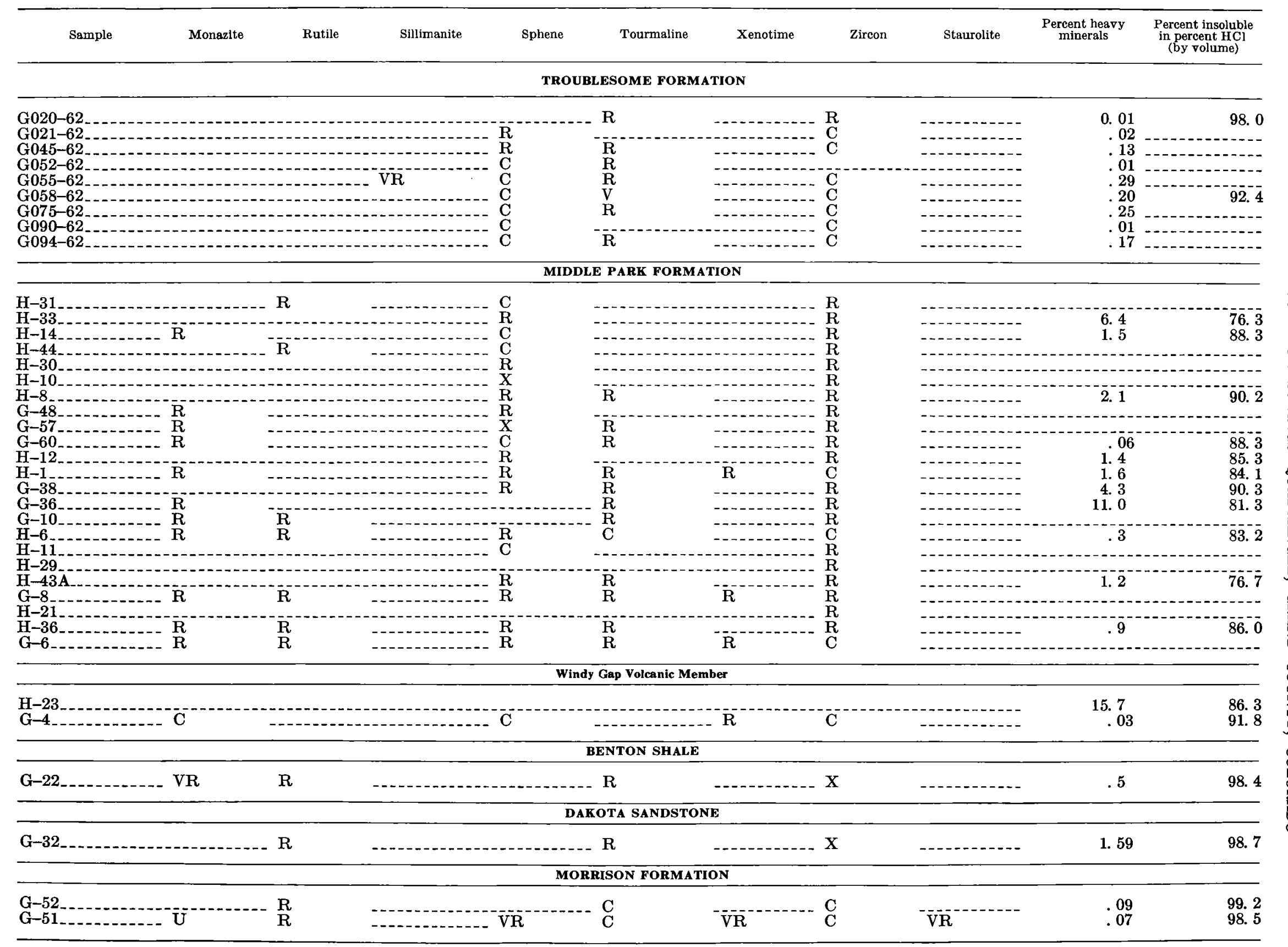


Biotite (not shown as present in the middle Park Formation in table 10, but a few grains are present) and sillimanite might be expected in larger amounts in the nonopaque heavy minerals because of their wide occurrence in the Precambrian rocks surrounding the basin. But the slender needles of sillimanite were probably broken during transportation into size ranges smaller than those used in this study $(0.062 \mathrm{~mm})$, and biotite occurs in fairly large flakes that would not appear in the size range studied. The third group of nonopaque heavy minerals contains a locally rich assemblage that probably was derived from the reworking of volcanic rocks along the east margin of Middle Park basin. The minerals are chiefly crystals, broken crystals, and cleavage fragments of very pale green diopsidic augite and medium-green sodic augite $\left(2 \mathrm{~V}_{\mathrm{z}}=67 ; \mathrm{N}_{\mathrm{y}}=1.710\right)$ and scattered grains of reddish-brown hornblende. Other nonopaque heary minerals, such as anatase, apatite, greenish-brown hornblende, rutile, sphene, and euhedral zircon, that occur in samples of Middle Park Formation may have originated in any of the three source rock types known to bound the North-Middle Park basin.

The nonopaque heavy minerals from samples of Troublesome Formation (Miocene) were inherited as would be expected from the preexisting rocks of Precambrian, Mesozoic, and early Tertiary age in and peripheral to the Troublesome Formation depositional basin. Epidote, garnet, hornblende, and sillimanite came either from the Precambrian rocks or from reworking of the Middle Park Formation. Small amounts of well-rounded tourmaline and zircon probably came from rocks of Mesozoic age. The chief source rocks for much of the tuffaceous Troublesome Formation in this area seem to have been acid to intermediate volcanic-derived material that must have mantled parts of the uplands surrounding the Troublesome basin. Minerals that are known to occur in the Rabbit Ears Volcanics, such as oxyhornblende and biotite, are only rarely seen in the assemblage of heavy minerals from the Troublesome. Perhaps the oxyhornblende is destroyed easily during transportation, and biotite occurs only sparingly in the size range used. Size ranges larger than those studied contain considerably more biotite. Trace amounts of hypersthene, iron-rich olivine, and cherkinite were found in a few samples of ash from the Troublesome Formation in the Kremmling quadrangle, but they are not listed in table 10 .

Although the nonopaque heavy-mineral assemblages from samples of Middle Park and Troublesome Formations are similar, two differences that locally can be used to separate the assemblages are the lack of large amounts of cleavage fragments of light-green diopsidic augite or medium-green sodic augite in the Troublesome
Formation, and the remarkably large amount of total heavy minerals in samples of Middle Park Formation. Most of the total heary minerals in Middle Park samples are magnetite; the rest are nonopaque.

\section{STRUCTURE \\ REGIONAL SETTING}

The Hot Sulphur Springs quadrangle is in the southern part of a large northward-trending open syncline, North-Middle Park basin, which is one of the larger structural units in north-central Colorado. The syncline is more than 70 miles long and about 40 miles wide and extends south from near the ColoradoWyoming border to south of the 40th parallel. Although the syncline is a structural unit, physiographically it is divided into two topographic basins, Middle Park and North Park, separated by the eastward-trending Rabbit Ears Range. In general, the syncline consists of Mesozoic and lower Tertiary sedimentary rocks between two broad northward-trending anticlinal uplifts cored with Precambrian crystalline rocks-the Front Range to the east and the Park Range to the west. Basin-margin thrust faults including the Stillwater and Independence Mountain thrusts complicate the simple regional pattern of syncline and adjacent anticlines. Another group of thrust and associated faults, including the Vasquez and Williams Range thrusts, breaks the southern part of the syncline into small structural blocks. The Hot Sulphur Springs quadrangle lies in this area. A brief description of the regional structural framework of North-Middle Park basin has been given by Tweto (1957).

In much of the northern part of the quadrangle the structure of the exposed rocks is fairly simple and consists of a thick sequence of gently folded Tertiary sedimentary rocks of the Middle Park Formation. In the southern part of the quadrangle the structure is more complex; several west-northwest-trending faults of large displacement expose a thin sequence of northeast-dipping Mesozoic sedimentary rocks in fault-block pattern beneath a thin cover of Tertiary sedimentary rocks and Quaternary alluvial sediments. The general structure of the rocks in the quadrangle and their structural relation to rocks in surrounding areas are shown in figure 21. Several cross sections are shown on plate 1 ; they give structural interpretations of the rocks at depth in the quadrangle.

The rocks in the area show effects of several periods of tectonism. The Precambrian metasedimentary rocks in the area show evidence of at least two stages of major tectonism, but the great age of the rocks, the fact that the rocks locally were repeatedly deformed in post-Precambrian time, and the small outcrop area of the rocks relative to larger outcrops in surrounding 


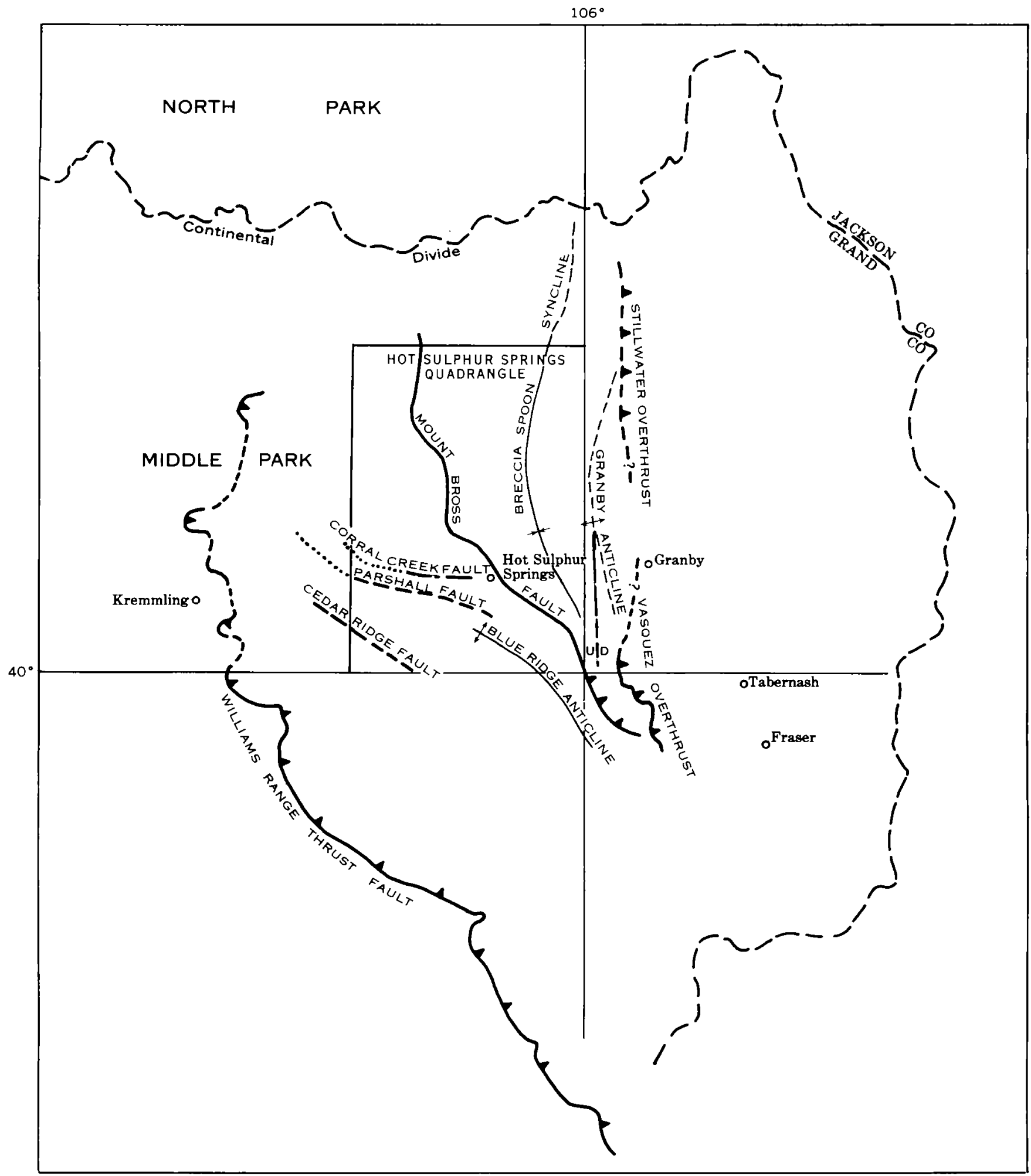

Figdre 21.-Generalized structure map of the Hot Sulphur Springs quadrangle and surrounding areas. Modified from Tweto (1957, p. 19). 
areas preclude all but a few brief generalizations concerning Precambrian tectonism. These are presented in a preceding section of the report.

Mesozoic and Tertiary rocks in the area record two stages of Laramide tectonism and one stage of postLaramide tectonism. Laramide time as used here comprises the interval from latest Cretaceous through Eocene time. The sequence of tectonic events in the mapped area is in general similar to the sequence established by the work of many geologists in other parts of north-central Colorado and summarized by Lovering and Goddard (1950, p. 58). Effects of the Laramide tectonism in the mapped area are masked in many places by middle and upper Tertiary basin-fill deposits and Quaternary alluvial deposits; nevertheless, enough details of the Laramide tectonism are known to establish the following tectonic events.

An early stage of Laramide tectonism of probable latest Cretaceous age occurred before deposition of the Middle Park Formation of Late Cretaceous(?) and early Tertiary age and in general consisted of (1) general uplift of the Front and Park Ranges accompanied by erosion of the Paleozoic and Mesozoic sedimentary rocks from the ranges and from certain areas in Middle Park, and (2) formation of the North-Middle Park syncline. Structure in the Mesozoic rocks in the area formed by the early stage of Laramide tectonism includes largescale west-northwest-trending faults, such as the Corral Creek and Parshall faults, and folds, which are indicated by an unconformable relation between the Middle Park Formation and the older rocks near Hot Sulphur Springs (fig. 9). Large amounts of porphyritic andesitic igneous rocks derived chiefly from volcanic and hypabyssal intrusive centers in Middle Park occur in the lower part of the Middle Park Formation and attest to volcanism during early Laramide time. The time relationship between plutonism, volcanism, and uplift of the Front and Park Ranges is uncertain.

A later stage of Laramide tectonism of probable late Eocene age is recorded by large open folds in the Middle Park Formation and by large-scale north- to northwest-trending reverse faults that cut the Middle Park Formation. Faults that are related to this stage of Laramide tectonism in the general area of the Hot Sulphur Springs quadrangle include the Williams Range and Vasquez thrust faults and the Mount Bross fault. Faults and folds associated with the second stage of Laramide tectonism may have had an early Laramide ancestry, and some field evidence indicates that many of the Laramide faults were active throughout Laramide time.

Evidence for a period of post-Laramide tectonism in the quadrangle is equivocal, but elsewhere in the region good evidence for post-Laramide tectonism was found.
The youngest faults in the mapped area are three small faults on the north and west flanks of Slide Mountain that are inferred to cut the Rabbit Ears Volcanics and the Grouse Mountain Basalt. Outside the mapped area, in the central part of the Kremmling quadrangle, the Troublesome Formation is steeply folded adjacent to faults of a north-trending fault system. At one place the Troublesome is downfaulted at least several hundred feet against the Pierre Shale. North of Granby, in the Trail Mountain quadrangle, basalts that rest on Miocene beds that correlate with the Troublesome Formation are probably step-faulted. To the north in North Park, post-Miocene tectonism has been demonstrated by many geologists including Hail (1965, p. 117) and Montagne and Barnes (1957); there, the North Park Formation is sharply folded in the North Park syncline and faulted in Cunningham and Big Creek Parks. To the northwest of the mapped area, near Steamboat Springs, Colo., Miocene rocks are faulted, and, according to G. L. Snyder (oral commun., 1966), at least 1,500 feet of post-Miocene movement can be proved. In summary, abundant proof of postMiocene tectonism occurs in the region. The peak of the movement was probably in early Pliocene time, concurrent with the deposition of the gravels of the upper part of the Ogallala Formation of the Great Plains.

\section{FAULTS}

West-northwest-trending faults with large displacements occur in the southwestern part of the quadrangle, and they mark an early stage of Laramide tectonism in the area. The faults produced northward-dipping Mesozoic rocks in fault-block pattern exposed in windows in the Tertiary rocks and Quaternary deposits. Rocks north of the faults are upthrown, and the dips of the fault planes range from gentle to steep. One of these faults, the Parshall fault, is concealed for most of its length, but its subsurface presence is well established by the spatial relation of rock units shown on plate 1 . About 1 mile west of Parshall, Colo., northward-dipping Niobrara Formation on the downthrown side of the Parshall fault is nearly in juxtaposition with the Precambrian crystalline rocks of the upthrown side, but the trace of the fault that separates these rocks is covered by Quaternary alluvial deposits or by the Middle Park Formation. Farther to the west, map relations clearly indicate that the Pierre Shale is in fault contact with the Precambrian rocks under cover of the Middle Park Formation. The Parshall fault is probably a fault zone several hundred feet wide, as indicated by outcrops of sheared and altered Precambrian quartz monzonite parallel to the fault in railroad cuts along the Denver and Rio Grande Western Railroad track west of Parshall. The attitude of the fault plane is not 
known, but the rectilinear trace indicates that it probably is a high-angle fault. The amount of throw on the fault must be in excess of 1,000 feet. The post-Pierre Shale pre-Middle Park Formation age of the faulting seems certain, for beds in the lower part of the Middle Park Formation in sec. 3, T. 1 N., R. 79 W., that lie along the trace of the fault appear undisturbed and in apparent structural continuity with other Middle Park beds to the north. Recurrent movement along the fault in Middle Park time or in post-Middle Park time is indicated by small faults and upturned beds of the Middle Park at the west end of Byers Canyon, north of Parshall, and in sec. 15, T. 1 N., R. 78 W. The extension of the fault to the east is problematical; it may extend under the Middle Park Formation, separate Mesozoic sedimentary rocks from Precambrian rocks, and join the Mount Bross fault, which may have had a pre-Middle Park Formation ancestry. West of the quadrangle, field relations in the Kremmling quadrangle suggest that the Parshall fault is present near Sulphur Springs, but the exact position of the fault awaits completion of mapping currently in progress.

Another fault of probable early Laramide age, the Corral Creek fault, is well exposed in the Corral Creek valley; there, granite of Precambrian age is thrust onto the Dakota Sandstone (fig. 22). In the Corral Creek valley the fault plane dips about $30^{\circ}$ NNE. and appears to be in incompetent beds in the transition interval between the Dakota and the Benton. The fault can be traced with confidence to a point about 1 mile northwest of Corral Creek, but farther west the fault is covered by the Troublesome Formation. East of Corral Creek, where the fault is locally covered by the Rabbit Ears Volcanics or by the Grouse Mountain Basalt, the fault cuts across the Dakota, and the Precambrian rocks are against the Morrison Forma-

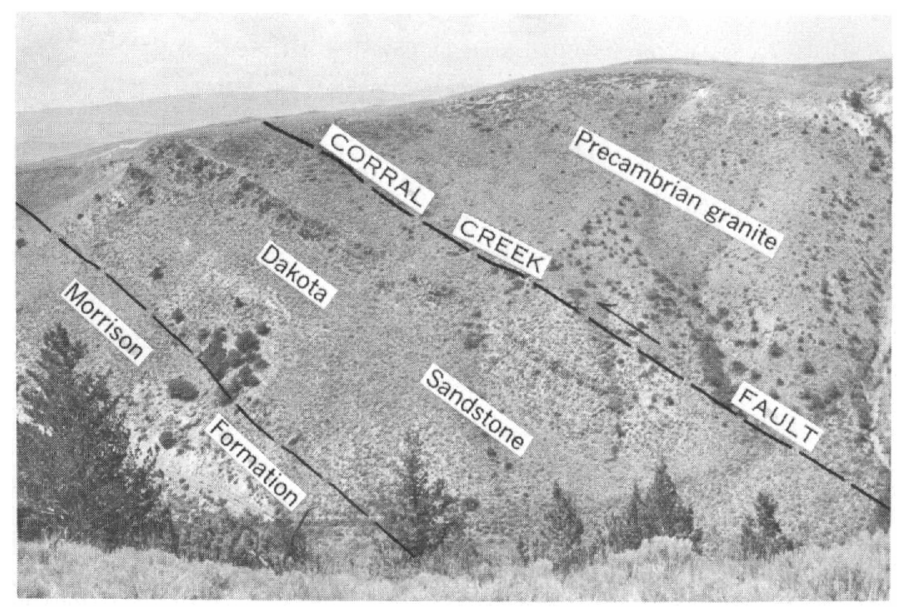

FigURe 22.-View looking west at the Corral Creek fault along the lower reaches of Corral Creek. Granite of Precambrian age is thrust onto Dakota Sandstone. Fault dips about $30^{\circ} \mathrm{N}$. tion. The fault is inferred to extend into sec. 9, T. 1 N., R. $78 \mathrm{~W}$., on the basis of a few isolated exposures of sheared quartz monzonite locally stained with secondary copper minerals. The eastern extent of the fault and its relation to the Mount Bross fault are uncertain. The amount of displacement on the fault is not known, but it probably is in excess of 500 feet and may be considerably more. The fault is probably of early Laramide age because it cuts rocks of Cretaceous age, probably is covered by the Middle Park Formation, is covered by rocks of Oligocene age (lower part, Rabbit Ears Volcanics) in the $\mathrm{SW} / 4$ sec. 6, T. 1 N., R. 78 W., and is similar in trend to the Parshall fault of early Laramide age.

Other faults that are probably related to the system of west-northwest-trending faults of early Laramide age include two faults in Precambrian granite north of the Corral Creek fault. One of these faults can be traced a short distance away from the canyon of Corral Creek as a zone of sheared granite that dips gently to the north. The amount of displacement on the fault is not known. Another fault is inferred to cut biotite gneiss along Cedar Ridge because of a prominent lineation on aerial photographs. The Cedar Ridge fault, a fault of west-northwest trend that puts biotite gneiss on the north in fault contact with the Morrison Formation on the south, is exposed just west of the quadrangle along Reeder Creek near the section line between secs. 17 and $20, T .1 \mathrm{~N}$., R. $79 \mathrm{~W}$. This fault may have a large displacement, but. the attitude of the fault plane and the amount of displacement are not known. The fault is inferred to extend into the Hot Sulphur Springs quadrangle under cover of the Troublesome Formation and the Quaternary alluvial deposits.

Faults that cut the Middle Park Formation and older rocks and that date a late stage of Laramide tectonism include the Mount Bross fault and a few smaller related faults. The Mount Bross fault is the most extensive fault in the mapped area, and it can be traced for about 20 miles from the southeast corner to the north border of the quadrangle. The fault takes its name from the excellent exposures of the fault on the east side of Mount Bross (fig. 23), where it was first recognized by G. L. Cannon, Jr., in 1889 and reported by Cross (1892). The fault extends several miles southeastward from the quadrangle into the Bottle Pass quadrangle, where it has been mapped by Ogden Tweto and R. B. Taylor of the U.S. Geological Survey. According to Tweto $(1945,1947,1957)$, it is the westernmost fault of a zone of faulting in the Bottle Pass quadrangle that he named the Vasquez overthrust (Tweto, 1957).

South of Elk Mountain, the Mount Bross fault brings the Pierre Shale against the conglomeratic sandstone 


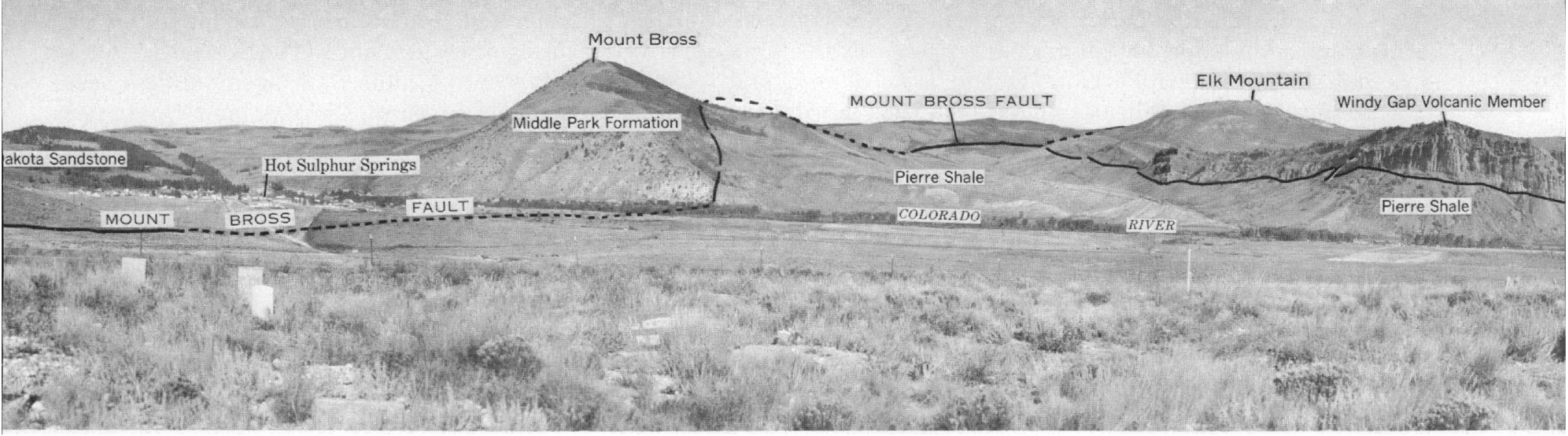

FIgure 23.-View looking north at Mount Bross fault from Hot Sulphur Springs Cemetery. Pierre Shale is in fault contact with Middle Park Formation.

and grit of the Middle Park Formation. Although the general trace of the fault can be determined with confidence, precise location of the fault is difficult because the area is locally heavily timbered. North of Elk Mountain the fault is in the Middle Park Formation, and lack of marker beds and presence of thick stands of evergreens make placement of the fault difficult. The exact attitude of the fault plane could not be determined in the field, but the rectilinear character of the fault trace as it crosses fairly rugged topography suggests that it is a high-angle reverse fault and that the fault plane dips steeply north or northeast, perhaps near $70^{\circ}-80^{\circ}$. Other evidence that suggests that the fault is a high-angle reverse fault is the association of tight overturned synclines on the downthrown side of the fault. These synclines probably formed as the hanging wall of the fault overrode the footwall. As no folding was seen in the footwall rocks from Cottonwood Pass to sec. 33, T. 2 N., R. 78 W., the fault plane may be nearly vertical. Cannon (in Cross, 1892, p. 207) determined that the fault plane is exposed "at the southeastern base of the mountain [Mount Bross] where there is a polished plane with a W.N.W. strike, and a dip $70^{\circ}$ N.N.E." The writer could not find the surface described by Cross, but it may be covered or may have been destroyed by erosion.

The throw of the Mount Bross fault probably decreases from south to north. In the southern part of the mapped area the fault separates Pierre Shale on the east from Middle Park Formation on the west, and the throw on the fault is probably between 1,000 and 2,000 feet. Near Hot Sulphur Springs the throw may be about 1,000 feet, but estimates of the throw are based on bedding attitudes in soft Cretaceous shales. The shale may have been disharmonically folded, and, accordingly, the displacement may be variable. In the northern part of the area the fault separates Middle Park Formation sandstones and conglomerates, and the throw may be less than 1,000 feet. North of the area the Mount Bross fault passes into an asymmetric anticline.

Mention should be made of a puzzling structural relation east of Hot Sulphur Springs and west of the Mount Bross fault. In this area the strike of the Niobrara is such that it would seemingly place Niobrara in fault contact with the Pierre on the east side of the fault. The stratigraphic relation of the younger formation to the east and the older to the west with the apparent relative movement down on the east block is in direct conflict with the actual relative movement on the fault-up on the east. Perhaps either pre-Middle Park Formation folds or faults or undetected postMiddle Park folds or faults are responsible for the structural anomaly. Another possibility is that the dip of the Mount Bross fault flattens at depth and parallels the contact between the Pierre and the Niobrara. Thus, the Pierre could be brought from the east along the fault, and this would explain the anomalous stratigraphic-fault relation.

An unusual feature of the fault is its lobate trace from sec. 33 to sec. 6 , T. 2 N., R. 78 W. The lobe might have formed by later folding of the fault plane on a northeast axis, but evidence to support this conclusion is equivocal.

North of Grouse Mountain a zone of northwardtrending steeply dipping to overturned beds about half a mile wide in the Middle Park Formation (pl. 1) lies just west of the Mount Bross fault. The zone is 
easily identified on aerial photographs as a northwardtrending lineation in the growth patterns of the trees and shrubs. Along Paradise Gulch, Ethel Creek, and the north fork of Wheatley Creek the beds in the zone east of the Mount Bross fault dip generally east or northeast into the Breccia Spoon syncline. West of the fault the beds are mainly steep or overturned. The structure as outlined by the dips and the trace of the Mount Bross fault is a large asymmetric faulted anticline. Austin (1957) and Shearer (1957) applied the name Corral Peaks anticline to this structure.

Because the Mount Bross fault cuts the Middle Park Formation of Late Cretaceous(?) and Paleocene age and is seemingly covered by the Rabbit Ears Volcanics of Oligocene and Miocene(?) age, the major movement on the fault probably occurred in the Eocene, during a late stage of Laramide movement. Pre-Middle Park Formation movement on the fault is suggested by porphyritic augite syenite dikes of probable Cretaceous age whose distribution and trends parallel the fault. The dikes cut the Pierre Shale on the upthrown side of the Mount Bross fault; the dikes, as has been suggested previously (Izett and others, 1963), were probably sources for some of the volcanic debris in the base of the Middle Park Formation.

Several small faults that may be related to the late stage of Laramide movement occur in sedimentary rocks at the east end of Byers Canyon, and one of these faults is shown on plate 1. The large fault separates downthrown Middle Park Formation on the west from upthrown Morrison Formation on the east. The springs from which the town of Hot Sulphur Springs takes its name seemingly issue from this fault.

Several faults cut the Precambrian rocks in Byers Canyon, and many other zones of sheared rocks suggest faults, but they could not be traced for any great length and are not shown on the map.

\section{FOLDS}

Most of the folds in the area are broad north- to northwest-trending folds, but a few are tight and overturned north- to northwest- and northeast-trending synclines associated with the Mount Bross fault. A small uplifted area that formed during the early Laramide tectonism is west and southeast of Hot Sulphur Springs, and there the Middle Park Formation truncates the Mesozoic rocks and laps onto the Precambrian crystalline rocks. Marvine (1874, p. 167) referred to this uplift as the Hot Springs fold and said of the fold: "These facts clearly show that here was a local folding of the rocks which occurred before the lignitic formation [Middle Park Formation] commenced to be laid down, and probably close upon the completion of the deposits of the friable and concretionary sandstones which have been designated as No. 5 [Pierre Shale]." Other areas of uplift of pre-Middle Park age doubtless occur in the area under cover of Tertiary and Quaternary rocks. Folds in the area that formed during the late Laramide tectonism are described below.

The Breccia Spoon syncline is the largest fold in the area, and its approximate trough line, which roughly trends north, is shown on plate 1 . The syncline occupies much of the eastern part of the quadrangle and extends northward from near Cottonwood Pass for several miles north of the quadrangle boundary. The configuration of the fold in cross section is especially well shown along the Colorado River valley from just east of Hot Sulphur Springs to Windy Gap. Resistant units in the Middle Park Formation such as the Windy Gap Member, the breccia of Marietta Creek, and other sandstone and grit beds form ledges and cliffs separated by soft, slope-forming mudstone units. The ledges and cliffs occur in remarkable terracelike steps that rise above the valley floor of the Colorado River. A photograph of part of the syncline showing the "terraces" and continuous ridges outlining the fold is shown in figure 7 . Marvine (1874) named the fold the "breccia spoon" in reference to its spoon shape and because the fold is especially well outlined by the ridge-forming breccia beds in the Windy Gap Member.

The Breccia Spoon syncline is markedly asymmetric; the west limb of the fold is gentle and is characterized by northeast dips of $20^{\circ}-30^{\circ}$, but the east limb is steep and is characterized by west dips of $50^{\circ}-70^{\circ}$. The outcrop pattern of the Middle Park Formation and bedding attitudes clearly show that the syncline plunges northward about $6^{\circ}$. The west limb of the fold is bounded by the Mount Bross fault, and the east limb of the fold is the same as the west limb of the Granby anticline (Lovering, 1930; Sanders, 1957). The axial zone of the Granby anticline lies east of the quadrangle, and a brief reconnaissance along this zone indicates that it is a complex structural zone that probably contains both reverse and large normal faults. In general, the trends of the Mount Bross fault and the Granby anticline converge in an area just southeast of the quadrangle boundary along Eightmile Creek, and the Breccia Spoon syncline seems to have formed in response to uplift along the Mount Bross fault and faults along the trend of the Granby anticline. In general, the Breccia Spoon syncline represents a fairly gently deformed block between two large faulted anticlines.

Several northwest-trending folds occur west of the Mount Bross fault in the southeastern part of the quadrangle. The folds are formed in coarse sandstones and grits of the Middle Park Formation in an area 
where the Middle Park truncates underlying Mesozoic sedimentary rocks. Because these folds are formed in an area where the Middle Park truncates underlying deformed Mesozoic rocks and because the Middle Park rests on an erosion surface of considerable relief, estimates of the closure and the pre-Middle Park structural relations are not reliable. The largest of these folds was named the Blue Ridge anticline by Tweto (1957, p. 19) ; it extends from the quadrangle southward for several miles. The anticline is a broad open northwest-trending fold whose limbs dip less than $10^{\circ}$. The crest line of the fold is poorly defined, but it probably lies along Beaver Creek.

Tight synclines formed in the Middle Park Formation just west of the trace of the Mount Bross fault in three areas in the quadrangle. The traces of the axial planes of the folds are shown on plate 1 , but they are located only approximately, owing to difficulty in getting reliable bedding attitudes and to lack of marker beds in the coarsely conglomeratic sandstones in the formation. Two of the synclines, one in the southeast corner of the quadrangle and the other west of Corral Peaks, are overturned, and their axial planes dip steeply northeast and east-southeast, respectively. The west limbs of these folds are gentle and dip about $10^{\circ}$, but the east limbs are steep and are locally overturned. The axial trends of the synclines parallel the trend of the Mount Bross fault, and a genetic relation between the folds and the faults seems certain. The folds formed on the downthrown side of the Mount Bross fault and represent the locally overturned limb of a large anticlinal fold along the Mount Bross fault.

Gentle folds in the Middle Park Formation occur at several places in the area, especially in the northwestern

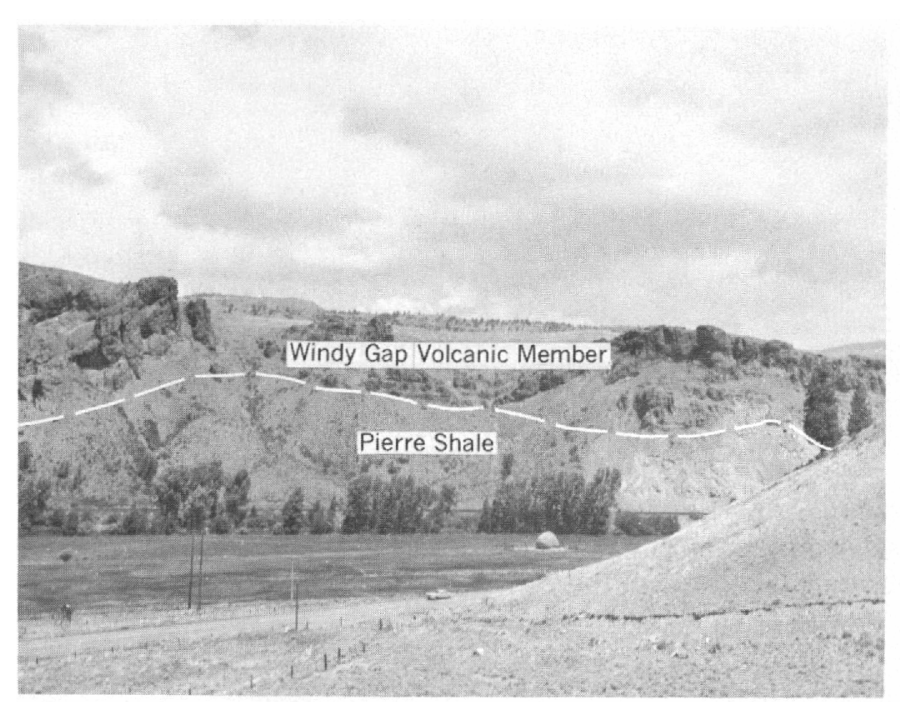

Figure 24.-Small-scale folds in the Windy Gap Member of the Middle Park Formation along the Colorado River east of Hot Sulphur Springs. part of the quadrangle, but their exact configuration is not accurately known. Reliable bedding attitudes that would better delineate these folds in the gently dipping coarse grits of the Middle Park Formation are hard to find.

Small-scale open folds in the Windy Gap Member are present along lower Ute Bill Creek and Gardiner Creek; they are shown in figure 24. These folds occur only in the Windy Gap and are not present in the underlying or overlying beds. The folds may have formed by mudflow or differential compaction during the deposition of the Windy Gap.

A syncline probably occurs in the Pierre Shale in the southeast corner of the mapped area, but lack of reliable bedding attitudes in the soft shales and complication due to the intrusion of the syenite dikes in the area preclude defining a trough line.

\section{JOINTS}

About 1,300 joints were measured in Precambrian metasedimentary and granitic rocks and Mesozoic and lower Tertiary sedimentary rocks in the mapped area, and the poles to these joint surfaces were plotted on the lower hemisphere of a Schmidt equal-area net. The plots of the joints were contoured using the method described by Billings (1942), and the contour diagrams are shown in figure 25 . The joints are not shown on plate 1, but they are shown on preliminary maps of the Hot Sulphur Springs area (Izett and Hoover, 1963; Izett and Barclay, 1964).

Joints in quartz monzonite of Precambrian age were measured in Byers Canyon, and there the strongest set of joints is nearly vertical and strikes about north. This set of joints is shown on figure $25 \mathrm{~A}$ by a strong maximum at $\mathrm{N} .5^{\circ} \mathrm{E}$. Other joint sets are represented by maximums at N. $5^{\circ} \mathrm{W} ., 60^{\circ} \mathrm{W}$; N. $35^{\circ} \mathrm{W}$., vertical; N. $35^{\circ}$ E., $20^{\circ}-50^{\circ} \mathrm{NW}$.; N. $80^{\circ}$ W., vertical; and N. $45^{\circ} \mathrm{W}$., vertical. Joints in biotite gneiss of Precambrian age were measured along Cedar Ridge and in the canyon of the Williams Fork below Williams Fork Reservoir. The strongest set of joints is vertical and strikes about north; this set is shown in figure $25 B$ by a strong maximum at about N. $12^{\circ} \mathrm{E}$. Other joint sets are shown by maximums at $\mathrm{N} .70^{\circ} \mathrm{W}$., vertical, and $\mathrm{N}$. $65^{\circ} \mathrm{W} ., 35^{\circ} \mathrm{SW}$.

Joints in sandstone and siltstones of Mesozoic age were measured on the north side of Cedar Ridge and at Hot Sulphur Springs. The strongest joints form a conjugate set that is shown in figure $25 \mathrm{C}$ by maximums at N. $35^{\circ}$ E., vertical, and N. $55^{\circ}$ W., $65^{\circ} \mathrm{SW}$. Another maximum occurs at N. $34^{\circ} \mathrm{W} ., 60^{\circ} \mathrm{SW}$. A third set of joints is defined by a maximum near N. $10^{\circ} \mathrm{W} ., 70^{\circ} \mathrm{W}$.

Joints in sandstones in the Middle Park Formation of Late Cretaceous (?) and early Tertiary age form a conjugate 

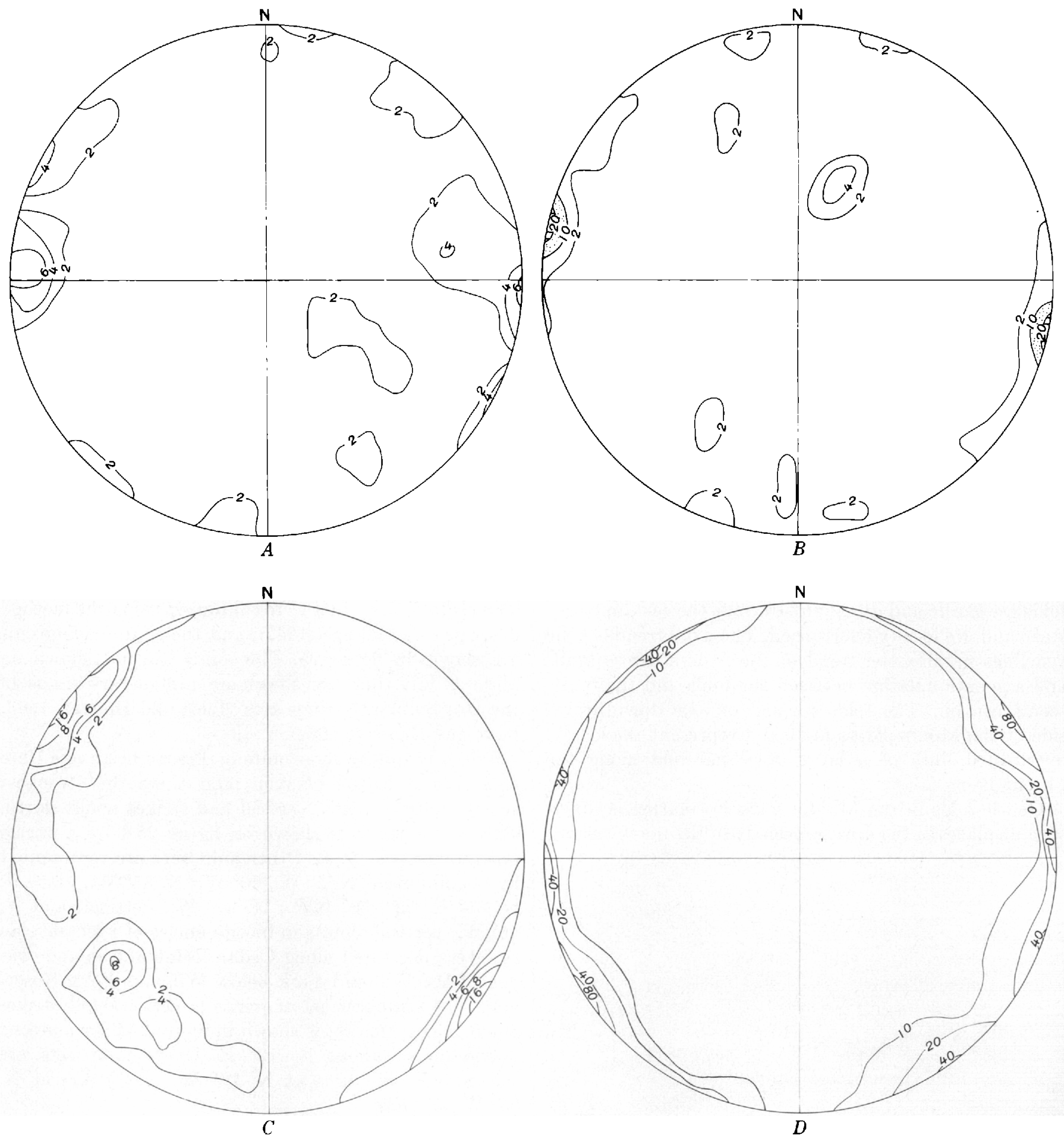

Figure 25.-Contour diagrams of joints. A, In quartz monzonite of Precambrian age in Byers Canyon; lower hemisphere plot of 216 poles. $B$, In biotite gneiss of Precambrian age; lower hemisphere plot of 200 poles. $C$, In sedimentary rocks of Mesozoic age; lower hemisphere plot of 299 poles. D, In Middle Park Formation; lower hemisphere plot of 694 poles. 
set that strikes about N. $35^{\circ} \mathrm{W}$. and N. $65^{\circ} \mathrm{E}$. and are nearly vertical (fig. $25 D$ ). Two other sets of vertical joints are shown in figure $25 \mathrm{D}$ by maximums at $\mathrm{N} .5^{\circ}$ W. and N. $18^{\circ}$ E. Although most of the joints in the Middle Park Formation are nearly vertical, some nearly flat joints were measured along the east limb of the Breccia Spoon syncline where the Middle Park dips steeply to the west; but only a small number of these joints were measured, and they do not show in figure $25 D$. Some joint surfaces are coated with a thin veneer of calcite or zeolite.

Analysis of joint data with the hope of relating certain joint sets to particular stress patterns associated with the formation of the large structures in the area meets with serious difficulties. These difficulties that complicate any analysis made include: a change in trend of joints with change in rock type, curving and irregularity of some joint surfaces, interpretation of as many as nine sets of joints on one small outcrop of Tertiary rocks, and repeated deformation that may affect the orientation of earlier joint sets. De Sitter (1956, p. 133-134) summarized the difficulties that he and others met during joint studies in other areas. Despite these difficulties, a few generalizations seem warranted. A generally north trending set of joints occurs in Precambrian rock units, and they may be longitudinal joints associated with the uplift of the Front Range, whose long axis trends north. In Mesozoic rocks a set of joints trends about $\mathrm{N} .35^{\circ}-55^{\circ} \mathrm{W}$. and parallels the strike of the Mesozoic rocks in the southern part of the quadrangle. These joints dip an amount that is nearly complementary to the dip of the beds, and they could have formed either before the beds were tilted and later rotated or while the beds were being tilted. Joints that trend about N. $35^{\circ} \mathrm{E}$. are generally nearly vertical and straight and form a conjugate set with the $\mathrm{N} .55^{\circ} \mathrm{W}$. joints. Where the Middle Park Formation is folded, one set of joints usually can be found that parallels the strike of the beds and, like the joints in the Mesozoic rocks, dips an amount that is complementary to the dip of the beds. Another set of joints commonly is oriented at about $90^{\circ}$ and forms a conjugate set. Where the beds are nearly horizontal the joint pattern seems irregular. Where faults occur, joints that clearly seem related to the faults are dominant and complicate the earlier formed joint pattern.

\section{GEOLOGIC HISTORY}

The general aspects of the geologic history of the region which includes the Hot Sulphur Springs quadrangle have been known for many years. Knowledge of certain geologic details pertinent to this history that was gained during geologic study of the quadrangle can be added to the general framework.
During Precambrian time a sequence of somewhat pelitic sedimentary rocks was deposited on yet to be recognized older basement rocks. These sedimentary rocks were regionally metamorphosed into a sequence of high-rank biotite gneisses of the sillimanite-almandine facies and later retrograded. Tectonism of at least two periods deformed the rocks into the older, tight northwest-southeast folds and the younger, northeastsouthwest folds. The gneisses were invaded by plutons of granodiorite, quartz monzonite, granite, and biotitequartz diorite. The temporal relation among the tectonism, plutonism, and metamorphism in the quadrangle has not been clearly established, but scant data suggest that plutons of Boulder Creek Granodiorite were emplaced during the regional metamorphism and deformation. Information from similar rocks in the Front Range indicates that granodiorite there was emplaced during "the regional plastic deformation" (Sims and Gable, 1964, p. 42). Large amounts of these crystalline Precambrian rocks were probably removed during a long period of erosion before the beginning of Paleozoic time, and the area was probably beveled almost to a plain.

No Paleozoic rocks occur in the mapped area, and details of this period of the geologic history can only be inferred from geologic data available in surrounding areas. A thin sequence of Paleozoic rocks probably covered the area of the quadrangle, but the rocks were removed during the uplift of the ancestral Rockies in late Paleozoic time. The mapped area lies within the boundaries of this uplifted area, generally called the Front Range Highland.

During Mesozoic time a Late Jurassic sea spread southward into the region, but because of either nondeposition or later removal, no rocks associated with this marine invasion occur in the area. In nearby areas a thin sequence of marine sedimentary rocks deposited in the Jurassic sea can be found north of Kremmling and at Tabernash Campground. After the Late Jurassic sea retreated the area was covered with claystones, limestones, and sandstones of the Morrison Formation that were apparently deposited in low-lying lakes and streams. Continued continental sedimentation during Early Cretaceous time is recorded by the conglomerates, sandstones, and siltstones of the lower part of the Dakota. Fine-grained sandstones and siltstones in the upper part of the Dakota Sandstone, deposited under marginal marine conditions, mark the transgression of the Cretaceous sea into the area. The Cretaceous sea covered large areas in the western part of the United States and covered the mapped area for a part of Early and a large part of Late Cretaceous time. Other deposits laid down in this sea include those of the Benton, the Niobrara, and the Pierre. The depth of 
the water at this place fluctuated as recorded by shallow-water sediments, such as the limy sandstone in the upper part of the Benton and deeper water shaly sediments of the Benton, the Niobrara, and the Pierre. Local unconformities within the marine sequence, such as near the base of the Niobrara, indicate that the Cretaceous sea retreated from the area at various times. In Late Cretaceous time after deposition of the Pierre, the sea retreated from the area. It is not known if deposits of Late Cretaceous age associated with the retreat of the sea east of the Front Range (Fox Hills Sandstone and Laramie Formation of Late Cretaceous age) were ever deposited in this area. If they were present in the mapped area they have been removed by erosion.

Toward the end of Cretaceous time much of the present structural framework of the region including North-Middle Park basin and the surrounding mountain ranges was established by crustal movements associated with uplift of the Rocky Mountains. These crustal movements that started in Cretaceous time and continued into early Tertiary time are generally referred to as the Laramide Revolution. Some plutonism and volcanism were associated with the uplift of the region. Continued uplift along the axes of the Front and Park Ranges and associated stripping of the sedimentary rock cover of the ranges exposed the Precambrian crystalline rocks along the axis of the ranges and locally in North-Middle Park basin. Faults within the mapped area that are associated with this initial Laramide uplift are the west-northwest-trending Corral Creek and Parshall faults.

The first sedimentary rocks in the mapped area that record the uplift of the surrounding areas during early Tertiary time and perhaps the latest part of Cretaceous time are of the Middle Park Formation. These rocks are rich in Precambrian detritus shed from the areas along the Park and Front Range axes and from isolated areas in Middle Park such as the Byers Canyon area. The Middle Park Formation covered the preexisting early Laramide structures including the west-northwest-trending Parshall and Corral Creek faults in the quadrangle. Volcanism to the east and southeast of the quadrangle in Middle Park time is recorded by large amounts of volcanic breccias (Windy Gap Member) at the base of the Middle Park Formation. That the Precambrian rocks were exposed prior to deposition of the breccias is shown by local conglomerates rich in clasts of Precambrian granitic rock beneath the breccias. A few dikes and plugs of intermediate composition were intruded in the area, and they were probably feeders for some of the breccias at the base of the Middle Park Formation. That plutonism in the Front Range occurred prior to or concurrent with deposition of the Middle Park is shown by rounded fragments of light-colored porphyritic igneous rock in the upper part of the Middle Park Formation. Recurrent volcanism in areas east and southeast of the area is shown by the volcanic breccias of Marietta Creek several hundred feet above the Windy Gap Volcanic Member of the Middle Park. After deposition of the Middle Park Formation and prior to deposition of the Rabbit Ears Volcanics, large crustal movements along the Williams Range and Vasquez overthrusts occurred in the region. In the mapped area, movement occurred along the Mount Bross section of the Vasquez overthrust system, and some renewed movement occurred along the Parshall fault.

In middle Tertiary time fragmental volcanic rocks and lavas and associated hypabyssal intrusives of the Rabbit Ears Volcanics record middle Tertiary volcanism in the Rabbit Ears Range. The fragmental rocks and lavas were deposited on a dissected terrain probably cut in late Eocene and early Oligocene time and locally covered the trace of the Mount Bross and Corral Creek faults. In North Park the volcanic rocks were deposited on the White River Formation of Oligocene age, but in Middle Park no sedimentary rocks of White River age have been found, and if they ever existed they were removed prior to deposition of the Rabbit Ears Volcanics. Intermontane basin-fill sediments of the Troublesome Formation of Miocene age, rich in tuffaceous rocks stripped from the adjoining highlands after an episode of middle Tertiary volcanism, were deposited in several small basins in Middle Park including a small area at the west edge of the quadrangle. Volcanism probably west or northwest of the area is shown by the air-fall ash deposits in the Troublesome. Renewed volcanism, probably in Pliocene time, caused the lava flows of the Grouse Mountain Basalt that locally overlie the Troublesome and the Rabbit Ears.

During early Pliocene time and after deposition of the Troublesome Formation, a period of folding and faulting occurred. In Pliocene time coarse boulder conglomerates were deposited over an area of upturned Middle Park beds in the northeastern part of the quadrangle. Middle to upper Pliocene sediments were deposited on the deeply eroded surface of the Troublesome Formation in the southwestern part of the area. These sediments are probably the oldest deposits related to the ancestral Colorado River drainage in the mapped area.

In Quaternary time the outlines of the present drainage patterns of the Colorado River were already established, and renewed regional uplift started erosion that formed the present relief. Alluviation along the streams and rivers in Quaternary time is shown by terrace deposits at several levels. Soil profiles were 
established on the alluvial deposits, and they are locally preserved in the area. Landslide, talus, and travertine deposits locally formed in the mapped area. Glaciation occurred in the mountains that surround the quadrangle, but deposits associated with the glaciation are not known in the mapped area.

\section{ECONOMIC GEOLOGY}

\section{COAL}

The chief purpose of the work was to evaluate lands in the northern part of the quadrangle in Tps. 2 and 3 N., Rs. 77, 78, and $79 \mathrm{~W}$., in which the Federal Government has retained mineral rights for coal. The land is underlain by rocks of the Middle Park Formation and was thought to be possibly valuable for coal deposits. Coal was mined from several thin coal beds near the base of the Middle Park Formation west of the mapped area at the Hartman mine in secs. 4 and 5, T. 3 N., R. 80 W., in the northern part of the Kremmling quadrangle. To the north in North Park, coal was mined from rocks that are probably partly equivalent to the Middle Park and are called the Coalmont Formation (Beekly, 1915; Hail, 1968).

No coal beds of economic importance were found in the area. An impure poor quality lignitic coal bed about 2 feet thick crops out at a few places in secs. 22 and 27, T. 2 N., R. $77 \mathrm{~W}$., in the lower part of the Middle Park Formation above the Windy Gap Member. In this area the Middle Park dips about $60^{\circ} \mathrm{W}$. Prospecting for coal on Federal lands in secs. 22 and 27 was done by J. C. Babb during about 1934-38, but no coal was produced from the area. Prospects for coal were seen at a few places in the area but all have long been abandoned. In 1935 four holes were drilled on Federal lands in connection with a coal prospecting permit in the $\mathrm{NW} / 4$ sec. $27, \mathrm{~T} .2 \mathrm{~N}$., R. $77 \mathrm{~W}$., to test for coal beds. None of the holes were deeper than 155 feet, and the only coaly beds found were dirty soft carbonaceous shale beds less than 1 foot thick. Another impure coal bed occurs above the Windy Gap Member in the NE $1 / 4$ sec. 1 , T. 1 N., R. 78 W., but the bed could be traced for only a short distance. Cross (1892, p. 210) mentioned an exploration shaft for coal "west of Glenn Sheriff's ranch" that probably explores the bed observed by the writer in sec. 1 . Thin discontinuous carbonaceous trash beds occur in the lower part of the Middle Park Formation at several places in the southwestern part of the quadrangle, but none can be classed as coal. Marvine (1874, p. 156) described a thin seam of coal in "the lower mid-cretaceous slates, a few hundred feet above the quartzitic sandstones of No. 1 [Dakota], at the Hot Springs." This thin coal seam must be in the Benton Shale, but the writer could not find the bed in the Benton exposed along the Colorado River.

\section{OIL AND GAS}

In 1957 two wells were drilled for oil and gas in the area (pl. 1), and several other wells have been drilled just outside the area along the Granby anticline, but none have produced gas or oil. One well, Murphy-Bill Hewit Corral Peak 1, was drilled on the upthrown side of the Mount Bross fault in sec. 4, T. 2 N., R. 78 W., and a log indicates about 1 foot of dead oil stain in the Pierre Shale. A sill about 35 feet thick of a light-colored igneous rock probably related to the Rabbit Ears Volcanics is reported to occur in the Benton Shale. The second well, Lion Oil Linke State 1, was drilled near the center of sec. 16, T. 1 N., R. 77 W., on the upthrown side of the Mount Bross fault. The well was started in the Pierre Shale near the Baculites gregoryensis zone of the Pierre and apparently ended in the Morrison. The thickness of the Pierre in the well below the $B$. gregoryensis zone is seemingly too great by a factor of 2 , which suggests either that the Pierre Shale dips more steeply than surface dips imply or that the bore hole passed through undetected faults or folds. On the cross section (pl. 1) the Pierre is interpreted to be thicker because of a reverse fault in a zone between the Mount Bross fault and the Granby anticline. No faults could be found at the surface, but the Pierre is poorly exposed. No show of oil was reported in the well, but small shows of gas were found in the Niobrara and Benton. Prospecting for oil and gas in the area is difficult because of the structural complexity of the area and Tertiary igneous activity. Nevertheless, the area has possible value because (1) fairly large areas of the quadrangle are underlain by Mesozoic sedimentary rocks that produce oil and gas in North Park and (2) structurally favorable areas for accumulation of oil and gas are known in the area. One area that seems to be structurally favorable for accumulation of oil and gas occurs north of the mapped area where the Mount Bross fault passes into a north-plunging anticline. Surface rocks in the area are the Middle Park Formation, but at depth a thick section of Mesozoic rocks probably occurs. Another structurally favorable area is along Blue Ridge anticline; it was drilled south of the area at Eason Oil 1 Government A, but no shows of oil and gas were reported.

\section{GILSONITE}

The occurrence of gilsonite in the Middle Park Formation several miles north of the quadrangle has been reported by several geologists including Eldridge (1901, p. 327-330), Beekly (1915), and Vine (1957), 
but none was found in the quadrangle. According to Vine, the gilsonite that is north of the area should be called grahamite, and it is black and brittle and resembles bituminous coal. Eldridge (1901) stated that the gilsonite occurs in steeply pitching veins.

\section{URANIUM}

Small concentrations of uranium minerals and anomalous zones of radioactivity have been reported in two places in the region. One area described by Malan (1957) as the Beaver Creek area is in secs. 14, 15, and 22, T. 1 N., R. 78 W., at the south end of Byers Canyon and was discovered in 1954. In this area the Middle Park Formation, which is the host rock, is a coarse arkosic grit that rests unconformably on the Precambrian granitic rocks. In the area of the Undecided and Lucky Jack prospects, according to Malan, autunite and an unidentified black uranium mineral occur mainly in a carbonaceous boulder-bearing bed as much as 2 feet thick at the base of the Middle Park; smaller concentrations of uranium minerals occur in an overlying reddish shale and in joints in the underlying quartz monzonite. At the time the writer visited the area, the prospects other than bulldozer cuts were inaccessible, and no uranium mineralization could be found. Apparently, the area has not produced any oregrade material.

Another area of uranium-mineral concentrations and areas of anomalous radioactivity occur west of the quadrangle east of Troublesome Creek. According to Malan (1957) and Schlottmann and Smith (1954), uranium minerals including carnotite, autunite, and schroeckingerite(?) occur in association with brown and green vanadium minerals in a carbonaceous sandy claystone and conglomerate in the lower 160 feet of the Troublesome Formation. Many shallow holes were drilled by the Atomic Energy Commission in 1954 in the Troublesome Formation east of Troublesome Creek to prospect for uranium. The area has not as yet produced any ore-grade material.

\section{GOLD}

Fine placer gold is reported to occur in stream gravels in the northern part of the area. Vanderwilt (1947) reported that small quantities of placer gold occur along Willow Creek north of Granby and that the production for the period 1934-37 was less than an ounce. Alluvial deposits along eastern tributaries of Willow Creek such as Gold Run, Hall, Denver, and Kauffman Creeks are purported to contain traces of gold. The source of the gold is unknown, but it may have been derived from reworking of the upper Tertiary gravel deposits at Little Gravel and Gravel Mountains.

\section{GRAVEL}

Gravel-bearing Quaternary terrace deposits that occur along the Colorado River and the Williams Fork have been locally excavated, sized, and used for road metal on the unimproved roads in the area. Gravel pits are in sec. 11, T. 1 N., R. 79 W., and in secs. 2, 3, and 16, T. 1 N., R. $78 \mathrm{~W}$., and at these localities large quantities of the gravel are available. Numerous other gravel sites close to main roads are accessible along the Colorado River and Williams Fork valleys.

\section{IIGHTWEIGHT AGGREGATE}

Pumiceous glassy rhyolite tuffs of the Rabbit Ears Volcanics that crop out in secs. 21, 22, 27, and 28, T. 2 N., R. 79 W., may be suitable for use as lightweight aggregate. A description of the rock is given on page 34 .

\section{FOSSIL LOCALITIES}

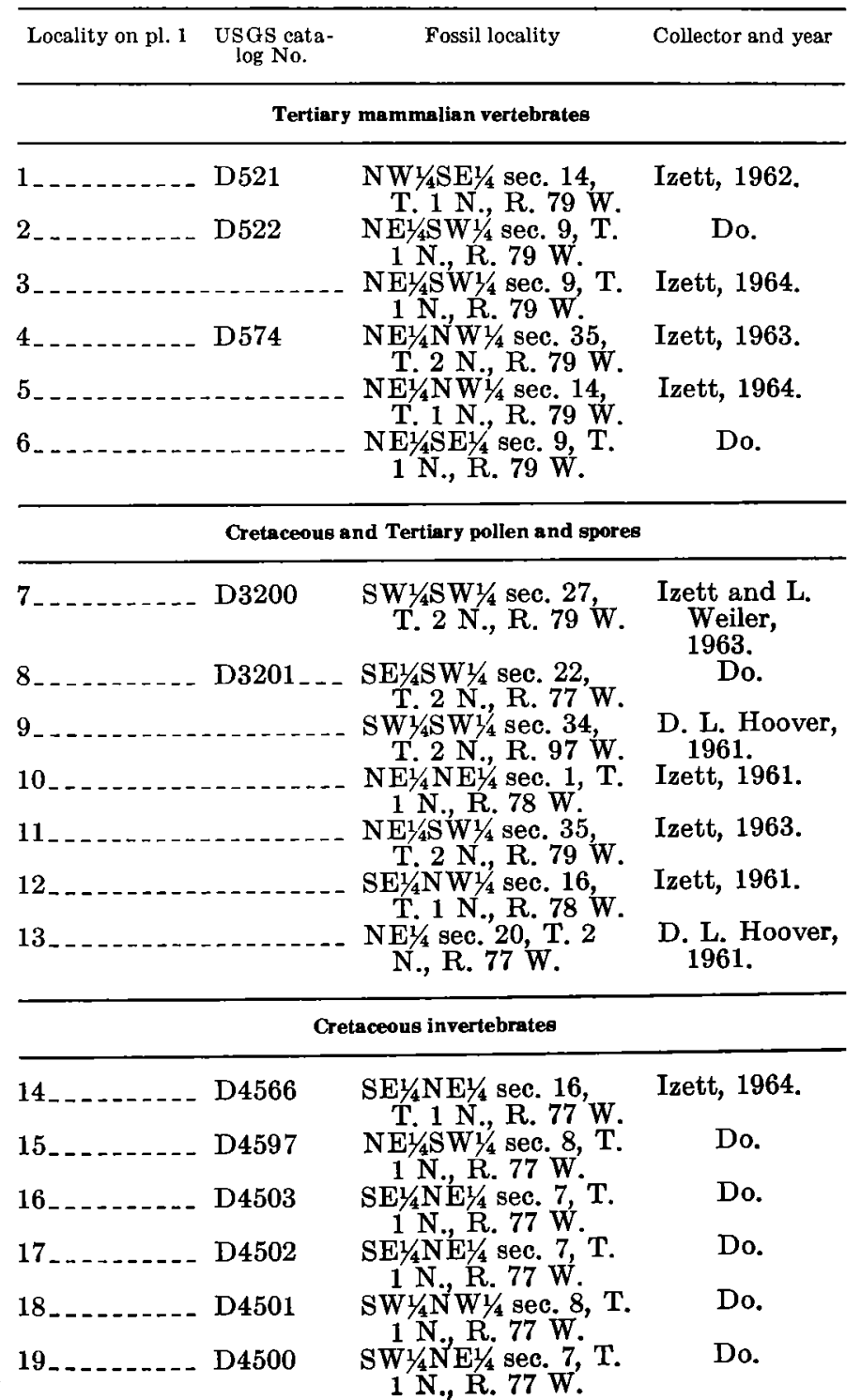


FOSSIL LOCALITIES-Continued

\begin{tabular}{|c|c|c|c|}
\hline Locality on pl. 1 & $\begin{array}{l}\text { USGS cata- } \\
\text { log No. }\end{array}$ & Fossil locality & Collector and year \\
\hline \multicolumn{4}{|c|}{ Cretaceous invertebrates - Con tinued } \\
\hline 20 & D4499 & $\begin{array}{l}\mathrm{NW}^{1 / 4} \mathrm{NE}^{1 / 4} \text { sec. } 7, \mathrm{~T} . \\
1 \mathrm{~N} ., \mathrm{R} .77 \mathrm{~W} .\end{array}$ & Do. \\
\hline 21 & $\mathrm{D} 4498$ & $\begin{array}{l}\mathrm{SE}^{1 / 4} \mathrm{NE} / 4 \text { sec. } 12, \\
\text { T. } 1 \text { N. R. } 78 \mathrm{~W} .\end{array}$ & Do. \\
\hline 22 & D3120 & $\begin{array}{l}\text { SW1/4SE1/4 sec. } 1, \mathrm{~T} . \\
1 \text { N., R. } 78 \mathrm{~W} .\end{array}$ & Izett, 1961. \\
\hline 23 & D3119 & $\begin{array}{l}\mathrm{NW}^{1 / 4} \mathrm{SE}_{1 / 4} \text { sec. } 1, \mathrm{~T} . \\
\mathbf{1} \text { N., R. } 78 \mathrm{~W} .\end{array}$ & Do. \\
\hline 24 & D1360 & $\begin{array}{l}\text { SW1/4NW1/4 sec. } 1, T . \\
1 \text { N., R. } 78 \text { W. }\end{array}$ & $\begin{array}{l}\text { Izett, W. A. } \\
\text { Cobban, } \\
\text { and G. R. } \\
\text { Scott, 1956, } \\
1964 .\end{array}$ \\
\hline$-\ldots$ & D1359 & $\begin{array}{l}\text { NW1/4NW1/4 sec. } 2, \\
\text { T. } 1 \text { N., R. } 78 \text { W. }\end{array}$ & $\begin{array}{l}\text { W. A. Cobban } \\
\text { and G. R. } \\
\text { Scott, } 1957 .\end{array}$ \\
\hline 26 & D4024 & $\begin{array}{l}\mathrm{NE}_{1 / 4}^{1} \mathrm{NW}_{1 / 4}^{1 / 4} \text { sec. } 2, \mathrm{~T} . \\
\mathbf{1} \text { N., R. } 78 \mathrm{~W} .\end{array}$ & Izett, 1963 \\
\hline 27 & D4025 & $\begin{array}{l}\text { SE1/4SW1/4 sec. } 35, \mathrm{~T} . \\
2 \text { N., R. } 78 \text { W. }\end{array}$ & Do. \\
\hline 28 & D3122 & $\begin{array}{l}\text { SE1/4SW1/4 sec. } 27, T . \\
2 \text { N., R. } 78 \text { W. }\end{array}$ & Izett, 1961. \\
\hline 29 & D3118 & $\begin{array}{l}\text { NE1/4NEY/4 sec. } 34, \\
\text { T. } 2 \text { N., R. } 78 \text { W. }\end{array}$ & Do. \\
\hline $30 \_$ & D4143 & $\begin{array}{l}\text { SW1/4NE1/4 sec. } 34, \\
\text { T. } 3 \text { N., R. } 77 \text { W. }\end{array}$ & $\begin{array}{l}\text { Izett, and W. } \\
\text { A. Cobban, } \\
\text { 1963-64. }\end{array}$ \\
\hline $31 \ldots \ldots$ & D3121 & $\mathrm{SW}_{1 / 4} \mathrm{NE}^{1 / 4}$ sec. 11 , & Izett, 1961 \\
\hline 32 & D3123 & 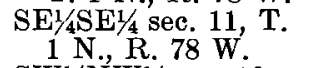 & Do. \\
\hline$-2-5$ & D4023 & $\begin{array}{l}\text { SW } 1 / 4 \mathrm{NW}^{1 / 4} \text { sec. } 10, \\
\text { T. } 1 \text { N., R. } 79 \text { W. }\end{array}$ & Izett, 1963. \\
\hline 34. & & $\begin{array}{l}\text { SW1/4SW1/4 sec. } 12, \\
\text { T. } 1 \text { N., R. } 78 \text { W. }\end{array}$ & Do. \\
\hline 35 & & $\begin{array}{l}\mathrm{NE}^{1 / 4 \mathrm{SE}^{1 / 4}} \text { sec. } 10, \mathrm{~T} . \\
1 \mathrm{~N} ., \mathrm{R} .79 \mathrm{~W} .\end{array}$ & Do. \\
\hline 36. & D4144 & $\begin{array}{l}\mathrm{NE}^{1 / 4 \mathrm{NE}^{1 / 4}} \text { sec. } 11 \\
\quad \text { T. } 1 \text { N., R. } 78 \text { W. }\end{array}$ & Do. \\
\hline 37. & D990 & $\begin{array}{l}\text { SW1/4N W1/4 sec. } 1, \text { T. } \\
1 \text { N., R. } 78 \text { W. }\end{array}$ & $\begin{array}{c}\text { W. A. Cobban } \\
\text { and G. R. } \\
\text { Scott, } 1956 .\end{array}$ \\
\hline 38 & $14270-74$ & $\begin{array}{l}\text { SW1/4SE1/4 sec. } 35, \mathrm{~T} \\
2 \text { N., R. } 78 \text { W. }\end{array}$ & $\begin{array}{l}\text { T. S. Lover- } \\
\text { ing, } 1928 \text {. }\end{array}$ \\
\hline
\end{tabular}

\section{REFERENCES CITED}

Adams, J. W., 1965, The visible region absorption spectra of rare-earth minerals: Am. Mineralogist, v. 50, p. 356-366.

Aramaki, Shigeo, and Lipman, Peter, 1965, Possible leaching of $\mathrm{Na}_{2} \mathrm{O}$ during hydration of volcanic glasses: Japan Acad. Proc., v. 41, no. 6, p. 467-470.

Austin, E. B., 1957, Corral Peak anticline, Grand County, Colorado, in Rocky Mtn. Assoc. Geologists Guidebook 9th Ann. Field Conf., North and Middle Park Basins, Colorado, 1957: p. 97-98.

Ball, S. M., 1906, Pre-Cambrian rocks of the Georgetown quadrangle, Colorado: Am. Jour. Sci., 4th ser., v. 21, p. 371-389.

Beekly, A. L., 1915, Geology and coal resources of North Park, Colorado: U.S. Geol. Survey Bull. 596, 121 p.

Billings, M. P., 1942, Structural geology: New York, PrenticeHall, Inc., $473 \mathrm{p}$.

Bombolakis, E. G., 1958, Geology of the Hot Sulphur SpringsParshall area of Middle Park, Grand County, Colorado: Colorado School of Mines master's thesis; Ann Arbor, Mich., University Microfilms, Inc.
Brown, R. W., 1949, Paleocene deposits of the Rocky Mountains and Plains: U.S. Geol. Survey Prelim, Map.

Burbank, W. S., Lovering, T. S., Goddard, E. N., and Eckel, E. B., 1935, Geologic map of Colorado; U.S. Geol. Survey.

Byers, F. M., Jr., Orkild, P. P., Carr, W. J., and Christiansen, R. L., 1964, Timber Mountain caldera, Nevada Test Site and vicinity-a preliminary report [abs.], in Abstracts for 1963: Geol. Soc. America Spec. Paper 76, p. 267.

Cady, R. C., and Scherer, O. J., 1946, Geology and ground-water resources of Box Butte County, Nebraska: U.S. Geol. Survey Water-Supply Paper 969, 102 p.

Cherkasov, Yu. A., 1957, O primenenii "fokalnogo ekranirovaniia" pri izmereniiakh pokazatelei prelomleniia immersionnym metodom (Application of "focal screening" to measurement of indices of refraction by the immersion method), in Rozhkova, E. V., ed., Sovremennye metody mineralogicheskogo issledovaniia gornykh porod, rud i mineralov (Modern methods of mineralogic investigation of rocks, ores and minerals): Moscow, Gosudarstvennoe Nauchno-Tekhnicheskoe Izdatel'stvo Literatury po Geologii i Okhrane Nedr., p. 184-207 (translated by Ivan Mittin in Internat. Geology Review, v. 2, 1960, p. 218-235)

Clark, W. B., 1891, Correlation papers-Eocene: U.S. Geol. Survey Bull. 83, $173 \mathrm{p}$.

Cockerell, T. D. A., 1908, A new locality for Miocene mammals: Science, new ser., v. 28, p. 683.

Cook, H. J., 1915, Notes on the geology of Sioux County, Nebraska, and vicinity: Nebraska Geol. Survey, v. 7, pt. 11, p. 59-75.

Corbett, M. K., 1965, Tertiary igneous petrology of the Mount Richthofen-Iron Mountain area, north-central Colorado [abs.], in Abstracts for 1964: Geol. Soc. America Spec. Paper 82, p. 324-325.

Cross, C. W., 1892, The post-Laramie beds of Middle Park, Colorado: Colorado Sci. Soc. Proc., v. 4, p. 192-213.

Daly, R. A., 1933, Igneous rocks and the depths of the earth: New York, McGraw-Hill Book Co., 508 p.

Darton, N. H., 1903, Preliminary report on the geology and water resources of Nebraska west of the one hundred and third meridian: U.S. Geol. Survey Prof. Paper 17, 69 p.

Denson, N. M., 1965, Miocene and Pliocene rocks of central Wyoming, in Cohee, G. V., and West, W. S., Changes in stratigraphic nomenclature by the U.S. Geological Survey, 1964: U.S. Geol. Survey Bull. 1224-A, p. 70-74.

Eldridge, G. H., 1901, The asphalt and bituminous rock deposits of the United States: U.S. Geol. Survey Ann. Rept. 22, pt. 1, p. 209-452.

Elias, M. K., 1942, Tertiary prairie grasses and other herbs from the High Plains: Geol. Soc. America Spec. Paper 41, 176 p.

Emmons, S. F., 1890, Orographic movements in the Rocky Mountains: Geol. Soc. America Bull., v. 1, p. 245-286.

Engel, A. E. J., Engel, C. G., and Havens, R. G., 1965, Chemical characteristics of oceanic basalts and the upper mantle: Geol. Soc. America Bull., v. 76, no. 7, p. 719-734.

Evernden, J. F., Savage, D. E., Curtis, G. H., and James, G. T., 1964, Potassium-argon dates and the Cenozoic mammalian chronology of North America: Am. Jour. Sci., v. 262, no. 2, p. $145-198$.

Fyfe, W. S., Turner, F. J., and Verhoogen, John, 1958, Metamorphic reactions and metamorphic facies: Geol. Soc. America Mem. 73, 259 p.

Galbreath, E. C., 1953, A contribution to the Tertiary geology and paleontology of northeastern Colorado: Kansas Univ, Paleont. Contr. 13, Vertebrata, art. 4, 119 p. 
Goodman, A. J., 1951, White specks in Colorado Shale [Canada]: Am. Assoc. Petroleum Geologists Bull., v. 35, no. 11, p. $2427-2429$.

Grout, F. F., Worcester, P. G., and Henderson, Junius, 1913, Reconnaissance of the geology of the Rabbit Ears region, Routt, Grand, and Jackson Counties, Colorado: Colorado Geol. Survey Bull. 5, pt. 1, p. 1-57.

Hail, W. J., Jr., 1965, Geology of northwestern North Park, Colorado: U.S. Geol. Survey Bull. 1188, 133 p. 1968, Geology of southwestern North Park and vicinity, Colorado: U.S. Geol. Survey Bull. 1257 (in press).

Hail, W. J., Jr., and Leopold, E. B., 1960, Paleocene and Eocene age of the Coalmont Formation, North Park, Colorado, in Short papers in the geological sciences: U.S. Geol. Survey Prof. Paper 400-B, p. B260-B261.

Hail, W. J., Jr., and Lewis, G. E., 1960, Probable late Miocene age of the North Park formation in the North Park area, Colorado, in Short papers in the geological sciences: U.S. Geol. Survey Prof. Paper 400-B, p. B259-B260.

Harrison, J. E., and Wells, J. D., 1956, Geology and ore deposits of the Freeland-Lamartine district, Clear Creek County, Colorado: U.S. Geol. Survey Bull. 1032-B, p. 33-127.

Hayden, F. V., 1869, Preliminary field report [third annual] of the U.S. Geol. Survey of Colorado and New Mexico: Washington, U.S. Govt. Printing Office, $155 \mathrm{p}$.

Hinrichs, E. N., and Orkild, P. P., 1961, Eight members of the Oak Spring formation, Nevada Test Site and vicinity, Nye and Lincoln Counties, Nevada, in Short papers in the geologic and hydrologic sciences: U.S. Geol. Survey Prof. Paper 424-D, p. D96-D103.

Holt, H. E., 1961, Geology of the lower Blue River area, Summit and Grand Counties, Colorado: Colorado Univ. Ph. D. thesis; Ann Arbor, Mich., University Microfilms, Ine.

Izett, G. A., 1965, Preliminary geologic map of the Hot Sulphur Springs NW quadrangle, Grand County, Colorado: U.S. Geol. Survey open-file map.

- 1966, Tertiary extrusive volcanic rocks in Middle Park, Grand County, Colorado, in Geological Survey research 1966: U.S. Geol. Survey Prof. Paper 550-B, p. B42-B46.

Izett, G. A., and Hoover, D. L., 1963, Preliminary geologic map of the Hot Sulphur Springs SE quadrangle, Grand County, Colorado: U.S. Geol. Survey Mineral Inv. Map MF-271.

Izett, G. A., and Lewis, G. E., 1963, Miocene vertebrates from Middle Park, Colorado, in Short papers in geology and hydrology: U.S. Geol. Survey Prof. Paper 475-B, p. B120B122.

Izett, G. A., Taylor, R. B., and Hoover, D. L., 1963, Windy Gap Volcanic Member of the Middle Park Formation, Middle Park, Colorado, in Short papers in geology, hydrology, and topography: U.S. Geol. Survey Prof. Paper 450-E, p. E36E39.

Izett, G. A., and Barclay, C. S. V., 1964, Preliminary geologic map of the Hot Sulphur Springs SW quadrangle, Grand County, Colorado: U.S. Geol. Survey Mineral Inv. Map MF-291.

Jenkens, M. A., Jr., 1957, Stratigraplyy of the Red Dirt Creek area, Grand County, Colorado, in Rocky Mtn. Assoc. Geologists Guidebook 9th Ann. Field Conf., North and Middle Park Basins, Colorado, 1957: p. 51-54.

Kinney, D. M., and Hail, W. J., Jr., 1959, Upper Cretaceous rocks in North Park, Jackson County, Colorado, in Rocky Mtn. Assoc. Geologists, Symposium on Cretaceous rocks of Colorado and adjacent areas, 1959: p. 105-1.09.

Knopf, Adolph, 1936, Igneous geology of the Spanish Peaks region, Colorado: Geol. Soc. America Bull., v. 47, no. 11, p. $1727-1784$.

Knowlton, F. H., 1930, The flora of the Denver and associated formations of Colorado: U.S. Geol. Survey Prof. Paper 155, $142 \mathrm{p}$.

Kuno, Hisashi, 1950, Petrology of the Hakone volcano and the adjacent areas, Japan: Geol. Soc. America Bull., v. 61, no. 9, p. 957-1019.

Lakes, Arthur, 1905, Geology of the hot springs of Colorado and speculations as to their origin and heat; Colorado Sci. Soc. Proc., v. 8, p. 31-37.

Larsen, E. S., Jr., and Cross, C. W., 1956, Geology and petrology of the San Juan region, southwestern Colorado: U.S. Geol. Survey Prof. Paper 258, 303 p.

Lee, W. T., 1917, The geologic story of Rocky Mountain National Park, Colorado: U.S. Natl. Park Service, 89 p.

Leidy, Joseph, 1873, Contributions to the extinct vertebrate fauna of the Western Territories: U.S. Geol. Geog. Survey Terr. (Hayden), v. 1, $358 \mathrm{p}$.

Lipman, P. W., 1965, Chemical comparison of glassy and crystalline volcanic rocks: U.S. Geol. Survey Bull. 1201-D, $24 \mathrm{p}$.

Love, J. D., 1961, Split Rock formation (Miocene) and Moonstone formation (Pliocene) in central Wyoming: U.S. Geol. Survey Bull. 1121-I, 39 p.

Lovering, T. S., 1930, The Granby anticline, Grand County, Colorado: U.S. Geol. Survey Bull. 822-B, p. 71-76.

Lovering, T. S., and Goddard, E. N., 1950, Geology and ore deposits of the Front Range, Colorado: U.S. Geol. Survey Prof. Paper 223, 318 p.

Lugn, A. L., 1939, Classification of the Tertiary system in Nebraska: Geol. Soc. America Bull., v. 50, no. 8, p. 12451275.

MacDonald, G. A., 1942, Potash-oligoclase in Hawaiian lavas: Am. Mineralogist, v. 27, no. 12, p. 793-800.

McGrew, L. W., 1967, Geologic map of the Casebier Hill quadrangle, Goshen County, Wyoming: U.S. Geol. Survey Geol. Quad .Map GQ-621.

McGrew, P. O., 1951, Tertiary stratigraphy and paleontology of south-central Wyoming, in Wyoming Geol. Assoc. Guidebook 6th Ann. Field Conf., South-central Wyoming, 1951: p. 54-57.

1953, Tertiary deposits of southeastern Wyoming, in Wyoming Geol. Assoc. Guidebook 8th Ann. Field Conf., Laramie basin, Wyoming, and North Park, Colorado, 1953: p. 61-64.

McKee, E. D., and Weir, G. W., 1953, Terminology for stratification and cross-stratification in sedimentary rocks: Geol. Soc. America Bull., v. 64, no. 4, p. 381-389.

McKenna, M. C., 1965, Stratigraphic nomenclature of the Miocene Hemingford Group, Nebraska: Am. Mus. Novitates, no. 2228,21 p.

Malan, R. C., 1957, Geology of uranium occurrences in North and Middle Parks, Colorado, in Rocky Mtn. Assoc. Geologists Guidebook 9th Ann. Field Conf., North and Middle Park Basins, Colorado, 1957: p. 126-136.

Malde, H. E., 1961, Patterned ground of possible solifiuction origin at low altitude in the Western Snake River Plain, Idaho, in Short papers in the geologic and hydrologic sciences: U.S. Geol. Survey Prof. Paper 424-B, p. B170-B173.

Marvine, A. R., 1874, Report [on the Middle Park region, Colo.], in Hayden, F. V., Seventh Annual Report of the U.S. Geological and Geographical Survey of the Territories $* * *$ for the year 1873: Washington, U.S. Govt. Printing Office, p. 83-192. 
Matthew, W. D., 1901, Fossil mammals of the Tertiary of northeastern Colorado: Am. Mus. Nat. History Mem., v. 1 , pt. 7 , p. $355-447$.

1924, Third contribution to Snake Creek fauna: Am. Mus. Nat. History Bull., v. 50, p. 59-425.

Matthew, W. D., and Cook, H. J., 1909, A Pliocene fauna from western Nebraska: Am. Mus. Nat. History Bull., v. 26, p. 361-414.

Mertie, J. B., Jr., 1922, Igneous rocks, in Lee, W. T., Description of the Raton, Brilliant, and Koehler quadrangles [New Mexico and Colorado]: U.S. Geol. Survey Geol. Atlas, Folio 214, p. 9-12.

Miles, C. H., 1961, The geology of the Pass Creek-Wolford Mountain area, Grand County, Colorado: Golden, Colorado School Mines master's thesis.

Moench, R. H., Harrison, J. E., and Sims, P. K., 1962, Precambrian folding in the Idaho Springs-Central City area, Front Range, Colorado: Geol. Soc. America Bull., v. 73, no. 1, p. $35-58$.

Montagne, J. M. de la, 1955, Cenozoic history of the Saratoga Valley area, Wyoming and Colorado: Wyoming Univ. Ph. D. thesis; Ann Arbor, Mich., University Microfilms, Inc.

Montagne, J. M. de la, and Barnes, W. C., 1957, Stratigraphy of the North Park Formation in North Park area, Colorado, in Rocky Mtn. Assoc. Geologists Guidebook 9th Ann. Field Conf., North and Middle Park Basins, 1957: p. 55-60.

Noble, D. C., and others, 1965, Close association in space and time of alkalic, calc-alkalic, and cal cic volcanism in southern Nevada [abs.], in Abstracts for 1964: Geol. Soc. America Spec. Paper 82, p. 143-144.

Nockolds, S. R., 1954, Average chemical compositions of some igneous rocks: Geol. Soc. America Bull., v. 65, no. 10, p. 1007-1032.

Osborn, H. F., 1918, Equidae of the Oligocene, Miocene, and Pliocene of North America, iconographic type revision: Am. Mus. Nat. History Mem., new series, v. 2, pt. 1, p. $1-330$.

Peacock, M. A., 1931, Classification of igneous rock series: Jour. Geology, v. 39, no. 1, p. 54-67.

Pepper, J. F., de Witt, Wallace, Jr., and Demarest, D. F., 1954, Geology of the Bedford shale and Berea sandstone in the Appalachian basin: U.S. Geol. Survey Prof. Paper 259, $111 \mathrm{p}$.

Richards, Arthur, 1941, Geology of the Kremmling area, Grand County, Colorado: Michigan Univ. Ph. D. thesis; Ann Arbor, Mich., University Microfilms, Inc.

Sanders, R. J., 1957, Geology of Granby anticline [Colo.], in Rocky Mtn. Assoc. Geologists Guidebook 9th Ann. Field Conf., North and Middle Park Basins, Colo., 1957, p. 67-69.

Sato, Yoshiaki, and Denson, N. M., 1967, Volcanism and tectonism as reflected by the distribution of nonopaque heavy minerals in some Tertiary rocks of Wyoming and adjacent States, in Geological Survey research 1967: U.S. Geol. Survey Prof. Paper 575-C, p. C42-C54.

Schlottmann, J. D., and Smith, L. E., 1954, Preliminary report on uranium mineralization in the Troublesome Formation, Middle Park, Grand County, Colorado: U.S. Atomic Energy Comm. Rept. RME-1042, 14 p.

Schultz, C. B., 1938, The Miocene of western Nebraska: Am. Jour. Sci., 5th ser., v. 35 , no. 210 , p. 441-444.

Schultz, C. B., and Stout, T. M., 1961, Field conference on the Tertiary and Pleistocene of western Nebraska: Nebraska Univ. State Mus. Spec. Pub. 2, 55 p.
Scott, G. R., 1962, Geology of the Littleton quadrangle, Jefferson, Douglas, and Arapahoe Counties, Colorado: U.S. Geol. Survey Bull. 1121-L, 53 p.

1963, Quaternary geology and geomorphic history of the Kassler quadrangle, Colorado: U.S. Geol. Survey Prof. Paper 421-A, 70 p.

Scott, G. R., and Cobban, W. A., 1965, Geologic and biostratigraphic map of the Pierre Shale between Jarre Creek and Loveland, Colorado: U.S. Geol. Survey Misc. Geol. Inv. Map I-439.

Shapiro, Leonard, and Brannock, W. W., 1962, Rapid analysis of silicate, carbonate, and phosphate rocks: U.S. Geol. Survey Bull. 1144-A, 56 p.

Shearer, E. M., 1957, Geology of the Hot Sulphur Springs area, Grand County, Colorado, in Rocky Mtn. Assoc. Geologists Guidebook 9th Ann. Field Conf., North and Middle Park Basins, Colorado, 1957: p. 99-103.

Sims, P. K., Phair, George, and Moench, R. H., 1958, Geology of the Copper King uranium mine, Larimer County, Colorado: U.S. Geol. Survey Bull. 1032-D, p. 171-221.

Sims, P. K., and Gable, D. J., 1964, Geology of Precambrian rocks, Central City district, Colorado: U.S. Geol. Survey Prof. Paper 474-C, 52 p.

Sitter, L. U. de, 1956, Structural geology: New York, McGrawHill Book Co., 552 p.

Steven, T. A., and Ratté, J. C., 1960, Relation of mineralization to caldera subsidence in the Creede district, San Juan Mountains, Colorado, in Short papers in the geological sciences: U.S. Geol. Survey Prof. Paper 400-B, p. B14-B17.

Steven, T. A., Mebnert, H., and Obradovich, J. D., 1967, Age of volcanic activity in the San Juan Mountains, Colorado, in Geological Survey research 1967: U.S. Geol. Survey Prof. Paper 575-D, p. D47-D55.

Stobbe, H. R., 1949, Petrology of volcanic rocks of northeastern New Mexico: Geol. Soc. America Bull., v. 60, no. 6, p. 1041-1095.

Swineford, Ada, Frye, J. C., and Leonard, A. B., 1955, Petrography of the late Tertiary volcanic ash falls in the central Great Plains: Jour. Sed. Petrology, v. 25, no. 4, p. 243-261.

Tollefson, O. W., 1955, Geology of central Middle Park, Colorado: Colorado Univ. Ph. D. thesis; Ann Arbor, Mich, University Microfilms, Inc.

Tröger, W. E., 1935, Spezielle Petrographie der Eruptivgesteine-Ein Nomenklatur-Kompedium: Berlin, Verlag der Deutschen Mineralogischen Gesellschaft, $360 \mathrm{p}$.

Tweto, Ogden, 1945, Vasquez overthrust, Middle Park, Colorado [abs.]: Geol. Soc. America Bull., v. 56, no. 12, p. 1208.

1947, Precambrian and Laramide geology of the Vasquez Mountains, Colorado: Michigan Univ. Ph. D. thesis; Ann Arbor, Mich., University Microfilms, Inc.

- 1957, Geologic sketch of southern Middle Park, Colorado, in Rocky Mtn. Assoc. Geologists Guidebook 9th Ann. Field Conf., North and Middle Park Basins, Colorado, 1957: p. 18-31.

U.S. Weather Bureau, 1933, Western Colorado, sec. 22, in Climatic summary of the United States: p. 22-1-22-33.

Vanderwilt, J. W., 1947, Mineral resources of Colorado: Denver, Colo., Mineral Resources Board, 547 p.

Van Tuyl, F. M., and Lovering, T. S., 1935, Physiographic development of the Front Range: Geol. Soc. America Bull., v. 46, no. 9, p. 1291-1350.

Vine, J. D., 1957, Grahamite deposit near Willow Creek Pass, Grand County, Colorado, in Rocky Mtn. Assoc. Geologists Guidebook 9th Ann. Field Conf., North and Middle Park Basins, Colorado, 1957: p. 125. 
Voegeli, P.T., Sr., 1965, Ground-water resources of North Park and Middle Park, Colorado-a reconnaissance: U.S. Geol. Survey Water-Supply Paper 1809-G, 54 p.

Waage, K. M., 1955, Dakota group in northern Front Range foothills, Colorado: U.S. Geol. Survey Prof. Paper 274-B, p. 15-51.

Wahlstrom, E. E., 1947, Cenozoic physiographic history of the Front Range, Colorado: Geol. Soc. America Bull., v. 58, no. 7, p. 551-572.

Wanek, A. A., 1963, Geologic map of the Hot Sulphur Springs NE quadrangle, Grand County, Colorado: U.S. Geol. Survey open-file map.

Weber, W. A., 1965, Plant geography in the Southern Rocky Mountains, in Wright, H. E., Jr., and Frey, D. G., eds., The Quaternary of the United States: Princeton, N. J., University Press, p. 453-468.

Wilcox, R. E., 1954, Petrology of Paricutin volcano, Mexico: U.S. Geol. Survey Bull. 965-C, p. 281-353.

1959, Use of the spindle stage for determination of principal indices of refraction of crystal fragments: Am. Mineralogist, v. 44, nos. 11-12, p. 1272-1293.

-1962, Cherkasov's "focal screening" for determination of refractive index by the immersion method, in McCrone,
W. C., ed., Proceedings of the International Microscopy Symposium, Chicago, 1960 [1962]: Chicago, Ill., McCrone Associates, p. 160-165.

1965, Volcanic-ash chronology, in Wright, H. E., Jr., and Frey, D. G., eds., The Quaternary of the United States: Princeton, N. J., University Press, p. 807-816.

Williams, Howel, 1942, The geology of Crater Lake National Park, Oregon, with a reconnaissance of the Cascade Range southward to Mount Shasta: Carnegie Inst. Washington Pub. 540, 162 p.

Wood, H. E., and others, 1941, Nomenclature and correlation of the North American continental Tertiary: Geol. Soc. America Bull., v. 52, no. 1, p. 1-48.

Wrucke, C. T., 1965, Prehnite and hydrogarnet(?) in Precambrian rocks near Boulder, Colorado, in Geological Survey research 1965: U.S. Geol. Survey Prof. Paper 525-D, p. D55-D58.

Young, E. J., and Sims, P. K., 1961, Petrography and origin of xenotime and monazite concentrations, Central City district, Colorado: U.S. Geol. Survey Bull. 1032-F, p. 273-299.

Zirkel, Ferdinand, 1876, Microscopical petrography: U.S. Geol. Explor. 40th Parallel (King), v. 6, 297 p. 


\section{INDEX}

[Italic page numbers indicate major references]

A

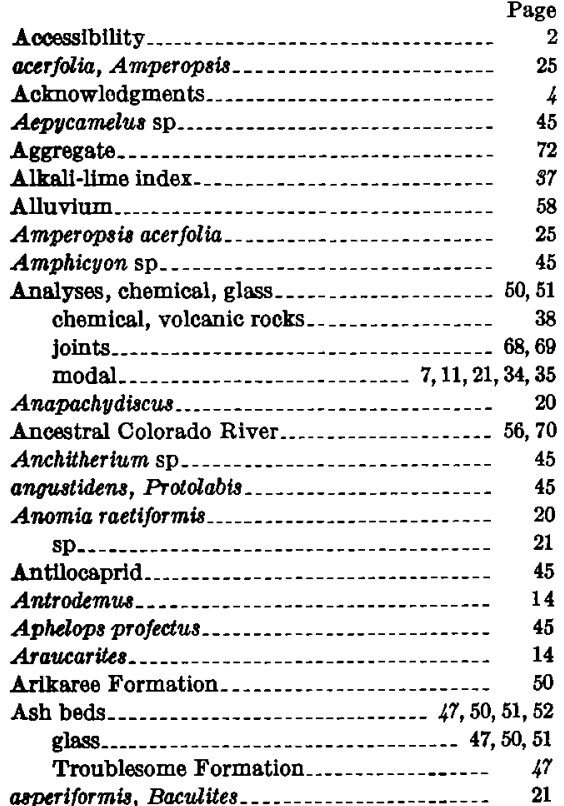

B

Baculites........... 20,21

asperiformis........ 21

compressus.

cuneatus_._.

gaberti_............ 20

gregoryensis

mclearni................ 21

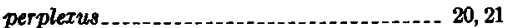

reesidel.

rugosus.-_-_-_-_- 20

8 cotti._..... 20

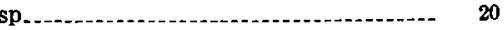
See also Zones.

Basalt_..................... 54, 55

Benton-Dakots contact........- 17

Benton-Niobrara contact.......... 18

Benton Shale.......... 5, 6, 17

hespy-mineral assemblage............... $\quad 59$

Juana Lopez equivalent.

mossured section . . .

Biotite gneiss_....... . ......................... 5,6

mineral assemb lage.................... 7

model analysis . .

origin

Biotito-quartz diorite........................ 11

modal anal ysis........ 11

Blastomerycine............... 45

Blue Ridge anticline............... 6, 67

Boulder conglomerate of Gravel Mountain _- 6,55

Boulder Creek Granodiorite................... 5, 10 inclusions in quartz monzonite......... 12

modal analysis........................... 11

Boulder Creek Granodiorite-Troublesome contact.

Brachycrus sp.

Breccia, Rabbit Ears Volcanics

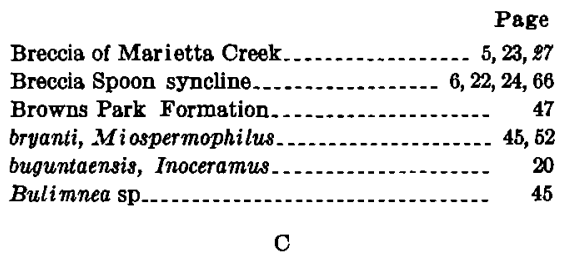

Camelid.

Camplocythere sp.... 14

Carayapollenites sp...................... 25

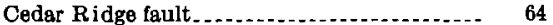

Chemical analyses, glass volcanic rocks.............. 38

Chiropteran

Chugwater Formation.................. 13

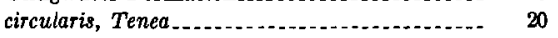
Thet is

Clams.

Coal..................... 71

Coalmont equivalent...................... 22

Coalmont Formation .................... 2, 22

Colorado River............................. 4

congesta, Ostrea...... 18

Conglomeratic facies, Troublesome Formation

Corral Creek fault

Corra l Peaks anticline...................... 66

Crassatella sp.............................. $\quad 20$

Cretaceous rocks, Benton Shale_.......... 5,6,17

Middle Park Formation $\ldots \ldots \ldots \ldots, \ldots, 28$

Niobrara Formation.................... 5, 6, 18

Pierre Shale.......................... 5, 6, 19, 29

Cretaceous sea

Cricetids.................. 45

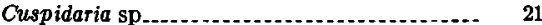

CW ash

cycloides, Inoceramus......-...- 20

Cymbophora sp.............. 20

\section{D}

Dakota-Benton contact......... 17

Dakota Sandstone......................... 5, 6,14

depositional environment $\quad 15,60$

heavy-mineral assemblage.............- 59

measured section.

dakotaensis, Euspira...................... 20

Darwinula spp. ......................... 14

Denver Formation.

Depositional environment, Dakota San dstone_. 15,69

Middle Park Formation

Morrison Formation.......... 60

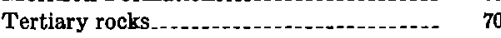

Troublesome Formation............. 41, 43, 70

Windy Gap Voleanic Member........ $\quad 70$

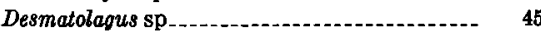

Didymoceras..

sp

Dikes....... $31,54,55,66,70$

dimidius, Inoceramus.......... 17

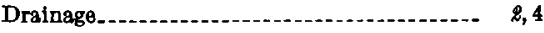

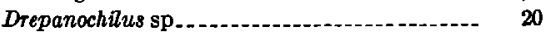

$\mathbf{E}$

East Fork Troublesome Creek

Ellipsoscapha occidenlatis...

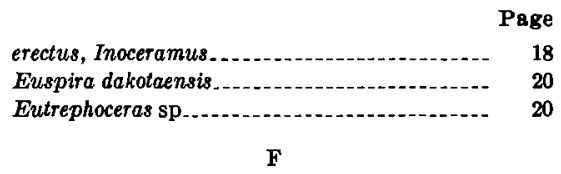

Faults 63,70

Feldspar ................

Felid, machaerodontine....... 45

Folds

Foliation--.-- 8, 10

Fossil localities........ 78

Fossil soils......

Fossil zones. See Zones.

Fossils, leaves. .

Middle Park Formation.

Niobrara Formation...................... 18

Pierre Shale.......... 20

pollen................. 25, 44

Troublesome Formation............... 41, 44

vertebrates.............. 44, 45

Front Range Highland.

\section{G}

Gas...

Geologic history, regional.

Geomyid...

Gilsonite.

chemical analyses.......... 50,51

Gold _..... 72

Goniomya sp..................... 20

Grangerimus sp....... 45, 62

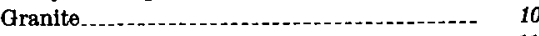

modal analysis. ........................... 11

Gravel deposits........... 55, 72

gregoryensis, Baculites

Grouse Mountain Basalt.................... 6,58

Grouse Mountain Basalt-Troublesome contact.

\section{H}

Heavy minerals

Heavy-mineral assemblage, Benton Shale....

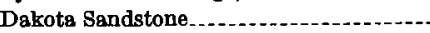

Mesozolc rocks

Middle Park Formation

Morrison Formation.

Tertiary rocks

Troublesome Formation

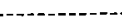

Windy Gap Volcanic Member............

Hesperocamelus $\mathrm{sp}$.

Heteromyid.

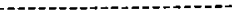

(1)

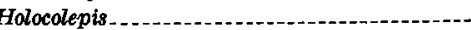

Hoploscaphites sp........ 20, 21

I

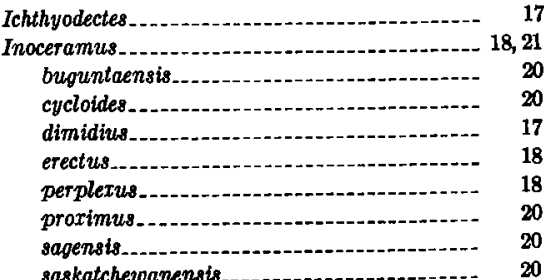




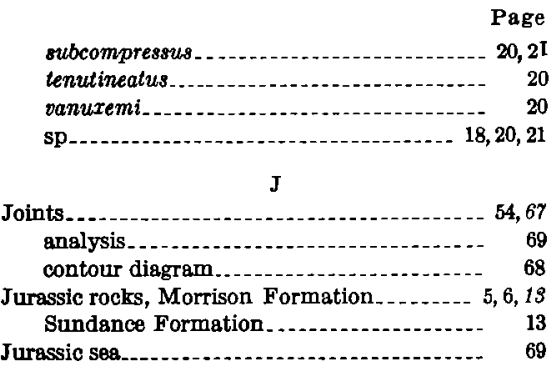

$\mathbf{L}$

laevis, Mesogaulus

Landslide deposits.

Laramide Revolution

Larimide tecton ism

Lava flows. -

Leucichthyops

Lima sp.

Limatula sp.

Limnoecus...

linouaeformis, Pteric

Lower Cretaceous Series, Dakota Sandstone.

Lucina subundata.............................

Lucky Jack prospect, uranium . . . . . . ...........

Lymnae sp.

M

magnum, Viburnum marslandensis, Metechinus........... 45

melearni, Baculites................... 21

Measured section, Benton Shale........ 16, 18, 19

Dakota Sandstone................... 15

Middle Park Formation................ $\$ 8$

Morrison Formation

Niobrara Formation ....................... 18

Pliocene deposits. . . . .

Troublesome Formation................. 52, 53

Windy Gap Volcanic Member............ 28, 29

Merychippus sejunctus................ 45

sp.

Mervcochoer $u s$.

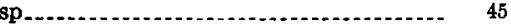

Merycodont............................. 45

Merycoidodont..... 45, 47

Mesogaulus laevis........................... 45

paniens $i$ s.

sp.

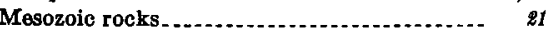

depositional environment

heavy-mineral assemblege

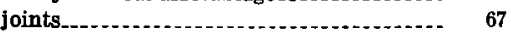

Morrison Formation.................... 19

Metacypris.......... 14

Metechinus marslandensis...................... 45

Middle Park

Middle Park basin. ........................... 61

Middle Park Formation

breccia of Marietta Creek._......... 5, 23, 27

Breccia Spoon syncline.............. 6, 22, 24,66

cosl

depositional environment................ 70

folds............ 63

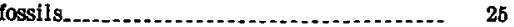

heavy,mineral assemb lage $\ldots . . . . . . . . . . . \quad 58$

joints_......................................... 67

measured section.......................... 28

Windy Gap Volcanic Member $\ldots \ldots$ 5, 23, 26

Middle Park-Pierre con tact

Middle Park-Rabbit Ears contact.......... 36

Middle Park-Troublesome contact........... 43

Milocene, stratigraphic div ision............... 46

Miocene rocks, correlation................. 48

Rabbit Ears Volcanies................. 29

Troublesome Formation............... 40

Miospermophilus bryanti.

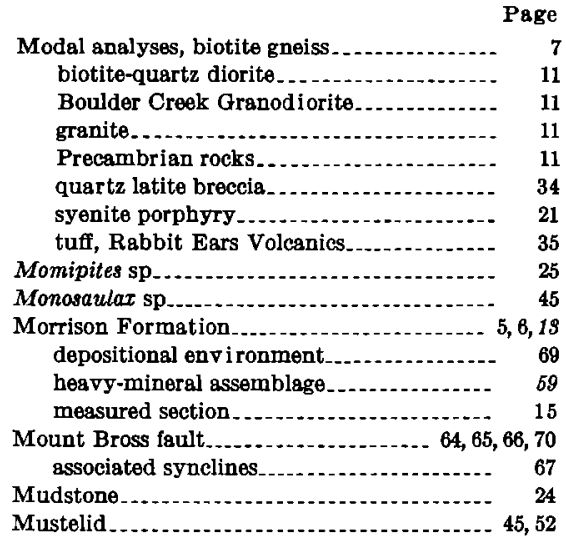

\section{$\mathbf{N}$}

nebrascana, Oxytoma.......... 20

Niobrara-Benton contact................... 18

Niobrara Formation....... 5, 6, 18

Niobrara-Pierre contact...................... 19

Niobrara - Troublesome contact.............. 43

Normativ e minerals, volcanic rocks.......... 39

North-Middle Park basin. . . . . . . . . . . ......... 22, 61

North Park basin....................... 61

North Park Formation.............. 47

\section{O}

occidentalis, Ellipsoscapha.-............. 20

Ochotonid

sp

Oligocene rocks, Rabbit Ears Volcanics._._. 6, 29,70

Optical properties, volcanic rocks............ 33, 36

Ostracodes............ 14

Ostrea congesta............................ 18

sp

Oxydactylus

Oxytome nebrascana.

$\mathbf{P}$

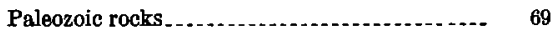
paniensis, Mesogaulus....................... 52

Parahippus.................................. 46

parkensis, Pteria

Parshall fault_........................... 63,64,70

Pawnee Creek Formation $\quad 47$

Permian rocks, Chugwater Formation........ 13

perplexus, Baculites....... 21

Inoceramus.

Pete Gulch Member

Pierre-Middle Park contact.................. 24, 25

Pierre-Niobrara contact...................... $\quad 19$

Pierro-Niobrara stratigraphic-fault relation... $\quad 65$

Pierre-Precambrian contact. .............. 63

Pierre Shale........ 5, 6, 19, 29

fossils_................................. 20

intrusives. 21

Placenticeras sp.-.......................... 20

Platanus raynoldsi............................. $\quad 25$

Pleistocene deposits. . ............... 6, 6, 57

Plesiosminthus sp._._................... 45

Pliocene deposits .......... 55, 56

Pliocene rocks, Grouse Mountain Basalt...... 53

Plugs__.............................. 40, 70

Plutonism

Precambrian-Pierre contact................... 63

Precambrian rocks. . .

biotite-quartz diorite................. 11

Boulder Creek Granodiorite................ 10

granite_._- 10

joints.

metamorphism

quartz monzonite.............. 5,18

tectonism
Page

Precipitation............................... 4

Prionocyclus..................................... 18 wyomingensis....... 17

Procamelus.

profectus, Aphelops

Promylagaulus s

Proteacidites sp. .

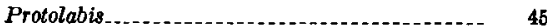

angustidens...... 45

proximus, Inoceramus.

Pteria linguaformis........ 20

parkensis...-......................... 20

sp................... 20, 21

Q

Quartz latite breccia modal analysis................. 34

Quartz monzonite..... 5,18 modal analysis.......... 11

Quartz-rich gneiss.......................... 7

Quartzo-feldspathic bands, biotite gneiss ..... 7

Quaternary deposits..... geologic history.

$\mathbf{R}$

Rabbit Ears-Middle Park contact............. $\quad 36$

Rabbit Ears-Troublesome contact._....... 36

Rabbit Ears Voleanies. alkall-lime index breccia contact relations. 36

Pete Gulch Member. petrochemistry ................... $\quad 37$

quartz latite breccia.

rhyolite breccia

trachyandesite........... 36

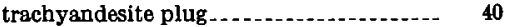

tuff

tuff breccia....... $\$ 1$

raetiformis, Anomia

raynoldsi, Platanus

Recent deposits. ..... 5, 6, 58

Rhyolite breccia, Rabbit Ears Volcanics...... $\quad 31$

sagensis, Inoceramus._.................... 20

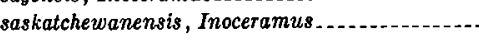
Scaphites.-

sp. Sciurid

scotti, Bacutiles.

Sedimentation patterns, Middle Park Formation.................

sejunctus, Merychippus.

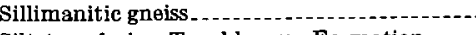
Siltstone facies, Troublesome Formation...... Snails. -

Soils, age

Soricid...

Sphaerium

Split Rock local fauna, middle zone.......... Springs.

Structure

- 61

subundata, Lucina.................... 20

Sundance Formation....................... 13

Superposed folds, trends.....................-

Superpos i tion.

Syenite porphry

Synclines.

$6,22,24,61,66,67$

Talpid -

Tectonism.

Teleostean fishes

Temperature..

Tenea circularis.

sp..

(1) 
Page

tenultneatus, Inoceramus

Terrace deposits............................. 57

Tertiary rocks.................. 5,21

Boulder conglomerate of Gravel Moun-

tain . 6,55

depositionsl environment....... 70

heavy-mineral assemblage............... $\quad \sigma 9$

Middle Park Formation

Pete Gulch Member.................... so so

Rabbit Ears Volcanics.................... 6, 29,70

Thet is circularis

Titanothere............... 46

Topography.

Trachyandesite, Rabbit Ears Volcanics......

Trachyandesite plug, Rabbit Ears Volcanics.

Trachyandesite porphyry -

Travertine.

Triassic rocks, Chugwater Formation

Triatriopollenites sp.......................... 25

Troublesome Creek

Troublesome-Boulder Creek Granodiorite contact.

Troublesome Formation................ 5, 6, 40, 70

ash beds._...

depositions lenvironment.............. 41, 43, 70

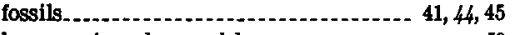

heavy-mineral assemblage............... 69

measured section. siltstone facies.

Page

Troublesome-Grouse Mountain Basalt tect.

Troublesome-Middle Park contact...........

Troublesome-Niobrara contect.

Troublesome-Rabbit Ears contact

Tuff, Rabbit Ears Volcanics.

Tuff breccia, Rabbit Ears Volcanics..........

\section{U}

Undecided prospect, uranium

Uplift

Uranium. .

V

vanuxemi, Inoceramus

Vasquez thrust fault

Vegetation.

Viburnum magnum

Volcanic rocks

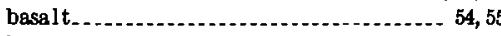

breccia. . . . . . .

breccia of Marietta Creek. ............. 27

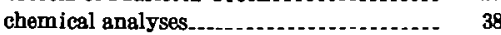

Grouse Mountain Basalt . ............... 59

normative minerals........................ 39

optical properties... 33,36
Page

Pete Gulch Member............

Rabbit Ears Volcanics._............... 29, $\$ 1$

tuff

tuff breccia.............................

Windy Gap Volcanic Member........... 26

Volcanism.

W

White River Group . .

Williams Fork

Williams Range thrust fault

Willow Creek.

Windy Gap Volcanic Member........... 5, 23, 26

depositional environment

heavy-mineral assemblage.................. $\quad 59$

measured section .

woyomingensis, Prionocyclus................. 17

Zones:

Baculites aspertformis compressus. cuneatus.................................. 19, 20 gregoryensis......................... 20, 24, 71 mclearni.............................. 21 perplexus_....................... 24, 20, 21 reesidei.

rugosus................................. 20

scotti 

UNITED STATES DEPARTMENT OF THE INTERIOR
GEOLOGICAL SURVEY
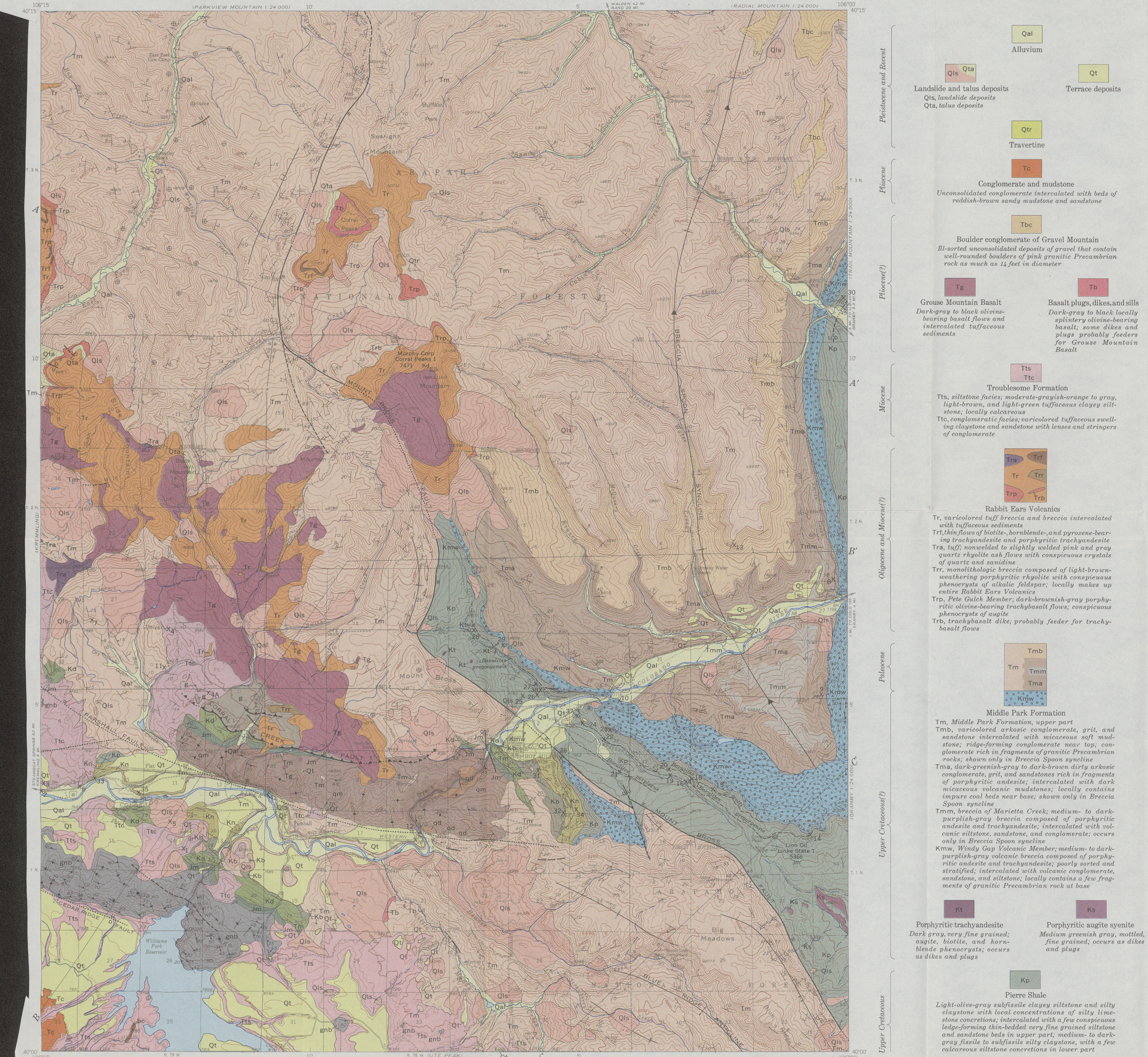

PROFESSIONAL PAPER 586
PLATE 1

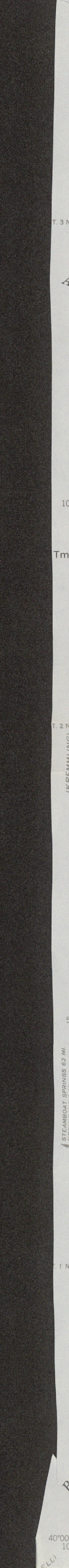

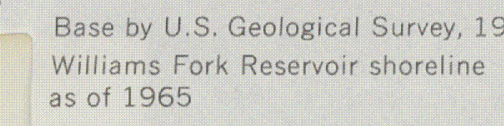

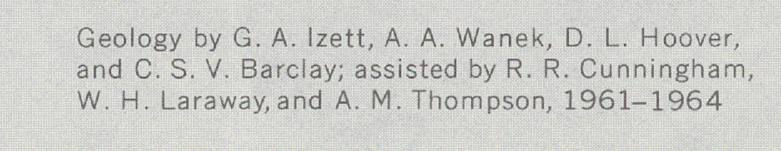
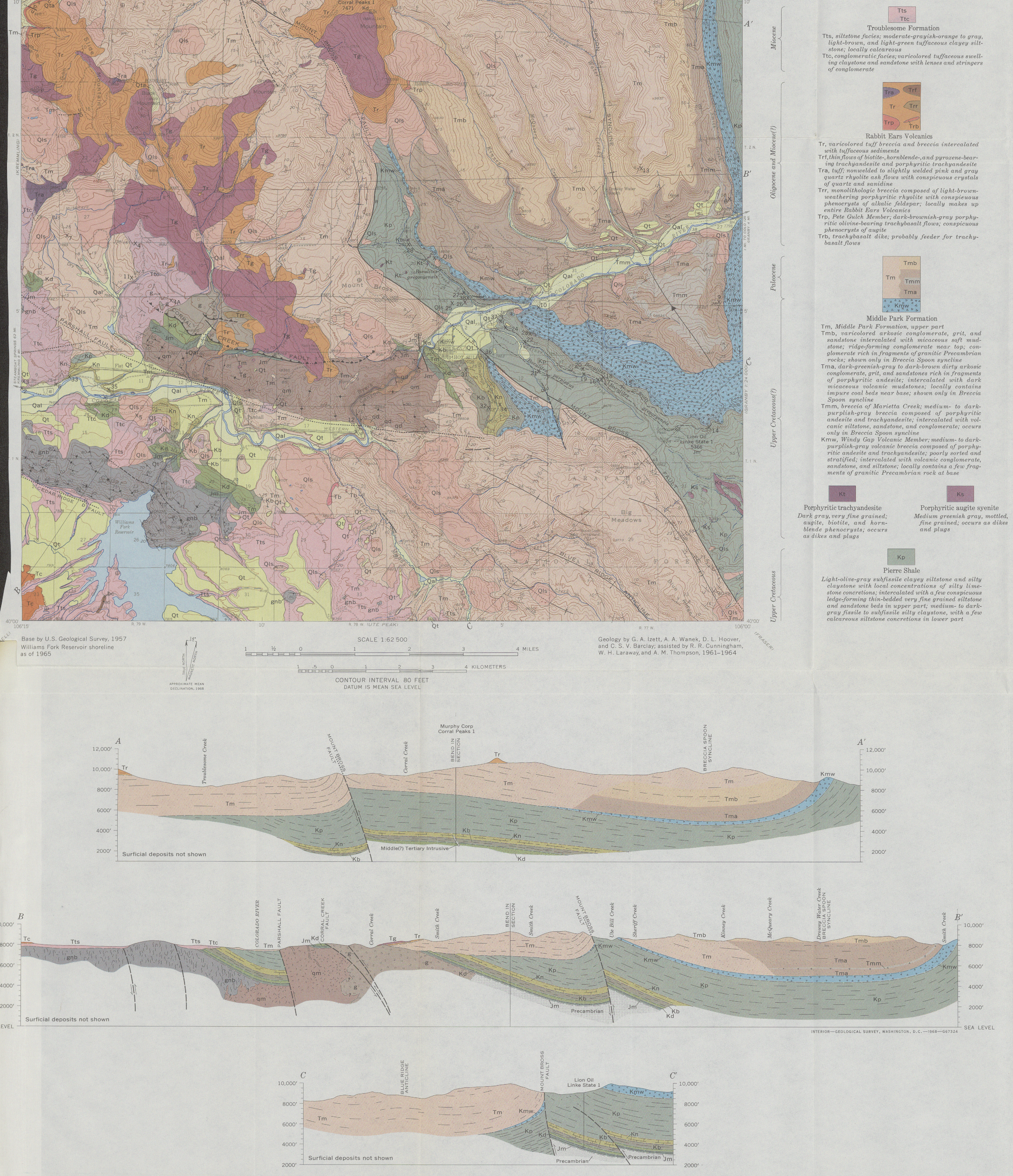

mand

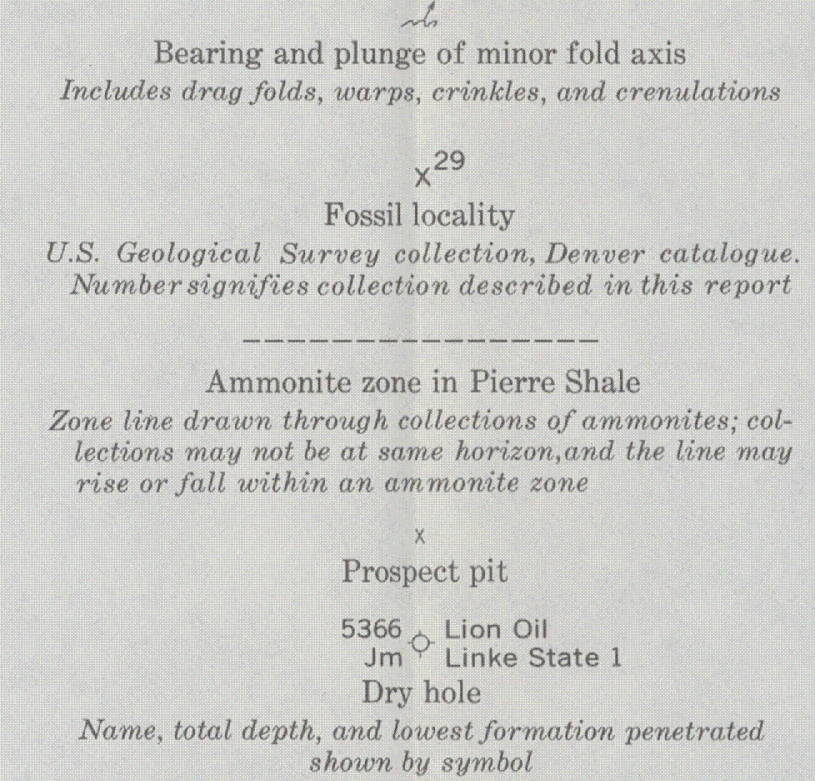


